\title{
Toekomstverkenning: ambities en de praktijk : een etnografische studie naar de productie van toekomstkennis bij het Ruimtelijk Planbureau (RPB)
}

Citation for published version (APA):

van 't Klooster, S. A. (2007). Toekomstverkenning: ambities en de praktijk : een etnografische studie naar de productie van toekomstkennis bij het Ruimtelijk Planbureau (RPB). [Doctoral Thesis, Maastricht University]. Maastricht University. https://doi.org/10.26481/dis.20070622sk

Document status and date:

Published: 01/01/2007

DOI:

10.26481/dis.20070622sk

Document Version:

Publisher's PDF, also known as Version of record

Please check the document version of this publication:

- A submitted manuscript is the version of the article upon submission and before peer-review. There can be important differences between the submitted version and the official published version of record.

People interested in the research are advised to contact the author for the final version of the publication, or visit the DOI to the publisher's website.

- The final author version and the galley proof are versions of the publication after peer review.

- The final published version features the final layout of the paper including the volume, issue and page numbers.

Link to publication

\footnotetext{
General rights rights.

- You may freely distribute the URL identifying the publication in the public portal. please follow below link for the End User Agreement:

www.umlib.nl/taverne-license

Take down policy

If you believe that this document breaches copyright please contact us at:

repository@maastrichtuniversity.nl

providing details and we will investigate your claim.
}

Copyright and moral rights for the publications made accessible in the public portal are retained by the authors and/or other copyright owners and it is a condition of accessing publications that users recognise and abide by the legal requirements associated with these

- Users may download and print one copy of any publication from the public portal for the purpose of private study or research.

- You may not further distribute the material or use it for any profit-making activity or commercial gain

If the publication is distributed under the terms of Article 25fa of the Dutch Copyright Act, indicated by the "Taverne" license above, 


\section{Toekomstverkenning: ambities en de praktijk}

Een etnografische studie naar de productie van toekomstkennis

bij het Ruimtelijk Planbureau (RPB) 
ISBN: 978-90-5972-143-2

Uitgeverij Eburon

Postbus 2867

2601 CW Delft

Tel. 015.2131484 | Fax. 015.2146888

info@eburon.nl | www.eburon.nl

Graphic Design:

Fabiana Toni (FT studio)

W. Buytenwechstraat, 28

3024 BN Rotterdam

Tel . 010.2236640

info@ftstudio.nl | www.ftstudio.nl

Omslag:

Fabiana Toni, Maurizio Scarciglia

(C) 2007 Susan van 't Klooster | Alle rechten voorbehouden. Niets uit deze uitgave mag worden verveelvoudigd, opgeslagen in een geautomatiseerd gegevensbestand, of openbaar gemaakt, in enige vorm of op wijze, hetzij elektronisch, mechanisch, door fotokopieën, opnamen, of op enig andere manier, zonder voorafgaande schriftelijke toestemming van de rechthebbende(n).

(c) 2007 Susan van 't Klooster | All rights reserved. No part of this publication may be reproduced, stored in a retrieval system, or transmitted, in any form or by any means, electronic, mechanical, photocopying, recording, or otherwise, without the prior permission in writing from the proprietor(s). 


\title{
Toekomstverkenning: ambities en de praktijk
}

Een etnografische studie naar de productie van toekomstkennis

bij het Ruimtelijk Planbureau (RPB)

\author{
PROEFSCHRIFT \\ ter verkrijging van de graad van doctor aan de Universiteit Maastricht \\ op gezag van Rector Magnificus prof.mr. G.P.M.F. Mols \\ volgens het besluit van het College van Decanen \\ in het openbaar te verdedigen \\ op vrijdag 22 juni 2007 om 14.00 uur
}

DOOR

Susan A. van 't Klooster 


\section{PROMOTORES}

Prof.drir. M.B.A. van Asselt

Prof.dr.ir. W.E. Bijker

\section{BEOORDELINGSCOMMISSIE}

Prof.dr. E. Homburg (voorzitter)

Prof.dr. R. Hoppe (Universiteit Twente)

Dr. J. Mesman

Prof.dr. P. Schnabel (Sociaal en Cultureel Planbureau)

Prof.dr. R. de Wilde

Dit onderzoek is onderdeel van het onderzoeksproject "Perspectives on uncertainty and risk: An interdisciplinary methodology program on toekomstverkenning". Dit onderzoeksprogramma werd gefinancierd met een NWO Vernieuwingsimpuls (2001-2006) die was toegekend aan dr.ir. Marjolein van Asselt.

The research reported in this book is part of the research project "Perspectives on uncertainty and risk: An interdisciplinary methodology program on toekomstverkenning" and was financially supported by NWO Vernieuwingsimpuls (2001-2006) that was assigned to dr. Marjolein van Asselt. 


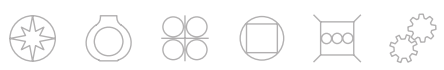




\section{Inhoudsopgave}

\section{Voorwoord}

\section{Afkortingenlijst}<smiles>[131In]</smiles>

14 1. Toekomstverkenning vanuit een nieuwe toekomstoriëntatie

$17 \quad 1.1$ Toekomstverkenning

$22 \quad 1.2$ Twee toekomstverkenningsambities

$27 \quad 1.3$ Toekomstverkenning als object van onderzoek

$30 \quad 1.4$ De toekomstverkennende praktijk bij het Ruimtelijk Planbureau

33 1.5 Drie gevalsstudies

42 2. Een nadere kennismaking

$48 \quad 2.1$ Een relatieve buitenstaander in de praktijk van toekomstverkennen

52 2.2 Een relatieve nieuwkomer in de praktijk van toekomstverkennen

55 2.3 Dataverzameling

592.4 Mijn methodologische bril

80

64 3. De variatieambitie: werken met een assenstelsel

64 3.1 Het assenstelsel als variatie-instrument

683.2 Het assenstelsel als 'skelet' in de SCENE-praktijk

$83 \quad 3.3$ Variatie over variatie

$87 \quad 3.4$ Van variatie naar integratie 
90 4. De integratieambitie: bruggen bouwen en grenzen trekken

914.1 De integratieambitie in de VVR praktijk

1014.2 Integratie van onderzoek en ontwerp

1114.3 Het integratieplan wordt herschreven

113 4.4 Ontwerp sneuvelt

116 4.5 De integratieambities sneuvelen

118 4.6 Van integratie naar variatie

$120 \quad 4.7$ Samenvatting

\section{0}

124 5. Perspectieven op verleden, heden en de toekomst

1255.1 'Tijd' in toekomstverkennen

1275.2 Verschillende temporele repertoires

130 5.3 Tijd' in de WLO-praktijk

1395.4 Het historisch-determinisme wordt dominant

1425.5 Toekomstverkenningen in een 'nieuw' jasje

145 5.6 Samenvatting

150 6. Productie van toekomstkennis

1506.1 Ambities in de praktijk

159 6.2 Suggesties voor toekomstverkenners

162 Referenties

174 Bijlage 1: Overzicht van observatiemomenten

178 English summary

188 Curriculum Vitae Susan van 't Klooster 


\section{Voorwoord}

Onderzoekstrajecten verlopen vaak alles behalve lineair. Dat geldt niet alleen voor de projecten die ik observeerde bij het Ruimtelijk Planbureau, maar ook voor mijn eigen onderzoek. Het is precies om deze reden dat onderzoekers achteraf vaak constateren dat het goed was om een eindproduct te hebben om naar toe te werken, maar dat het de reis was die het meest telde.

De weg die ik de afgelopen vijf jaar aflegde, zou zonder twijfel minder begaanbaar, boeiend en de moeite waard zijn geweest als ik een aantal mensen niet was tegengekomen. Nu ik het eindpunt heb bereikt, is het tijd om even stil te staan, terug te kijken en deze mensen te bedanken.

Wiebe Bijker en Marjolein van Asselt hebben mij de gelegenheid gegeven om mijn fascinatie voor het denken over de toekomst de vrije loop te laten. Ik was gezegend met twee begeleiders die feilloos aanvoelden welke sturing op welk moment nodig was en die sturing ook konden geven. Wiebe, bedankt voor alle inspirerende en coachende gesprekken. Jij wist mijn twijfel en onzekerheid steeds weer in goede banen te leiden. Er is geen overleg geweest dat ik niet na afloop vol nieuwe ideeën of vertrouwen jouw kamer verliet. Marjolein, jij was meer dan je van een (co)promotor zou mogen verwachten: jij was voor mij niet alleen een onuitputtelijke bron van inspiratie en kritische toehoorder, maar ook een psycholoog, een mental coach, een vriendin.... In die acht jaar dat we elkaar kennen en hebben samengewerkt heb jij zowel privé als professioneel veel voor mij betekend. Wiebe en Marjolein, ik ben ontzettend dankbaar dat ik met jullie beiden heb mogen samenwerken.

Ook wil ik mijn oud-collega's bij de Faculteit der Cultuur en Maatschappijwetenschappen en in het bijzonder alle mensen van de vakgroep Maatschappijwetenschap en Techniek en de onderzoeksgroep BOTS bedanken voor het aangename werkklimaat. Ik was de afgelopen jaren omringd door een groep zeer gepassioneerde mensen. Joke, Nicole, Sabine en Jacqueline, bedankt voor jullie professionele en persoonlijke secretariële ondersteuning. Jaap, bedankt voor de gezonde afleiding die je mij bezorgde. Ook dank ik de onderzoeksschool Wetenschap, Technologie en Moderne Cultuur (WTMC) en in het bijzonder de coördinatoren van het opleidingsprogramma voor promovendi Paul Wouters, Annemiek Nelis, Sally Wyatt en Els Rommes. Ik heb ook veel te danken aan mijn collegapromovendi. Bedankt voor alle fijne, gezellige, emotionele, kritische en persoonlijke momenten die ik met jullie heb gedeeld. Ik hoop dat onze wegen elkaar in de toekomst nog vaak zullen kruisen.

Dit onderzoek was niet mogelijk geweest als de mensen bij het RPB niet bereid waren geweest mij een kijkje in hun keuken te gunnen. Wim Derksen, Ed Dammers, Friedel Filius, Hugo Gordijn, Jan Schuur, Lia van den Broek en alle andere betrokkenen bij SCENE, WR en WLO, bedankt voor jullie gastvrijheid en dat jullie mij de ruimte hebben gegeven om jullie dagelijkse praktijk te observeren. Ook dank ik Ruud Okker van het 
Centraal Planbureau en Leon Janssen van het Milieu- en Natuurplanbureau en alle mensen van de afdeling beleidsstudies van het Energieonderzoek Centrum Nederland. Ik hoop jullie met dit proefschrift iets terug te kunnen geven. Ik wil Friedel in het bijzonder bedanken voor haar hulp op een moment dat ik dat heel hard nodig had.

In de zomer van 2005 was ik te gast bij professor Leigh Star en professor Geof Bowker en het Center for Science, Technology and Society aan Santa Clara University (CA, USA). In deze periode heb ik in een inspirerende omgeving een van mijn lastigste hoofdstukken kunnen schrijven. Bedankt dat jullie mij die mogelijkheid hebben gegeven.

Een speciale dank aan Philip van Notten, Sophie Bouwens, mijn zusje Hilde en mijn moeder voor het lezen en becommentariëren van het manuscript.

Mijn ouders, familie en vrienden wil ik bedanken voor hun belangstelling en ondersteuning in welke vorm dan ook.

Ik draag dit boek op aan de twee mannen in mijn leven. Lieve Jeroen, bedankt voor je grenzeloze vertrouwen, je eindeloze geduld en je altijd positieve instelling. Thijsje, bedankt dat je in ons leven bent gekomen. Zonder het zelf te weten plaats je alles steeds weer in het juiste perspectief. Jullie maken mijn wereld zo veel mooier! 


\section{Afkortingenlijst}

ATV Algemene Toekomstverkenning

AW Algemene Verkeer- en Vervoerdienst

BTV Beleidsgerichte Toekomstverkenning

BZK Ministerie van Binnenlandse Zaken en Koninkrijksrelaties

CBS Centraal Bureau voor de Statistiek

CPB Centraal Planbureau

ECN Energieonderzoek Centrum Nederland

EEA European Environmental Agency

EFO Economie en Fysieke Omgeving

IA Integrated Assessment

IFTF Institute for the Future

IPCC Intergovernmental Panel on Climate Change

KAN Knooppunt Arnhem - Nijmegen

KUN Katholieke Universiteit Nijmegen (nu Radboud Universiteit Nijmegen)

LEI Landbouw Economisch Instituut

MNP Milieu- en Natuurplanbureau

RIKZ Rijksdienst voor Kust en Zee

RIVM Rijksinstituut voor Volksgezondheid en Milieu

RIZA Rijksdienst voor Zoetwaterbeheer en Afvalwaterbehandeling

RMNO Raad voor Ruimtelijk, Milieu- en Natuuronderzoek

RNP Rijksdienst voor het Nationale Plan

RPB Ruimtelijk Planbureau

RPD Rijksplanologische Dienst

SCENE SCEnario's voor NEderland

SCP Sociaal en Cultureel Planbureau

STS Science Technology and Society

SSK Sociology of Scientific Knowledge

TNO Nederlandse Organisatie voor Toegepast Natuurwetenschappelijk Onderzoek

TK Tweede Kamer

VROM Ministerie van Volkshuisvesting, Ruimtelijke Ordening en Milieubeheer

WR Verkenning van de Ruimte

V\&W Ministerie van Verkeer \& Waterstaat

WLO Welvaart en Leefomgeving

WNF Wereld Natuurfonds

WRR Wetenschappelijk Raad voor het Regeringsbeleid

WTMC Nederlandse onderzoeksschool voor Wetenschap, Technologie en Moderne Cultuur 
2

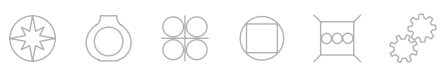


"No matter how inclusive the information-gathering efforts, how effective the analytic tools and techniques, how profound our insights, and how careful the resulting preparations, the future is certain to follow paths and offer events we did not imagine" (Lempert, Popper, \& Bankes, 2003). 


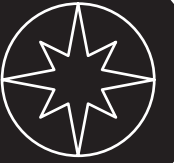

(0)
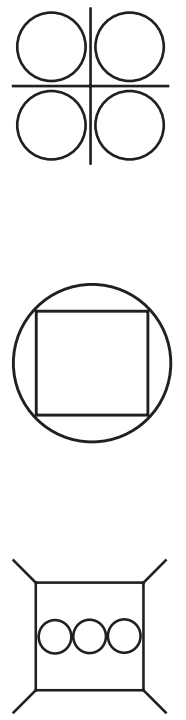

 


\section{(1) Toekomstverkenning vanuit een nieuwe toekomstoriëntatie}

Hoe kunnen we Nederland beschermen tegen overstromingen als ons klimaat verandert? Hoe veel, waar en wat voor type huizen en woonwijken moeten we bouwen voor de toekomst? En hebben we een extra spoorwegverbinding nodig tussen de Randstad en het hoge Noorden? Elk van deze complexe beleidskwesties vraagt om een visie op de lange termijn.

In Nederland houden veel experts zich bezig met hoe de toekomst van ons land eruit zou kunnen zien. Door op systematische wijze kennis over de toekomst te produceren trachten zij beleidsmakers in het maken van deze complexe keuzes te ondersteunen. Toekomstverkenning is in Nederland een geïnstitutionaliseerde praktijk. Dit betekent dat er in Nederland instituten zijn die zichzelf de taak hebben gesteld of vanuit de overheid de taak hebben gekregen de Nederlandse toekomst te verkennen (van Asselt, 2003). Al in 1987 spraken van der Staal \& van Vught (1987) over toekomstverkennen als 'een geïnstitutionaliseerd (..) overheidsapparaat voor het verkennen van de Nederlandse toekomst' en van 'een gespecialiseerde groep toekomstvorsers' (van Vught, 1985). Toekomstverkenningen zijn voor het Nederlandse beleid een factor van betekenis geworden en niet meer weg te denken uit onze besluitvormingscultuur (Halffman \& Hoppe, forthcoming). Toekomstverkenningen zijn een onderdeel van het proces van beleidsontwikkeling in Nederland voor tal van deelterreinen.

Toekomstverkenners bevinden zich echter in een spanningsveld. Enerzijds is er de ambitie om op systematische wijze inzichten te genereren over de toekomst. Anderzijds is er het besef dat de toekomst per definitie niet te kennen is. Uitspraken over de toekomst kunnen niet empirisch worden getoetst in de klassiek wetenschappelijke zin, want de toekomst bestaat nu eenmaal niet. Dit spanningsveld wordt groter naargelang de complexiteit en het bereik van de toekomstverkenning toeneemt: hoe meer schaalniveaus en onderwerpen over een langere tijdsperiode worden meegenomen, des te moeilijker het wordt om op systematische wijze inzichten te genereren. Het verkennen van de toekomst lijkt daarom een onmogelijke opgave, want: "How can we study and make justified statements about that which does not exist?" (Bell, 2000: 148). De toekomst is een nog niet bestaande werkelijkheid die omgeven is met grote onzekerheid: zowel de verschijningsvorm van de toekomst als de dynamiek van de verandering die daaraan ten grondslag ligt, zijn onbekend en vaak onkenbaar (Bovens \& , t Hart, 1996). Toekomstverkenning lijkt daarom een 'mission impossible'.

Toch verschijnen er met grote regelmaat toekomstverkenningen, waarin op basis van een systematische analyse uitspraken worden gedaan over wenselijke, (on)mogelijke en/of waarschijnlijke toekomsten teneinde richting te geven aan huidig en toekomstig handelen. Alleen al in Nederland verschenen in de periode 1997 - 2005 zo'n 150 tot 200 toekomstverkenningen in het publieke domein ${ }^{1}$ (nog afgezien van toekomstverkenningen

\footnotetext{
${ }^{1}$ Dit aantal is afhankelijk van welke definitie van toekomstverkenning wordt gehanteerd. In deze
} 


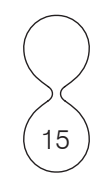

die niet gepubliceerd / uitgegeven worden) (van Asselt, de Wilde, van der Pas, Wolthuis, et al. 2005)². Dus, hoewel de toekomst ongekend en onkenbaar is, lijken toekomstverkenners manieren gevonden te hebben om vooruit te kijken en orde te creëren in complexiteit. In dit onderzoek beoog ik meer inzicht te krijgen in de manier waarop toekomstverkenners dat doen en te achterhalen hoe zij kennis produceren over de toekomst. Toekomstverkennen betekent balanceren tussen kennen met relatieve zekerheid en verkennen in totale onzekerheid. Hoe vinden toekomstverkenners deze balans? Enerzijds kunnen zij op basis van expertise, empirische kennis en gedegen onderzoek naar causale mechanismen uitspraken doen over mogelijke en zelfs waarschijnlijke toekomsten. Anderzijds zijn mensen die vooruit willen kijken niet in stabiliteit, maar in verandering geïnteresseerd. Toekomstverkenners zeggen vaak verder te willen gaan dan "meer van hetzelfde" of zogenaamde "business-as-usual"toekomsten. Er komt dus een punt dat zij (relatieve) zekerheden moeten loslaten en moeten verkennen in onzekerheid. Hoe volbrengen toekomstverkenners deze schijnbaar onmogelijke opgave? Hoe creëren toekomstverkenners orde in complexiteit? Hoe brengen zij structuur aan? Hoe balanceren zij tussen zekerheid en onzekerheid, tussen het waarschijnlijke en het (on)mogelijke, het bekende en het radicaal nieuwe?

In dit proefschrift wil ik beschrijven en analyseren hoe 'toekomstkennis' wordt geproduceerd. Het woord 'toekomstkennis' is strikt genomen een contradictio in terminis (zie ook de Jouvenel (1963: 5)) omdat de toekomst ten principale onkenbaar en ongekend is. Deze schijnbare paradox die ten grondslag lijkt te liggen aan het verkennen van de toekomst is ook treffend verwoord door Reichenbach (1951): "A statement about the future cannot be uttered with the claim that it is true; we can always imagine that the contrary will happen, and we have no guarantee that future experience will not present to us as real what is imagination today" (241). De constructivistische turn in de wetenschap heeft echter laten zien dat kennis meer is dan feiten, die door wetenschappelijke experts worden 'ontdekt' (Kuhn, 1970)․․ Wanneer ik het woord 'toekomstkennis' gebruik, dan

studie zijn zowel toekomstverkenningen waarin meer of minder onderbouwde en/of systematische uitspraken worden gedaan over de toekomst als meer essayistische beschouwingen (waarin ideeën over de toekomst verpakt zitten of verbeeld worden) meegenomen. Zogenaamde "diagnoses van tijd", waarin structurele ontwikkelingen in heden en verleden worden geduid en waarin een aantal thema's of ontwikkelingen geagendeerd worden zijn niet in de analyse meegenomen.

${ }^{2}$ Zie ook www.toekomstverkenning.nl.

${ }^{3}$ Mijn onderzoek bouwt voort op een lange constructivistische traditie. Met de publicatie van het boek The Structure of Scientific Revolutions (1970) ontstond een wetenschappelijke stroming die bekend werd onder de naam 'Sociology of Scientific Knowledge' (SSK). Het startpunt van SSKstudies was een sociaal constructivistisch wetenschapsperspectief. Dit betekent dat werd afgestapt van het idee dat wetenschappelijke kennis kan worden verkregen op basis van puur rationele, cognitieve factoren. Ten grondslag aan dit wetenschapsperspectief ligt de idee dat rationaliteit en criteria voor het onderscheiden van valide en niet-valide wetenschappelijke stellingen niet 
hanteer ik dus een brede definitie van het begrip 'kennis' en verwijs ik naar het totaal door toekomstverkenners geproduceerde inzichten over de toekomst.

In mijn proefschrift reconstrueer ik wat de toekomstverkenners construeren. In plaats van nadrukkelijk bij te dragen aan het constructieproces, reflecteer ik op het proces van toekomstverkennen. Mijn verhalen over de praktijk zijn sterk empirisch gegrond: ik had mijn verhaal dus nooit kunnen vertellen zonder getuige te zijn geweest van de verhalen die de toekomstverkenners zelf over de toekomst en over hun praktijk vertelden. Mijn verhaal is dus anders dan het verhaal van de door mij geobserveerde toekomstverkenners, of beter gezegd: de verhalen van de verschillende toekomstverkenners. Als ik een lunchlezing geef voor toekomstverkenners, dan word ik niet gezien als een van hen. Door mijn positie als relatieve buitenstaander vertel ik een ander verhaal. Ik heb niet alleen een ander perspectief, ook een ander vocabulaire en (deels) een ander publiek.

Met dit boek richt mij tot collega-onderzoekers die zich bezighouden met praktijken van (toekomst)kennisproductie. Aan deze lezers wil ik de wereld der toekomstverkenners ontsluiten en inzichten aandragen over de manier waarop (in deze praktijk) (toekomst)kennis wordt geproduceerd.

Daarnaast hoop ik nieuwe inzichten te bieden aan mensen die in de praktijk bij de productie van toekomstkennis betrokken zijn en degenen die reflecteren op het gebruik van methoden en technieken van toekomstverkennen. Ik beoog met dit proefschrift uitdrukkelijk niet om te besluiten met "de" methode, "de" panacee voor toekomstverkenningen. Mijn intentie is, met andere woorden, niet om een handboek te schrijven voor het doen van toekomstverkenningen. De boodschap in dit boek is ook niet dat het vervolmaken van methoden zal leiden tot een beter gebruik van toekomstverkenningen. Wel zal ik een aantal spanningen en tegenstrijdigheden blootleggen in de hedendaagse praktijk van toekomstverkenning en suggesties doen hoe hiermee om te gaan. Ik wil toekomstverkenners een spiegel voorhouden en laten nadenken over hun handelingsperspectief en de consequenties daarvan voor de manier waarop de toekomst wordt verkend. Ik hoop dat toekomstverkenners hun voordeel hiermee kunnen doen.

kunnen worden afgeleid van een 'abstract and universal faculty of reason' (Hess, 1995), maar dat zowel rationaliteit als criteria van wetenschap worden gedefinieerd door het perspectief van een bepaalde discipline en/of wetenschappelijke gemeenschap. Het uitgangspunt daarbij is dat kennis het resultaat is van interacties tussen wetenschapsbeoefenaars en hun omgeving en dus dat wetenschappers niet de waarheid 'ontdekken', maar (sociaal) 'construeren'. Zie ook o.a. Bijker, Hughes, \& Pinch (1987); Bijker (1995); de Vries (1995); Jasanoff, Markle, Petersen, \& Pinch (1995); Hagendijk (1996) en Latour \& Woolgar (1979). 
Ook schrijf ik dit boek voor mensen die te maken hebben met het formuleren van lange termijn beleid en die toekomstkennis gebruiken als bron van informatie of inspiratie, zoals politici en beleidsmakers. Aan deze lezers wil ik inzichten en voorbeelden aandragen over processen die een rol lijken te spelen bij het totstandkomen van beleidsgerichte (toekomst)kennis. Door een nieuw licht te werpen op de praktijk van toekomstverkennen hoop ik bij te dragen aan een beter geïnformeerd gebruik van toekomstkennis. En ik richt mij tot mensen die in meer algemene zin werken of op een andere manier betrokken zijn bij hybride organisaties in de interface tussen wetenschap, beleid en maatschappij. Ik denk dan bijvoorbeeld aan de sectorraden en de adviesraden, en dan in het bijzonder de RMNO en VROM-raad die zich, net als het Ruimtelijk Planbureau, bezig houden met het reflecteren op de ruimtelijke ordening van Nederland in een lange termijn perspectief.

In dit proefschrift beschrijf en analyseer ik wat toekomstverkenners 'doen' als zij de toekomst verkennen. Ik wil niet nut en noodzaak van toekomstverkennen ter discussie stellen. Ik wil niet beoordelen of evalueren, maar begrijpen hoe toekomstverkenners in staat zijn zoiets schijnbaar onmogelijks als het produceren van toekomstkennis te volbrengen. Het object van onderzoek zijn de activiteiten van toekomstverkenners die een glimp op willen vangen van hoe de toekomst er uit zou kunnen zien.

\section{$1.1 \quad$ Toekomstverkenning}

Het nadenken over en anticiperen op de toekomst is van alle tijden (Helmer, 1983); (Bell, 2000); (van Asselt, van ,t Klooster, \& van Notten, 2003). Het denken over de toekomst is namelijk essentieel voor menselijk handelen: zonder het bewustzijn van tijd zouden zelfs de eerste vormen van landbouw niet mogelijk zijn geweest, want om te kunnen oogsten moet eerst grond worden bewerkt en bezaaid. Bedrijven van landbouw, hoe primitief ook, vereist dat in het heden, lerend van het verleden, op de toekomst wordt geanticipeerd.

Er zijn veel verschillende soorten toekomstverkenningen. In feite zouden we ook uitspraken van waarzeggers, profetieën, utopische vertellingen en 'science fiction'verhalen onder het kopje toekomstverkenning kunnen scharen. Dat doe ik niet. Als ik in dit proefschrift spreek over toekomstverkenning(en), dan heb ik het over professionals die werken bij serieuze organisaties en over pogingen, die, door de toekomstverkenners zelf of hun publiek, vaak geportretteerd worden als zijnde "wetenschappelijk".

Het systematisch verkennen van de toekomst, waarbij gebruik wordt gemaakt van wetenschappelijke methoden, is een relatief nieuw fenomeen. Van der Staal \& van Vught (1987) lokaliseren de 'geboorte' van systematische toekomstverkenningen aan het begin van de $20^{\text {ste }}$ eeuw. Als ijkpunt verwijzen zij naar het artikel 'The Discovery of the Future' van Wells, dat nu meer dan een eeuw geleden in Nature verscheen, en waarin hij de 
potenties van de "toekomstkunde" als een vorm van wetenschap schetste. Hoewel Wells erkende dat de absolute waarheid niet gevonden zou kunnen worden, geloofde hij dat een "working knowledge of things in the future" binnen handbereik was (Wells, 1902).

Systematische toekomstverkenning wordt ingezet in heel verschillende toepassingsdomeinen, zoals het maatschappelijke domein (zoals toekomstverkenningen van het Wereld Natuurfonds (WNF, 1999), het bedrijfsleven (Essent N.V., 2004) en de academische wereld (bijvoorbeeld toekomstverkenningen die worden ontwikkeld door het Intergovernmental Panel on Climate Change (IPCC, 1990; 1996). In dit proefschrift richt ik mij op beleidsgerichte toekomstverkenningen, namelijk die toekomstverkenningen die zich richten op het ondersteunen van beleidsontwikkeling en besluitvorming door (Nederlandse) beleidsmakers en in het bijzonder de nationale overheid. Hieronder zal ik in vogelvlucht beschrijven hoe de praktijk van beleidsgericht toekomstverkennen zich sinds het begin van de vorige eeuw in Nederland heeft ontwikkeld.

\section{'De toekomst' aan het begin van de 20ste eeuw}

In Nederland was aan het begin van de vorige eeuw van beleidsgericht verkennen van de toekomst nauwelijks sprake. Het overheidsbeleid richtte zich in deze periode voornamelijk op de regulering van ontwikkelingen die zich feitelijk al hadden voorgedaan. Maatschappelijke problemen werden in deze periode voornamelijk 'topdown' aangepakt: de centrale overheid zette de grote lijnen uit en de provincies vertaalden deze door naar het laagste schaalniveau. Daarbij werd maar zeer beperkt rekening gehouden met maatschappelijke wensen en verwachtingen. Op basis van gedegen analyses van processen en trends werden door onderzoekers in dienst van de overheid studies gedaan van hoe Nederland er uit moest gaan zien en die met name waren gericht op het oplossen van problemen in het heden en op de korte termijn. Met deze studies in de hand probeerde de overheid de maatschappelijke werkelijkheid planmatig naar zijn hand te zetten (van der Cammen \& de Klerk, 2003).

Wanneer men in deze periode over de toekomst nadacht, dan deed men dat vanuit een sterk geloof in vooruitgang. De snelle opeenvolging van nieuwe technologische ontdekkingen, zoals de telefoon, de radio en de auto, ontketende in deze periode hooggespannen verwachtingen van de rol van de techniek. En dit ging gepaard met een sterk geloof in de maakbaarheid en voorspelbaarheid van de samenleving. Kenmerkend voor deze periode zijn bijvoorbeeld de discussies rondom de drooglegging van de Wieringermeer in de Zuiderzee. Ester, Geurts, \& Vermeulen (1997) citeren in dit verband de Amsterdams hoogleraar sociografie/sociologie ter Veen die in de jaren dertig betrokken was bij onderzoek en advies rond sociale vraagstellingen rondom de drooglegging, die stelde: "Hier moet gebouwd worden aan een nieuwe samenleving" (14). Ook in het werk van bijvoorbeeld de stedenbouwkundige van Lohuizen weerklinkt 
dit rotsvaste vertrouwen in objectieve wetmatigheden: "Achter het steeds veranderende leven staat een hogere wettelijkheid, die de onderzoeker telkenmale achter de schijnbaar dorre cijfers tevoorschijn ziet komen. Het bestaan hiervan geeft hem het vertrouwen in de waarde van zijn werk" (van Lohuizen, 1940); zie ook van Lohuizen (1948).

\section{'De toekomst' wordt object van onderzoek}

Binnen een context van toenemende onzekerheden die voortkwamen uit de verdere individualisering en "onttovering" van het leven (de Wilde, 2000) groeide de behoefte aan meer flexibele plannen en visies die meer gericht waren op de lange termijn. In deze periode ontstonden nieuwe toekomstoriëntaties, waarin de nadruk meer kwam te liggen op het toekomstonderzoek. Nio (2003) laat bijvoorbeeld zien hoe daarmee ook de status van het beleidsgerichte onderzoek in Nederland, in het bijzonder op het terrein van de ruimtelijke ordening, veranderde: "In plaats van dat op grond van (..) onderzoek vooraf werd bepaald welke functies in het ontwerp moesten worden meegenomen, werden nu vanuit het (onderzoekend) ontwerpen de mogelijkheden en beperkingen van een gebied verkend" (6). Van der Cammen \& de Klerk (2003) beschrijven hoe in deze periode een einde kwam aan de oorspronkelijke planningambitie die was gericht op het organiseren en vormgeven van de Nederlandse samenleving. Kenmerkend voor het toekomstgerichte onderzoek werd het opsporen en doorgronden van verbanden tussen sociale, economische en andere maatschappelijke ontwikkelingen. Planning werd vanaf deze periode gebruikt als middel om ontwikkelingen in de goede richting te stuwen. Het idee was dat door verschillende lange termijn ontwikkelingen in overweging te nemen voorspellende uitspraken gedaan zouden kunnen worden over de toekomstige samenleving.

Een belangrijke publicatie uit deze periode is The Year 2000. A Framework for Speculation on the Next Thirty-Three Years van Kahn en Wiener (1967), waarin het belang van toekomstgericht denken en handelen en de mogelijkheid te komen tot een betere toekomst onderstreept werden. Dit boek is één van de eerste publicaties waarin werd geprobeerd de toekomst op systematische, op wetenschap gebaseerde wijze te bestuderen. Een andere toonaangevende publicatie die in deze context vaak aangehaald wordt, is het eerste rapport van de Club van Rome Limits to Growth (Meadows, Meadows, Randers, \& Behrens, 1972) dat de alarmerende boodschap uitdroeg dat met voortzetting van het huidige beleid binnen honderd jaar de grenzen aan de groei op onze planeet zouden zijn bereikt. Dit toekomstgeoriënteerde rapport voorspelde het opraken van onze energiebronnen en ontwrichtende milieuproblemen. In dit werk bekritiseerde de Club van Rome het vanzelfsprekende denken in termen van vooruitgang. Andere invloedrijke publicaties in die periode waren ondere andere Inventing the Future van Gabor (1964) en The Art of Conjecture (1967) van de Jouvenel (1967). Met name Gabor waarschuwde voor mogelijke maatschappelijke catastrofes die zich zouden 
kunnen voordoen. Toch had zijn werk een optimistische ondertoon, omdat hij een groot vertrouwen uitsprak in de mogelijkheden het tij te keren. Een laatste invloedrijke persoon die in dit riitje niet mag ontbreken was Toffler die in 1970 het boek Future Shock (Toffler, 1970) en in 1981 The Third Wave (Toffler, 1981) publiceerde. Hij benadrukte in zijn werk vooral het belang van het schetsen van een in eerste instantie huiveringwekkend perspectief, maar biedt uiteindelijk toch geruststellende verhalen over de toekomst te bieden (vergl. de Wilde (2000)).

Deze en andere publicaties trokken internationaal veel aandacht en droegen bij aan het besef dat complexe fundamentele beleidskwesties vragen om toekomstverkenning. Er heerste in deze periode een groot vertrouwen in de wetenschappelijke mogelijkheden de maatschappij vanuit een vogelvluchtperspectief in zijn geheel te kunnen overzien. Zowel wetenschappers als beleidsmakers geloofden dat een 'single perception providing a comprehensive vision of the whole issue' mogelijk moest zijn (Dresen, 2003); vergl. Jasanoff \& Wynne (1998). Vanuit dit wetenschappelijke optimisme over de kenbaarheid van de samenleving werden er nieuwe planningtechnieken ontwikkeld, zoals het maken van prognoses ${ }^{4}$ en projecties. Eén van de studies waarin aandacht werd besteed aan deze statistische technieken van toekomstonderzoek is het boek Looking forward: A guide to Futures Research van Helmer uit 1983. Hij signaleerde een "growing awareness that a great deal can be said about future trends in terms of probability and, moreover, that through proper planning we can exert considerable influence over these probabilities" (Helmer, 1983: 17). Helmer geloofde dat door perfectionering van mathematische modellen de toekomst uiteindelijk gekend en voorspeld kon worden. De toekomstgerichte studies uit deze tijd kenmerkten zich door een min of meer 'verrassingsvrije' aanpak en veronderstelden een continuïteit van ontwikkelingen uit het verleden via het heden naar de toekomst (van der Duin, Hazeu, Rademaker, \& Schooneboom, 2004) $)^{5}$.

In Nederland kreeg, mede onder invloed van het rapport van de Club van Rome (Meadows, Meadows, Randers, \& Behrens, 1972), de in 1972 opgerichte Wetenschappelijke Raad voor het Regeringsbeleid (WRR) expliciet de taak

\footnotetext{
${ }^{4}$ Een prognose is een manier waarop toekomstverkenners uitspraken doen over de toekomst, namelijk als een puntschatting (eventueel met een bandbreedte) die gebaseerd is op extrapolatie van trends zoals die in het verleden hebben voorgedaan. Deze manier van toekomstverkenning gebruikt in het algemeen statistiek als basis om uitspraken te doen over de toekomst. Toekomstverkenners zeggen door middel van prognoses uitspraken te kunnen doen over "wat de meest waarschijnlijke toekomst is" (CBS/RIVM, 2004: 13). De onderliggende aannames is dat er geen wezenlijk andere processen een rol zullen spelen in de toekomst, dat de belangrijkste mechanismen voldoende begrepen zijn en dat zich geen discontinuïteiten (trendbreuken, verrassingen, structurele omwentelingen, zie van Notten (2005)) zullen voordoen.

${ }^{5}$ Zie ook van der Staal \& van Vught (1988) die dezelfde conclusie trokken over de WRR.
} 
toekomstverkenningen uit te voeren en "toekomstonderzoek binnen en buiten de overheid te verbeteren, te bevorderen en te coördineren" (Koninklijk Besluit, 6 november 1972). In 1977 publiceerde de WRR De komende 25 jaar: Een toekomstverkenning voor Nederland, ook wel aangeduid als ATV - Algemene Toekomstverkenning. En in 1980 en 1983 verschenen rapporten aan de regering onder de noemer Beleidsgerichte toekomstverkenning (BTV). Ook de planbureaus en planbureauachtige instituten brachten in deze periode hun eerste toekomstverkenningen uit. In 1975 publiceerde de Rijksplanologische Dienst (RPD) de studie Scenario's ten behoeve van de verstedelijkingsnota (RPD, 1975). Zowel het Centraal Planbureau (CPB, 1985) als het Sociaal en Cultureel Planbureau kwamen in 1985 met hun eerste lange termijnverkenning en in 1988 verscheen de eerste Milieuverkenning van het RIVM met de titel Zorgen voor Morgen (RIVM, 1988). Het Energieonderzoek Centrum Nederland (ECN) bracht in 1987 de eerste Energieverkenningen (ECN, 1987) uit waarin de ontwikkelingen in de Nederlandse sector voor de komende 20 tot 25 jaar werden verkend. Sindsdien produceren deze instituten op reguliere basis rapporten waarin toekomstige ontwikkelingen op de verschillende deelterreinen worden verkend.

\section{Een nieuwe toekomstorientatie: van voorspellen naar verkennen}

De ontwikkeling van methoden van toekomstverkenning vanaf de het begin van de vorige eeuw tot nu laat een verschuiving zien van voorspellende naar verkennende toekomstverkenningen (al worden, zoals ik in dit proefschrift ook zal laten zien, voorspellende methoden nog wel steeds gebruikt). In de loop der jaren is het idee van oncontroleerbaarheid en onvoorspelbaarheid van de samenleving steeds centraler komen te staan. Onder praktiserende toekomstverkenners groeide het besef dat kennis over de toekomst per definitie onvolkomen is en dat het willen voorspellen van de toekomst onmogelijk en zelfs onwenselijk is.

Veel hedendaagse toekomstverkenners nemen expliciet afstand van de oude, voorspellende traditie. De auteurs van de Nationale Milieuverkenning 5 stellen bijvoorbeeld dat "een milieuverkenning is per definitie geen voorspelling van de toekomst" (RIVM, 2000); de verkenners bij het Ruimtelijk Planbureau dat "het gaat over kansen op mogelijk toekomstig ruimtegebruik, niet om voorspellingen" (RPB, 2002), de projectleiders van Nederland 2030 (een studie van de Ruimtelijke Planologische Dienst) dat "de toekomstverkenning Nederland 2030 is geen voorspelling" (de Jong, 1997) en de auteurs van de scenariostudie Scanning the Future dat "contemporary LT (long term, sk) studies do not pretent to predict the future course of history" (CPB, 1992: 32). Het afstand nemen van de 'oude' traditie komt ook tot uitdrukking in de manier waarop de Nederlandse planbureaus zich internationaal positioneren. Het instituut "planbureau" 
wordt in het algemeen geassocieerd met de 'oude' (plannings)traditie ${ }^{6}$. Internationaal presenteert het Milieu- en Natuurplanbureau (MNP) zich niet als "planbureau", maar staat dit instituut bekend als het 'Netherlands Environment Assessment Agency, het CPB als het 'Netherlands Bureau for Economic Policy Analysis' en het RPB als 'Netherlands Institute for Spatial Research'. Alleen het SCP positioneert zich internationaal ook als 'Planning Office'. Het woord planbureau is dus grotendeels verdwenen, waarmee deze organisaties afstand lijken te nemen van de oorspronkelijke voorspellende traditie.

De manier waarop deze toekomstverkenners hun toekomstverkenningen positioneren lijkt het beeld op te roepen dat we momenteel te maken hebben met een andere praktijk van toekomstverkennen. Zo spreken de auteurs van de studie Terugblik op Toekomstverkenningen (WRR, 2000) van een "nieuwe 'generatie' toekomstverkenningen" (13) en het Centraal Planbureau spreekt over "this new category" toekomstverkenningen (CPB, 1992: 34). De 'oude' en 'nieuwe' generatie staan voor een fundamenteel ander idee over de kenbaarheid van de samenleving: de eerste gaat ervan uit dat de toekomst kan worden voorspeld en dat de samenleving maakbaar is; de tweede generatie stelt dat voorspellen een illusie is en dat onzekerheid en complexiteit troef zijn.

\section{$1.2 \quad$ Twee toekomstverkenningsambities}

In 'nieuwe' generatie toekomstverkenningen zijn onzekerheid en complexiteit centrale noties. Het besef dat de toekomst is omgeven met onzekerheid vertalen toekomstverkenners in de praktijk naar wat ik de 'variatieambitie' noem. De toekomstverkenners proberen in hun toekomstverkenningen - om recht te doen aan onzekerheid - verschillende perspectieven op de toekomst te doordenken. Dit in tegenstelling tot meer 'voorspellende studies' waarin de toekomst meestal wordt weergegeven als een puntschatting (eventueel met bandbreedte) en waarin dus niet meerdere perspectieven, maar alleen het perspectief dat vanuit historisch oogpunt het meest waarschijnlijk is in overweging wordt genomen.

Het besef dat de hedendaagse samenleving complexer is dan ooit tevoren vertalen toekomstverkenners naar de ambitie verschillende thema's, disciplines en perspectieven te integreren. Dit noem ik de 'integratieambitie'. De inzet is hier niet, door verschillende

\footnotetext{
${ }^{6}$ Dat in het Nederlands nog steeds de naam 'planbureau' wordt gebruikt, ook voor nieuwe instituten als het Ruimtelijk Planbureau (sinds 1 januari 2002) en het Milieu- en Natuurplanbureau (sinds 1 januari 2006), komt door een besluit in 1995 van de toenmalige minister van VROM (de Boer). Zij voerde aan dat de naam 'planbureau' nu eenmaal in Nederland is ingeburgerd en zij benadrukte daarnaast dat het belang van behoud van analogie met de andere planbureaus (het CPB en het SCP).
} 
relevante aspecten met elkaar in verband te brengen, de toekomst te kunnen voorspellen, maar om nieuwe, slimme combinaties en inzichten over de toekomst op het spoor te komen die, vanuit een meer sectoraal of disciplinair perspectief, uit het zicht van de toekomstverkenner zouden zijn gebleven.

Vanuit dit besef van onzekerheid en complexiteit richten deze toekomstverkenners zich niet alleen op "het weten", maar ook op het "niet weten", niet alleen op wat waarschijnlijk is, maar ook op wat (on)mogelijke is en niet alleen op het 'oude' bekende, maar ook op onbekende nieuwe. Daarbij gaat het niet alleen om het signaleren van trends in verleden en heden, het bepalen van hoe deze trends samenhangen en welke mogelijke impacts deze trends kunnen hebben, maar willen toekomstverkenners verder te gaan dan wat op basis van geobserveerde trends in verleden en heden over de toekomst kan worden gezegd.

\section{De variatieambitie}

Zowel in de praktijk van toekomstverkennen als in de literatuur wordt het interpreteren van onzekerheden veelal gezien als een essentieel onderdeel van een toekomstverkenning. Zo stelt Armstrong in zijn boek Principles of Forecasting bijvoorbeeld dat: "Decision makers need forecasts only if there is uncertainty about the future" (Armstrong, 2001: 2). En van der Duin, Hazeu, Rademaker, \& Schooneboom (2006) stellen dat: ".. the idea of having the future in one's palm, be it even such a little bit, appears once more to have receded far away" (245) en dat tegenwoordig "most futures studies focus on surveying potential futures. In general, they are more conditional (..)" (239).

Ook veel praktiserende toekomstverkenners benadrukken dat er onzekerheden besloten liggen in het toekomstonderzoek. Zo las ik bijvoorbeeld in rapport Scanning the Future (CPB, 1992: 34) dat "The need to reflect on LT (long term, sk) developments appears to be just as unmistakable as the uncertainty it generates" en in Nederland in Drievoud dat "om de beleidsopgaven, en de onzekerheden die daarmee verbonden zijn, te inventariseren zijn drie langetermijn-scenario's opgesteld voor de periode tot 2020" (CPB, 1997: 9). In de Milieuverkenning 5 van het RIVM (2000) wordt onzekerheid over de toekomst bijvoorbeeld expliciet genoemd als een reden om de milieuverkenning als een scenarioanalyse uit te voeren. De auteurs van de studie Beleef 2030 stellen dat "de toekomst is ongewis, maar het kan geen kwaad om erover na te denken" (Essent N.V., 2003) en de auteurs van het rapport Toekomstverkennen. De Radar op Scherp vermelden:

"Meer en meer groeit het inzicht dat de toekomst niet te voorspellen is door huidige ontwikkelingen door te trekken naar de toekomst, maar hooguit verkend kan worden. Maar ook het verkennen van de toekomst is het je wagen op glad ijs. Wat je niet weet (i.e. 
de toekom st), kan je namelijk niet onder woorden brengen" (BZK, 2005: 5)

Veel toekomstverkenners stellen dat, om recht te kunnen doen aan onzekerheid, wezenlijk verschillende perspectieven op de toekomst in beschouwing zouden moeten worden genomen. Al in 1988 stelde Eleonora Barbieri Masini, voormalig president van de 'World Futures Studies Federation', dat toekomstverkenning "should rather reveal the alternative possibilities, and analyze the risks concomitant of these possibilities and their consequences" (Barbieri Masini, 1988). De suggestie is dat, omdat de toekomst onbekend en ongekend is, verschillende, vaak conflicterende, toekomstbeelden legitiem zijn en daarom ook meegenomen zouden moeten worden in de toekomstverkenning. De ambitie is dan om de variëteit aan toekomstbeelden die denkbaar wordt door de toekomst vanuit verschillende perspectieven te beschouwen, te vertalen naar een set van scenario's (van der Heijden, 1996); (Schwartz, 1995); (Schwartz \& Ogilvy, 1998); (van Notten, 2005). Bradfield, Wright, Burt, Cairns, \& van der Heijden (2005) laten zien dat er veel verschillende definities van scenario's in omloop zijn ${ }^{7}$ en constateren dat "there are almost as many ways of developing scenarios as there are practitioners in the field" (800) (zie ook van Notten (2005)). Desondanks wordt algemeen onderschreven dat scenario's een hypothetisch karakter hebben. Ze zijn de resultante van een gedachteexperiment: "wat zou er kunnen gebeuren als..."? en beschrijven mogelijke paden naar de toekomst of een set van eindbeelden. Het gaat er dan niet meer om het beschrijven van een "waarschijnlijk" toekomstbeeld met eventueel een zogenaamde hoge en lage variant, maar om meerdere "scenario's" te ontwikkelen die wezenlijk andere richtingen uitwijzen doordat zij zich baseren op fundamenteel andere aannames over hoe het onder beschouwing zijnde systeem functioneert. In de scenarioliteratuur wordt het produceren van variatie genoemd als een centrale taak van toekomstverkenners. Bell (2000) stelt bijvoorbeeld in zijn boek Foundations of Futures Studies dat "one futurist task is to study possibilities for the future, no matter how unrecognized or improbable they may be" (Bell, 2000: 80). In dit boek definieert hij scenario's als verhalen "about alternative possibilities for the future, each having different probabilities of occurring under various conditions" (317). Schwartz, die door toekomstverkenners vaak wordt aangehaald als één van de pioniers in scenarioanalyse, beschrijft scenario's als "a tool for ordering one's perception about alternative future environments in which one's decision might be played out" (Schwartz, 1991: 4). Toekomstverkenners gebruiken scenario's dus om op gestructureerde wijze mogelijke toekomsten te verkennen. De suggestie is dat door verschillende scenario's te doordenken men beter in staat is in te spelen op

\footnotetext{
${ }^{7}$ De term 'scenario' is ontleend uit de theaterkunst en verwijst naar de beschrijving en opeenvolging van de scènes. Scenario's zijn gedachte-experimenten waarbij vanuit verschillende perspectieven op heden en verleden de toekomst wordt doordacht. Een scenarioproject is een specifiek soort toekomstverkenning, waarin een groep toekomstverkenners zich richt op het beschrijven van verschillende (meestal drie of vier) perspectieven op hoe de toekomst zich zou kunnen ontvouwen. In de volgende hoofdstukken zal ik hier dieper op ingaan.
} 
situaties en ontwikkelingen die zich in de toekomst zouden kunnen voordoen. Het gaat er in scenariostudies dus niet om de toekomst te voorspellen, maar om verschillende toekomsten (= scenario's) te beschrijven en op deze manier inzicht te krijgen in de mogelijke toekomsten. Scenario's worden in de praktijk dan ook vaak beschreven in termen van "variatie" en "differentiatie". De variatieambitie is dus als het ware de ambitie om heel verschillende toekomstbeelden (scenario's) te produceren met het doel beleidsmakers en andere gebruikers inzicht te geven in de aard van de onzekerheden waarmee de toekomst is omgeven.

Ook in de Nederlandse praktijk van beleidsgericht toekomstverkennen is de variatieambitie zichtbaar. Veel planbureaus and planbureau-achtige instituten produceren op reguliere basis scenariostudies. In de scenariostudie Nederland 2030 van de RPD worden scenario's bijvoorbeeld neergezet als "ruimtelijke visies, die wezenlijk verschillen in hun benadering" (RPD, 1997: 7). En de auteurs van derde Nationale Milieuverkenning van het RIVM beginnen hun studie met op te merken dat "uiteraard zijn de toekomstige maatschappelijke ontwikkelingen - zeker wanneer het gaat om een tijdsspanne van meer dan tien jaar - hoogst onzeker (RIVM, 1993: 33). Deze onzekerheid zetten zij in als legitimatie om verschillende "mogelijke - coherente en consistente - toekomstbeelden" te schetsen die "elk uitgaan van een andere visie". De auteurs van de Nationale Milieuverkenning 5 stellen dat "de processen in de beschrijvingen van verleden, heden en toekomst in deze milieuverkenning zijn doorspekt met onzekerheden" en dat om die reden gekozen is voor het maken van scenario's (RIVM, 2000: 36). De auteurs van de scenariostudie Lange-termijn bevolkingsscenario's voor Nederland zeggen de scenario-aanpak te beschouwen als "een middel om het hoofd te bieden aan de grote mate van onzekerheid over toekomstige ontwikkelingen" (CBS/RIVM, 2004: 13). En in de toekomstverkenning Scanning the Future van het CPB is te lezen dat "more consistent attempts are being made to cope with the enormous degree of uncertainty by means of sketching alternative worlds, each with its own opportunities, threats, surprises and strategies" (CPB, 1992: 34). Toekomstverkenners vertalen het besef van onzekerheid dus in de praktijk naar de ambitie variatie in toekomstbeelden te bewerkstelligen.

\section{De integratieambitie}

Een tweede ambitie die veel toekomstverkenners koesteren is het integreren van verschillende kenniselementen, disciplines en perspectieven. Centraal staat hier niet in de eerste plaats het garanderen dat de toekomstbeelden voldoende variëren (= de variatieambitie), maar dat zij voldoende variabelen afdekken. De vaak impliciete aanname daarbij is dat het integreren van verschillende wetenschappelijke disciplines en kenniselementen kan bijdragen aan een beter begrip van de complexiteit waarmee het verkennen van de toekomst is omgeven. Bell (2000) beargumenteert bijvoorbeeld dat "things cannot be held constant, separated into small bits for investigations out of 
their context and function" (90-91) en merkt "integrating knowledge and values" aan als één van de taken van toekomstverkenners. Veel beleidsgerichte toekomstverkenningen kenmerken zich door een holistisch perspectief. Integratie is een manier maar om nieuwe, slimme combinaties en inzichten op het spoor te komen die, vanuit een meer sectoraal of disciplinair perspectief, uit het zicht van de toekomstverkenner zouden blijven. De suggestie is dan dat het geheel meer is dan de som der delen en dat door te integreren meer en beter inzicht kan worden verkregen in nieuwe, nog niet gekende ontwikkelingen, mogelijke toekomstige knelpunten en innovatieve oplossingsrichtingen. Deze toekomstverkenners stellen dat, om beleid adequaat te kunnen ondersteunen en maatschappelijk relevant te kunnen zijn, een geïntegreerde aanpak noodzakelijk is en zoeken naar manieren waarop de verschillende wetenschappelijke disciplines en kenniselementen op een zinvolle manier met elkaar in verband kunnen worden gebracht.

De integratieambitie zit ook heel expliciet in de toekomstverkenningen die in de wereld van 'Integrated Assessment' zijn en worden ontwikkeld. 'Integrated Assessment' (IA) is een vakgebied dat zich bezig houdt met het integreren van maatschappelijke processen, vanuit het idee dat beleidsondersteuning het beste gebaad is bij het beschouwen van zo veel mogelijke relevante aspecten van een maatschappelijk probleem in hun onderlinge samenhang (zie bijvoorbeeld Rotmans (1998a; 1998b); van Asselt (2000) en van Asselt, Rotmans, \& Greeuw (2001)). Ook de scenario's van het IPCC kunnen onder het kopje 'Integrated Assessment' geschaard worden.

In de praktijk van toekomstverkennen komt de integratieambitie tot uitdrukking in uitspraken als: "De relaties tussen de voorraden en processen in de verschillende domeinen zijn complex, zowel binnen domeinen als ook tussen de domeinen" (RIVM, 2000: 33), en "de rol van de fysieke omgeving in het economische proces is veelomvattend en complex. Veelomvattend, vanwege de vele functies die de fysieke omgeving in het economische proces vervullen; en complex, vanwege het overlappende en interdependente karakter van de meeste van die functies" (CPB, 1997: 29). En om een beter inzicht en begrip te krijgen van deze complexiteit stellen de toekomstverkenners voor om verschillende "kernthema's" (CPB, 1992) "mechanismen" (RIVM, 2004), "future policy challenges" (CPB, 2003) of "indicatoren" (RIVM, 2004) in onderlinge samenhang te beschouwen.

De meeste toekomstverkenningen bevatten zowel elementen van de integratie- als de variatieambitie. Soms plaatsen toekomstverkenners de variatieambitie meer naar de voorgrond, soms de integratieambitie. In dit proefschrift beschrijf en analyseer ik hoe beide verkenningsambities tot uitdrukking komen in de praktijk van toekomstverkenning. Vragen die daarbij centraal staan zijn: Op welke manier manifesteren deze ambities zich in de praktijk en worden zij in de praktijk vormgegeven? En wat betekent dit voor de manier waarop toekomstkennis wordt geproduceerd en gecommuniceerd? 


\subsection{Toekomstverkenning als object van onderzoek}

Door de vraag op te werpen hoe toekomstkennis wordt geproduceerd plaats ik mij in een traditie van onderzoek naar toekomstverkenning. In de wereld der toekomstverkenning is een groot aantal handboeken met theoretische beschrijvingen van methoden en technieken van toekomstverkenning en hun toepassingen. Enkele bekende voorbeelden daarvan zijn Technological Forecasting in Perspective (Jantsch, 1967); Handbook of Futures Research (Fowles, 1978); Looking Forward: a guide to futures research (Helmer, 1983); The art of the long view (Schwartz, 1991); Scenarios: the art of strategic conversation (van der Heijden, 1996); Foundations of Futures Studies (Bell, 2000) en Principles of Forecasting (Armstrong, 2001). Het merendeel van deze literatuur over toekomstverkennen betreft voorstellen voor, of beschrijvingen van, specifieke methoden en technieken van toekomstverkenning. Deze literatuur gaat veelal uit van uniforme toepasbaarheid van voorgestelde methoden en technieken en geven daarmee weinig inzicht in de praktische aspecten van toekomstverkenning.

Naast deze theoretische handboeken is er de laatste jaren een aantal (wetenschaps) sociologische studies verschenen naar de (rol van de) toekomst in onze samenleving. Echter, in geen van deze studies zijn de "logics-in-use" (Ester, Geurts, \& Vermeulen, 1997) of "real time-activities" (Knorr-Cetina, 1981) van toekomstverkenners expliciet onderwerp van studie en informatiebron voor reflectie op methodologie. Van Lente (1993) kijkt in zijn proefschrift Promising Technology: The Dynamics of Expectations in Technological Development bijvoorbeeld naar de rol die verwachtingen en beloften spelen in technologische ontwikkelingen door verschillende niveaus waarop technologieontwikkeling plaats vindt aan de orde te laten komen (in het laboratorium, op het niveau van onderzoeksgebieden en interorganisationele verbanden en op het niveau van de samenleving als geheel). Het boek Contested Futures: A Sociology of Prospective Techno-science (Brown, Rappert, \& Webster, 2000) biedt verschillende sociologische perspectieven op hoe de toekomst door verschillende actoren in verschillende technologische praktijken wordt 'gekoloniseerd' en probeert een nieuwe basis te bieden voor "social responsibility for the future". Filosoof/kennissocioloog de Wilde (2000) bekritiseert in De Voorspellers: een Kritiek op de Toekomstindustrie wat hij noemt "de oppervlakkigheid en goedgelovigheid alsmede de fantasieloosheid waarmee in politieke en bestuurlijke kringen met de toekomst wordt omgegaan" (13). In elk van deze studies wordt de rol van toekomstkennis in onze huidige (technologische) samenleving geproblematiseerd en de lezer aangespoord kritisch om te gaan met verhalen en verwachtingen over de toekomst.

Naast deze sociologische studies naar de toekomst zijn er ook studies waarin expliciet wordt gekeken naar methodologie als proces van toekomstverkennen. Een zeer inspirerend voorbeeld waarbij expliciet gekeken werd naar methodologische aspecten van toekomstverkennen is het werk van van der Staal en van Vught (1987; 1988), die 
vijftien jaar toekomstonderzoek door de WRR analyseerden. Een andere studie is het proefschrift van de Man (1987) Energy Forecasting and the organisation of the policy process, waarin op het gebruik van (energie)prognoses in het beleidsproces in Nederland en het Verenigd Koninkrijk werd gereflecteerd. De auteurs Ester, Geurts, \& Vermeulen (1997) beschouwen in hun boek De makers van toekomst: Over nut en noodzaak van toekomstverkenningen voor beleidsonderzoek toekomstverkennen vanuit zowel het perspectief van de wetenschap, het beleid als de praktijk. En een ander voorbeeld is het proefschrift van de socioloog/bestuurskundige Dammers (2000) Leren van de toekomst, waarin hij onderzocht welke rollen scenario's vervullen in het beter hanteerbaar maken van onzekerheden. In deze studies staat het gebruik van toekomstkennis in beleid centraal. In het proefschrift Scripts for the Future ontwerpt de Laat (2000) een verkenningsmethode die kan ondersteunen bij het proces van strategische beleidskeuze en waarin de nadruk ligt op het expliciteren van de toekomstige socio-technische netwerken die actoren construeren. Dit proefschrift heeft, in tegenstelling tot bovengenoemde studies een sterk (methodologisch) ontwerpelement.

Wat al deze studies gemeenschappelijk hebben, is dat in retrospectief wordt gekeken naar praktijken van toekomstverkenning. Voor het kunnen beantwoorden van de vraag hoe toekomstkennis wordt geproduceerd lijkt een retrospectief onderzoek naar methodologie van toekomstverkenning ons niet veel verder te helpen. Het proces van toekomstverkennen is namelijk slecht uit de officiële rapporten en publicaties af te leiden (Dobbinga, 2001; van Asselt, 2003). Als er al het een en ander over het onderliggende proces expliciet is vastgelegd in de toekomstverkenning zelf, dan is dat meestal een zeer korte en bondige verantwoording van de zogenaamde belangrijkste stappen en keuzes, dat een lineair verloop suggereert. Van der Staal en van Vught constateerden in 1988 in hun evaluatie van de toekomstverkennende activiteiten van de WRR dat "zoals (..) gebruikelijk ziet dit beeld (over de totstandkoming, sk) er enigszins anders uit dan in de eindrapportage is geconstrueerd" (van der Staal \& van Vught, 1988). Deze observatie wordt, bijna twintig jaar later, in meer algemene zin onderschreven door redacteuren bij de Gezondheidsraad: "Je krijgt als lezer niet altijd veel inzicht in het proces", waarbij dan verwezen wordt naar aspecten als afwegingen, de geschiedenis van totstandkoming, wat makkelijk en moeilijk ging en waar misschien tegenstrijdigheden zaten (Bal, Bijker, \& Hendriks, 2002). Deze aspecten worden dus meestal geen onderdeel van het officiële historische narratief. De geschiedenis van de totstandkoming van een toekomstverkenning en de moeilijkheden die daarmee gepaard gaan, onttrekken zich dus veelal aan het oog van de lezer van de rapporten geproduceerd door toekomstverkenners zelf. Deze lezer krijgt een gestileerd verhaal waarin, als er al het een en ander over het onderlinge proces expliciet is vastgelegd, alleen een aantal stappen en keuzes worden verantwoord. In toekomstverkenningen wordt het proces van totstandkoming in de regel zeer summier geëvalueerd.

Een manier om inzicht te krijgen in de manier waarop toekomstverkenners de toekomst 
verkennen, is om zelf getuige te zijn van het toekomstverkenningproces en de productie van toekomstkennis van binnenuit te beschrijven. Naar deze onderzoeksstijl wordt ook wel verwezen met de term 'etnografie'. Met deze etnografische onderzoeksaanpak plaats ik mij in een traditie van onderzoek naar kennisproductie. Het observeren, bestuderen en beschrijven van de dagelijkse praktijk van toekomstverkenners was voor mij een manier om te leren hoe toekomstverkenners toekomstkennis produceren (zie ook hoofdstuk 2 voor een gedetailleerde beschrijving van mijn onderzoeksaanpak).

Naar de productie van toekomstkennis heeft nog nauwelijks onderzoek plaatsgevonden. Een studie waarin het proces van toekomstverkennen 'in actie' wordt beschreven is het proefschrift van de organisatie-antropologe Dobbinga (2001). Zij reflecteert op de productie en het gebruik van scenario's door het ministerie van Verkeer en Waterstaat als managementinstrument om het traditionele denken en handelen te 'ontstroeven'. Zij laat methodologie van toekomstverkennen echter links liggen en constateert daarover alleen dat "de scenario methode is gebruikt". Zij beschrijft niet het proces van toekomstkennisproductie, maar problematiseert de weerbarstigheid van organisaties voor toekomstverkenning. Het proefschrift van de communicatiewetenschapper Brooks (2004) Working in the Future Tense is een studie naar de praktijk van toekomstverkennen bij het Amerikaanse 'Institute for the Future' (IFTF, een in 1968 opgerichte non-profit organisatie in Amerika die bedrijven, federale diensten en non-profit organisaties adviseert over het maken van lange termijn strategieën voor innovatie). Dit proefschrift biedt vooral een beschrijving en nauwelijks analyse van hoe deze toekomstverkenners de toekomst verkennen. En in Oxford doet Ju Min Wong momenteel, onder leiding van Steve Woolgar, onderzoek naar het gebruik van experts en expertise in toekomstverkenningen.

Het analyseren van de manieren waarop toekomstkennis wordt geproduceerd is belangrijk omdat het bijdraagt aan een beter begrip van wat zich achter de schermen afspeelt. Wetenschapssociologen hebben overtuigend laten zien dat de productie van kennis alles behalve lineair verloopt en dat wetenschappers wetenschappelijke 'feiten' niet 'ontdekken', maar 'construeren' (zie ook voetnoot 3). Inzicht in het proces zou kunnen helpen om toekomstverkenners en buitenstaanders inzicht te verschaffen in hoe de toekomst wordt verkend en verkend kan worden, wat ook kan helpen de resultaten van toekomstverkenningexercities beter op hun merites te beoordelen en te gebruiken in beleidsprocessen. Dergelijke reflectie op het proces van toekomstverkenning wordt door verschillende auteurs bepleit (o.a. van der Staal \& van Vught (1987; 1988); Ester, Geurts, \& Vermeulen (1997); Dammers (2000); WRR (2000) en Bell (2000)). Ook empirisch geïnformeerde reflecties lijken zeldzaam. Zo stelt Bell (2000) bijvoorbeeld dat "with a few exceptions (..) the major issues of the nature of knowledge in the futures field (..) have received relatively little sustained attention and critical thought"(87). Met dit proefschrift kan ik deze lacune niet dichten. Wel kan ik een serieuze poging doen om systematisch te beschrijven en te analyseren op welke manier toekomstverkenners kennis over de toekomst produceren. 


\subsection{De toekomstverkennende praktijk bij het Ruimtelijk Planbureau}

Nederland en Nederlanders zijn verhoudingsgewijs actief op het terrein van toekomstverkennen. Zo stonden bijvoorbeeld de Milieuverkenningen van het RIVM ${ }^{8}$ (RIVM, 1993; 1997)) model voor de Global Environmental Outlook (UNEP, 1997) van de Verenigde Naties en de milieuverkenningen van het Europees milieuagentschap (EEA, 1995). Het RIVM wordt in dergelijk internationale milieuverkenningen ook vaak een actieve en verantwoordelijke rol toebedeeld. Scanning the Future (CPB, 1992) van het CPB wordt niet alleen in Nederland, maar ook daarbuiten veelvuldig geciteerd. Leidende figuren in de ontwikkeling van scenariomethodologie bij Shell (zoals de Geus en van der Heijden) waren Nederlanders. Deze indicatoren geven aan dat onderzoek naar de Nederlandse praktijk van beleidsgerichte toekomstverkenning inzichten kan opleveren die ook interessant zijn in breder internationaal perspectief.

De Nederlandse planbureaus worden door de Nederlandse beleidswereld gezien als een van de, of misschien wel de, belangrijkste producenten van toekomstkennis. Daarmee belichamen zij als het ware de institutionalisering van toekomstverkenning in de Nederlandse beleidsarena. Om inzicht te krijgen in de Nederlandse praktijk van toekomstverkennen lijkt het dus logisch om een planbureau te kiezen als onderzoekscasus voor etnografisch onderzoek .

Nederlandse planbureaus produceren hun verkenningen van de toekomst deels op eigen initiatief en deels in opdracht of op verzoek van overheden. Zij nemen in de Nederlandse beleidsarena een bijzondere positie in, omdat zij zich bewegen op het snijvlak tussen wetenschap, beleid en maatschappij. Specifiek aan de planbureaucontext is de zogenaamde "dienstbare opstelling" van experts (zie RPB (2006)), hetgeen slaat op de ambitie om kennis te produceren die beleidsrelevant is. De term beleidsrelevant wil zeggen dat het onderzoek bijdraagt aan redelijke besluitvorming, bijvoorbeeld door nieuwe politieke vragen op te werpen en onderbouwde suggesties voor handelingsmogelijkheden te bieden. De planbureaus hebben de wettelijke taak informatie en inzichten te produceren die "relevant zijn voor het strategisch beleid van het kabinet" (Protocol voor de planbureaufunctie van CPB, RIVM, RPD en SCP, 1998). Anders dan adviesraden hebben de planbureaus een directe, formele link met bewindslieden. Zo hebben de planbureaudirecteuren op uitnodiging toegang tot de ministerraad en zijn zij lid van de onderministerraden. Planbureaus zijn dus direct betrokken bij de voorbereiding van het nationale beleid. Andersom kan de ministerraad onderwerpen aanwijzen waaraan

\footnotetext{
${ }^{8}$ Sinds 1 januari 2006 is dit het Milieu- en Natuurplanbureau (MNP); een tak van het RIVM die verantwoordelijk is voor het maken van beleidsgerichte toekomstverkenning.

${ }^{9}$ Toekomstverkenning is slechts een van de activiteiten van de planbureaus, maar wel een van de zeer zichtbare.
} 
een planbureau aandacht zou moeten besteden in haar werkprogramma ${ }^{10}$. Planbureaus bedienen bovendien niet alleen de regering en parlement, maar ook decentrale overheden. Tegelijkertijd staat onafhankelijkheid ten opzichte van de ministeries staat bij de planbureaus hoog in het vaandel. De planbureaus willen voorkomen door de buitenwereld te worden gezien als een verkapt verlengstuk van de ministeries of als loopjongen van de politiek. Zo stelde de directeur van het RPB: "We bepalen zelf welke rapporten we uit willen brengen. We zullen de politiek natuurlijk niet overvallen, maar wij beslissen wanneer we naar buiten komen. De minister kan dus niet zeggen: "Het komt me nu niet zo goed uit"” (Derksen, 2002).

Van planbureaus wordt niet alleen verwacht dat zij beleidsrelevante informatie en inzichten bieden, maar ook dat die informatie en inzichten wetenschappelijk gefundeerd zijn. Planbureaus positioneren zich dan ook als onafhankelijke, wetenschappelijke instituten en benadrukken het belang van wetenschappelijke verankering en het presenteren van "betrouwbare, niet-gekleurde gegevens" (RPB, 2004). Don, de toenmalige directeur van het CPB, schreef bijvoorbeeld: "We willen voldoen aan wetenschappelijke normen omdat die de kern vormen van de kwaliteit van ons werk" (Don, 2003: 20). En de directeur van het RIVM stelde expliciet in een krantenartikel dat de ambitie is dat de uitgebrachte toekomstverkenningen de wetenschappelijke toets der kritiek kunnen doorstaan (van Egmond, 1999). De planbureaus positioneren zich primair als een kennisinstituut en geven aan dat zij samenwerking met universiteiten in binnenen buitenland, internationale vergelijkingen en publicaties in de wetenschappelijke literatuur koesteren.

Het Ruimtelijk Planbureau lijkt om een aantal redenen een interessante casus om te begrijpen hoe toekomstverkenners de toekomst verkennen ${ }^{11}$. Het RPB werd opgericht op 1 januari 2002 en neergezet als het onderzoeksinstituut voor de ruimtelijke ordening in Nederland (zie box 1 voor een korte oprichtingsgeschiedenis van het RPB). Dit planbureau is daarmee het jongste planbureau in Nederland ${ }^{12}$. Hoewel het RPB het jongste planbureaus is in Nederland bouwt dit planbureau tegelijkertijd voort op een relatief lange scenariotraditie. De Rijksplanologische Dienst heeft een aantal toonaangevende scenariostudies gepubliceerd, waaronder de studie Scenario's ten behoeve van de Verstedelijkingsnota (1975), één van de eerste scenariostudies in Nederland, en Nederland 2030 (1997). De variatieambitie lijkt, met andere woorden, dus al voor de oprichting van het RPB startpunt te zijn van toekomstverkennende activiteiten

\footnotetext{
${ }^{10}$ Het Ruimtelijk Planbureau is momenteel bezig met de uitwerking van het vierde werkprogramma.

${ }^{11}$ De Milieuverkenningen van het RIVM waren reeds in het proefschrift van van Asselt (2000) object van onderzoek en de activiteiten van het SCP en het CPB worden in het onderzoeksprogramma 'Rethinking' onderzocht (Hoppe, 2005) (zie ook www.bbt.utwente.nl/rethinking/)

${ }^{12}$ Sinds 1 januari 2006 is het Milieu- Natuurplanbureau opgericht. Dit is echter een onderdeel van het RIVM en daarmee geen nieuw onafhankelijk planbureau.
} 
op het gebied van de ruimtelijke ordening. In het oprichtingsbesluit van het RPB werden de toekomstverkenningsactiviteiten vastgelegd en werd vastgesteld dat "Ruimtelijke Verkenningen één van de centrale producten" is van het Ruimtelijk Planbureau (TK, 20002001, 27 679, nr. 1). Het planbureau heeft de taak elke twee jaar te inventariseren wat de toekomstige ruimtebehoeftes zijn en "varianten van ruimtelijk beleid en scenario's" te ontwikkelen (RPB, 2001).

\begin{abstract}
Box 1. Een korte oprichtingsgeschiedenis van het Ruimtelijk Planbureau
Al tijdens de Tweede Wereldoorlog, in 1941, werd door de Duitse bezetters de Rijksdienst voor het Nationale Plan (RNP) opgericht die belast werd met de "ruimtelijke ordening der nationale belangen, het toezicht op de ruimtelijke ordening der streekbelangen en gemeentelijke belangen en het onderzoek, dat als basis voor deze ordening zal dienen" (art. 1.1 Basisbes/uit). Vanaf de oprichting had deze voorloper van het RPB een dubbele identiteit. Als onderzoeksdienst moest de RNP ontwikkelingen in de ruimtelijke ordening op afstand analyseren en bestuderen en advies geven over de ruimtelijke ordening. Als beleidsdienst toezicht houden op de naleving van wet en de minister van ruimtelijke ordening assisteren (de Ruijter, 1975). In het jaar 1946 onderging de Rijksdienst een naamsverandering en ging het de Rijksplanologische Dienst (RPD) heten.

Net als de RNP worstelde de RPD met zijn dubbele identiteit. Bewust van deze kwetsbare positie waarbij de RPD beleidsadviezen maakte en zichzelf daarbij kritisch moest volgen, adviseerde een parlementaire werkgroep de Rijksplanologische Dienst in 2000 als het ware in tweeën te delen. De eerste stap was de oprichting van de Directoraat-generaal Ruimte onder VROM dat uitsluitend als beleidsdienst opereert. De tweede stap was de oprichting van een nieuw en onafhankelijk Ruimtelijk Planbureau - het RPB - dat een belangrijke taak kreeg in het "het verkennen en signaleren van ruimtelijk relevante maatschappelijke ontwikkelingen" (RPB, 2004).
\end{abstract}

Toekomstverkenners bij het RPB nemen expliciet afstand van de traditionele, sectorale manier van denken. Zij stellen bijvoorbeeld:

"Bij ruimtelijke ordening gaat het om een integrale benadering. Je kunt geen thema's weglaten. We moeten integraal zijn. Op de onderzoekslijnen moeten we blijven kiezen voor integraliteit" (Bijeenkomst RPB, 7 april 2003).

De suggestie is dat ruimtelijke vraagstukken niet kunnen worden begrepen door alleen naar ontwikkelingen op het gebied van wonen te kijken, want waar mensen wonen heeft invloed op waar mensen werken en recreëren. En waar mensen willen werken heeft invloed op waar zij wonen. En dat bepaalt weer de mobiliteit, wat weer invloed heeft op natuur en milieu, gezondheid en veiligheid, etc. Het RPB heeft dus zowel variatie als 
integraliteit hoog in het vaandel staan ${ }^{13}$. De Rijksplanologische Dienst, de voorganger van het RPB, wordt door toekomstverkenners van het RPB vaak neergezet als een organisatie die de oude generatie representeert. Zo stelt één van de toekomstverkenners: "In de Rijksplanologische dienst was het verkennen wel multi-sectoraal, maar nog in de oude filosofie en waarin men ervan uitging dat je de opgave kan bepalen" (Bijeenkomst RPB, 25 augustus 2003: 8).

In de periode $2002-2006$ is het RPB uitgegroeid tot een organisatie met ongeveer 60 vaste medewerkers, waarvan het merendeel een academische achtergrond heeft. De belangrijkste disciplines die binnen het RPB worden vertegenwoordigd zijn economie, econometrie, bestuurskunde, politicologie, sociologie, stedenbouwkunde, landschapsarchitectuur, planologie en sociale geografie. De toekomstverkenners bij het RPB zien zichzelf niet primair als toekomstverkenners, maar als inhoudsdeskundigen die zich (ook) met de toekomst bezighouden en die vanuit hun inhoudelijke expertise toekomstige ontwikkelingen in hun vakgebied kunnen schetsen (vergl. van der Duin, Hazeu, Rademaker, \& Schooneboom (2006)).

\section{$1.5 \quad$ Drie gevalsstudies}

Ik heb in de periode van december 2001 tot en met december 2004 (met uitloop in 2005 en 2006) drie toekomstverkennende projecten van het Ruimtelijk Planbureau intensief geobserveerd; te weten SCENE, WR en WLO. Voor elk van deze studies geldt dat zij door de betrokken planbureaus zijn geïnitieerd en gefinancierd. Dit betekent dat er geen sprake is van een 'klassieke' opdrachtgever - opdrachtnemer relatie (zoals dat bijvoorbeeld wordt beschreven in het WRR-rapport Terugblik op Toekomstverkenningen (WRR, 2000). Onderstaande inleidende beschrijvingen zijn gebaseerd op hoe de toekomstverkenners zelf het project beschrijven (of zouden kunnen beschrijven).

SCENE is de afkorting van "een kwartet ruimtelijke SCEnario's voor NEderland" en had een looptijd van september 2001 tot en met mei 2002. Het rapport verscheen in mei 2003. SCENE was een scenarioproject en had het doel te "verkennen wat het langetermijnverloop is van de maatschappelijke ontwikkelingen die ruimtelijk relevant zijn" (RPB, 2003b). Het SCENE-project wordt door de betrokken toekomstverkenners gekarakteriseerd als een kwalitatieve scenariostudie. Richtinggevend bij de ontwikkeling van scenario's waren de resultaten van drie Delphi-ronden ${ }^{14}$ en twee

\footnotetext{
${ }^{13}$ Tegelijkertijd stelt het RPB ook dat niet elke studie de wereld in samenhang hoeft te zien: "We willen ook dienstbaar zijn door kleinere boeken en adviezen in kortere tijd af te leveren. We moeten onze kracht dus ook zoeken in het beantwoorden van kleinere, veelal sectorale vragen" (RPB, 2006)

${ }^{14}$ De Delphi-methode is ontwikkeld door RAND Corporation in de jaren vijftig van de vorige eeuw
} 
werkconferenties. Hiervoor had het projectteam "een brede groep van creatieve en deskundige medewerkers van overheden, maatschappelijke organisaties, bedrijven en kennisinstellingen die bij het ruimtelijke beleid zijn betrokken" (RPB, 2003b) uitgenodigd, die werden uitgedaagd om na te denken over hoe de toekomst er uit zou kunnen zien. De resultaten hiervan (drijvende krachten, ingetekende kaarten, trefwoorden, causale diagrammen, tekeningen) werden vervolgens door het projectteam gebruikt als startpunt en inspiratie voor het ontwikkelen van vier toekomstscenario's. Het zogenaamde kernteam bestond uit twee projectleiders, een projectsecretaris en vier onderzoekers die elk weer deelprojectleider waren van vier deelprojecten die elk een ander schaalniveau belichtten 'Internationaal: Nederland als regio in Europa', Nationaal: Stedelijke Netwerken', 'Regionaal en lokaal: Stad \& Land' en 'Ondergrond: Water'. In totaal waren bij de SCENE toekomstverkenning 7 kernteamleden en ongeveer 20 andere toekomstverkenners betrokken van zowel het Ruimtelijk Planbureau als andere planbureaus (het MNP) en planbureau-achtigen (het RPD, Het Rijksinstituut voor Kust en Zee (RIKZ), het Rijksinstituut voor Zoetwaterbeheer en Afvalwaterbehandeling (RIZA), Accanto, Alterra, het Landbouw Economisch Instituut (LEI), Royal Haskoning en TNOInro).

In het rapport worden vier scenario's gepresenteerd (zie box 2 voor een beknopte samenvatting), die, aldus de auteurs van het SCENE-rapport "hoofdzakelijk kwalitatieve uitspraken (bevatten, sk), die slechts globaal zijn onderbouwd" (RPB, 2003b: 7). Kwantitatieve datasets en het gebruik van rekenmodellen spelen in deze studie een zeer ondergeschikte rol. De scenario's behandelen elk een aantal maatschappelijke ontwikkelingen op verschillende schaalniveaus.

en kan worden opgevat als een min of meer geformaliseerde brainstorm. Het is een combinatie van individuele en collectieve brainstorm. De eerste ronde is in het algemeen blanco. In de daarop volgende rondes wordt enerzijds wel gepoogd de ideeën uit de vorige ronde aan te vullen en te verrijken, terwijl tegelijkertijd het doel is om geleidelijk tot convergentie te komen. In de meeste gevallen wordt de Delphi-methode ingezet voor een bevraging van experts. In een eerste ronde kunnen experts gevraagd worden welke toekomstige ontwikkelingen zij voorzien/kunnen bedenken. De experts krijgen dan het gezamenlijke resultaat van de eerste ronde als inbreng voor de tweede ronde. In een tweede ronde zouden ze gevraagd kunnen worden of er nog ontwikkelingen missen, en welke ontwikkelingen het belangrijkste worden gevonden. In een derde ronde worden ze vervolgens met elkaars prioriteiten geconfronteerd en wordt hen gevraagd nogmaals te prioriteren. In een volgende ronde zou hen dan ook nog gevraagd kunnen worden de ontwikkelingen in te schatten. Vervolgens worden ze dan weer met elkaars inschattingen geconfronteerd, op basis waarvan ze gevraagd worden een nieuwe inschatting te geven. Dit gaat door totdat degene die de Delphi organiseert vindt dat voldoende convergentie is bereikt. Een Delphi-ronde wordt meestal schriftelijk/elektronisch gedaan, om discussie tussen experts te voorkomen, en voldoende tijd te hebben om de individuele input te verwerken tot een collectief overzicht (Linstone \& Turoff, 1975) (Hill \& Fowles, 1975) (Rowe \& Wright, 1999, 2001). 
Box 2. De vier SCENE scenario's in het kort (gebaseerd op RPB (2003b))

- 'Nederland als overlevingsruimte' wordt gekenmerkt door stagnatie en conflict. Het is het scenario met een lage economische groei, weinig innovatie, gebrekkige politieke bes/uitvorming en grote maatschappelijke conflicten.

- Het scenario 'Nederland als belevingsruimte' staat daarentegen in het teken van duurzame ontwikkeling. Hoewel mensen een groot belang hechten aan het behouden of versterken van de kwaliteit van de leefomgeving neemt de ruimtedruk toe. Dit als gevolg van de economische groei.

- In het scenario 'Nederland als productieruimte' breekt de kennis- en innovatieeconomie door. Niet iedereen kan echter profiteren van de hoge economische groei en er ontstaat een sterke maatschappelijke segregatie tussen de "haves" en de "havenots". Ook komt de kwaliteit van de leefomgeving onder druk te staan.

- 'Nederland als milieuruimte' is het scenario van de 'verantwoorde economie'. Milieu en samenleving stellen grenzen aan de groei en er wordt veel geïnvesteerd in schone en veilige technologie. Inkomensverschillen nemen af, tolerantie neemt toe en er treden nauwelijks conflicten op.

De tweede toekomstverkenning 'Verkenning van de Ruimte' (VVR) liep van juni 2002 tot november 2003. Het rapport De ongekende ruimte verkend verscheen in december 2003. Aan deze toekomstverkenning hebben zo'n dertig verschillende mensen van het RPB in verschillende fasen, verschillende intensiteiten en verschillende samenstellingen meegewerkt. Het uiteindelijke rapport is geschreven en afgerond door zeven onderzoekers van het RPB.

Met dit project beoogden de toekomstverkenners inzicht te geven in de vraag "Wat is de ruimtebehoefte in Nederland voor de komende decennia?" (RPB, 2003a). Het WR-project werd door de betrokken toekomstverkenners niet gepresenteerd als een scenarioproject, maar als een "prognosestudie". De prognoses die in WR werden ontwikkeld zijn kwantitatieve doorvertalingen van maatschappelijke ontwikkelingen op vier beleidsterreinen, namelijk Wonen, Werken, Landbouw en Water (zie box 3 voor een voorbeeldprognose uit WR). Om de onzekerheidsmarge van het toekomstbeeld aan te geven werd toekomst niet weergegeven als een puntschatting, maar gaven de verkenners een bandbreedte aan waarbinnen trends zich waarschijnlijkerwijs zouden ontwikkelen.

Kenmerkend voor dit project was de ambitie mensen van twee verschillende culturen van toekomstverkenning met elkaar te laten samenwerken, namelijk onderzoekers en ontwerpers. De verwachting was dat door zowel onderzoekers als ontwerpers bij de toekomstverkenning te betrekken gekomen kon worden tot nieuwe, innovatieve inzichten en oplossingsrichtingen. 
Box 3. Een voorbeeldprognose uit VVR

Een prognose voor het thema 'Wonen' die in het rapport De ongekende ruimte verkend wordt gemaakt is bijvoorbeeld:

"In 1950 maakte Europa 21 procent uit van de wereldbevolking; dat is 57 miljoen inwoners. In 2000 was dit nog maar 11 procent (728 miljoen) en naar verwachting zal het aandeel van de Europese bevolking in de wereldbevolking in het jaar 2050 nog maar 7 procent bedragen (632 miljoen)" (RPB, 2003a: 28).

In het eindrapport is de oorspronkelijke doelstelling, namelijk het in kaart brengen van de ruimtebehoefte in Nederland, verlaten en pleiten de toekomstverkenners voor een nieuw perspectief op de ruimtelijke ordening. In deze nieuwe insteek krijgen de gemaakte prognoses een andere betekenis, namelijk als "tamelijk willekeurig gekozen" beleidsterreinen waarop dit perspectief wordt verkend (RPB, 2003a).

De laatste toekomstverkenning 'Welvaart en Leefomgeving' (WLO) ging begin 2004 van start en liep tot juli 2006. Het rapport verscheen eind september 2006. WLO was een gezamenlijk project van drie planbureaus, namelijk het RPB, het CPB en het MNP. Het was voor het eerst dat de drie planbureaus op gelijkwaardige basis trachtten samen te werken aan één scenariostudie. Daarnaast hebben ook andere instituten een bijdrage geleverd aan deze studie, zoals het Sociaal en Cultureel Planbureau (SCP) het Energieonderzoek Centrum Nederland (ECN), het Landbouw Economisch Instituut (LEI), Adviesbureau ABF, Senter-Novem, het CBS en de Algemene Verkeer- en Vervoerdienst (AWV). Aan de studie hebben zo'n 40 mensen gewerkt, waarvan 12 zitting hadden in het zogenaamde 'Trekkersoverleg', het vergaderplatform waarin de projectleiders van de verschillende themagroepen regelmatig samenkwamen om hun deelresultaten op elkaar af te stemmen.

Het doel van de studie was het "verkennen van mogelijke en waarschijnlijke toekomstige knelpunten in onze fysieke omgeving" (WLO Discussiedocument, 2003). WLO was, net als SCENE, een scenarioproject. Het WLO-project had tot doel scenario's te ontwikkelen voor het jaar 2040 die samen "een geloofwaardig beeld (geven, sk) van de mogelijke ontwikkelingen in de Nederlandse leefomgeving". De studie beoogde een beeld te geven van de veranderingen die kunnen optreden op een groot aantal terreinen (waaronder de bevolkingssamenstelling, de economie, het consumptiepatroon, het energie- en brandstofgebruik, de landbouwproductie) en de gevolgen daarvan voor de fysieke omgeving (ruimte, milieu, natuur, mobiliteit, etc.). Voor een aantal onderwerpen werden zogenaamde "knelpunten" geïdentificeerd en geïnventariseerd welke dilemma's zich daarbij voor kunnen doen. Met deze studie beoogden de toekomstverkenners "het 
maatschappelijke debat te ondersteunen dat nodig is bij de beleidsmatige keuzes" die voor de lange termijn gemaakt moeten worden (WLO Concept samenvatting, 2006). De verwachting was dat de scenario's die deze studie zou opleveren, zouden worden gebruikt in diverse beleidsnota's en departementale onderzoeken (WLO Plan van Aanpak, 2003: 2).

In de WLO toekomstverkenning werden vier scenario's ontwikkeld met de namen 'Regional Communities', 'Strong Europe', 'Transatlantic Market' en 'Global Economy', die, aldus de toekomstverkenners "elk uit een realistische combinatie van mogelijke ontwikkelingen bestaan" (WLO Concept samenvatting, 2006) (zie box 4). In WLO werd een groot arsenaal aan rekenmodellen ingezet om zowel waarschijnlijke als mogelijke ontwikkelingen op het gebied van wonen, werken, mobiliteit, grootstedelijke ontwikkelingen, energie, veiligheid, landbouw, milieu en natuur en water te kunnen doorrekenen.

In elk van de drie toekomstverkenningen zijn zowel verwijzingen naar de variatieals de integratieambitie terug te vinden. De manier waarop toekomstverkenners hun toekomstverkenning positioneerden was echter steeds verschillend: In SCENE plaatsten de toekomstverkenners vooral de variatieambitie op de voorgrond. In VVR was juist de integratieambitie het startpunt van de toekomstverkenning en verwezen de toekomstverkenners naar de variatieambitie als iets wat zij niet ambieerden. De toekomstverkenners in WLO, daarentegen, stelden zichzelf tot doel zowel te integreren als te variëren: het ging in deze toekomstverkenning zowel om het ontwikkelen van een gevarieerde set van toekomstbeelden als het integreren van verschillende kenniselementen, disciplines en perspectieven.

Ik wil niet pretenderen dat deze drie toekomstverkenningen representatief zijn voor de manieren waarop de toekomst bij andere instituten en door andere toekomstverkenners wordt verkend. Wel pretendeer ik fundamentele patronen en mechanismen bloot te kunnen leggen op basis van deze drie projecten en mijn kennis en ervaring met andere toekomstverkennende praktijken. Van deze patronen en mechanismen, die ten grondslag lijken te liggen aan toekomstverkenning, is het aannemelijk dat zij ook in andere praktijken dan het RPB terug te vinden zijn. Mogelijkerwijs in andere gedaanten, in een andere volgorde of met een andere uitwerking. Mijn ambitie is om analytisch generaliseerbare inzichten te bieden over toekomstverkenning als praktijk.

Dit proefschrift beschrijft hoe toekomstverkenners kennis over de toekomst produceren. Ik constateerde dat hedendaagse toekomstverkenners zich veelal positioneren binnen een nieuwe toekomstoriëntatie, waarbij onzekerheid en complexiteit centrale noties zijn en liet zien dat toekomstverkenners het besef van onzekerheid en complexiteit in de praktijk van toekomstverkennen vertalen naar de variatieambitie (onzekerheid) en de integratieambitie (complexiteit). 
Box 4. De vier scenario's in het kort (gebaseerd op het document 'Concept Samenvatting van de WLO-studie', versie 17 januari 2006)

- In het scenario 'Regional Communities' slaagt de Europese Unie er niet in om institutionele hervormingen door te voeren. De internationale handelsliberalisatie komt niet van de grond, waardoor de wereld uiteenvalt in een aantal handelsblokken. De economische groei in Nederland is gering, de arbeidsparticipatie relatief laag en de werkloosheid hoog. Het sociaal-economische beleid is gericht op solidariteit en gelijkmatige inkomensverdeling. Vanwege de lage economische groei is ook de milieudruk in dit scenario relatief laag.

- In 'Strong Europe' is er juist veel aandacht voor internationale samenwerking. De Europese instituties worden succesvol hervormd en Europa wordt een invloedrijke speler op het economische en politieke toneel. Het sociaal-economische beleid is gericht op solidariteit en gelijkmatige inkomensverdeling. Door een aantal sociaaleconomische hervormingen, hoge investeringen in onderwijs en onderzoek en de grotere markt komt is de arbeidsproductiviteit groter en de economische groei hoger dan in 'Regional Communities'.

- Terwijl in 'Transatlantic Markets' de uitbreiding van de Europese Unie geen politiek succes is, vindt er een vergaande handelsliberalisatie plaats tussen de Verenigde Staten en Europa, waardoor een nieuwe interne markt ontstaat. Doordat de verzorgingsstaat wordt ingeperkt en publieke voorzieningen worden versoberd neemt de inkomensongelijkheid toe. De groei van de arbeidsparticipatie en de economische groei zijn groot en de internationale concurrentie verhoogt de prikkel om te innoveren. Milieuvraagstukken worden niet grensoverschrijdend, maar lokaal aangepakt.

- In het scenario 'Global Economy' breidt de Europese Unie zich uit naar het oosten. De WTO onderhandelingen zijn succesvol en de internationale handel vaart er wel bij. Politieke integratie komt echter niet van de grond. De groei van de arbeidsproductiviteit en de economie krijgen een sterke impuls door de wereldwijde economische integratie. De wereldwijde economische groei en het falen van de aanpak van grensoverschrijdende milieuproblemen leiden tot forse milieuvervuiling. Wel leidt de hogere welvaart tot lokale milieu-initiatieven.

Ik baseer mijn beschrijving van deze centrale ambities, en hoe die worden uitgewerkt in de praktijk, op meerjarig etnografisch onderzoek bij drie toekomstverkenningsprojecten bij het Ruimtelijk Planbureau. Door het beschrijven van de dagelijkse praktijk en het zichtbaar maken van mechanismen en patronen in de productie van toekomstkennis probeer ik een bijdrage te leveren aan de discussie over de productie van (toekomst)kennis en over methodologie van toekomstverkenning.

Tijdreizen is niet mogelijk: we kunnen dus geen verkenners op pad sturen om de toekomst te verkennen. Het enige dat we kunnen, is het doen van gedachte- 


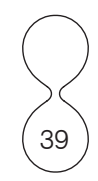

experimenten en analytische oefeningen waarin we reflecteren en speculeren op hoe de toekomst eruit zou kunnen zien. In dit proefschrift zal ik proberen een indruk te geven van problemen en uitdagingen die bij het verkennen van de toekomst op de loer liggen. 
"Our world is full of ships already within their bottles and it is only the rare individual who gets a brief glimpse of the ships-in-6ottle maker's art" (Collins, 1985). 
$\left(\frac{13}{4}\right)$
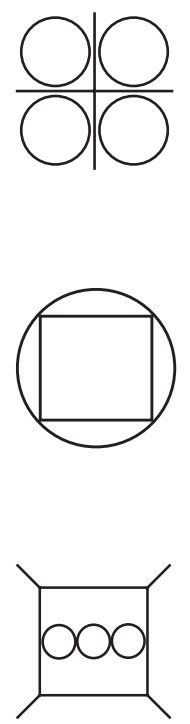

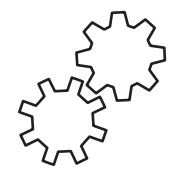




\section{(2) Een nadere kennismaking}

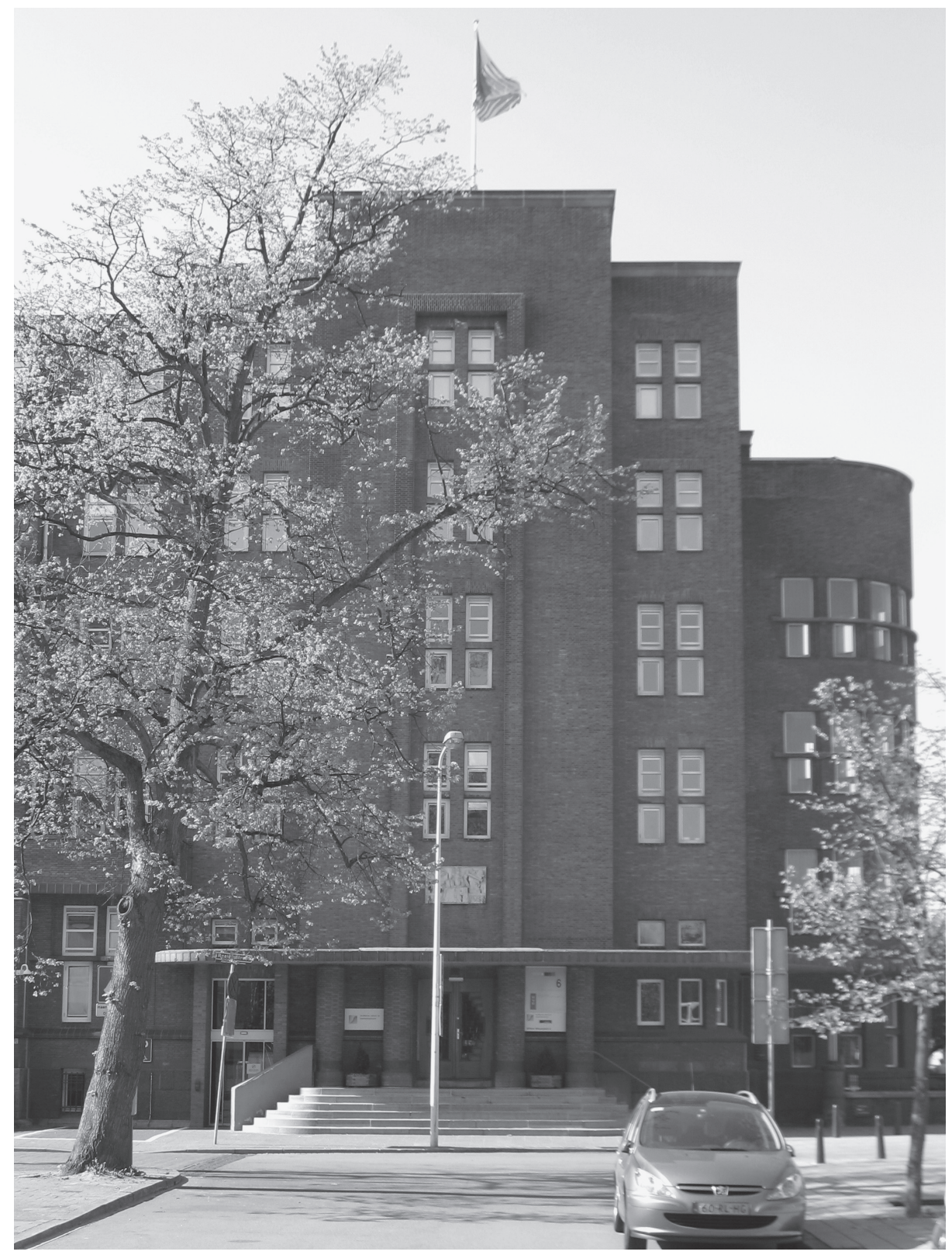

Fig. 2.1 - Het Ruimtelijk Planbureau 
(De volgende beschrijving is een door mij gestileerd verhaal, waarin ik gebruik maak van verschillende observatieverslagen).

Het is een frisse herfstochtend. Na een lange treinrit en een frisse wandeling door het Haagse bos zie ik aan de andere kant van een verkeersplein het gebouw liggen dat ik herken van een foto: Het Ruimtelijk Planbureau (RPB) (zie figuur 2.1). slechts gescheiden door het Haagse bos bevindt dit planbureau zich dichtbij, doch op gepaste afstand van, de ministeries. In deze locatie lijkt de bijzondere relatie tussen de Nederlandse planbureaus en de ministeries te worden weerspiegeld. Zü hebben onafhankelijkheid hoog in het vaandel staan en willen zelf kunnen bepalen welke thema's en onderwerpen zÿ aansnijden en analyseren. Anderzïds staan de planbureaus dicht bÿ de ministeries en willen zij beleidsrelevant zijn en een bijdrage leveren aan strategische beshitvorming.

Als ik het verkeersplein oversteek, valt mij op dat het gebouw waarin het $R P B$ is gehwisvest er ouderwets en gedateerd witziet. Dit is verraderlijk. Het RPB is namelijk opgericht op 1 januari 2002 en is daarmee het jongste van de vier Nederlandse planbureaus. Als ik het gebouw binnenloop zegt een vriendelijke stem: "Goedemorgen". Achter een balie zit een receptionist. Hÿ vraagt naar mijn naam en voor wie ik kom. Ik noem mün naam en die van één van de medewerkers van het planbureau. Als zï van mïn aanwezigheid op de hoogte is gesteld en ik een bezoekerspasje in ontvangst heb genomen, wÿst de receptionist me de weg naar de lift en zegt: "Derde verdieping". Ik stap de lift in. Als de lift op de derde verdieping haar deuren opent, kijk ik even om mï heen. voordat ik de lange gang links van de lift inloop, beshit ik even wit het raam naar buiten te kijken om mij te kunnen oriënteren. Onder mï zie ik het verkeersplein dat ik zojuist ben overgestoken en daarachter het Haagse bos. Als ik nog verder weg kijk dan zie ik zelfs een aantal kantoorgebouwen van de ministeries. Verder zie ik woonwijken, straten, bomen, kantoren, parkjes, nog meer verkeerspleinen... Terwijl ik mï realiseer dat dit een prachtige locatie is voor een institunt dat in Nederland de ruimtelïke ordening verkent, word ik opgeschrikt door de medewerker van het planbureau. Ze zegt: "Ha, de onderzoeker wit Maastricht, hoe gaat het? Wat ben je lekker vroeg". Ze vraagt of ik een rondleiding wil door het gebouw. We beginnen onze wandeling over de derde verdieping en mijn gids legt wit wat we zien: links het secretariaat, iets verder rechts de koffiernimte, dan de damestoiletten....

Mÿn gids wordt aangeklampt door een collega en zü raken even aan de praat. Mÿn blik valt op een rek waarin verschillende, kleurrijke RPB-rapporten zijn nitgestald (zie figuur 2.2) en al lezende realiseer ik mï hoe breed het werkterrein van het RPB is: de rapporten beslaan een breed spectrum aan maatschappelijke ontwikkelingen en hun effecten op de ruimtelijke ordening van Nederland en niet alleen in heden, maar ook in de toekomst. 


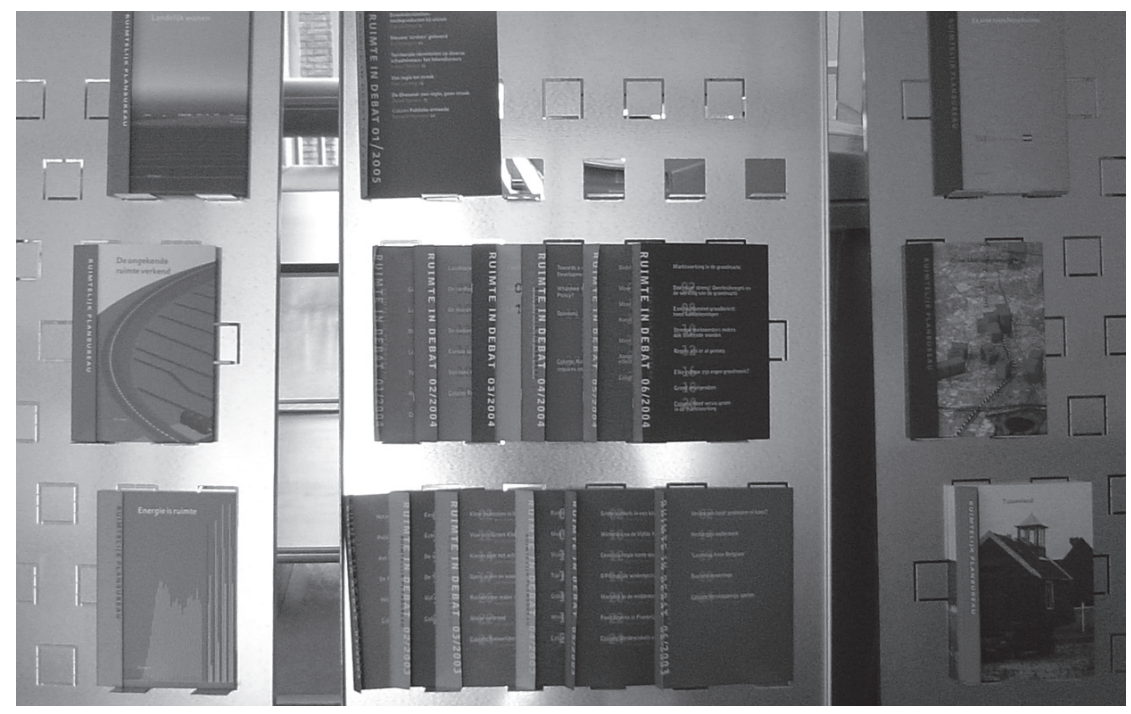

Fig. 2.2 - Uitgestalde RPB-rapporten

Dan wordt de rondleiding vervolgd. Mÿn gids klopt op een deur van éen van de kamers en zegt dat de man in deze kamer betrokken is byj het project dat ik wil

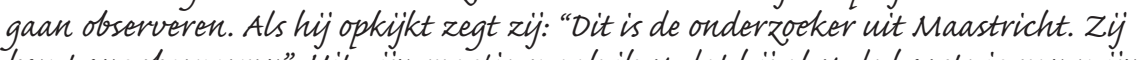
komt ons observeren". Uit zijn reactie maak ik op dat hij al op de hoogte is van mijn komst. Ik leg wit dat ik wil begrÿpen hoe toekomstverkenningen worden gemaakt en dat ik waarschijnlijk mee zal lopen met hun project. Als de term 'observeren' valt, zegt hï plagend, maar ook enigszins verontrust: "je gaat me toch nict op de vingers kijken, toch?". Ik probeer hem gerust te stellen door te zeggen dat ik dit onderzoek doe nit fascinatie en bewondering voor hun werk en dat ik wil begrÿpen hoe zoiets ingewikkelds als het verkennen van de toekomst kan worden gedaan ${ }^{15}$. Hÿ lijkt gerustgesteld. Ik zeg dat ik hem mu niet langer van zïn werk wil houden en dat we elkaar vanmiddag nog bij de projectbijeenkomst zullen zien. Ik neem afscheid en als ik nog even achterom kijk, staart hï alweer geconcentreerd naar zijn beeldscherm.

Nadat we weer een aantal werkkamers zïn gepasseerd, wïst mün gids naar de archiefruimte van het planbureau. Ik zie een aantal stellingen met tïdschriften en beshit daar op een later tijdstip eens rustig te gaan neuzen. Dan lopen we verder. Links en rechts zie ik nog meer werkkamers. Als we de lange gang helemaal zïn nitgelopen

\footnotetext{
${ }^{15}$ De fascinatie voor het onvermogen van de mens om de toekomst te voorspellen versus het verlangen de toekomst te kennen was het startpunt van het onderzoeksprogramma 'Methodologie voor toekomstverkenning' waar mijn proefschrift onderdeel van uitmaakt (van Asselt, 2003).
} 
wÿst ze in de hoek naar de vergaderrwimtes. Rechts zie ik een tweede gang met nog meer werkkamers. Mÿ valt op dat bijna alle deuren open staan. Vanuit de kamers klinkt zo nu en dan het zachte geluid van overleggende kamergenoten, typende vingers en telefoongerinkel. Op het secretariaat wordt gelachen.

Als we het einde van de gang hebben bereikt, neem ik afscheid van mijn gids en bedank haar voor de rondleiding. Ik beshit te gaan zitten op het rode bankje bij de koffiemachine om mïn indrukken van die ochtend op papier te kunnen zetten. Ik heb mijn aantekenschrift op mijn schoot gelegd en op de bank naast mï mijn opnameapparatuur en een fototoestel. Ik schrijf boven aan een lege pagina in mïn schrift: "Toekomstverkennen bij het Ruimteliyk Planbureau".

Den Haag, 19 maart 2002: 's Ochtends woon ik een projectbijeenkomst bÿ van een scenarioproject dat door de betrokkenen 'SCENE' wordt genoemd. Ik zit aan de ovale tafel in het midden van de vergaderruimte. Als ook de andere genodigden zich installeren, meldt de voorzitter dat iedereen er is. Zü heet iedereen welkom bÿ deze bijeenkomst van wat zï noemt het "kernteam", stelt mï en mïn co-promotor voor als "gast" en deelt alle aanwezigen mee dat wÿ vanaf heden vaker zullen aanschiven bï hun bijeenkomsten. Vervolgens stelt zij voor een voorstelrondje te doen en geeft mij als eerste het woord. Ik leg nit dat ik bezig ben met een promotieonderzoek aan de Universiteit van Maastricht en in mïn proefschrift wil vertellen over de praktijk van toekomstverkennen. Ook zeg ik dat we, om de praktijk van binnenuit te kunnen beschrijven, etnografisch onderzoek doen en leg wit dat dit betekent dat we vaak aanwezig zullen zïn bü hun projectbijeenkomsten, vragen zullen stellen en dat wï onze observaties regelmatig aan hen voor zullen leggen.

We zitten om de tafel met vier mannen en drie vrouwen. De voorzitter en de man naast haar stellen zich beiden voor als "projectleider" van dit project. Vier anderen stellen zich voor als "deelprojectleider" van respectievelijk vier deelprojecten, namelijk "Internationaal", "Stedelijke netwerken", "Stad en Land" en "Onderlaag". Ik constateer dat parallel aan het kernteam blijkbaar vier deelprojectteams werken aan de scenariostudie. De laatste aanwezige stelt zich voor als "projectsecretaris" en notuleert tÿdens de vergadering. Samen blÿken de aanwezigen verschillende instituten te vertegenwoordigen. Dus, hoewel het project wordt aangemerkt als een "RPBproject", zïn maar drie van de zeven kernteamleden daadwerkelijk werkzaam bij het Ruimtelijk Planbureau. Eén tockomstverkenner werkt voor een ander planbureau, éen voor een Ministerie, éen bï een adviesbureau en de laatste bij een detacheringbureau. Als iedereen zich heeft voorgesteld, stelt de voorzitter voor over te gaan tot de orde van de dag. Tüdens de vergadering blijkt dat deze "orde" bestaat nit het doen van mededelingen, het rapporteren van voortgang (en knelpunten) in de deelprojecten en het maken van afspraken voor de volgende bijeenkomst. 
Door verwïzingen naar "het integrale project" en "deelprojecten", "eerdere bijeenkomisten", "nieuwe afspraken" en "terngkoppelingen" maak ik op dat het project zich op verschillende locaties, op verschillende momenten en in verschillende samenstellingen afspeelt. De toekomstverkenners spreken de ambitie nit om aan te shiten bÿ zowel activiteiten bÿ andere instituten, andere toekomstverkenningen, verschillende wetenschappelijke tradities als verwachtingen van "oporachtgevers", "beleidsmakers" en "maatschappelijke doelgroepen". Dit maakt mï ervan bewust dat deze toekomstverkenners onderdeel zïn van een complex, sociaal netwerk dat ver buiten de muren van het $R P B$ reikt.

Ik Mister naar de discussies die de toekomstverkenners onderling met elkaar voeren en probeer nit deze gesprekken op te maken waar het in de toekomstverkenning allemaal om draait. Ik lees in éen van de vergaderstukken die aan het begin van de bijeenkomst zijn verspreid dat SCENE staat voor "SCEnario's voor NEderland' en dat het de bedoeling is vier "ruimtelijke scenario's" te ontwikkelingen met een tÿdshorizon tot 2030. Eén van de termen die mïn aandacht trekt is "indicatoren". Uit het verhaal van de projectleider die verantwoordelijk blijkt voor het "integrale project" maak ik op dat de term indicatoren verwïst naar zes door het projectteam geidentificeerde thema's, namelijk "politiek en bestuur", "economie", "technologie", "sociaal-cultureel", "milieu" en "demografie". Deze thema's, die in alle deelprojecten terng lijken te komen, lïken te verwizen naar brede maatschappelijke onderwerpen, zoals "klimaatverandering", "immigratieproblematiek", en "de vergrijzing". De toekomstverkenners lijken zich dus bezig te houden met grote maatschappelyke thema's.

Noties als "iteraties", discussies over "integratieslag" en vragen als "hoe neem je trends in indicatoren mee in scenario's?" wekken de indruk dat de scenario-exercitie alles behalve een routineklus is. Het werk van de toekomstverkenners lijkt eerder een gezamenlijke zoektocht dan het doorlopen van een vooraf bepaald stappenplan. Geen van de keuzes die worden gemaakt lijkt vanzelfsprekend en iedere genomen stap lijkt te worden genomen nadat voors en tegens in het projectteam zijn afgewogen. Tÿdens deze vergadering lijken de verkenners onderling of te tasten hoe verder te gaan. En hoewel ze verwïzingen maken naar eerdere toekomstverkennende projecten waarin zÿ in het verleden betrokken waren, geven zï mï het gevoel dat zï zich ook begeven op onbekend terrein. Toekomstverkenners wekken de indruk het project niet te beschouwen als een standaardproject, maar eerder als een bÿzondere exercitie of zelfs ontdekkingsreis.

Maar waar draait het in deze toekomstverkenning om? Waar gaat de ontdekkingsreis naar toe? Uit wat de verkenners tÿdens deze bijeenkomst vertellen, krïg ik de indruk dat zÿ allemaal een andere bestemming hebben gekozen of toegewezen hebben gekregen. uit de verschillende verhalen maak ik op dat het deelteam "Internationaal" het vizier richt op Europa en wil begrijpen welk effect de diverse maatschappelijk ontwikkelingen hebben op de Europese ruimte. Voor het deelteam "stedelijke Netwerken" is het nationale 
schaalniveau de belangrïkste bestemming. Dit deelteam wil bekÿken hoe stedelijke netwerken als "KAN"(Knooppunt Arnhem - Nÿmegen) en "Brabantstad" zich in de toekomst zullen ontwikkelen. Het derde deelteam reist of naar een lager schaalniveau om verschillende overgangsgebieden tussen stad en land te bekijken. En het deelteam "Onderlaag" doet vijf verschillende stroomgebieden aan, namelijk de Noordzee, het IJsselmeer, Maas-Rïn, Schelde en Eems. De projectleiders, tenslotte, doen Nederland in vogelolucht, en werpen of en toe een blik over de Nederlandse grens naar de rest van Europa. Uit de discussies maak ik op dat alle reisverslagen samen "gëntegreerd" zullen worden in vier "scenario's" die beleidsmakers en andere "mensen in het veld" inzicht moeten geven in "het langetermïnverloop van de maatschappelyke ontwikkelingen" en mogelijke ruimtelijke effecten en knelpunten op verschillende schaalniveaus. 


\subsection{Een relatieve buitenstaander in de praktijk van toekomstverkennen}

Toekomstverkennen lijkt in veel opzichten op de kunst van maken van schepen in flessen. Het is niet alleen een kunde, maar ook een kunst. Om te komen tot toekomstverkenningen is gedegen vakmanschap nodig, maar zonder kunstige trucs zal een toekomstverkenner er niet in slagen kennis over de toekomst te 'construeren'. Een buitenstaander krijgt in de regel niet veel inzicht in het proces van toekomstverkennen. Afwegingen, de geschiedenis van totstandkoming, wat gemakkelijk en wat moeilijk ging en waar misschien tegenstrijdigheden zaten, worden meestal geen onderdeel van het officiële historische narratief. Achteraf lijkt het resultaat een vanzelfsprekendheid (zie ook Hoofdstuk 1). De trucs zijn alleen zichtbaar als er bewust aandacht gegeven wordt aan de kunst van het verbinden van de 'stokjes', de 'draden' en de 'lijm' van waarmee toekomstverkenners de schepen van toekomstkennis opbouwen.

Op 19 maart 2002 was ik voor het eerste getuige van het soort werk dat toekomstverkenners bij het RPB 'achter de schermen' verzetten om tot een verkenning van de toekomst te komen. Hoewel ik tijdens deze bijeenkomst voor mijn gevoel een en ander te weten was gekomen over de praktijk van toekomstverkennen, keerde ik terug naar Maastricht met nog meer vragen dan waar ik mee gekomen was: Hoe vinden toekomstverkenners houvast terwijl richtlijnen, stappenplannen en routine ontbreken? Van welk complex en sociaal netwerk zijn zij onderdeel en hoe beïnvloedt dit netwerk het werk van de toekomstverkenners? Hoe gaan ze om met het bestaan van verschillende perspectieven, deelresultaten en inzichten en hoe integreren zij deze in een gezamenlijk product?

Het observeren van de dagelijkse praktijk van toekomstverkenners en het zelf getuige zijn van het toekomstverkenningsproces was voor mij een manier om te leren hoe toekomstverkenners kennis over de toekomst produceren. Naar de onderzoeksstijl waarbij de onderzoeker de praktijk niet alleen van binnenuit wil begrijpen, maar ook wil beschrijven wordt ook wel verwezen met de term 'etnografie'. Etnografisch onderzoek heeft zijn wortels in een antropologische traditie waarin verre, exotische culturen traditioneel werden onderzocht doordat de onderzoeker zelf voor enige tijd onderdeel uitmaakt van de setting die wordt beschreven en onderzocht (Hammersley \& Atkinson, 1995). Het is een onderzoeksstijl waarbij de onderzoeker zich verplaatst in het "perspective of a stranger" (Woolgar, 1988), die voor het eerst in aanraking komt met een cultuur.

Eind jaren zeventig verschenen de eerste zogenaamde laboratoriumstudies, die zich baseerden de etnografische traditie. In plaats van "exotische" culturen te onderzoeken, zochten zij het dichter bij huis en vestigden zij de aandacht op de productie van kennis in laboratoria, "the root where knowledge is produced" (Knorr-Cetina, 1995). Deze aanpak werd een belangrijk onderzoeksspoor naast de historische gevalstudie die in dezelfde 
periode aan populariteit won onder invloed van (Kuhn, 1970). Eén van de eerste studies die de constructie van wetenschappelijke feiten op basis van etnografisch onderzoek beschreef was Laboratory Life van Latour \& Woolgar (1979). Door wetenschap te zien als cultureel fenomeen en wetenschappers van dag tot dag te volgen konden zij laten zien hoe wetenschappers actief "feiten" construeren. Daarna volgden er veel soortgelijke etnografische studies waarin verschillende aspecten van kennisproductie werden belicht. Toonaangevende studies zijn: The manufacture of knowledge (Knorr-Cetina, 1981), Opening Pandora's Box (Gilbert \& Mulkay, 1984); Art and Artifact in Laboratory Science (Lynch, 1985) en Beamtimes and Lifetimes (Traweek, 1988). De vraag die centraal staat in deze etnografische studies naar kennisproductie is: "hoe kunnen verklaren dat onderzoekers ondanks 'interpretatieve flexibiliteit'16 toch overeenstemming bereiken" (Hagendijk, 1996). Of, met andere woorden, hoe creëren wetenschappers die regelmatig worden geconfronteerd met "a seething mass of alternative interpretations" (Latour \& Woolgar, 1986: 36) orde in complexiteit? Kennisproductie wordt in laboratoriumstudies dus behandeld als een construerende activiteit, wat impliceert dat orde actief door wetenschapsbeoefenaars wordt gecreëerd. In laboratoriumstudies is vaak het uitgangspunt dat, hoewel wetenschappelijke feiten worden geconstrueerd, zij juist niet geconstrueerd lijken te zijn en dat alle betrokkenen ervan overtuigd zijn dat het uiteindelijke resultaat van onderzoek de enige mogelijke en vanzelfsprekende uitkomst is:

".. once the end product, an inscription, is available, all the intermediary steps which made its production possible are forgotten. The diagram or sheet of figures becomes the focus of discussion between participants, and the material process which gave rise to it are either forgotten or taken for granted as being merely technical matters" (Latour \& Woolgar, 1979: 63).

In laboratoriumstudies wordt op zoek gegaan naar het verhaal achter zogenaamde wetenschappelijke "black-boxes"17. Etnografen vertellen andere verhalen dan het

\footnotetext{
${ }^{16}$ Deze term werd geïntroduceerd door Collins (1981). Hij stelde dat welke interpretatie onderzoekers geven aan metingen en wetenschappelijke experimenten een kwestie is van onderhandeling (zie ook (Hagendijk, 1996)).

${ }^{17}$ Deze term is afkomstig van een definitie van Wiener uit 1961, waarin de "black box" wordt gecontrasteerd met een "white box": "I shall understand by a black box a piece of apparatus, such as fourterminal networks with two input and two output terminals, which performs a definite operation on the present and past of the input potential, but for which we do not necessarily have any information of the structure by which this operation is performed. On the other hand, a white box will be a similar network in which we have built in the relation between input and output potentials in accordance with a definite structural plan for securing a previously determined input-output relation" (geciteerd in Jordan \& Lynch (1992)). Een "black box" verwijst dus naar wetenschappelijke feiten of technologische artefacten waarvan de interne werking impliciet is omdat de interne werking als vanzelfsprekend wordt geacht. Latour en Woolgar (1986) gebruiken het werkwoord "blackboxing"
} 
definitieve, lineaire en sterk vereenvoudigde verhaal dat in de beschrijving van de totstandkoming van wetenschappelijke feiten domineert en waarin de rol van alternatieve uitkomsten en perspectieven wordt gemarginaliseerd. In etnografische studies wordt de rol van de onderzoekers (als individuen en als onderdeel van een wetenschappelijke gemeenschap) centraal gesteld en geprobeerd het mysterie van wetenschapproductie te ontrafelen door de dagelijkse activiteiten van wetenschappers ('science in the making') op de voet te volgen. Woolgar karakteriseert de etnografische aanpak als "a way of highlighting the taken-for-granted practices (..) under study" (Woolgar, 1988). Middels de etnografische methode van "talking to and interaction with people" (Hess, 2001) en "temporary membership" (Star, 2002) wordt geprobeerd de symbolische wereld en het sociale leven van andere culturen te doorgronden en aan de buitenwereld te ontsluiten: "By observing an institution from the inside, by participating in meetings and other rituals or by following the insiders through their everyday life at work, the mixture and interwovenness of all these many discourses become apparent" (Wodak, 1996: 10).

Een kenmerk van participerende observatie is de ambigue relatie tussen de onderzoeker en het onderzochte, omdat een onderzoeker die de praktijk van binnenuit wil begrijpen idealiter een 'insider' is en tegelijkertijd een 'outsider'. Zo stellen Glaser \& Strauss (1967), grondleggers van het zogenaamde 'grounded theory', dat: "He has been sufficiently immersed in this world to know it, and at the same time has retained enough detachment to think theoretically about what he has seen and lived through" (226). Enerzijds probeert de onderzoeker, door zich in een andere cultuur onder te dompelen en onderdeel te worden van die dagelijkse praktijk, de vreemde cultuur te zien vanuit het perspectief van die cultuur zelf en inzicht te geven in verschillende interpretaties en de veelzijdigheid van een cultuur: "The idea is that more is to be gained from being on the spot than when attempting interpretation from a secondary perspective" (Star, 2002: 109), zoals bijvoorbeeld in archiefonderzoek of interviews. Om een vreemde cultuur te kunnen ontsluiten is begrip van de taal, concepten, categorieën, praktijken, regels, enzovoort, zoals die door de leden van de cultuur worden gebruikt cruciaal (vergl. van Maanen (1988: 13)).

Anderzijds, moeten etnografen voorkomen dat zij te veel socialiseren met de cultuur die zij observeren en de afstand verliezen om kritisch te kunnen analyseren (Bal, Bijker, \& Hendriks, 2002: 338); (Ashmore, Myers, \& Potter, 1995) en alleen nog maar als lid van die cultuur ('native') kunnen spreken. Naar dit gevaar wat steeds op de loer ligt verwijzen verschillende auteurs met de term "going native" (Schwartz \& Schwartz, 1955); (Hammersley \& Atkinson, 1995). Etnografen typeren zichzelf als "marginal natives" (Freilich, 1970) of als "professional strangers" (Agar, 1980). Voor etnografisch onderzoek van wetenschappelijke praktijken is er volgens de wetenschapssocioloog Woolgar 
een bijkomend probleem omdat de etnograaf, als lid van de brede wetenschappelijke gemeenschap, per definitie een "quasi-believer" is ${ }^{18:}$ "In practical terms this problem amounts to learning when to ask the right questions and, perhaps more importantly, recognizing and noting the point when the answers are no longer surprising" (Woolgar, 1988: 86). Voor mijn onderzoek is het bewust zijn van dit probleem zeker relevant, omdat ik en mijn mede-etnograaf en onderzoeksleider voor wij dit onderzoek begonnen zelf als onderzoeker betrokken waren bij verschillende toekomstverkennende projecten ${ }^{19}$. Om toch voldoende afstand te houden tot de bestudeerde cultuur en om kritische reflectie te stimuleren zijn alle verslagen door de tweede onderzoeker van het onderzoek gelezen en van vragen en commentaar voorzien. De etnografische momenten die a priori een cruciaal karakter leken te hebben zijn steeds door beide onderzoekers geobserveerd. Daarnaast heb ik tijdens het onderzoek verschillende reflectiemomenten ingebouwd. Zo heb ik mijn inzichten op verschillende momenten aan collega (wetenschap)-onderzoekers in binnen- en buitenland voorgelegd: tijdens twee binnen het onderzoeksprogramma georganiseerde peer-review workshops, tijdens bijeenkomsten van onze onderzoeksgroep BOTS binnen de faculteit der Cultuurwetenschappen, tijdens AIO-discussies van de faculteit en de onderzoeksschool WTMC, tijdens diverse nationale en internationale workshops en congressen en tijdens lunchlezingen bij het planbureau en het 'Institute for the Future' in California. Ook mijn werkbezoek aan Prof. Star en en Prof. Bowker van het 'Center for Science, Technology \& Society' (Santa Clara University, $\mathrm{CA}$ ) hielpen mij bij het nemen van afstand.

Wat betreft de rol van de onderzoeker die de praktijk van binnenuit wil begrijpen wordt vaak een continuüm geschetst dat loopt van volledige participatie tot volledige observatie (Pearsall, 1965); (Spradley, 1980); (Collins, 1984). Mijn rol als etnograaf kan het best worden getypeerd als 'participerend observant'. Ik wilde namelijk zo veel mogelijk de 'levensechte' praktijk observeren zonder actief te interveniëren. Bij het observeren was steeds de vuistregel dat ik geen werk uit handen wilde nemen, dat ik in discussies wel

\footnotetext{
${ }^{18}$ Organisatie-antropologe Barbara Czarniawska verwijst naar deze vorm van etnografisch onderzoek met de term 'anthropology of doppelganger'. Zij zegt hierover: "The other does not always live in an exotic country or even in an immigrant ghetto (..). Organisations and management scholars study their equals, often their superiors. They study the ways in which things are done by people with the same education, coming from the same tradition, and advancing the same claims about knowledge validity as themselves" (Czarniawska, 1997: 5).

${ }^{19}$ In de periode van september 1999 tot juli 2000 was ik stagiaire in het door de Europese Unie gefinancierde scenarioproject 'Visions for a sustainable Europe' (van Asselt, Rotmans, \& Rothman 2005). Daarna was ik als onderzoeker betrokken bij het ontwikkelen van toekomstbeelden voor het stroomgebied van de Rijn en de Maas (Middelkoop et al., 2004). Tevens heb ik in deze periode ervaring opgedaan met het proces van toekomstverkennen in verschillende adviesprojecten en was ik betrokken bij het ontwikkelen van een gezelschapsspel waarmee aan de hand van verschillende scenario's toekomststrategieën verkend kunnen worden (Carton \& Karstens, 2002).
} 
vragen en ideeën inbracht, maar zonder te willen overtuigen en dat ik mij bij reflecties en terugkoppeling terughoudend opstelde, en sowieso vertraging inbouwde.

Doordat ik niet actief deelnam aan de discussies en geen duidelijke bijdrage leverde aan de toekomstverkenningen, konden de betrokken toekomstverkenners mijn rol soms moeilijk duiden. Als zij mij zagen bij bijeenkomsten, door het gebouw zagen lopen of zagen discussiëren tijdens de lunchpauze beschouwden zij mij soms als 'nieuwe collega'. Als ik werd voorgesteld aan de medewerkers bij het Ruimtelijk Planbureau dan was ik meestal 'de onderzoeker uit Maastricht'. Als ik aanschoof bij discussies met externe onderzoekers en adviseurs werd ik neergezet als 'de externe, onafhankelijke onderzoeker die het project monitort en evalueert', waarmee men de open en reflexieve houding van het planbureau leek te willen benadrukken. Op momenten dat spanningen tussen toekomstverkenners escaleerde, was ik de neutrale partij, een vertrouwenspersoon en een luisterend oor. En als projecten waren afgerond en men terugkeek op het proces, werd ik gezien als degene met het overzicht als 'onafhankelijke toeschouwer'.

Onze aanwezigheid werd echter niet altijd als positief ervaren. Sommige toekomstverkenners waren bang dat wij een 'onthullend-kijkje-achter-de-schermen' zouden geven en eventuele 'misstanden' aan de orde zouden brengen. Anderen verwachtten van ons dat wij ter plekken praktische oplossingen zouden aandragen voor problemen waar zij tegenaan liepen. Ook kregen wij 'ongeduldige' vragen over wanneer wij dan eindelijk onze inzichten met hen konden delen.

\subsection{Een relatieve nieuwkomer in de praktijk van toekomstverkennen}

Dat het werk van de toekomstverkenner mij niet helemaal vreemd was toen ik aan dit onderzoek begon, betekende echter niet dat de door mij geobserveerde praktijken van toekomstverkennen vanaf het eerste moment vertrouwd was. Het werk van toekomstverkenners is zelfs voor een ingewijde nieuwkomer vaak moeilijk te begrijpen. Allereerst werd ik als relatieve nieuwkomer geconfronteerd met het gebruik van disciplinair jargon uit de wereld van de ruimtelijke ordening - hetgeen voor mij een nieuw onderzoeksterrein was - en met afkortingen en termen die afkomstig waren uit verschillende disciplinaire werelden. In elk van de projectteams was een breed spectrum aan wetenschappelijke disciplines vertegenwoordigd, waaronder planologie, sociale geografie, fysische geografie, economie en econometrie, demografie en bestuurskunde. Elk projectlid bracht zijn of haar eigen wetenschappelijke traditie en jargon mee in het project. De mensen die de verkenningen uitvoeren nemen vaak een schat aan ervaring en routine - opgedaan in eerdere verkenning-exercities - mee naar nieuwe studies. Tijdens projectbijeenkomsten worden impliciete toespelingen of expliciete verwijzingen 
gemaakt naar dit verleden, waar een nieuwkomer in het begin vaak geen weet van heeft.

Daarbij is het werk van toekomstverkenners voor een buitenstaander moeilijk te doorgronden, omdat hij/zij onderdeel wordt van een praktijk die zich in de tijd heeft ontwikkeld tot wat deze op dat moment is (Lave \& Wenger, 1991). Veel beslissingen met betrekking tot de aard, inbedding en opzet van de studie worden dus al lang voordat het projectteam in actie komt gemaakt of gevormd. Geen enkele toekomstverkenning is helemaal nieuw.

De door mij geobserveerde toekomstverkennende projecten hadden bijvoorbeeld een relatief lange aanlooptijd die zich steeds buiten mijn gezichtsveld heeft voltrokken (en ook vaak buiten dat van deelnemende toekomstverkenners!). In deze aanloopfase onderhandelen opdrachtgevers (meestal de planbureaudirectie) en de opdrachtnemers (de projectleider(s) / coördinator(en) in spé) meestal achter gesloten deuren met elkaar over zaken als de doelstelling, de interne en externe positionering, de opzet, de looptijd en de financiële kant van het nieuw te starten toekomstverkenningsproject. Een aantal zeer cruciale beslissingen wordt dus al ver voor de officiële start van het project genomen.

Met name voor beleidsgerichte toekomstverkenningen geldt dat bewust of onbewust, expliciet of impliciet, wordt voortgebouwd, of juist afstand genomen van, eerdere toekomstverkenningen. In het SCENE-project werd door het 'nieuwe' RPB bijvoorbeeld expliciet afstand genomen van de scenariotraditie van de 'oude' Rijksplanologische Dienst. In het WLO-project, daarentegen, werd juist naar continuïteit gezocht met eerdere verkenningen en positioneerden de verkenners het project expliciet in de CPB-traditie ${ }^{20}$. In toekomstverkenningen zijn tal van sporen uit het verleden terug te vinden. In een recente CPB scenariostudie Four Futures of Europe (CPB, 2003) geven de auteurs te kennen dat de scenario's die zij beschrijven "... have some overlap with scenarios that have been developed before" (173). Toekomstverkenners blijken vaak te zoeken naar afstemming met andere toekomstverkennende projecten die zich binnen de planbureaus voltrekken en met beleidsnota's die tijdens het verkenningstraject verschijnen. Het zoeken naar, en maken van continuïteit (of discontinuïteit) met, andere toekomstverkenningen lijkt een manier die toekomstverkenners inzetten om geloofwaardigheid te creëren. Eerdere verkenningen zijn vaak richtinggevend voor nieuwe verkenningen. Zo wordt in het WLO-project expliciet voortgebouwd op de studies Scanning the Future, Economie en Fysieke Omgeving (EFO) en Four Futures of Europe van het CPB. Over deze studies wordt gezegd dat ze "algemeen worden (..) beschouwd

${ }^{20}$ Er wordt vaak beweerd dat de scenario's van het CPB in de wereld van het toekomstverkennen een hegemoniale positie innemen. Schooneboom (2003) verwijst naar de "inteeltfunctie" van CPBscenario's wanneer hij stelt dat in vrijwel alle scenarioverkenningen gebruikgemaakt werd van de CPB-scenario's

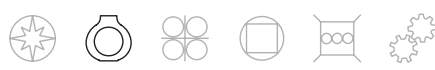


als evenwichtig, betrouwbaar en onafhankelijk" (WLO Plan van Aanpak, 2003: 1). Eén van de WLO-toekomstverkenners beschouwt de "eerdere studies" van het CPB "als kapstok" voor de nieuwe studie en een ander legt uit dat de studie wat hem betreft "iets soortgelijks" wordt als de EFO-studie. De eerste maanden van de WLO-studie wordt EFO zelfs als werknaam gebruikt voor het project. Binnen de werkgroep Energie wordt het EFO-hoofdstuk over Energie direct gebruikt als format door lege tabellen en grafieken opnieuw in te vullen met de uitkomsten van nieuwe analyses. Eén van de onderzoekers merkt op dat "beargumenteerd wordt afgeweken van het 'Four Futures'-beeld" (WLO projectbijeenkomst, 23 augustus 2004).

Met andere woorden, onbekendheid met het specifieke verleden van mensen, instituten, projecten, etc. maakt voor een nieuwkomer moeilijk te volgen, laat staan te duiden, waar het in de dagelijkse praktijk van toekomstverkenningen over gaat. Er is, met andere woorden, geen echt beginpunt. Als etnograaf stapte ik op een rijdende trein en moest ik op de een of andere manier proberen te achterhalen wat voorafgegaan was. Tal van aannames, verwachtingen en kaders van betekenisgeving blijven vaak voor lange tijd impliciet, waardoor het voor een nieuwkomer moeilijk te volgen is wat er gebeurt en waarom dat gebeurt, zelfs als de onderzoeker, zoals in mijn geval, enigszins vertrouwd is met de praktijk van toekomstverkennen.

Een deel van de gemiste geschiedenis kon ik achterhalen door projectdocumentatie, zoals notulen, gespreksverslagen, verschillende versies van plannen van aanpak en startnotities en verschillende werkdocumenten, te bestuderen. Deze stukken gaven echter meestal alleen inzicht in de beslissingen: hoe men tot beslissingen was gekomen was vaak niet terug te vinden in de officiële documentatie. Ik ervoer dat toekomstverkenners in de planbureaupraktijk in de regel weinig tijd hebben voor een reflexieve evaluatie. Daarbij geven toekomstverkenners vaak aan dat hun beleidsmakers in de regel meer geïnteresseerd zijn in de inhoudelijke conclusies dan in de methodologische aspecten van het onderzoek (vergl. Ester, Geurts, \& Vermeulen (1997)) Het proces van toekomstverkennen en de gehanteerde methodologie zijn mede daarom slecht uit de officiële rapporten en publicaties af te leiden (zie bijvoorbeeld Dobbinga (2001) en van Asselt (2003)). Wat de lezer wel onder ogen krijgt, is een gestileerd verhaal waarin, als er al het een en ander over het onderlinge proces expliciet is vastgelegd, alleen de allerbelangrijkste stappen en keuzes worden verantwoord ${ }^{21}$. Delen van de geschiedenis heb ik bij stukjes en beetjes geleerd door wat de toekomstverkenners die ik observeerde manifest maakten in het heden, hetzij spontaan of naar aanleiding van mijn vragen.

\footnotetext{
${ }^{21}$ En dit is zeer begrijpelijk. Ook mijn onderzoeksproject was een complex en alles behalve lineair proces. En ook ik wil de lezer niet lastigvallen met alle omwegen die ik de afgelopen vier jaar heb genomen om uiteindelijk hier terecht te komen.
} 


\subsection{Dataverzameling}

Ik heb in de periode van december 2001 tot en met december 2004 en minder frequent en systematisch in 2005 en 2006 drie toekomstverkennende projecten van het Ruimtelijk Planbureau geobserveerd: SCENE, WVR en WLO (zie hoofdstuk 1; zie bijlage 1 voor een overzicht van observatiemomenten). Deze drie toekomstverkenningen hadden elk een looptijd van 1,5 tot 2 jaar. Tijdens de veldwerkperiode hebben we ongeveer honderd vergaderingen bijgewoond. Ik heb ervoor gekozen geen onderdeel te worden van het projectteam, maar als 'relatieve buitenstaander' de RPB-praktijk van toekomstverkennen te observeren ${ }^{22}$. Dit betekende dat ik niet fulltime onderdeel was van de praktijk, maar selectief observatiemomenten koos. Afhankelijk van de projectdynamiek was het veldwerk meer of minder intensief. Op momenten dat er veel gebeurde in de projecten, was ik soms een aantal dagen en een enkele keer twee tot drie weken aaneengesloten aanwezig. In relatief rustige periodes woonde ik slechts vergaderingen bij en praatte ik na de vergaderingen met de toekomstverkenners over het project. Het nadeel van fulltime observeren gedurende de looptijd van het project is, dat het onmogelijk zou zijn geweest om meerdere gevalsstudies te behappen en deels parallel uit te voeren. Doordat ik niet fulltime aanwezig was, kon ik parallel aan het veldwerk voor het ene project werken en aan de analyse van de/het andere project(en). Bovendien blijkt het moeilijker om los van de waan van alledag te reflecteren op de observaties als de onderzoeker fulltime aanwezig is. Zo constateert Dobbinga (2001) bijvoorbeeld dat de informatievergaring met de tijd door haar intensieve betrokkenheid steeds moeilijker werd: "Zoals ik aanvankelijk als een tabula rasa onbeperkt van informatie werd voorzien, merkte ik in de loop van de tijd, dat naarmate ik meer kennis vergaard had, er minder met mij werd gedeeld. (..) Ik kwam tot het besef dat ik een speler was geworden in plaats van louter een onschuldige onderzoeker van buiten de organisatie". Een nadeel van onze observatiemethode - zo bleek - was dat ik, door de fysieke afstand tussen Maastricht en Den Haag soms niet in staat was om vergaderingen bij te wonen. Ook bleek soms (achteraf) dat de betrokken toekomstverkenners ons vergeten waren op de hoogte te stellen van op korte termijn geplande bijeenkomsten of ons vergaten uit te nodigen, omdat we niet continue in beeld waren. Tegelijkertijd geldt dat welke observatiemethode we ook zouden hebben gekozen, het nooit mogelijk was geweest om alle toekomstverkennende activiteiten te kunnen observeren. En niet in de laatste plaats door de complexe opzet van de toekomstverkennende projecten die ik observeerde. De projecten bestonden namelijk uit verschillende themagroepen die parallel en vaak op verschillende locaties in Nederland aan de uitwerking van verschillende deelthema's werkten. Bij het RPB is het namelijk niet ongewoon om expertise van buiten het planbureau in te huren en samen te werken met mensen van de andere planbureaus en planbureau-achtigen. Dit betekent dat ook toekomstverkenners zelf geen compleet overzicht hebben van wat zich op verschillende

\footnotetext{
${ }^{22}$ De meeste etnografen doen hun veldwerk 'fulltime' gedurende een bepaalde periode of meerdere perioden (vergl. Latour \& Woolgar (1979); Dobbinga (2001) en Mesman (2002)).
}

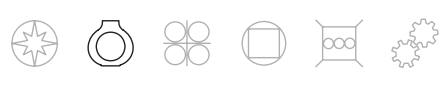


niveaus, locaties en gremia binnen toekomstverkennende projecten afspeelt. Zelfs onze sleutelinformanten bij het RPB hadden niet altijd het overzicht of waren niet betrokken, waardoor we soms afhankelijk waren van mensen die misschien wel van ons gehoord hadden, maar ons niet hadden ontmoet en maar beperkt op de hoogte waren van ons onderzoek en onze wens toekomstverkennende projecten te observeren. Hierdoor hebben we zelfs een heel toekomstverkennend project 'gemist'. Daarbij voltrok een aantal interacties zich buiten mijn gezichtsveld omdat toekomstverkenners veel discussies voeren en beslissingen nemen via e-mail. En in de WLO toekomstverkenning kregen wij geen toegang tot het internetplatform. Een aantal van deze virtuele discussies kon ik echter wel volgen vanuit Maastricht, hetzij doordat toekomstverkenners mij op verzoek op hadden genomen in hun e-maillijsten, hetzij doordat e-mails op eigen initiatief van de toekomstverkenners naar ons werden doorgestuurd.

Gezien de lange looptijd van onze observaties hebben wij het 'missen' van bijeenkomsten niet als problematisch ervaren. Door de relatief lange duur van ons veldonderzoek, door het parallel uitvoeren van meerdere gevalsstudies en door gebruik te maken van triangulatie ${ }^{23}$ van diverse dataverzamelingstechnieken (participatieve observatie, documentanalyse, diepte-interviews en 'member checking'24) was het mogelijk om inzicht te krijgen in dieperliggende patronen en structuren en om stabiliteit in mijn beeldvorming van de praktijk van toekomstverkennen te krijgen.

Gedurende de gehele periode van dataverzameling hebben de betrokken toekomstverkenners bereidwillig en openhartig meegewerkt aan het onderzoek. Zij verleenden mij toegang tot verschillende overlegvormen. Ik mocht niet alleen aanschuiven bij diverse projectbijeenkomsten, maar kreeg ook toegang tot een aantal planbureaubrede bijeenkomsten zoals een tweedaagse cursus 'projectmatig creëren'

\footnotetext{
${ }^{23}$ De term 'triangulatie' verwijst naar het gebruik van verschillende informatie- en databronnen en verschillende onderzoeksmethoden. De suggestie is dat door vanuit verschillende bronnen en op verschillende manieren gegevens te verzamelen de kennis van, en inzicht in, het studieobject kan worden vergroot (Yin, 1994); (Swanborn, 1981/1994).

${ }^{24}$ Voor al het empirisch onderzoek in het onderzoeksprogramma geldt dat we (gedoseerd) gebruik hebben gemaakt van zogenaamde 'member checks'. Dit wil zeggen dat we aan de personen die het aanging hebben gevraagd of zij het eens kunnen zijn met onze interpretaties: 'herkent u zichzelf in...'?'. Het voorleggen van onze interpretaties deden we in de vorm interview- of observatiesverlagen en middels het voorleggen van onze analyse-resultaten tijdens bilateralal contact, lunchlezingen en laten lezen van concept-publicaties en hoofdstukken. Soms gebeurde dit op verzoek van de toekomstverkenners zelf; soms omdat wij hen vroegen om feedback. Een conceptversie van hoofdstuk drie hebben we voorgelegd aan het SCENE-projectteam. Het commentaar op dit concepthoofdstuk is vervolgens verwerkt in een latere versie. De bevindingen in hoofdstuk 3, 4 en 5 zijn in diverse presentaties aan en discussies met de betrokken toekomstverkenners gepresenteerd en ook deze feedback is in latere versies verwerkt.
} 
en een bijeenkomst waarin werd nagedacht over het werkprogramma van het RPB.

Er was slechts een aantal bijeenkomsten waar onze aanwezigheid niet gewenst was. Dit gold bijvoorbeeld voor strategische bijeenkomsten met beleidsmakers en andere vertegenwoordigers van de ministeries uit angst voor een zogenaamd "onthullendkijkje-achter-de-schermen" -verhaal over strategieën van directies, opdrachtgevers en -nemers en eventuele botsingen als gevolg van cultuurverschillen tussen de planbureaus en tussen de planbureaus en de ministeries. Omdat ons onderzoek niet gericht was op het problematiseren van organisatorische conflicten, maar op het begrijpen van wat toekomstverkenners in de praktijk doen, was het bijwonen van deze in de ogen van de toekomstverkenners strategische bijeenkomsten voor ons niet cruciaal. Onze ervaring was dat, op het moment dat we eenmaal 'binnen' waren en de toekomstverkenners gewend waren aan onze manier van werken, zich automatisch veel deuren openden. Zo werden we, ondanks eerdere reserves, ongevraagd uitgenodigd voor bijeenkomsten met vertegenwoordigers van de ministeries en konden we verschillende malen aanschuiven bij gesprekken tussen het projectteam en de planbureaudirecteur omdat dat, aldus de toekomstverkenners, "interessant" zou zijn voor onderzoek.

De informatie-uitwisseling tussen toekomstverkenners vindt niet alleen plaats in formele gremia en bijeenkomsten. Dobbinga (2001) constateert bijvoorbeeld expliciet voor de toekomstverkenningspraktijk dat informatie-uitwisseling weliswaar plaatsvindt "tijdens officiële bijeenkomsten zoals vergaderingen en overleggen", maar ook "bij informele interacties: het buurten, de koffieautomaat, in de kantine, op borrels en in het OV". Ik woonde daarom niet alleen formele, maar ook informele contactmomenten bij tussen de toekomstverkenners werkzaam in de drie geobserveerde toekomstverkenningen. Ik heb bijvoorbeeld met de toekomstverkenners geluncht, bij de koffieautomaat gezeten en ontmoetingen in de trein op weg en van Den Haag gehad. Naast deze informele contactmomenten heb ik interne emaillijsten gevolgd, stukken uit de RPBarchieven bestudeerd, processtukken geanalyseerd (zoals plannen van aanpak, notulen van vergaderingen, tussentijdse versies en andere tussenproducten), vragen gesteld, foto's en geluidsopnamen gemaakt en bestudeerd. Ook maakte ik gebruik van diepte-interviews met projectleden vaak na afloop van het project. Ik bestudeerde secundaire bronnen, zoals beschrijvingen van de geschiedenis, taak en werkwijze van RPB en andere planbureaus, onderzoek op het terrein van toekomstverkenningen en krantenartikelen over de planbureaus. Daarnaast bestudeerde ik diverse nieuwsbrieven die door het RPB werden uitgebracht en bezocht ik regelmatig de RPB-website.

Om grip te krijgen op de overvloed aan gegevens en om het empirische materiaal te kunnen ordenen schreef ik uitgebreide observatieverslagen ${ }^{25}$. We besloten om alle observaties uit de praktijk niet chronologisch te documenteren, maar gebruik te maken

\footnotetext{
${ }^{25}$ Vanwege vertrouwelijke informatie zijn deze verslagen niet gedeponeerd. Geïnteresseerden kunnen uiteraard op verzoek inzage krijgen.
}

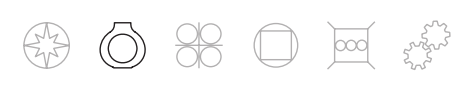


van een 'observatieprotocol', om te bewerkstelligen dat alle beschrijvingen min of meer dezelfde structuur zouden krijgen vanuit het idee dat dit de analyse van heterogene onderzoeksdata en het vergelijken van verschillende gevalsstudies zou vereenvoudigen. In dit format maakten we onderscheid tussen verschillende categorieën die kopjes meekregen als 'Dataverzameling, onze rol en wijze van observeren', 'Achtergronden en omstandigheden', 'projectorganisatie en stand van zaken' en 'methodologie', 'zelfreflectie', 'uitkomsten sessie' en 'overige opvallende citaten en observaties'. Onder het kopje 'methodologie' verzamelden wij procesdata met het doel te kunnen begrijpen voor welke uitgangspunten, procesaanpak en methoden en technieken gekozen wordt en waarom.

Het zoeken naar overeenkomsten en verschillen tussen sterk vergelijkbare gevallen is een manier om tot nieuwe inzichten te komen (Eisenhardt, 1989: 540-1). Door meerdere toekomstverkenningen te volgen binnen het RPB en uitstapjes te maken naar toekomstverkennende praktijken bij andere planbureaus, beoogde ik inzicht te krijgen in het specifieke en het algemene van mijn observaties. Om meer inzicht te krijgen in de ontwikkelingen op het gebied van toekomstverkennen buiten de planbureaupraktijk van het RPB heb ik een aantal andere toekomstverkennende projecten wat meer op afstand gevolgd, zoals de Duurzaamheidsverkenning van het Milieu- Natuurplanbureau (MNP) (RIVM, 2004) en de Referentieraming (ECN, 2005), het BETER-project en de bijdrage van het Energieonderzoek Centrum Nederland (ECN) aan WLO. Daarnaast woonde ik verschillende presentaties van toekomstverkennende studies bij, zoals het project 'QUESTA' van het Ministerie van Verkeer en Waterstaat (Dobbinga, 2001), de CPB-studie Four Futures of Europe (CPB, 2003) (Maastricht, 12 november 2004), het SCP-project 'In het zicht van de toekomst' (SCP, 2004) en het WRR-rapport WRR, vijfentwintig jaar later (van der Duin, Hazeu, Rademaker, \& Schooneboom, 2004) (Den Haag, 17 september 2004). Ook was ik zijdelings betrokken bij een project in opdracht van het Ministerie van Binnenlandse Zaken en Koninkrijksrelaties, waarin een inventarisatie is gemaakt van toekomstverkenningen die na 1997 zijn verschenen in Nederland (van Asselt, de Wilde, van der Pas, Wolthuis, et al., 2005). Ook het promotieonderzoek van van Notten (2005) dat in het kader van het onderzoeksprogramma 'Perspectives on Uncertainty and Risk: An interdisciplinary methodology program on Toekomstverkenning' (van Asselt, 2003) is geschreven verschafte mij een bredere blik op toekomstverkenningen. 


\subsection{Mijn methodologische bril}

Hoewel het in retrospectief, mede gevoed door mijn gestileerde presentatie, misschien lijkt alsof de praktijk van toekomstverkennen zich aan mij ontvouwde, heb ik mijn bevindingen betekenisvol moeten maken door ze te beschouwen door verschillende interpretatieve lenzen.

Ik begon mijn empirisch onderzoek zonder een vooraf bedachte theoretische opzet of kant-en-klaar, vastomlijnd interpretatiekader voor de verzameling en analyse van mijn onderzoeksdata. In plaats van te kiezen voor een min of meer uitgewerkte theoretisch plan koos ik voor een meer exploratieve aanpak, waarin ik begon met een zeer brede onderzoeksvraag, namelijk - hoe produceren toekomstverkenners kennis over de toekomst? - en een aantal algemene categorieën zoals die mij hielpen een eerste ordening te maken van de heterogene onderzoeksdata. Werkenderweg werden mijn onderzoeksvragen specifieker en versmolten de algemene categorieën waarmee ik dit onderzoek was begonnen tot thema's waarbinnen ik de verschillende gedocumenteerde fragmenten uit verschillende toekomstverkenningen in samenhang kon bespreken en analyseren. In mijn geval kwamen deze onderzoeksvragen en thema's voort uit verwondering over ogenschijnlijke tegenstrijdigheden tussen de ambities die toekomstverkenners zichzelf voorafgaand aan en tijdens de toekomstverkenningsexercitie stelden, en het handelen van de toekomstverkenners in de dagelijkse praktijk.

In mijn onderzoek ben ik mij dus gaan richten op het vergelijken en contrasteren van de gestelde ambities en de praktijk. Zoals ik heb beschreven in hoofdstuk 1 maak ik in mijn onderzoek een onderscheid tussen twee centrale verkenningsambities die verbonden zijn met de nieuwe toekomstoriëntatie. Het bewustzijn van fundamentele onzekerheden waarmee het verkennen van de toekomst is omgeven, manifesteerde zich in de praktijk van toekomstverkennen in de ambitie om de variëteit aan toekomstbeelden die denkbaar is door de toekomst vanuit verschillende perspectieven te beschouwen, te vertalen naar de set van scenario's. Naar deze ambitie verwijs ik met de term 'de variatieambitie'. Het besef dat de hedendaagse samenleving complexer is dan ooit tevoren en dat ontwikkelingen dus niet geïsoleerd kunnen worden beschouwd, vond ik in de praktijk terug in de ambitie van toekomstverkenners verschillende thema's, disciplines en perspectieven te willen integreren. Het integreren is gericht op het krijgen van nieuwe thema- en disciplineoverstijgende inzichten. Dit noem ik de 'integratieambitie'.

Deze ambities lijken verschillende dimensies te hebben ${ }^{26}$. Allereerst reflecteren zij een

\footnotetext{
${ }^{26}$ Van Lente (1993) maakt een onderscheid tussen drie dimensies ten aanzien van 'expectations', namelijk "cognition", "action-guiding" and "legitimation". Deze drie dimensies lijken ook van toepassing op de integratie- en variatieambitie.
}

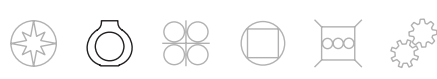


bepaalde opvatting ten aanzien van de kenbaarheid van de toekomst. Daarbij lijkt van deze centrale verkenningsambities een sterk structurerende en sturende werking uit te gaan, omdat het vocabulaire dat met deze ambities gepaard gaat, kan fungeren als rechtvaardiging voor het handelen, zowel in de communicatie naar 'de buitenwereld' als tussen de toekomstverkenners in projecten. Ambities kunnen, doordat ze een gedeeld kader vormen waarbinnen argumentatie kan plaatsvinden, richting geven aan wat wel en niet zou moeten worden gedaan om te komen tot een verkenning van de toekomst. Oog voor deze verschillende dimensies kan helpen te begrijpen en te verduidelijken waarom toekomstverkenners doen wat zij doen, hoe ze dat doen en hoe hun werkwijze 'ontstaat'.

In dit proefschrift wil ik beschrijven en analyseren hoe toekomstverkenners deze centrale verkenningsambities in de praktijk (proberen te) realiseren en welke rol de ambities spelen in het produceren van toekomstkennis. Om inzicht te krijgen in de manieren waarop toekomstverkenners deze ambities vertalen in de praktijk ben ik door middel van etnografisch onderzoek op zoek gegaan naar methodieken en verkenningsbenaderingen die toekomstverkenners bewust of onbewust, impliciet of expliciet, inzetten om hun ambities te realiseren. Het kijken naar manieren waarop toekomstverkenners ambities trachten te realiseren als lens bij het analyseren van het empirische materiaal over SCENE, WVR en WLO lijkt een aantal aanknopingspunten te kunnen bieden om te kunnen begrijpen waarom toekomstverkenners doen wat zij doen en waarom toekomstverkenningen soms anders verlopen dan verwacht of beoogt bij aanvang van de toekomstverkenning.

In de volgende twee hoofdstukken zal ik in detail beschrijven hoe toekomstverkenners de variatieambitie (hoofdstuk 3) en de integratieambitie (hoofdstuk 4) (proberen te) realiseren. 
S6

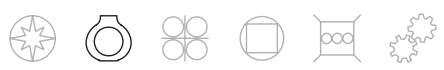





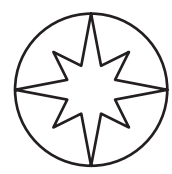

(0)
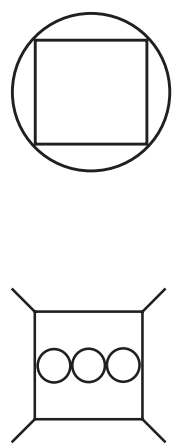

5 


\title{
(3) De variatieambitie: werken met een assenstelsel $^{27}$
}

\begin{abstract}
Veel hedendaagse toekomstverkenners gebruiken de onzekerheid waarmee de toekomst is omgeven als hét startpunt en legitimatie van hun toekomstverkenningen. En dit geldt ook voor de toekomstverkenners in de SCENE-toekomstverkenning. Het ontwikkelen van scenario's was in hun ogen een manier om rekening te kunnen houden met andere omstandigheden, nieuwe ontwikkelingen, onbekende mechanismen en ongewone samenlopen van omstandigheden. Het uitgangspunt was dat de toekomst niet voorspeld kan worden en dat het daarom verstandig was om met verschillende toekomstbeelden rekeningen te houden.
\end{abstract}

Deze toekomstverkenners gebruiken "onzekerheid" en het "niet weten" dus als een legitimatie om verschillende "alternatieve" perspectieven op hoe de toekomst zich zou kunnen ontvouwen te verkennen. Zij stellen zichzelf daarom tot doel verschillende consistente verhalen te vertellen over hoe trends kunnen uitpakken en hoe onzekerheden geïnterpreteerd kunnen worden. Hoe geven de toekomstverkenners in de praktijk invulling aan deze variatieambitie? Hoe proberen de verkenners 'variatie' te bewerkstelligen? Of met andere woorden, hoe 'doen' toekomstverkenners 'variatie'?

De SCENE-toekomstverkenners kozen ervoor te werken met een assenstelsel als manier om variatie tussen de scenario's te krijgen. In dit hoofdstuk zal ik in detail beschrijven hoe de verkenners in dit project met het assenstelsel als variatie-instrument hebben gewerkt en hoe zij deze methodiek hebben toegepast voor het realiseren van de variatieambitie. In dit hoofdstuk zal ik beschrijven hoe toekomstverkenners werkten met het assenstelsel als instrument voor het realiseren van de variatieambitie ${ }^{28}$.

\subsection{Het assenstelsel als variatie-instrument}

In de literatuur over toekomstverkenningen wordt het assenstelsel vaak aangeprezen als hulpmiddel om verschillende, uiteenlopende beelden over de toekomst te construeren en structureren ${ }^{29}$. Het assenstelsel wordt vaak neergezet als een standaardtechniek die toekomstverkenners in staat stelt variatie tussen de scenario's te bewerkstelligen.

\footnotetext{
${ }^{27}$ Een eerdere versie van dit hoofdstuk is verschenen in het tijdschrift Futures (van 't Klooster \& van Asselt, 2006).

${ }^{28}$ Deze scenariomethodiek werd door de toekomstverkenners in het SCENE-project niet ontleend aan de handboeken, maar deze werd gesuggereerd door een externe adviseur. De praktiserende toekomstverkenners maakten bij het verkennen van de toekomst geen gebruik van dergelijke handboeken.

${ }^{29}$ Er zijn ook andere manieren denkbaar om verschillend, uiteenlopende beelden over de toekomst te construeren, bijvoorbeeld door verschillende vooraf gedefinieerde perspectieven als uitgangspunt te nemen. Zie ook Brooks (2004) waarin verschillende "tools for multiplicity" worden beschreven.
} 
Zo verwijst Ringland (2002) bijvoorbeeld naar het assenstelsel als "the standard tool used to sort out ideas and factors" (174) en het Ministerie van Binnenlandse Zaken omschrijft deze aanpak als "een van de meest gehanteerde technieken om te komen tot scenario's" (BZK, 2003: 32). Het gebruik van het assenstelsel wordt ook beschreven in het boek Scenario's: The Art of Strategic Conversation van van der Heijden (1996) wat door veel toekomstverkenners wordt beschouwd als een standaardwerk op het gebied van methodologie van toekomstverkennen. In beleidsgerichte toekomstverkenningen werd het assenstelsel al in veel verschillende contexten gebruikt: bijvoorbeeld in de ruimtelijke ordening, zoals Nederland 2030 (RPD, 1997); in klimaatonderzoek (IPCC, 1990); (IPCC, 2000) in economische studies, zoals Scanning the Future (CPB, 1992) en Four Futures of Europe (CPB, 2003); energieonderzoek (ECN, 1998) en (Essent, 2003) en het milieuonderzoek (RIVM, 2000).

Het gebruik van een assenstelsel als structuur en vertrekpunt voor de constructie van uiteenlopende scenario's werd voor het eerst gepropageerd door Shell (Schwartz, 1991); (van der Heijden, 1996) (er wordt dan ook wel naar het assenstelsel verwezen als de Shell-benadering). Deze scenariomethode is grofweg opgebouwd uit vier stappen ${ }^{30}$. De eerste stap is het identificeren van potentiële drijvende krachten, namelijk ontwikkelingen die én heel onzeker zijn (en zich dus in heel verschillende richtingen kunnen ontwikkelen) én een bepalende impact zouden kunnen hebben voor de regio, het onderwerp, de thematiek, het bedrijf etc. waar het in de scenariostudie om draait. Het gaat er dus om dominante en de relatief onzekere ontwikkelingen, die toekomstverkenners vaak aanduiden met de term 'drijvende kracht' te scheiden van ontwikkelingen die minder belangrijk en onzeker zijn. In de Nationale Milieuverkenning 5 las ik bijvoorbeeld hoe de toekomstverkenners bij het RIVM "demografische ontwikkeling" aanmerkten als "een relatief zekere en dominante factor" en de aard en snelheid van technologische ontwikkelingen in niet-geïndustrialiseerde wereldregio's als "betrekkelijk onzeker" (RIVM, 2000: 40). Van der Heijden (1996) definieert een drijvende kracht als "a "place holder" for an environmental force, driving a possible outcome of a critical uncertainty" (228). Het identificeren van potentiële drijvende krachten is volgens (Schwartz, 1991) de meest onderzoeksintensieve stap in het scenarioproces. Vervolgens gaat het erom de twee meest belangrijke drijvende krachten, dus de ontwikkelingen, die op zowel de dimensie onzekerheid als impact hoog scoren, te selecteren ${ }^{31}$ (zie figuur 3.1).

\footnotetext{
${ }^{30}$ Verschillende auteurs onderscheiden verschillende stappen, maar in essentie komen ze op hetzelfde neer. Zo identificeert Schwartz (1991) de volgende stappen in het scenarioproces: (1) "Identify focal issue or decision"; (2) identify key forces in the local environment; (3) identify driving forces; (4) rank by importance and uncertainty; (5) selecting scenario logics; (6) fleshing out the scenarios; (7) implications, and (8) selection of leading indicators and signposts (241-6).

${ }^{31}$ In de engere betekenis van de term "driving force", namelijk als drijvende kracht achter de ontwikkeling van een systeem, lijkt de term sterker te verwijzen naar de ontwikkeling met de grootste impact dan naar onzekerheid. Echter, omdat het in toekomstverkennen meestal gaat om complexe
}

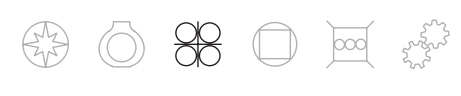




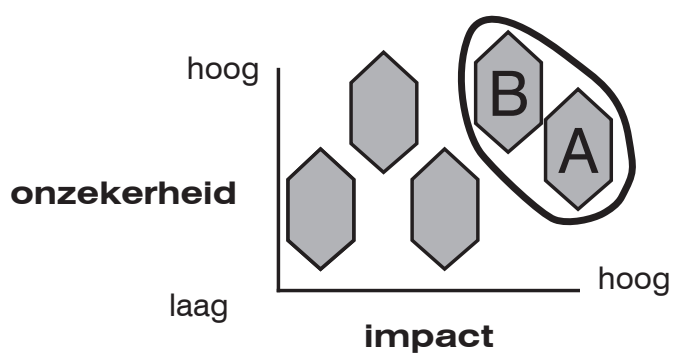

Fig. 3.1 - selecteren van twee drijvende krachten

De twee belangrijkste en onzekere drijvende krachten (A en B) worden dan elk op een as gezet en van twee uitersten voorzien. Op deze manier ontstaan er vier scenariokwadranten:

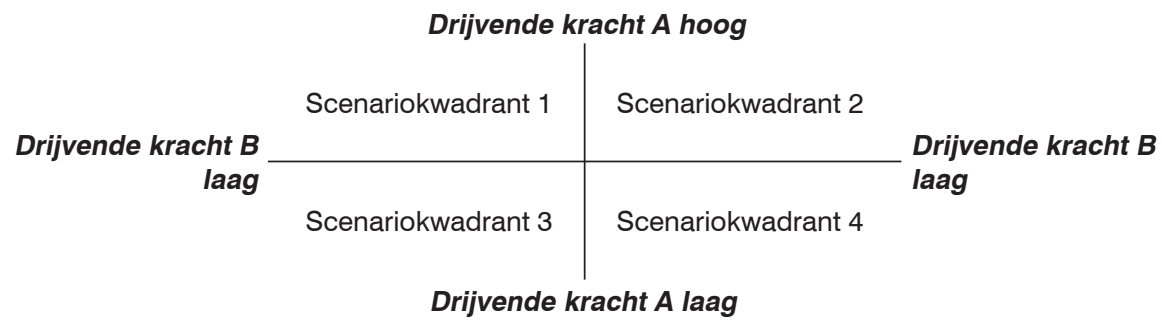

Fig. 3.2 - Assenstelsel met vier kwadranten

De volgende stap is dan het "inkleuren" van de kwadranten. Volgens de scenario literatuur ontstaan door het identificeren van de twee meest belangrijke drijvende krachten vier zogenaamde "hoekpunten" voor de denkbare ontwikkelingen, waaraan fundamenteel verschillende aannames (of, met andere woorden, interpretaties van de belangrijkste onzekerheden) ten grondslag liggen. Het assenstelsel biedt op deze manier een raamwerk voor toekomstverkenners voor het op een consistente manier doordenken van uiteenlopende perspectieven op mogelijke toekomstige ontwikkelingen. Het assenstelsel zou, vanuit mijn perspectief, dus kunnen worden opgevat als een manier om verschillende perspectieven op de toekomst te structureren en daarmee de variatieambitie te realiseren.

Het gebruik van het assenstelsel wordt zowel in de literatuur over methoden van 
scenario-ontwikkeling als in de scenariorapporten zelf vaak onproblematisch verondersteld. Het wordt dan gezien als een eenduidige methode waarmee op eenvoudige wijze vier scenario's ontwikkeld kunnen worden. In het boek Scenarios. The Art of Strategic Conversation van van der Heijden (1996) wordt dit onproblematische karakter echter enigszins genuanceerd als hij stelt dat "this approach is only practical if two (..) overwhelming driving forces can be identified". In de praktijk van toekomstverkennen is het echter niet de vraag of er twee bepalende drijvende krachten zijn, maar wordt aangenomen dat er twee drijvende krachten zijn die het systeem bepalen (zie bijv. Ringland (2002); BZK (2003) en Berkhout \& Hertin (2002)). Het uitgangspunt is, met andere woorden, dat drijvende krachten kunnen worden gevonden 'out there' en dat goede toekomstverkenners deze uiteindelijk ook zullen vinden. Zo stelt Schwartz bijvoorbeeld dat "the process of building scenarios starts with (..) looking for driving forces" (Schwartz, 1991: 101). En van der Heijden (1996) adviseert toekomstverkenners die nog geen goed inzicht hebben in de belangrijkste onzekerheden waarmee het systeem is omgeven "to spend more time discussing the findings and underlying structure to try to develop a better insight in the crucial driving forces in the future" (196). De boodschap is, met andere woorden, dat vakkundig zoeken en verzamelen van informatie de toekomstverkenners uiteindelijk tot dé twee drijvende krachten zal brengen. En de suggestie is dat, als deze uiteindelijk zijn gevonden, het assenstelsel niet zomaar een structuur is voor het maken van scenario's, maar de enige zinvolle structuur. In de scenariohandboeken wordt het assenstelsel neergezet als een soort 'skelet'. Ik gebruik de skeletmetafoor om de manier waarop het assenstelsel wordt neergezet in scenariohandboeken te duiden. In deze handboeken krijgt het assenstelsel namelijk een specifieke functionele betekenis toegewezen, namelijk als structuur dat "determine the stories outcome" (Schwartz, 1991: 101-2): zoals een skelet vorm geeft aan lichamen en gebouwen, zo bepaalt het assenstelsel de verhalen die kunnen worden verteld over de toekomst. In de skeletbenadering wordt variatie beschouwd als een eigenschap van het onder beschouwing zijnde systeem. Variatie wordt daarmee bepaald door de twee belangrijkste en meest onzekere ontwikkelingen die het verloop van het systeem sturen. Volgens deze variatiebenadering kan variatie worden 'gevonden' of 'ontdekt' door middel van gedegen, systematische analyse en een goed begrip van de werking van het systeem.

Omdat de assenbenadering wordt gezien als standaardmethode, wordt de keuze voor de twee assen en de uitwerking daarvan nauwelijks onderbouwd. In de presentatie van de gehanteerde werkwijze wordt dan, als het gaat over het werken met het assenstelsel, vaak volstaan met opmerkingen als "This is how we did it" (Maastricht, 12 februari 2004: presentatie CPB-rapport Four Futures of Europe), waarbij wordt verondersteld dat slechts het noemen van het assenstelsel voldoende uitleg geeft over de gevolgde werkwijze. Vergelijkbare 'ex post'-verhalen over het gebruik van het assenstelsel kunnen worden gevonden in gerefereerde tijdschriften op het gebied van toekomstverkennen. Smith et al., (2005) stellen bijvoorbeeld dat het assenstelsel "shows the two axes and the

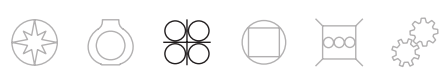


four scenarios which arise from them" en spreekt over " (..) the four different scenarios generated by these two axes" (9). Een toekomstverkenner bij het Amerikaanse "Institute for the Future' verwees naar het assenstelsel als "the easy way to start building a scenario" en legt uit:

"Just make a four square, start with something low in the lower corner, something high in the upper and out corners. See if they fall into four different kinds of stories" (Geciteerd in Brooks (2004: 143)).

In de scenarioliteratuur wordt het assenstelsel voorgesteld als een 'skelet' voor het maken van scenario's. Hoe 'werkt' deze skeletbenadering van het assenstelsel, waarnaar in de literatuur vaak wordt verwezen als een "standaard", in de praktijk?

\subsection{Het assenstelsel als 'skelet' in de SCENE-praktijk}

De eerste verwijzingen naar het assenstelsel in SCENE vond ik terug nog voor de officiële start van het scenarioproject. De projectleider in spé ontving in deze periode een offerte van een externe onderzoeker (een expert in scenariomethodologie aan de Katholieke Universiteit Nijmegen (KUN)) voor het organiseren van twee werkconferenties. In deze offerte stelde deze onderzoeker voor de deelnemers aan de werkconferentie door middel van scenariobouw na te laten denken "over verschillende mogelijke ontwikkelingen". Hier refereert hij dus expliciet aan de variatieambitie. Het idee om een assenstelsel te hanteren werd in deze offerte geïntroduceerd door te stellen:

"Scenariobouw plaatst de meest belangrijke en meest onzekere omgevingsontwikkelingen (welke hij vervolgens aanduidt met de engelse term 'driving forces', sk) in een assenkruis haaks op elkaar" (KUN offerte, 28 september 2001: 3).

In de offerte redeneerde hij verder dat op basis van een assenkruis vier kwadranten ontstaan "die elk een mogelijke en waarschijnlijke toekomst presenteren" (KUN offerte, 28 september 2001: 3) en dat "van elk kwadrant vervolgens een scenario" (wordt, sk) gemaakt". Hij gaf daarbij het volgende voorbeeld: 


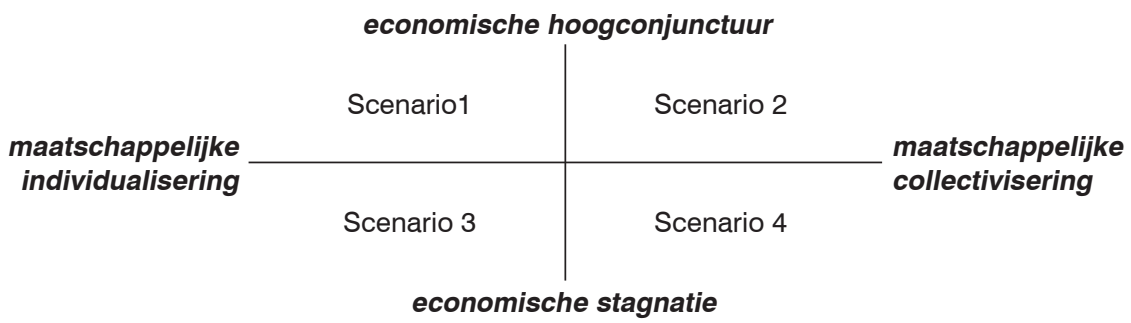

Fig. 3.3 - Het SCENE assenstelsel als 'skelet' (KUN, 28 september 2001: 3)

Ook op de werkvloer verwezen de toekomstverkenners in deze beginperiode veelvuldig naar de variatieambitie. Zo zeiden zij het assenstelsel te beschouwen als een manier om scenario's te ontwikkelen die "duidelijk verschillende richtingen opwijzen". Sommige toekomstverkenners verwezen naar het assenstelsel als "skelet" voor de scenario's ${ }^{32}$. De manier waarop de toekomstverkenners tijdens de toekomstverkenning spraken en schreven over het assenstelsel (met verwijzingen als "de meest belangrijke en meest onzekere ontwikkelingen" en "trends met veel impact en hoge onzekerheid") kwam in de beginfase dus overeen met het vocabulaire zoals dat wordt gebruikt in de scenariohandboeken. Voor de toekomstverkenners in SCENE leek het gebruik van een assenkruis de vanzelfsprekende / logische manier voor het ontwikkelen van scenario's. Zij zeiden door op deze manier scenario's te ontwikkelen de "bandbreedte" van wat mogelijk is in de toekomst te kunnen verkennen (Werkconferentie SCENE, 16 januari 2002).

De eerste stap die de toekomstverkenners namen om te komen tot een eerste inventarisatie van potentiële drijvende krachten was het transformeren van de algemene definitie van drijvende krachten naar een definitie in termen van de RPB-context. De toekomstverkenners maakten de volgende vertaling van drijvende krachten, namelijk als "de maatschappelijke ontwikkelingen die sterke ruimtelijke effecten hebben". Op deze manier werd het eerste criterium 'impact' nader gespecificeerd. Ook 'onzekerheid' kreeg een meer specifieke invulling door drijvende krachten te definiëren als datgene "waar zich onzekerheden of dilemma's voordoen of waarover praktijkmensen of vakgenoten discussie voeren" en als datgene "waarop beleidsmakers die betrokken zijn bij de ruimtelijke ordening (nagenoeg) geen invloed op uitoefenen" of als "ontwikkelingen en trends waarop beleidsmakers en belanghebbenden nagenoeg geen invloed hebben, maar die de ruimtelijke inrichting en de ruimtelijke ordening wel sterk beïnvloeden" (Eerste en tweede vragenlijst, 21 november 2001). Uit deze definities blijkt dat de

${ }^{32}$ De aanduiding van het assenstelsel als 'skelet' is dus zowel een onderzoekersterm als een term die de actoren gebruiken.

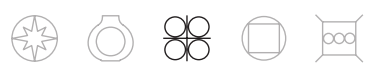


toekomstverkenners onzekerheid niet alleen beschouwen als een eigenschap van een drijvende kracht, maar tevens een kenmerk van een sociaal discours dat afgeleid kan worden uit een controverse. De "standaard"-definitie van drijvende krachten "volgens het boekje" werd dus getransformeerd en gecontextualiseerd, waarmee het een aantal nieuwe, specifiekere criteria meekreeg. De toekomstverkenners gebruikten deze RPBspecieke definitie van drijvende krachten als maatstaf voor het selecteren van relevante trends.

$\mathrm{Na}$ het identificeren van potentiële drijvende krachten begon de skeletbenadering van het assenstelsel enkele scheurtjes te vertonen. Het onderzoek bleek namelijk geen drijvende krachten op te leveren die "er uit sprongen", maar een lijst van "tien plausibele drijvende krachten":

\section{Trend}

1. Conjuncturele ontwikkeling

2. Klimaatveranderingen

3. Internationale migratie

4. Invloed van de economie op de samenleving

5. Impact van rampen op de samenleving

6. Milieubewustzijn in de samenleving

7. Technologische ontwikkelingen

8. Concurrentiepositie van Nederland

9. Mate van globalisering

10. Internationale politieke situatie

$\begin{array}{lll}\text { Impact } & \text { Onzekerheid } & \text { Som } \\ 1 & 3 & 4 \\ 3 & 9 & 12 \\ 8 & 7 & 15 \\ 3 & 14 & 17 \\ 15 & 2 & 17 \\ 11 & 8 & 19 \\ 9 & 11 & 20 \\ 20 & 5 & 25 \\ 14 & 12 & 26 \\ 25 & 1 & 26\end{array}$

Tabel 3.1 - lijst van "tien meest plausibele drijvende krachten" (gedestilleerd uit de derde Delphi vragenlijst, 7 december 2001). In deze lijst zijn de trends geordend op basis van de som van de score op impact en de score op de mate van onzekerheid. Hoe lager de score, hoe groter door de respondenten de impact en mate van onzekerheid veronderstelden.

Als de toekomstverkenners de Delphi-uitkomst conform de formele skeletbenadering zouden interpreteren, dan zouden zij op basis van de scores conjuncturele ontwikkeling en klimaatverandering kunnen aanmerken als de belangrijkste drijvende krachten omdat zij het laagst scoren op de som van impact en onzekerheid. Als ze uit zouden gaan van de laagste individuele score dan scoort conjuncturele ontwikkeling het hoogst op impact en de internationale politieke situatie op onzekerheid. Deze laatste scoort echter weer relatief hoog op impact. De toekomstverkenners stelden dat "uit de bovenstaande prioritering blijkt dat de conjuncturele ontwikkeling veruit het hoogst scoort op impact en onzekerheid". Dit was reden om in ieder geval conjuncturele ontwikkeling als één van de drijvende krachten aan te merken. De toekomstverkenners constateerden echter dat de keuze voor de tweede drijvende kracht niet zo vanzelfsprekend was omdat de scores van verschillende trends volgens de toekomstverkenners "redelijk dicht bij elkaar liggen". De 
toekomstverkenners doelden hier op de scores van "klimaatveranderingen, internationale migratie, invloed van economie op de samenleving, en impact van rampen op de samenleving". Er zijn dus vier trends die volgens de toekomstverkenners in aanmerking zouden kunnen komen voor "drijvende kracht". Om toch te komen tot de belangrijkste drijvende krachten waarmee het theoretische skeletideaal in stand gehouden kon worden, moesten de toekomstverkenners, zoals ik hieronder in detail zal beschrijven, veel argumentatief werk verzetten. Daarbij gebruikten zij afwisselend methodologische en inhoudelijke argumenten.

Allereerst stelden de toekomstverkenners dat "de ervaring leert dat meer dan twee trends onhandelbaar is, omdat het leidt tot erg veel scenario's (een combinatie van twee trends leidt tot vier scenario's; een combinatie van drie trends leidt al tot acht scenario's)" (Derde vragenlijst, 7 december 2001). Dominant voor de keuze voor de twee trends was dus het denken in termen van twee assen en vier kwadranten en de wens om maar tot vier scenario's te komen ${ }^{33}$.

Vervolgens zetten zij allerlei inhoudelijke argumenten in om "minder geschikte" drijvende krachten af te kunnen strepen van het lijstje. Zo lieten zij internationale migratie afvallen omdat deze trend geen duidelijke relatie zou hebben met de Vijfde Nota en impact van rampen op de samenleving, omdat volgens de toekomstverkenners niet duidelijk was hoe deze trend kan "werken als driving force voor de ruimtelijke ordening". Deze trend zeiden zij te beschouwen als een secundaire ontwikkeling, omdat deze zou worden aangestuurd door andere structurele ontwikkelingen als klimaatverandering en de internationale politieke situatie ${ }^{34}$. Over klimaatverandering stelden de toekomstverkenners dat het de vraag is "in hoeverre deze trend alle vier de thema's van de Vijfde Nota afdekt" en dat de relatie tussen klimaatverandering en de thema's van de Vijfde Nota niet duidelijk was. De toekomstverkenners gebruikten dus niet de criteria die vooraf waren bepaald, namelijk hoge score op impact en onzekerheid, maar andere, inhoudelijke argumenten die deels voortvloeiden uit de getransformeerde, gecontextualseerde criteria.

\footnotetext{
${ }^{33}$ Toekomstverkenners zeggen vaak te kiezen om een viertal scenario's te ontwikkelen om te voorkomen dat de gebruikers van de scenario's worden verleid, in het geval van twee scenario's, een middenvariant te kiezen tussen twee extremen, of, in het geval van drie scenario's, voor het zogenaamde "middenscenario". Dammers (2000) beschrijft bijvoorbeeld dat in de discussies over de toekomst van Schiphol de stuurgroep Project Mainport en Milieu Schiphol besloot de uitbreidingsstrategie te baseren op slechts een van de CPB scenario's over de economische groei en de ontwikkelingen in de luchtvaartsector, namelijk het scenario dat het meest aansloot bij de gekozen mainport- en milieudoelstellingen (zie bijvoorbeeld Dammers (2000: 273)).

${ }^{34}$ Deze argumentatie zou kunnen worden opgevat als een uiting van discontinuïteitintolerantie (zie van Notten (2005)), omdat mogelijke toekomstige discontinuïteiten uit de scenarioanalyse worden weggeredeneerd.
}

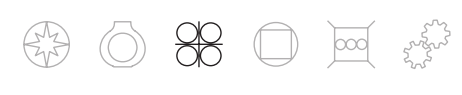


Daarnaast gebruikten zij ook de inschatting van de mate van verandering in een bepaalde tijdsperiode als selectiecriterium. Zo stelden zij bijvoorbeeld dat het de vraag was of de klimaatveranderingen de komende twintig jaar dermate groot zijn dat het interessant is om de scenario's daar op in de delen".

Van de negen overgebleven trends bleven er na het doorstrepen van internationale migratie, de impact van rampen op de samenleving en klimaatverandering dus nog zes over. Om de keuze uit zes potentiële drijvende krachten verder terug te brengen introduceerden de toekomstverkenners nog een nieuw selectiecriterium in, namelijk het afhankelijk zijn van een drijvende kracht met de al gekozen drijvende kracht. De toekomstverkenners stelden namelijk dat de respondenten de trend 'invloed van de economie op de samenleving' niet als erg onzeker hadden aangemerkt en dat de trend, aldus de toekomstverkenners, sterk samenhangt met de economische ontwikkeling. Op basis hiervan achtten zij deze trend "niet bij uitstek geschikt als driving force". We zien hier dus dat de toekomstverkenners impliciet een nieuw selectiecriterium introduceerden, namelijk het afhankelijk zijn met de al gekozen drijvende kracht.

Na deze afvalrace beargumenteerden de toekomstverkenners welke van de vijf overgebleven trends het meest geschikt waren. Om dat te kunnen doen introduceerden zij nogmaals expliciet een selectiecriterium dat al eerder impliciet in de argumentatie was gebruikt, namelijk "de mate waarin trends van elkaar verschillen". Zij stelden dat "vanuit dat perspectief bezien, (..) conjuncturele ontwikkeling, klimaatverandering en milieubewustzijn in de samenleving in duidelijk verschillende bereiken (lijken, sk) te liggen". De toekomstverkenners zetten klimaatverandering, dat zij eerder diskwalificeerde als drijvende kracht, dus weer op het lijstje. De suggestie is dat de andere overgebleven trends (technologische ontwikkeling, concurrentiepositie van Nederland, mate van globalisering en internationale politieke situatie) niet aan dit criterium zouden voldoen, wat reden is om ze van het lijstje weg te strepen.

Dit argumentatieve werk stelde de toekomstverkenners in staat de lijst van 10 "plausibele drijvende krachten" te reduceren tot drie, namelijk economische groei, milieubewustzijn en klimaatverandering. Deze drie potentiële drijvende krachten gebruikten de toekomstverkenners vervolgens om twee verschillende assenstelsels te construeren: de eerste met de assen economische ontwikkeling en klimaatverandering en de tweede met de assen economische ontwikkeling en milieubewustzijn (zie figuur 3.4). In deze stap van drie potentiële drijvende krachten naar twee assen 'verdwijnt' de combinatie milieubewustzijn en klimaatverandering onopgemerkt uit beeld. Op deze manier konden de toekomstverkenners het aantal mogelijke assenstelsel verder reduceren.

Om het idee van een assenstelsel zoals dat wordt beschreven in de handboeken overeind te houden moesten de toekomstverkenners veel argumentatief werk verzetten. Er was dus geen sprake van dé belangrijkste twee drijvende krachten die vanzelf 
oprijzen, maar er waren meerdere assen mogelijk en denkbaar, waardoor er keuzes gemaakt moesten worden. Selectiecriteria werden impliciet en expliciet toegevoegd, benadrukt, gecontextualiseerd en gespecificeerd of juist naar de achtergrond geplaatst. De potentiële drijvende krachten werden gescoord en beoordeeld in het licht van deze complexe verzameling van selectiecriteria. Ook werden zij geherdefinieerd en geclusterd. Op deze manier slaagden de toekomstverkenners erin om de lijst van meerdere potentiële of "plausibele" drijvende krachten terug te brengen tot twee kandidaatassenstelsels.

Assenstelsel 1:

\begin{tabular}{|c|c|c|c|}
\hline \multicolumn{4}{|c|}{ economische hoogconjunctuur } \\
\hline weinig & Scenario1 & Scenario 2 & \multirow{3}{*}{$\begin{array}{l}\text { veel } \\
\text { klimaatveranderingen }\end{array}$} \\
\hline klimaatveranderingen & & & \\
\hline & Scenario 4 & Scenario 3 & \\
\hline
\end{tabular}

Assenstelsel 2:

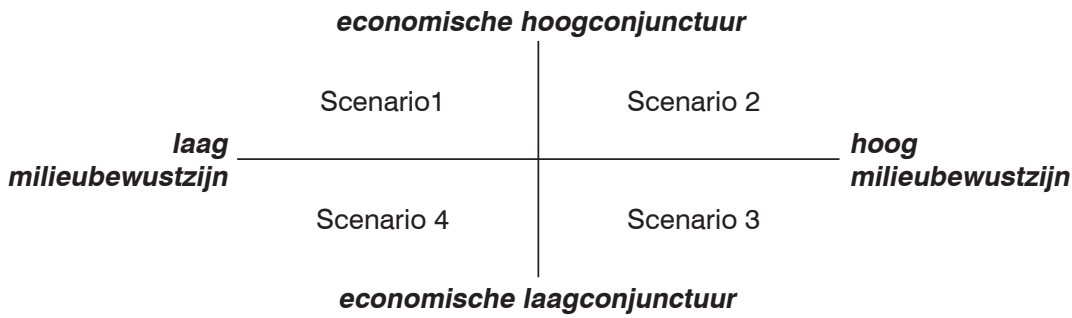

Fig. 3.4 - Twee potentiële assenstelsels

Hoewel de toekomstverkenners veel meer hadden gedaan dan alleen de drijvende krachten te kiezen die het hoogst scoorden op onzekerheid en impact bleven zij gedurende de hele scenario-exercitie verwijzen naar het assenstelsel als skelet. Ook in de manier waarop deze toekomstverkenners het assenstelsel visualiseerden reflecteerde de skeletbenadering (zie de figuren 3.5a en 3.5b op de volgende pagina). 


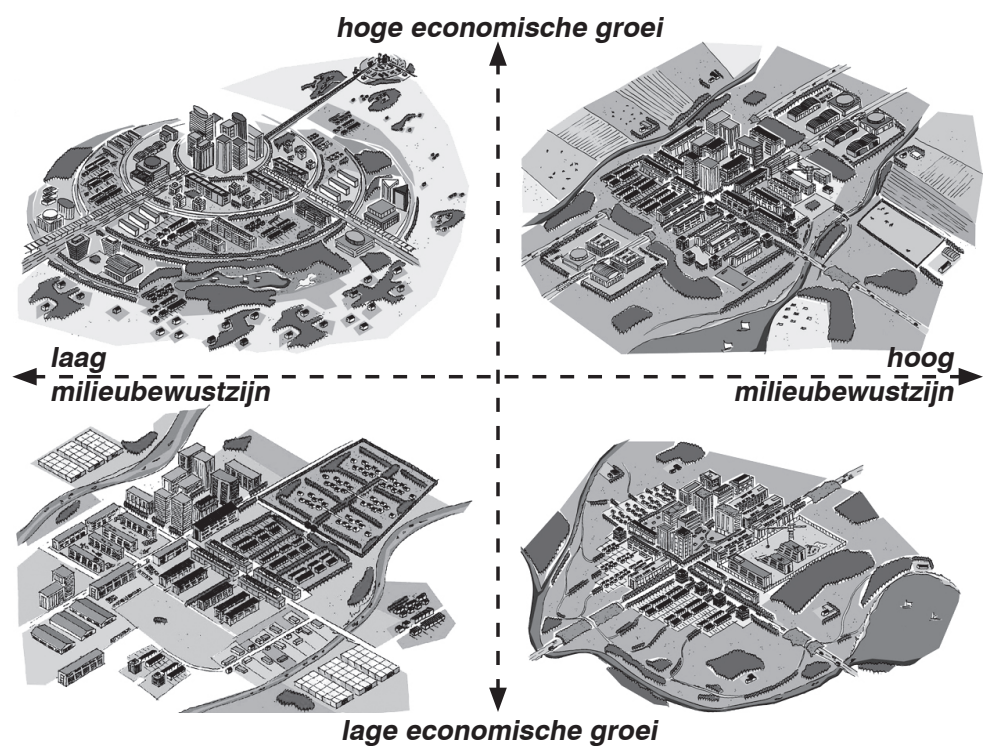

Fig. 3.5a - Het assenstelsel als skelet

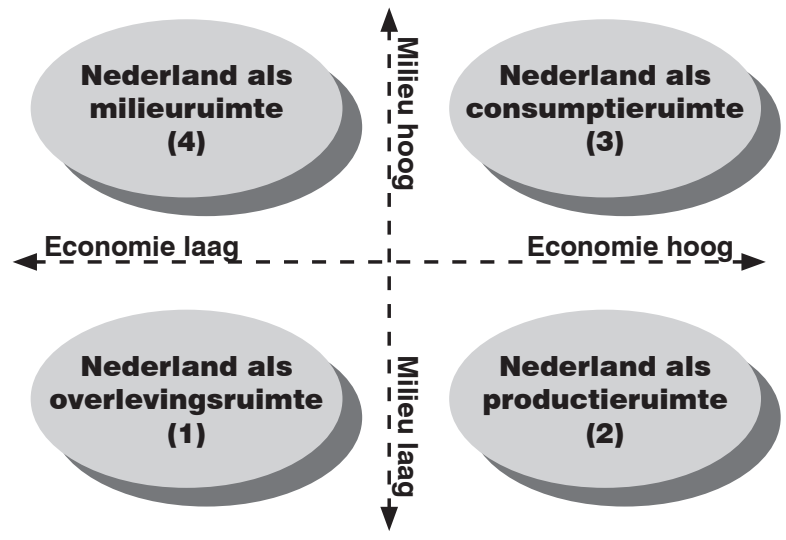

Fig. 3.5b-Het assenstelsel als skelet 
Beide figuren zijn ideaaltypische skeletrepresentaties: twee assen als skelet voor vier toekomsten. In 3.5a zijn de scenariokwadranten letterlijk ingekleurd door middel van vier verschillende scenariobeelden en $3.5 \mathrm{~b}$ is van tekst voorzien.

Dus, hoewel de skeletbenadering van het assenstelsel in de praktijk verschillende scheurtjes begon te vertonen wisten de toekomstverkenners, ondanks de onderliggende spanningen en tegenstrijdigheden, de skeletbenadering in stand te houden. Uiteindelijk beschreven de toekomstverkenners in twee van de vier achtergrondrapporten het assenstelsel conform het assenstelsel als skelet. In één van deze rapporten lees ik bijvoorbeeld hoe "de belangrijkste en meest onzekere driving forces" waren bepaald en dat deze in een assenkruis haaks op elkaar zijn gezet zodat er vier scenariokwadranten ontstaan en dat "gebaseerd hierop (...) een viertal scenario's gemaakt" zijn (RPB, 2002a: 6). In het concluderende hoofdstuk werd vervolgens herhaald dat "de scenario's onderscheiden zich op de onderliggende drijvende krachten: economische groei en milieubewustzijn".

\section{Het assenstelsel als 'fundering'35}

Tijdens het identificeren en selecteren van de drijvende krachten was de spanning tussen het skeletideaal en de dagelijkse praktijk voor de toekomstverkenners niet zichtbaar of problematisch. Echter, vanaf het moment dat zij begonnen met het inkleuren van de vier kwadranten begonnen verschillende toekomstverkenners ${ }^{36}$ het assenstelsel zoals dat tot dan toe was gebruikt (als skelet) te bekritiseren. Er was vooral kritiek op de selectie van de twee assen. lemand merkte op dat de keuze voor de assen economische groei en milieubewustzijn een nogal klassiek schema opleverde en stelde voor toch nog op zoek te gaan naar andere, meer vernieuwende combinaties. Een andere toekomstverkenner stelde dat "milieubewustzijn onhanteerbaar" is als keuze voor één van de assen en een ander begreep het besluit niet om "klimaatverandering weg te schuiven" terwijl volgens hem dat juist een thema voor de lange termijn was. "Juist door de verschijningsvorm met grote extremen" is klimaatverandering volgens hem een belangrijk thema voor de toekomst (Werkconferentie SCENE, 14 december 2001). Weer een ander gaf te kennen het kwadrant met lage economische groei en een groot milieubewustzijn "niet plausibel" te vinden, omdat hij het niet aannemelijk vond dat mensen in het milieu zouden investeren in tijden van economische malaise. Interessant is, hoewel de keuze van de assen bekritiseerd werd, zij het werken met een assenstelsel zelf niet ter discussie stelden.

\footnotetext{
${ }^{35}$ Net als het assenstelsel als 'skelet' is ook 'fundering' een onderzoekersterm. Dus, hoewel de toekomstverkenners zelf ook verwezen naar het assenstelsel als fundering, gebruik ik deze term om te verwijzen naar deze tweede functionele betekenis van het assenstelsel die ik in het proces van toekomstverkennen op het spoor kwam.

${ }^{36}$ Dit waren in eerste instantie de deelnemers aan de werkconferentie.
}

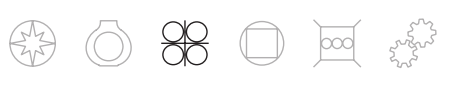


De toekomstverkenners die de manier waarop het assenstelsel (als skelet) werd gepresenteerd bekritiseerden, bleken een andere invulling te geven aan het assenstelsel. Zij zeiden namelijk het assenstelsel te beschouwen als "een fundament" of "fundering" voor het maken van scenario's en "structuur" voor de discussies en het maken van scenario's. Zij kozen ervoor afstand te nemen van de manier waarop het assenstelsel voorheen was ingezet en er een nieuwe betekenis aan te geven, namelijk als "gezamenlijk frame". Het assenstelsel werd dus vooral beschouwd als een processtructuur voor het verkennen van de toekomst. Deze toekomstverkenners die redeneerden volgens de funderingslogica stelden dat het assenstelsel niet meer en niet minder is dan een startpunt voor het maken van scenario's en positioneerden het assenstelsel heel expliciet als een "truc" om vier scenario's te ontwikkelen. Dit inzetten van het assenstelsel als processtructuur gebeurde bijvoorbeeld tijdens één van de werkconferenties die in het kader van deze toekomstverkenning werden georganiseerd ${ }^{37}$. Tijdens deze bijeenkomst werd het assenstelsel bijvoorbeeld gebruikt om de verschillende deelnemers in te delen in subgroepen. Elke subgroep kreeg een kleur, gekoppeld aan een kwadrant in het assenstelsel, een zaal en een procesbegeleider toegewezen en zo kon worden begonnen met het inkleuren van de scenario's.

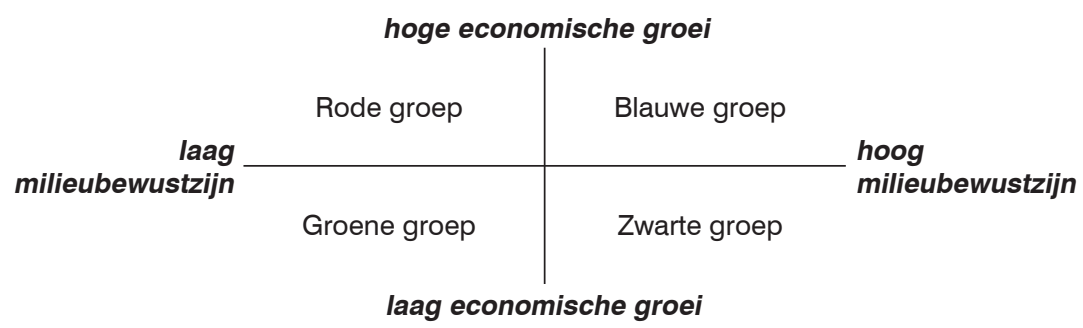

Fig. 3.6 - Het assenstelsel als basis voor een groepsindeling

\footnotetext{
${ }^{37}$ Tijdens het scenarioproject organiseerden de toekomstverkenners twee werkconferenties waaraan verschillende vertegenwoordigers "uit het veld" deelnamen, zoals ambtenaren werkzaam bij gemeenten, provincies en ministeries, vertegenwoordigers van maatschappelijke organisaties en wetenschappers. De werkconferenties waren een eerste poging om scenario's te ontwikkelen op basis van het assenstelsel. Tijdens deze bijeenkomsten was het de bedoeling de verschillende scenario's causaal door te redeneren. De workshop resulteerde in uiteenlopende ideeën en suggesties voor de vier toekomsten in 2030: beschrijvingen van de algemene uitgangspunten van de scenario's, tekeningen en schetsen van de scenario's op geografische kaarten, trefwoorden, suggesties voor scenarionamen en cartoons die door professionele tekenaars waren gemaakt en waarin discussies tijdens de werkconferenties werden verbeeld. Daarnaast schreven de procesbegeleiders van de verschillende groepjes op basis van de discussies in hun subgroepen elk een uitgebreid rapport waarin zij verslag deden van wat het werken in hun subgroep had opgeleverd. Deze workshop output beschouwden de toekomstverkenners als "eerste bouwstenen" voor het inkleuren van de vier scenario's.
} 
Op het moment dat de assen waren gedefinieerd kreeg het assenstelsel dus een nieuwe functionele betekenis, namelijk als 'fundering' voor het proces van toekomstverkennen. De toekomstverkenners leken er dus in geslaagd te zijn een assenstelsel te construeren dat kon functioneren als structuur voor het ontwikkelen van verschillende verhalen over de toekomst, maar dan moest wel het assenstelsel als skelet worden losgelaten.

De toekomstverkenners die het assenstelsel beschouwden als fundament voor het maken van scenario's onderstreepten het belang van het betrekken van verschillende vertegenwoordigers van het ruimtelijke beleid bij het scenarioproces. Deze toekomstverkenners stelden naast 'impact' en 'onzekerheid' nog een nieuw selectiecriterium, namelijk 'draagvlak' en in het bijzonder die van vertegenwoordigers van het ruimtelijke beleid. Een van hen beschreef het assenstelsel als "het fundament voor verder werken" en stelde dat het daarom belangrijk is dat er draagvlak is voor de gekozen assen. Er moest volgens hem dus "goed over nagedacht" worden. Met opmerkingen als deze suggereerden de toekomstverkenners dat de belangrijkste en de meest onzekere drijvende krachten niet 'bestaan', maar dat zij "een keuze" zijn en daarmee de uitkomst zijn van een sociaal proces. Omdat het assenstelsel met de assen economische groei en milieubewustzijn volgens de toekomstverkenners bij de mensen in het veld het meeste draagvlak had, werd besloten dit assenstelsel te nemen als startpunt voor het maken van scenario's. Zo stelde één van de toekomstverkenners:

\footnotetext{
"Er wordt besloten uit te gaan van de twee driving forces zoals ze uit de Delphi zijn gekomen. Voor een discussie is een startpunt nodig. Deze twee driving forces werden in de Delphi het meest genoemd. Er is dus een draagvlak om met deze driving forces te beginnen (Projectbijeenkomst SCENE, 14 december 2001).
}

Het belang dat deze toekomstverkenners hechtten aan het creëren van draagvlak beïnvloedde ook de manier waarop de toekomstverkenners in de eindrapportage over het assenstelsel communiceerden. Eén van de argumenten die door de aanhangers van de funderingsbenadering naar voren werd gebracht was dat zij in hun rapporten tegemoet zouden moeten komen aan de verwachtingen van de deelnemers aan de werkconferentie die, aldus de verkenners, "verwachten dat zij als projectteam iets met het assenstelsel hebben gedaan". Om tegemoet te komen aan hun verwachtingen en om "verwarring" te voorkomen stelden deze toekomstverkenners voor het assenstelsel expliciet terug te laten komen in de rapportage. Ook benadrukte zij het belang van het transparant houden van de methode. Een van hen stelde dat "het assenstelsel nu eenmaal sturend" was geweest in het proces, dat de assen hebben gewerkt als "structurerend kader" en dat het daarom belangrijk is de gebruikte methode transparant te houden. "Men moet weten wat we gedaan hebben". De aanhangers van de funderingsbenadering lijken te vrezen dat als het assenstelsel zou worden losgelaten de scenario's als een kaartenhuis in elkaar zou storten, net zoals een huis verzakt zonder solide fundering.

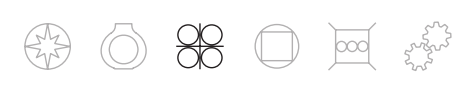


Ook in één van de vier achtergrondrapporten weerklinkt het funderingsideaal als de auteur uitlegt dat de twee drijvende krachten "betrekkelijk vrij" zijn gebruikt en dat het uitgangspunt daarbij was dat de scenario's "voldoende verschillend" zouden zijn. Hij legt uit dat dit ertoe heeft geleid "dat de 'driving forces' binnen de scenario's op verschillende manieren geïnterpreteerd worden". Deze auteur maakt dus expliciet dat de positionering van de scenario's in de kwadranten tot op zekere hoogte dynamisch is. Omdat volgens de funderingslogica het assenstelsel een uitkomst is van een sociaal proces, wordt het assenstelsel niet, zoals in de skeletbenadering, beschouwd als bepalend voor het scenarionarratief, maar bepaalt het scenarionarratief de positie van het scenario in het kwadrant. Het assenstelsel wordt dus nog steeds gebruikt als basis voor het maken van scenario's, maar niet zoals in de skeletlogica, waarin het assenstelsel "the stories outcome" bepaalt (Schwartz, 1991: 101-2). De scenario's zijn dus nog steeds verbonden aan de twee assen, maar op een fundamenteel andere manier. De funderingsbenadering geeft meer flexibiliteit in de keuze van de assen en de relatie tussen kwadrant en scenario. Deze toekomstverkenners benadrukten dat de twee assen "niet te strikt" genomen kunnen te worden. Het volgende figuur, dat door de toekomstverkenners zelf is gemaakt, illustreert deze meer flexibele interpretatie van het assenstelsel.

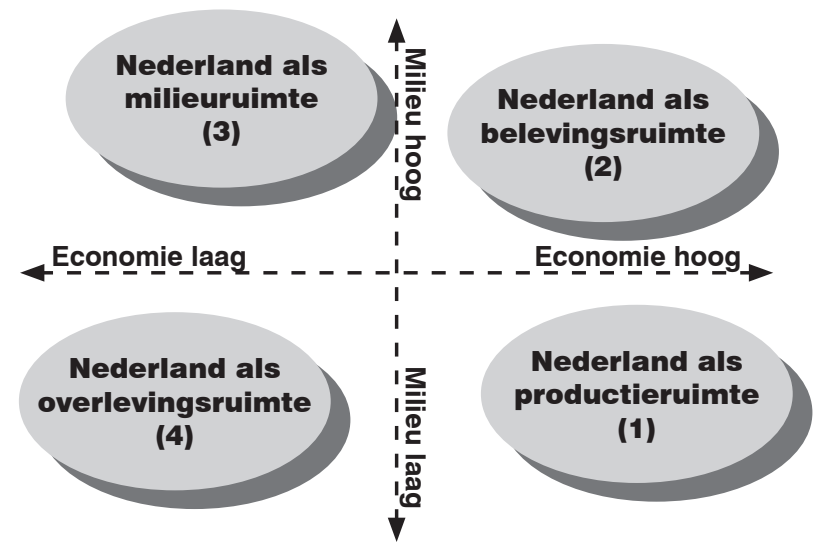

Fig. 3.7 - Het assenstelsel als fundering

In de toelichtende tekst bij deze figuur las ik dat het de bedoeling was om het assenstelsel "op een losse manier" te hanteren, want, zo stellen de verkenners:

"De economische groei kan in 'Nederland als productieruimte' bijvoorbeeld hoger zijn dan in 'Nederland als consumptieruimte' of omgekeerd. En milieubewustzijn kan in 'Nederland als milieuruimte worden uitgewerkt in de zin van het voldoen aan strenge milieunormen en in 'Nederland als consumptieruimte' als veel wonen in het groen, ook al leidt dat tot versnippering" (SCENE, Indicatoren voor de Scenario's, 2002). 
In deze figuur wordt het assenstelsel niet weergegeven als een 2x2-matrix, maar als een tweedimensionale ruimte. De twee assen representeren niet, zoals in de skeletlogica, de tegenstellingen hoog-laag, maar worden gebruikt als een soort glijdende schaal van hoog naar laag waarbinnen niet slechts vier maar verschillende toekomsten denkbaar zijn. Het assenstelsel wordt dan gebruikt om vier scenario's in een tweedimensionale ruimte te positioneren. Dus in de funderingsbenadering verandert de betekenis van het assenstelsel, omdat er meerdere toekomsten mogelijk zijn binnen een kwadrant. 'Variatie' tussen de scenario's krijgt dus binnen dit perspectief een heel andere betekenis dan binnen de skeletlogica: variatie wordt dus niet bepaald door het assenstelsel zelf, maar wordt ingegeven vanuit het scenarionarratief. Daarmee erkennen de toekomstverkenners dat het ook anders had kunnen zijn.

\section{Het assenstelsel als 'bouwstelling'}

Een aantal toekomstverkenners stelde echter zowel de skelet- als de funderingsbenadering openlijk ter discussie (wel in andere woorden: het assenstelsel als skelet en als fundering zijn, zoals ik eerder heb aangegeven, onderzoekstermen). Deze toekomstverkenners mobiliseerden de metafoor van het assenstelsel als bouwstelling of bouwsteiger bijvoorbeeld door te stellen dat het assenstelsel "alleen maar bedoeld is als 'bouwstelling' voor de scenario's". De toekomstverkenners die dit perspectief aanhingen brachten naar voren dat het afbreken van de bouwstelling hen beter in staat zou stellen complexere en interessantere verhalen te vertellen over de toekomst. In deze functionele betekenis is het assenstelsel niet onlosmakelijk verbonden aan de vier toekomsten, maar een heuristiek die toekomstverkenners helpt variatie tussen de scenario's te realiseren. Het assenstelsel werd dus nog steeds gezien als een bruikbare techniek om de scenario's in de steigers te zetten, maar deze functie verdwijnt daarna en kan zelfs een obstakel worden als het niet wordt los- en weggelaten. Zo stelde één van de voorstanders van deze derde benadering:

"Dit assenstelsel had in het begin van het project een belangrijke functie, maar nu moet er niet meer te sterk aan vastgehouden worden. Het moet worden gezien als een bouwsteiger. Nu het bouwwerk af is, kan de steiger worden weggehaald" (Projectbijeenkomst SCENE, 2 april 2002).

Zij benadrukten dus de tijdelijke bruikbaarheid van het assenstelsel als hulpmiddel en stelden dat, als het assenstelsel zijn werk gedaan heeft, namelijk als de vier scenario's stevig in de steigers staan, deze weer zou moeten worden afgebroken:

"Als we de scenario's verder hebben ingevuld en hebben gecontroleerd op consistentie en contrast, dan zouden we de assen zelfs los moeten laten (zoals je een bouwstelling afbreekt op het moment dat het huis er staat). Het vraagstuk van de juiste driving forces

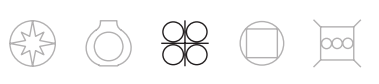


is dan als het goed is ook opgelost, omdat we zorgen dat allerlei trends - economie, milieubewustzijn, demografie, politiek, etc. - in elk scenario een andere kant opwijzen" (Projectbijeenkomst SCENE, 29 januari 2002).

Deze toekomstverkenners zetten dus de metafoor van een bouwstelling in om te beargumenteren waarom de assen losgelaten én weggelaten zouden moeten worden. Het achterliggende idee was namelijk dat je een bouwstelling ook niet laat staan als het huis eenmaal is gebouwd.

De toekomstverkenners brachten verschillende argumenten in om het assenstelsel losen weg te laten. Een belangrijke motivatie bleek de integratieambitie te zijn. Zo stelden zij dat "andere variabelen" dan economische groei en milieubewustzijn in de uiteindelijke scenario's "minstens zo belangrijk" waren en dat "voorop komt te staan dat we integrale scenario's hebben gemaakt". Hun voorstel was daarom niet alleen economische groei en milieubewustzijn te variëren, maar ook variabelen als politiek, technologie en demografie. Voorstanders van deze benadering gebruikten de volgende afbeelding om deze variatie tussen de scenario's, los van het assenstelsel, te illustreren:

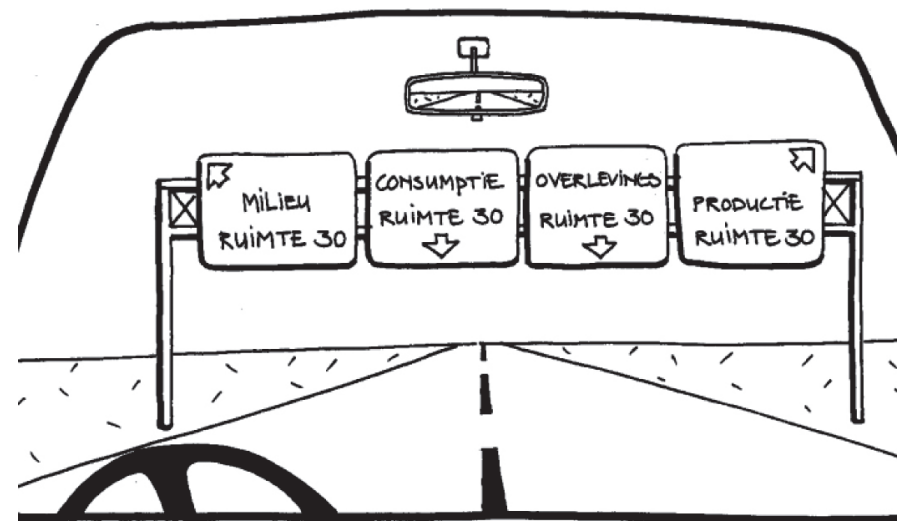

Fig. 3.8 - Scenario's 'los' van het assenstelsel

Het denken in twee dimensies is volgens de bouwstellinglogica problematisch, omdat het toekomstverkenners ervan zou weerhouden de complexe dynamiek van het systeem voor beleidsmakers hanteerbaar te maken. Deze toekomstverkenners zeiden daarbij het assenstelsel te ervaren als een harnas en beargumenteerden dat het assenstelsel helemaal losgelaten zou moeten worden om meer ruimte te kunnen geven aan het integrale karakter van de scenario's. Dit perspectief is dus fundamenteel anders, omdat het er nu niet om gaat de twee drijvende krachten "betrekkelijk vrij" te interpreteren en te 
gebruiken, maar om het assenstelsel te gebruiken als één "hulpmiddel om scenario's te maken die daadwerkelijk verschillende richtingen uitwijzen" en daarna de scenario's als het ware helemaal los te maken van het assenstelsel. Dus ten behoeve van het krijgen van integraliteit moesten de toepassingen van het assenstelsel als skelet en fundering sneuvelen. We zien hier dat de manifestatie van de integratieambitie invloed heeft op het 'doen' van variatie.

Anderen motiveerden het los- en weglaten van het assenstelsel door expliciete te wijzen naar de skeletmythe. In hun ogen was het assenstelsel zoals dat door anderen, dus conform de skelet- of de funderingslogica, werd gebruikt "te mechanisch" en stelden dat het niet wenselijk was "de rijkheid van de scenarioverhalen plat te slaan tot twee dimensies". We zien hier dat deze toekomstverkenners de skeletmythe erkennen.

Een toekomstverkenner zei te willen voorkomen dat het assenstelsel "een eigen leven gaat leiden". En een ander besloot zelfs de keuze van de twee assen in twijfel te trekken door te stellen dat de drijvende krachten collectiviteit en individualiteit misschien een betere keuze waren geweest. Dit is opvallend, want als het assenstelsel niet meer is dan een heuristiek dan is de vraag of de assen al dan niet plausibel of goed gekozen zijn niet relevant. Dit argument is dus in tegenspraak met de bouwstelling logica en conform de skeletmythe. Het inzetten van skeletvocabulaire om het belang van bouwstelling benadering te onderstrepen kan echter ook begrepen worden als een strategische zet om de tegenstanders te overtuigen ${ }^{38}$.

Deze bouwstelling benadering komt ook tot uitdrukking in het vierde achtergrondrapport, wat bijvoorbeeld blijkt uit de manier waarop de auteur het integrale karakter van de scenario's benadrukt. Hij legt bijvoorbeeld uit dat "de scenario's zijn opgebouwd uit vele sociale, economische, politieke en ruimtelijke elementen" en dat er "los" van het assenstelsel "keuzen" zijn gemaakt "om de interne logica van de scenario's te versterken". In dit rapport wordt het assenstelsel dus gepositioneerd als heuristiek om integrale scenario's te ontwikkelen. In dit rapport wordt het assenstelsel nog wel genoemd en is dus wel losgelaten, maar niet 'weg'.

Ook in het hoofdrapport wordt het assenstelsel slecht twee keer genoemd. De eerste verwijzing vond ik in het hoofdstuk over de werkwijze. Hier wordt opgemerkt dat op basis van twee in de werkconferenties geselecteerde drijvende krachten een assenstelsel is gemaakt "dat diende als vertrekpunt voor de vier scenario's" en dat de

${ }^{38}$ Thompson, Ellis, \& Wildavsky (1990) hebben dit fenomeen, waarbij het vocabulaire van een ander perspectief wordt ingezet om strategische redenen, aangeduid met de term "stolen rhetoric". Mesman (2002) laat zien dat er in de praktijk zelden sprake is van wat zij noemt "repertoirezuiverheid" en dat repertoires niet persoonsgebonden zijn. Mensen blijken bewust of onbewust verschillende repertoires door elkaar te gebruiken.

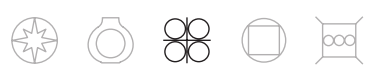


drijvende krachten vervolgens weer zijn losgelaten omdat het assenstelsel bedoeld was "als bouwstelling om de scenario's te positioneren en om ervoor te zorgen dat zij daadwerkelijk vier verschillende richtingen zouden uitwijzen" (RPB, 2003b: 19). En in het hoofdstuk 'aandachtspunten en kennisvragen' las ik dat de scenario's "op een samenhangende manier het mogelijke verloop van uiteenlopende maatschappelijke ontwikkelingen in beeld" brengen en dat het dus niet alleen gaat om "de assen" 'economische groei' en 'milieubewustzijn', maar om het leggen van verbanden tussen "ruimtelijke ordening, milieu, mobiliteit, natuur, landbouw (èn, sk) economie" (RPB, 2003b: 107). Ook las ik dat een belangrijk uitgangspunt was bij het maken van scenario's dat zij verschillende ontwikkelingen "op een samenhangende manier" in beeld te brengen met het doel "de complexiteit en dynamiek die beleidsmakers ervaren" beter hanteerbaar te kunnen maken (RPB, 2003b: 107). De auteurs van dit rapport benadrukken het integrale karakter van de scenario's en stellen dat scenario's die zich baseren op slechts twee drijvende krachten minder goed aansluiten bij de complexe en dynamische belevingswereld van de gebruikers van de scenario's. Hier mobiliseren zij dus de integratieambitie om het naar voren schuiven van het assenstelsel als bouwstelling te legitimeren. Het assenstelsel is ook op een andere manier niet helemaal afwezig. Hoewel op de kaft van het rapport het assenstelsel zichtbaar afwezig is worden de vier toekomstbeelden nog steeds ten opzichte van elkaar gepositioneerd in een 2x2structuur:

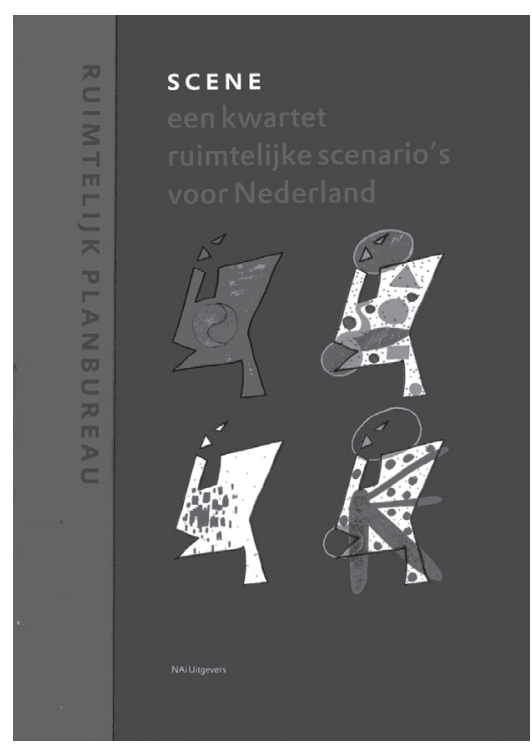

Fig. 3.9 - Kaft eindrapport SCENE 
Ik wil niet beweren dat skelet, fundering en bouwtelling de enige denkbare functionele betekenissen van het assenstelsel zijn. In het BETER-project van het Energieonderzoek Centrum Nederland (ECN) kwamen we bijvoorbeeld een vierde benadering van het assenstelsel tegen, namelijk het assenstelsel als 'vitrine'. In deze benadering wordt het assenstelsel ingezet als een tweedimensionale ruimte om reeds ontwikkelde toekomstbeelden ten opzichte van elkaar te positioneren en als middel om verschillen en overeenkomsten op te sporen en te communiceren. In deze toepassing kunnen de assen zogenaamde 'drijvende krachten' zijn, maar dat hoeft niet. De assen kunnen ook andere kenmerken van de toekomst representeren. Het assenstelsel als 'vitrine' is noch een legitimatie van de verhalen over de toekomst (zoals in de skeletbenadering), noch een uitkomt van een sociaal proces (zoals in de funderingsbenadering), maar, zoals de bouwstellingbenadering een heuristiek om inzicht te krijgen in de variëteit in een set van scenario's. Naast het assenstelsel als skelet, fundering, bouwstelling en vitrine zijn vast nog andere functionele betekennissen denkbaar.

\subsection{Variatie over variatie}

In de praktijk van toekomstverkennen wordt het assenstelsel opgevat als een variatieinstrument. Een variatie-instrument waar in de literatuur over toekomstverkennen naar verwezen werd als een 'standaard'. Ik heb echter laten zien dat toekomstverkenners in de praktijk van toekomstverkennen dit variatie-instrument verschillende functionele betekenissen geven. Er is dus 'variatie over variatie'.

Tijdens de scenario-exercitie vond veel discussie plaats tussen voorstanders van de funderingsbenadering en toekomstverkenners die het assenstelsel beschouwden als bouwstelling. Er werden verschillende afwisselend methodologische, sociale, hiërarchische, emotionele, inhoudelijke en procesargumenten aangevoerd om het assenstelsel te behouden dan wel te laten verdwijnen uit de rapporten. Geen van de actoren slaagt erin de ander voor zich te winnen. Daarom blijven de verschillende functionele betekenissen gedurende de hele verkenningsexercitie actief en naast elkaar bestaan.

Elk van deze functionele betekenissen werpt een ander licht op de variatieambitie in de praktijk. In de skeletbenadering wordt variatie beschouwd als een eigenschap van het in beschouwing zijnde systeem. Variatie in toekomstbeelden wordt daarmee bepaald door de twee belangrijkste en meest onzekere ontwikkelingen die het toekomstige verloop van het systeem sturen. In de skeletbenadering variëren toekomstverkenners dus slechts twee drijvende krachten in de ontwikkeling van het scenario. Werken met het assenstelsel volgens de skeletlogica impliceert dat veel moet worden geïnvesteerd in het 'ontdekken' van de belangrijkste en meest onzekere krachten achter de ontwikkeling van het systeem.

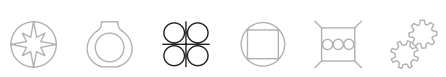


Volgens deze variatiebenadering kan variatie worden 'gevonden' of 'ontdekt' door middel van gedegen, systematische analyse en een goed begrip van de werking van het systeem. De suggestie is dus dat vakkundig zoeken en verzamelen van informatie de toekomstverkenners uiteindelijk tot de twee drijvende krachten zal brengen en dat, als deze uiteindelijk zijn gevonden, het assenstelsel niet zomaar een structuur is voor het maken van scenario's, maar de enige structuur. De twee assen die de tegenstellingen hoog-laag representeren worden, met andere woorden, beschouwd als bepalend voor het scenarionarratief. Het assenstelsel wordt in deze benadering gevisualiseerd als een 2x2-matrix met vier kwadranten en dus vier scenario's. Variatie is dus in deze functionele betekenis beperkt tot vier mogelijke toekomstbeelden.

Voor anderen representeren de twee drijvende krachten niet alleen een systeem, maar ook een keuze, een compromis en uitkomst van een sociaal proces. Variatie wordt in dit perspectief niet alleen bepaald door de twee belangrijkste en meest onzekere drijvende krachten, maar ook ingegeven vanuit een door actoren (gezamenlijk) geschreven scenarionarratief. Voor toekomstverkenners die uitgaan van deze functionele betekenis betekent 'variatie' dat er oneindig veel scenario's mogelijk zijn, maar dat deze wel binnen hoekpunten begrensd zijn. En wat die hoekpunten zijn en welke scenario's daarbinnen het meest relevant zijn wordt ingegeven door de stem van de meerderheid. Dissidente, afwijkende standpunten worden gemarginaliseerd. In deze benadering betekent variatie dus niet alleen variatie in de set van toekomstbeelden (zoals in de eerste functionele betekenis), maar ook, vanwege onzekerheid, in de interpretatie van de drijvende krachten. In deze funderingsbenadering wordt het assenstelsel daarom nog steeds gebruikt als basis voor het maken van scenario's, maar niet zoals volgens de skeletlogica, waarin het assenstelsel "the stories outcome" volledig bepaalt (Schwartz, 1991: 101-2). In de funderingslogica zijn de scenario's nog steeds verbonden aan de twee assen, maar op een fundamenteel andere manier: niet het assenstelsel is bepalend voor het scenarionarratief, maar het scenarionarratief bepaalt de positie van het scenario in het kwadrant. De funderingsbenadering geeft, met andere woorden, meer flexibiliteit in de keuze van de assen en de relatie tussen kwadrant en scenario. Het assenstelsel wordt om deze reden niet weergegeven als een 2x2-matrix, maar als een tweedimensionale ruimte. De twee assen representeren niet, zoals in de skeletlogica, de tegenstellingen hoog-laag, maar worden gebruikt als een soort glijdende schaal van hoog naar laag waarbinnen niet slechts vier maar verschillende toekomsten denkbaar zijn. Het assenstelsel wordt dan gebruikt om vier scenario's in een tweedimensionale ruimte te positioneren. Dus in de funderingsbenadering verandert de betekenis van het assenstelsel, omdat er meerdere toekomsten mogelijk zijn binnen een kwadrant. Daarmee erkennen de toekomstverkenners dat het ook anders had kunnen zijn.

Weer anders is dit in de derde variatiebenadering. Dit derde type toekomstverkenners beschouwt variatie namelijk niet als een eigenschap van een systeem of als compromis tussen betrokken actoren, maar als iets dat wordt 'gemaakt' door de 
toekomstverkenners. In deze bouwstelling-benadering van het assenstelsel wordt het assenstelsel beschouwd als "hulpmiddel om scenario's te maken die daadwerkelijk verschillende richtingen uitwijzen". In deze functionele betekenis is het assenstelsel niet onlosmakelijk verbonden aan de vier toekomsten, maar een heuristiek die toekomstverkenners helpt de variatie in de set van de scenario's te realiseren. Het assenstelsel wordt dus nog steeds gezien als een bruikbare techniek om de scenario's in de steigers te zetten, maar deze functie verdwijnt daarna. Als die bouwstelling eenmaal is afgebroken hoeft ook niet langer vastgehouden te worden aan de set van vier toekomstbeelden, maar kunnen het er ook meer of minder zijn. Variatie wordt dus niet bepaald door het assenstelsel zelf, maar wordt ingegeven vanuit het scenarionarratief en wordt daarmee 'gemaakt' door de toekomstverkenners. En dit is mogelijk vanwege het erkennen van onzekerheid in de brede zin. Dit impliceert dat er niet alleen variatie is in toekomstbeelden (skeletmythe en funderingslogica) of in twee drijvende krachten (funderingslogica), maar dat alle variabelen in het beschouwde systeem kunnen variëren (zie tabel 3.2 voor een samenvatting van de drie functionele betekenissen).

In de SCENE-toekomstverkenning bleek variatie over variatie de "status-quo" te zijn. Niet alleen tijdens de verkenningsexercitie, maar zelfs in de eindrapportage bleven verschillende functionele betekenissen van het assenstelsel naast elkaar bestaan. Uit de verschillende manieren waarop de toekomstverkenners over het assenstelsel spraken en de manier waarop zij het assenstelsel visualiseerden blijkt dat er tot het eind geen sprake is van een "fixity of meanings" (Bijker, 1995). Er bleek geen consensus te bestaan over de functionele betekenis van het assenstelsel in het SCENE-project. Er was dus sprake van methodische variatie. Toch leidde het ontbreken van consensus niet tot een impasse. Terwijl de strijd over het assenstelsel voortduurde, vormde het ontbreken van overeenstemming geen obstakel voor het verdere verloop van het project.

Dit fenomeen van methodische variatie vanwege verschillende functionele betekenissen van (hulp)middelen, waarbij de toepassing van methoden sterk varieert tussen verschillende gebruikers, is geen uniek toekomstverkenningsfenomeen, maar werd ook in andere praktijken van kennisproductie waargenomen. Zo constateren Jordan \& Lynch (1992) bijvoorbeeld in hun publicatie over de werking van een techniek die veelvuldig wordt gebruikt in genetisch onderzoek dat de toepassing van die techniek sterk varieert "from practitioner to practitioner, and even from one performance to the next" (Jordan \& Lynch, 1992: 81). Jordan en Lynch (1992) verwijzen naar deze methodische variatie met de term "autoreification" en constateren dat "variation is both a matter of solitary circumstances in which each practitioner works out a method and the sequestering of personal variations once they are established" (100-1). Volgens deze auteurs kan deze variatie bestaan bij de gratie van een veronderstelde gedeelde en eenduidige praktijk en het geloof in een ultieme rationaliteit van de gehanteerde procedures. Deze procedures blijven stabiel zo lang als "its identity as such remains unrecognized or misrecognized" (92).

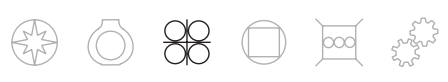




\begin{tabular}{|c|c|c|c|}
\hline Assenstelsel als: & Skelet & Fundering & Bouwstelling \\
\hline Synoniemen & Basis, fundament & $\begin{array}{l}\text { Basis, fundament, } \\
\text { gezamenlijk 'frame'/ } \\
\text { kader, processtructuur }\end{array}$ & $\begin{array}{l}\text { Bouwsteiger, heuristiek, } \\
\text { hulpmiddel }\end{array}$ \\
\hline $\begin{array}{l}\text { Aantal drijvende } \\
\text { krachten }\end{array}$ & $\begin{array}{l}2 \text { (formele } \\
\text { selectiecriteria: impact } \\
\text { en onzekerheid) }\end{array}$ & $\begin{array}{l}\text { 2. (formele } \\
\text { selectiecriteria: impact, } \\
\text { onzekerheid, draagvlak) }\end{array}$ & $\begin{array}{l}\text { Meerdere } \\
\text { 'variabelen' (keuze } \\
\text { toekomstverkenners) }\end{array}$ \\
\hline Perspectief op 'variatie' & $\begin{array}{l}\text { •Eigenschap van het in } \\
\text { beschouwing zijnde } \\
\text { systeem } \\
\text { •Assenstelsel bepaalt } \\
\text { scenarionarratief } \\
\text { - Vier mogelijke } \\
\text { toekomstbeelden }\end{array}$ & $\begin{array}{l}\text {-Variatie als uitkomst } \\
\text { van sociaal proces } \\
\text { •Scenarionarratief } \\
\text { bepaalt positie van het } \\
\text { scenario in kwadrant } \\
\text { - Oneindig veel } \\
\text { mogelijke } \\
\text { toekomstbeelden, } \\
\text { maar binnen } \\
\text { hoekpunten begrensd } \\
\text { •Keuze van vier, bepaald } \\
\text { door 'de stem van de } \\
\text { meerderheid' }\end{array}$ & $\begin{array}{l}\text {-Variatie als keuze } \\
\text { - Niet per se vier } \\
\text { toekomstbeelden; } \\
\text { kunnen er ook meer of } \\
\text { minder zijn }\end{array}$ \\
\hline $\begin{array}{l}\text { Representatie } \\
\text { assenstelsel }\end{array}$ & 2×2-matrix & 2-dimensionale ruimte & $\begin{array}{l}\text { Geen (of impliciete } \\
\text { verwijzing) }\end{array}$ \\
\hline
\end{tabular}

Tabel 3.2 - Samenvatting van de drie functionele betekenissen

In de SCENE praktijk van toekomstverkennen zien we echter dat de verkenners de identiteit van het assenstelsel wel degelijk ter discussie stellen. Er lijkt noch sprake van een veronderstelde gedeelde eenduidig praktijk noch van een geloof in een ultieme rationaliteit, waardoor de betekenis van het assenstelsel voor de scenario-exercitie (als skelet, fundament of bouwstelling) een voortdurend punt van onderhandeling is. De analyse laat zien dat voortgang in toekomstverkenning niet verklaard kan worden door het toepassen van een simpele, eenduidige (standaard)techniek, het geloof in een ultieme rationaliteit van gehanteerde procedures of een gedeelde veronderstelling van een eenduidige praktijk.

In de SCENE toekomstverkenning bestaan verschillende opvattingen ten aanzien van variatie naast elkaar. Deze 'variatie over variatie' werd in het proces van toekomstverkennen wel 'herkend', maar in de eindrapportage niet 'erkend'. Dus, hoewel de variatieambitie het startpunt was van de toekomstverkenners betekende 
dit niet dat de verschillende methodologische interpretaties ook een plek kregen in de toekomstverkenning. De toekomstverkenners streefde, daarentegen, voortdurend naar uniformiteit in de externe communicatie over de gehanteerde methodologie. In het eindrapport komt alleen de bouwstellingbenadering van het assenstelsel tot uitdrukking (het perspectief van de projectleider en eerste auteur van het rapport). Alternatieve interpretaties werden gemarginaliseerd en verdwenen zo goed als uit de eindrapportage. Deze variatie is nog wel zichtbaar als je het gepubliceerde rapport naast de deelrapporten legt. Mede daarom is gepoogd deze rapporten (en dus de methodische variatie) uit het zicht te houden, onder andere door het besluit deze rapporten niet uit te brengen als RPB-rapport.

\subsection{Van variatie naar integratie}

De toekomstverkenners hadden het assenstelsel ingezet om variatie te bewerkstelligen. Echter, vanwege het ontstaan van 'variatie over variatie' wordt het gebruik van het assenstelsel als variatie-instrument problematisch, waardoor het realiseren van de variatieambitie lijkt te worden bemoeilijkt.

Om dit probleem op te vangen en de impasse te doorbreken mobiliseerde sommige toekomstverkenners, waaronder de projectleider, een ambitie die anders was dan de oorspronkelijke ambitie, maar die ook appelleert aan de 'nieuwe' toekomstoriëntatie, namelijk de integratieambitie. Zij stelden namelijk dat "andere variabelen" dan economische groei en milieubewustzijn in de uiteindelijke scenario's "minstens zo belangrijk" waren en dat "voorop komt te staan dat we integrale scenario's hebben gemaakt". Hun voorstel was daarom niet alleen economische groei en milieubewustzijn te variëren, maar ook variabelen als politiek, technologie en demografie. Daarbij benadrukten zij dat het denken in twee dimensies de toekomstverkenners ervan zou weerhouden de complexe dynamiek van het systeem voor beleidsmakers hanteerbaar te maken. Vanuit dit perspectief was het dus noodzakelijk om meer ruimte te geven aan het integrale karakter van de scenario's. Dus ten behoeve van het krijgen van integraliteit moesten de toepassingen van het assenstelsel als skelet en fundering sneuvelen. Door 'integratieambitie' te mobiliseren kon uiteindelijk alsnog de keuze voor een van de drie functionele betekenissen worden gelegitimeerd.

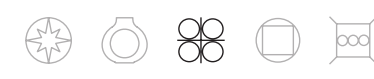



( 34
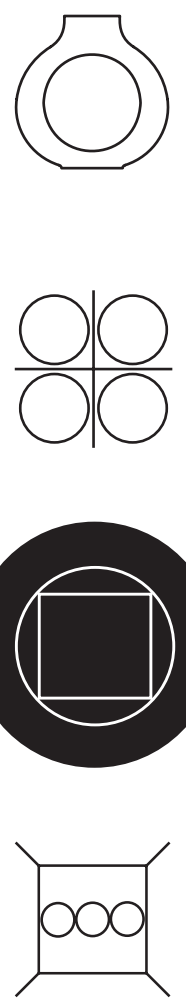

5 


\section{(4) De integratieambitie: bruggen bouwen en grenzen trekken}

Voor een nieuwkomer in de praktijk van toekomstverkennen lijkt het verkennen van de toekomst vooral te draaien om het integreren van verschillende thema's, perspectieven en disciplines. Menig handboek bepleit een holistisch perspectief. Het achterliggende idee is dat alles zo met elkaar verbonden is, dat subsystemen alleen maar in relatie met andere subsystemen kunnen worden begrepen. In het handboek Foundations of Futures Studies stelt Bell (2000) bijvoorbeeld dat "the interdependence of the world invites a holistic perspective" (155). Toekomstverkennen wordt in de literatuur daarom vaak vergeleken met het maken van een puzzel: door het in elkaar passen van verschillende thema's, sectoren, schaalniveaus en wetenschappelijke disciplines zou een geheel ontstaan dat meer is dan de som der delen. Met vergelijkingen als deze worden toekomstverkenners aangespoord in hun werk te streven naar een holistisch perspectief op de toekomst. Uit de literatuur blijkt dat integratie een theoretische ambitie is.

Niet alleen in de literatuur over toekomstverkennen, maar ook in de praktijk zijn "integraal", "geïntegreerd" en "integratie" centrale termen ${ }^{39}$. Als ik er een aantal rapporten op nasla, dan ontkom ik niet aan de indruk dat veel toekomstverkenners zichzelf de taak stellen een allesomvattend perspectief te vinden waarin verschillende subsystemen met elkaar in verband kunnen worden gebracht. Integratie blijkt dan te verwijzen naar zowel een attribuut van de toekomstbeelden als naar de werkwijze (dus hoe toekomstverkenners de toekomst verkennen). In het SCENE rapport wordt bijvoorbeeld gesteld dat de beschreven scenario's "integraal" zijn omdat zij uiteenlopende ontwikkelingen in beeld brengen (RPB, 2003b: 7) (integratie als attribuut). En in het planbureaubrede document 'Speerpunten Ruimtelijk Planbureau' las ik dat het een ambitie is van het RPB te "komen tot een integratie van ontwerp en onderzoek, zowel binnen projecten (..) als binnen het planbureau als geheel". Hier verwijst de integratieambitie, met andere woorden, naar een (RPB) wijze van werken. Integratie lijkt dus ook te worden gezien als een manier om over disciplinaire grenzen heen te kunnen kijken. Integraliteit is voor toekomstverkenners in de door mij bestudeerde praktijk dus een expliciete ambitie.

Integratie is dus een centrale notie in de praktijk van toekomstverkenning en zegt iets over wat toekomstverkenners (proberen te) doen! De term "integratie" lijkt in de praktijk van toekomstverkennen dus een zeker gedeeld commitment uit te drukken. Toch wordt

\footnotetext{
${ }^{39}$ De integratieambitie lijkt in de praktijk ook tot uitdrukking te komen in het gebruik van termen als "samenhang", "synthese" en "coherentie". Deze termen verwijzen naar integratie als attribuut van de toekomstbeelden. In het SCENE-rapport las ik bijvoorbeeld over de scenario's dat zij nieuwe verbanden leggen tussen verschillende thema's en dat zij "op een samenhangende manier" mogelijke toekomstige ontwikkelingen in beeld brengen (RPB, 2003b: 12). En in Nederland 2030 dat vier perspectieven op toekomstig Nederland "met elkaar in samenhang gebracht" worden (RPD, 1997: 7).
} 
er in de literatuur en de rapporten uit de praktijk nauwelijks gereflecteerd op vragen als 'wat is integratie?', 'hoe kom je tot integratie?', 'wat wordt er geïntegreerd?'. Van deze ambitie lijkt een soort vanzelfsprekendheid uit te gaan die nadere uitleg, definitie of debat overbodig maakt. In de linguïstische traditie wordt naar deze abstracte, maar sterk ingebedde begrippen verwezen met de term "ideograaf". Deze term werd voor het eerst geïntroduceerd door McGee (1980), die de volgende omschrijving gaf: "An ideograph is an ordinary language term (..) a high order abstraction, representing collective commitment to a particular but equivocal and ill-defined normative goal. It warrants the use of power, excuses behavior and belief (..) and guides behavior and belief into channels easily recognized by a community as acceptable and laudable (15), geciteerd in van Lente (1993). Auteurs als McGee (1980) en van Lente (1993) stellen dat van ideografen een krachtige structurerende werking uit kan gaan, omdat het vocabulaire van concepten dat met ideografen gepaard gaat fungeert als "guides, warrants, reasons, or excuses of behavior and belief" (McGee, 1980: 6). In de volgende paragraaf zal ik beschrijven welke betekenis(sen) toekomstverkenners in het project 'Verkenning van de Ruimte' (VVR) zowel impliciet als expliciet lijken te geven aan de integratieambitie. Hoe manifesteert de integratieambitie zich in de dagelijkse praktijk? Hoe en wat beogen de toekomstverkenners te integreren? In de paragrafen van 4.2 tot 4.6 beschrijf ik hoe toekomstverkenners de integratieambitie (proberen te) realiseren en welke structurerende werking er uit gaat van de integratieambitie.

\subsection{De integratieambitie in de VVR praktijk}

In het plan van aanpak van de WR toekomstverkenning formuleerden de toekomstverkenners de volgende ambitie, namelijk:

"De ambitie van de VVR is de toekomstige ruimtevraag van wonen, werken, water, mobiliteit, natuur en landbouw met bandbreedte in beeld te brengen" (VVR Plan van Aanpak, 13 maart 2002).

Het uiteindelijke doel, zo las ik, was te komen tot "integratie van alle onderzoeksresultaten van de WVR en de manier waarop zij dit wilden doen was door "integraal denken en werken" (WVR Plan van Aanpak, 13 maart 2002). Ik zal eerst de integratieambitie proberen te concretiseren en specificeren door te beschrijven en analyseren welke betekenissen de toekomstverkenners in het WR-project geven aan integratie en wat de toekomstverkenners beogen te integreren. Ik zal laten zien dat er in de WR-praktijk van toekomstverkennen verschillende integratieambities naast elkaar bestaan. Daarna, in paragraaf 4.2, zal ik ingaan op hoe de toekomstverkenners de integratieambitie(s) (proberen te) realiseren.

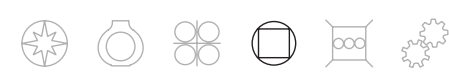




\section{Integratie $=($ meer dan $)$ de som der delen}

Wat beoogden de toekomstverkenners in het WR-project te integreren? Uit verschillende projectdocumenten en observaties uit die praktijk ontstaat de indruk dat integratie in eerste instantie betrekking heeft op het integreren van verschillende deelanalyses, namelijk Wonen, Werken, Natuur \& Water en Landbouw. De toekomstverkenners leken hun werkveld, namelijk ruimtelijke ordening, bij uitstek te beschouwen als een terrein dat vraagt om een integraal perspectief. Het beeld dat zij daarbij opriepen was het perspectief van een piloot die Nederland aanschouwt als een lappendeken van afwisselend water, woningen, industrieterreinen, natuur, grasland, snelwegen en parkeerplaatsen. De toekomstverkenners stelden dat het in het verkennen van de ruimte niet zozeer gaat om de "sectorale inzichten", maar vooral om "het totaalbeeld" (Projectbijeenkomst WVR, 4 november 2002). Integratie betekent hier dus 'de som der delen', namelijk de uitkomsten van de sectorale analyses opgeteld. Termen die de toekomstverkenners in deze context gebruikten waren "samenbrengen", "samenhang" en "functies combineren".

De toekomstverkenners stelden integraal ook op één lijn met "sectoroverstijgend" en zeiden integratie vooral te associëren met "een nieuwe manier van kijken". De suggestie was dat door verschillende sectorale inzichten met elkaar te combineren, gekomen kan worden tot "nieuwe combinaties waar je nog niet aan had gedacht of waar je blind voor was omdat je vanuit een bepaald straatje dacht". Het ging hen er dus niet alleen om de samenleving in vogelvlucht, in zijn geheel te overzien, maar ook om het zoeken naar nieuwe, slimme combinaties en inzichten die, vanuit een sectoraal perspectief, uit het zicht van de toekomstverkenner zouden blijven. Zij zeiden te verwachten dat integratie "iets nieuws" zou kunnen opleveren. Eén van de toekomstverkenners hoopte:

"dat we uiteindelijk niet eindigen met allerlei losse verhaaltjes, maar dat het een samenhangend geheel wordt. Ik verwacht dat we met z'n allen het totale product een meerwaarde geven" (Projectbijeenkomst VVR, 3 december 2002).

De suggestie was, dat, door verschillende thema's/ sectoren, schaalniveaus en wetenschappelijke disciplines te integreren, een geïntegreerd geheel zou ontstaan dat meer zou zijn dan de som der delen (Projectbijeenkomst WR, 6 mei 2003).

\section{Integratie $=$ afstemmen}

Hoe operationaliseerden de toekomstverkenners hun integratieambitie? Of, met andere woorden, hoe werd integratie van verschillende sectoren in de praktijk georganiseerd? De eerste stap die de WR-toekomstverkenners namen op weg naar integratie was het uitwerken van de sectorale analyses. Dit deden zij door de toekomstige situatie van 
Nederland voor de verschillende sectoren zo veel mogelijk kwantitatief uit te drukken door het "waarschijnlijke" verloop van ontwikkelingen vanuit het verleden en in het heden naar de toekomst (proberen) door te trekken ("extrapoleren"). Dit waren, onder andere, demografische ontwikkelingen, trends in woningvoorraad, vestigingsvoorkeuren van bedrijven, ruimtevraag naar bedrijventerreinen, etc. Om de tijd van historische data (tijdreeksen) op een systematische manier op te kunnen rekken naar de toekomst maakten de toekomstverkenners gebruik van computermodellen. Deze "modellen" zijn opgebouwd uit wiskundige vergelijkingen die afgeleid zijn van theoretische veronderstellingen over hoe het beschouwde systeem gedacht wordt te functioneren. De suggestie is dat deze modellen toekomstverkenners in staat stellen de wereld op een numerieke manier uit te drukken. In de toekomstverkenning worden verschillende sectorale rekenmodellen ingezet. De uitkomsten van deze modelberekeningen duiden de toekomstverkenners aan met de term "prognoses" die zij zelf omschrijven met termen als "betrouwbare", "waarschijnlijke" of bekende" maatschappelijke (toekomstige) ontwikkelingen die kwantitatief kunnen worden uitgedrukt en als "beschrijvingen die min of meer vast liggen" (VVR Plan van Aanpak, 13 maart 2002).

De toekomstverkenners kozen ervoor om voor elke deelanalyse van sectoren/thema's een individueel projectcontract op te stellen en elke analyse onder te brengen in een afzonderlijk deelproject met een eigen budget, eigen deskundigen en afzonderlijke modellen. Dus, in plaats van de verschillende thema's van meet af aan in samenhang te beschouwen, kozen zij voor een zogenaamde 'bottom up-benadering'(vergl.

(Snellen, 2004: 15). Dit betekent dat zij de sectorale analyses relatief onafhankelijk van elkaar lieten plaatsvinden en dat er werd gewerkt zonder een vooraf gedefinieerd gemeenschappelijke aanpak en kader van veronderstellingen. Echter, om te voorkomen dat het aan het einde van de rit de deelstudies te ver uit elkaar zouden gaan lopen en het niet meer mogelijk zou zijn om alsnog een gemeenschappelijke noemer voor integratie te vinden, besloten de toekomstverkenners wekelijks samen te komen om de stand van zaken in hun deelprojecten te bespreken. Ook organiseerden zij tijdens het project een aantal plenaire bijeenkomsten met het doel stil te staan bij de "aannames" die verschillende toekomstverkenners maakten in hun deelanalyses. Een aanname is niets anders dan een bepaalde interpretatie van een onzekere variabele of een onzekere relatie wordt gevonden in de toekomstverkenning. Een aanname wordt meestal vertaald naar bepaalde getallen of wiskundige vergelijkingen in een model. Zo stelt één van de toekomstverkenners:

"We moeten nu al inzicht krijgen in de kwalitatieve en kwantitatieve dingen die in de modellen gaan, zodat we, als we helemaal aan het eind zijn, weten welke aannames we aan het begin hebben gemaakt die van invloed zijn op wat er aan het eind uitkomt" (Projectbijeenkomst VVR, 3 december 2002).

De toekomstverkenners beoogden door middel van deze bijeenkomsten de aannames

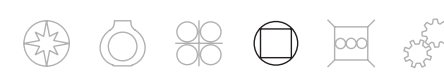


die werden gemaakt op sectoraal niveau te expliciteren om deze waar mogelijk te uniformeren en in een later stadium om de resultaten van de sectorale studies beter te kunnen duiden. De aannames, ook aangeduid als veronderstellingen, in de sectorale analyses lijken voor de toekomstverkenners een cruciale schakel in het doen van integratie. "Integratie" wordt hier dus nu geoperationaliseerd als de ambitie om "aannames"en "veronderstellingen" die de toekomstverkenners gebruiken in het uitwerken van de sectorale analyses te expliciteren en af te stemmen.

Met het vorderen van de sectorale analyses werd het "afstemmen"steeds concreter. Gingen de discussies in eerste instantie over abstracte "aannames"/"veronderstellingen", in tweede instantie richtten de toekomstverkenners hun blik steeds meer op het uniformeren van "tijdshorizonnen" en analyse-eenheden. (Met de term "tijdshorizon" verwijzen toekomstverkenners naar de tijdsspanne van hun toekomstverkenning. In de door mij geobserveerde praktijk van toekomstverkennen kozen de toekomstverkenners meestal voor een tijdshorizon tot 2020, 2030, 2040 of 2050. In Hoofdstuk vijf zal ik hier dieper op reflecteren). Afstemmen betekent nu dus het creëren van uniformiteit in tijdshorizonnen en analyse-eenheden. Dit zijn dus niet de deelanalyses zelf, maar de dimensies van de variabelen (dus de mate van detail en gedetailleerdheid) en de maat waarin de variabele wordt uitgedrukt (meters, hectaren, kilometers...).

\footnotetext{
"Er is heel veel verschillend materiaal, het gaat om heel veel verschillende sectoren. In de ene analyse gaat het over bevolking, aantal huishoudens en woonmilieus en in de andere arbeidsplaatsen, bedrijventerreinen en kantoorlocaties. Soms worden ontwikkelingen uitgedrukt in hectares, dan weer in reistijden... Hoe alles met alles samenhangt dat blijft één van de lastige punten" (Projectbijeenkomst VRR, 28 april 2003).

"Sommige analyses gaan uit van hectaren, anderen van reistijden, sommigen onderscheiden sectoren, weer anderen type huishoudens, woonmilieus of type maatregel. Als we dat niet uniformeren, dan zijn we appels met peren aan het vergelijken" (Projectbijeenkomst VVR, 6 mei 2003).
}

Maar hoe doen ze dit in concreto? Hoe construeren toekomstverkenners uniformiteit tussen heterogene tijdshorizonnen en analyse-eenheden? Om de verschillende sectorale inzichten te kunnen integreren maakten de toekomstverkenners een aantal vertaalslagen. Een stap was het gelijkstellen van de verschillende zichtjaren om de tijdshorizonnen te uniformeren. Sommige berekeningen liepen namelijk vanaf 2002 tot 2020, anderen van 1998 tot 2020 en weer anderen van 2003 tot 2050. De toekomstverkenners spraken af om alle prognoses tot 2040 te laten lopen. Doordat er alleen een eindpunt werd vastgelegd en niet een beginpunt werden de tijdshorizonnen dus eenzijdig geüniformeerd. De ambitie om alle resultaten op te tellen impliceert ook dat toekomstverkenners een manier moesten vinden om heterogene analyse-eenheden (zoals 'huishoudens', 'woningvoorraad', 'woonmilieus', 'formele bedrijventerreinen', 
'kantoorlocaties', etc.) met verschillende aggregaties (provincies, corops, regio's, gemeenten) en abstracties (absolute aantallen, relatieve verschillen) op een vergelijkbare manier uit te drukken (dus van 'appels' en 'peren' naar 'fruit'). Integreren betekent dus niet langer 'afstemmen' van aannames/veronderstellingen, maar de ambitie om dezelfde tijdshorizonnen en analyse-eenheden te gebruiken.

\section{Integratie $=$ optellen tot ruimtevraag}

De volgende stap die de toekomstverkenners namen in het verkenningsproces was het maken van zogenaamde "potentiekaarten". Deze kaarten beschouwden de toekomstverkenners, naast bovenbeschreven afstemming als een tweede integratieschakel.

Wat betekent dit? De toekomstverkenners spraken met elkaar af om alle sectorale kwantitatieve resultaten op eenzelfde manier uit te drukken, namelijk op een topografische kaart van Nederland. En om daar te komen construeerden de toekomstverkenners het concept "potentiekaart". Over potentie werd, voor zover dat in ieder geval voor mij zichtbaar was, voor het eerst expliciet gerept in het projectcontract, waarin wordt gesteld dat:

\footnotetext{
"Sommige regio's hebben op basis van de kenmerken van hun woon- en productiemilieu meer potenties dan andere. Als het ware zijn bepaalde gebieden attractiever voor verschillende ruimtelijke functies dan anderen. Ruimtevragende en zoekende functies zullen het liefste daar neerslaan waar hun wensen het beste worden gehoord" (VVR Projectcontract, 21 november 2001), onderstreping SK.
}

De toekomstverkenners karakteriseerden potentiekaarten later in de toekomstverkenning als "ruimtelijke vertalingen" van de sectorale prognoses op een kaart van Nederland. Integreren heeft dus de praktische betekenis gekregen van het letterlijk een plek geven van de sectorale prognoses op verschillende kaarten. Dit werd door het projectteam gevisualiseerd zoals op de volgende pagina is weergegeven (fig. 4.1).

De toekomstverkenners beschouwden de potentiekaarten als een tussenstap om uitspraken te kunnen doen over de "totale" toekomstige ruimtevraag in Nederland. De toekomstverkenners verwachtten dat het combineren van de kaarten hen inzicht zou geven in de totale toekomstige ruimtevraag en daarmee welke gebieden in de toekomst te kampen zullen hebben met hoge of lage ruimtedruk. Een hoge druk staat voor veel potenties in een bepaald gebied; laag voor weinig of één specifieke potentie. De toekomstverkenners zelf verwijzen naar deze gebieden die met hoge of lage druk te kampen hebben met de termen "hotspots" en "lowspots". Integratie is nu letterlijk het 'optellen' van aantallen hectares uit de sectorale prognoses en betekent inmiddels het 


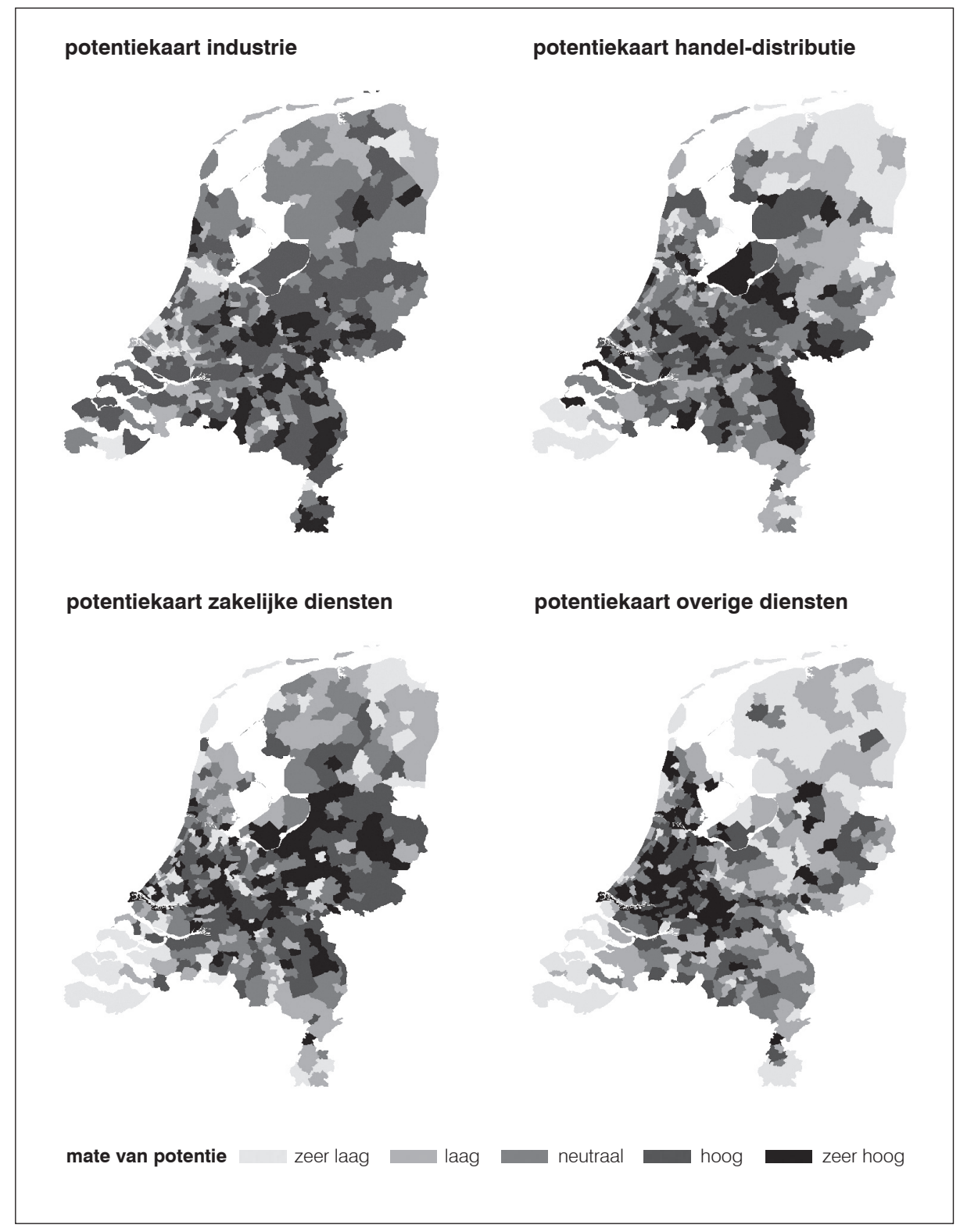

Fig. 4.1 - Voorbeeld potentiekaart (voor Werken, sector industrie) (bron: WVR Notitie RasterPlan) 
maken van potentiekaarten en die stapelen teneinde een praktisch integratiedoel $(=$ de totale ruimtevraag) te realiseren. Door de verschillende sectorale ruimteclaims te stapelen hoopten de toekomstverkenners een "integraal toekomstbeeld" te kunnen presenteren van de toekomstige ruimte in Nederland. En een "integraal toekomstbeeld" betekent in deze context het kunnen doen van uitspraken over de totale ruimtevraag van Nederland.

\section{Integratie $=$ combineren}

De toekomstverkenners bemerkten dat niet alle variabelen die van invloed zijn op de toekomstige ruimtevraag in cijfers kunnen worden uitgedrukt en een plek gegeven konden worden in de prognoses en de potentiekaarten. Daarom besloten zij naast de kwantitatieve analyses ook kwalitatieve analyses te doen. Deze kwalitatieve analyses duidden zij met de term "signalen". Deze zogenaamde "signalen" worden door de toekomstverkenners als volgt geïntroduceerd:

\footnotetext{
"Naast de kwantitatieve benadering van de prognoses worden in signalen de maatschappelijke ontwikkelingen uitgewerkt die enerzijds inzicht geven in de onzekerheden omtrent de prognoses (bandbreedte) en anderzijds die zaken behandelen die in de prognoses niet zijn meegenomen, maar die toch een impact hebben op de ruimtevraag" (VVR Projectcontract, 21 november 2002: 5).
}

Door middel van deze kwalitatieve analyses beoogden de toekomstverkenners meer inzicht te krijgen in (onzekere) krachten die het veronderstelde trendmatige verloop van ontwikkelingen in de toekomst zouden kunnen ontwrichten.

Andere termen die de toekomstverkenners gebruikten om de signalen te beschrijven zijn: "interessante ontwikkelingen", "aansprekend", "vernieuwend", "ruimtelijk relevant" en "taboedoorbrekend". Voorbeelden van signalen die door het projectteam werden geïdentificeerd waren: de toekomstige behoefte in Nederland aan 'landelijk wonen' en 'tweede woningen', de effecten van 'vergrijzing' en 'buitenlandse migratie' en de invloed van ICT-ontwikkelingen op de ruimtelijk-economische dynamiek en het ruimtebeslag voor werken. Integratie krijgt hier dus een nieuwe dimensie, namelijk het beschrijven van signalen en deze kwalitatieve kennis combineren met de kwantitatieve kennis uit de prognoses. Integratie betekent hier, met andere woorden, het integreren van kwantitatieve en kwalitatieve kennis in de toekomstverkenning. Dit wordt geillustreerd in het volgende citaat, waarin één van de toekomstverkenners stelt:

"Waar we nu nog naar zoeken is de relatie tussen signaal en prognose. Dat we uiteindelijk niet eindigen met allerlei losse verhaaltjes, maar dat het een samenhangend geheel wordt" (Projectbijeenkomst VVR, 3 december, 2002).

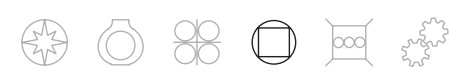


Integreren krijgt hier dus nogmaals een nieuwe invulling, namelijk het combineren van kwantitatieve en kwalitatieve inzichten en het ontwerpen van een manier waarop ze dat zouden kunnen doen.

\section{Integratie $=$ interdisciplinariteit}

In de loop van het WR-proces van toekomstverkennen werden twee culturen van toekomstverkennen zichtbaar. De ene groep toekomstverkenners positioneerde zichzelf als "analisten", "inhoudsdeskundigen" en "kwantitatievelingen". Zij benadrukten dat zij zich op een specifieke manier verhouden tot de toekomst door zich te positioneren als diegenen die in de toekomstverkenning uitspraken doen over "waarschijnlijke toekomsten". Zij zeiden het belangrijk te vinden "een bijdrage" te leveren aan "betrouwbare" en "wetenschappelijk onderbouwde" uitspraken over de toekomst (VVR Project Start Up, 2002). Dit zeiden zij te kunnen doen door "solide verbindingen" te maken "tussen de huidige situatie en de toekomst" en door zich daarbij te baseren op "empirische feiten" en "neutrale veronderstellingen". Eén van deze toekomstverkenners stelde "betrouwbaarheid suggereert kwantitatieve onderbouwing" en een ander gebruikte niet alleen de term "betrouwbaarheid", maar ook "overtuiging" om dit type uitspraken over de toekomst / dit type toekomstverkenning te kwalificeren. Daarmee leken zij wetenschappelijke betrouwbaarheid op één lijn te stellen met kwantificering en met prognoses in het bijzonder. Kwaliteit van de toekomstverkenning werd door hen beschreven in termen van wetenschappelijke betrouwbaarheid: het resultaat van consistente, onderbouwde, genuanceerde en gedetailleerde analyses. Zij zeiden tot slot hun resultaten vaak te presenteren in de vorm van "feiten", "woorden", "grafieken", "kaarten" en "tabellen" die aan een database en/of modellen gekoppeld zijn.

De andere groep toekomstverkenners positioneerde zichzelf als degenen die in de toekomstverkenning voor "verbeelding" en "creativiteit" zorgen door zich te richten op de vraag "wat betekent dit voor het beeld van Nederland". Zij zeiden inzicht te willen bieden in de "gewenste" en "mogelijke" situatie en voorstellingen te willen maken van "onverwachte" en nog "niet gekende toekomsten" en een bijdrage te willen leveren aan de toekomstverkenning door hun "creatieve" insteek. Zij karakteriseerden hun expertise met criteria als "oorspronkelijkheid", "fantasie", "inspirerend", "leuk" en "nieuw". Deze groep benadrukte dat in hun werk theorie een ondergeschikte rol speelt en dat zij daarom meer vrijheid hebben in het maken van keuzes. Zij zeiden in de presentatie van hun inzichten vaak te kiezen voor een "visuele vorm" zoals tweedimensionaal geografische kaarten of 3D visualisaties die niet direct terug te voeren zijn naar specifieke databases.

De eerste groep toekomstverkenners noemde zichzelf en werd door de andere groep aangeduid als "onderzoekers", de tweede als "ontwerpers". In het zichtbaar worden van 
deze twee culturen van toekomstverkennen in het WVR-project kreeg integratie daardoor nog een nieuwe betekenis, namelijk van interdisciplinariteit en in het bijzonder de integratie van onderzoek en ontwerp ${ }^{40}$.

De toekomstverkenners in de WR toekomstverkenning zeiden te streven naar "interdisciplinaire samenwerking" en een "interdisciplinair product". Uit het werkprogramma van het RPB blijkt overigens dat de integratie van onderzoek en ontwerp niet alleen een ambitie is van toekomstverkenners in het WR-project, maar van het planbureau in het algemeen. In het document 'Speerpunten van het Ruimtelijk Planbureau' lezen we bijvoorbeeld: "We willen komen tot een integratie van ontwerp en onderzoek, zowel binnen projecten (..) als binnen het planbureau als geheel (als een wijze van werken)". De motivatie achter het willen integreren van deze twee culturen van toekomstverkennen lijkt te schuilen in het idee dat wetenschappelijke analyses en modelberekeningen, hoe nauwkeurig en gedetailleerd zij ook zijn gemaakt, geen afspiegeling kunnen zijn van de toekomst en dat daarom een verkenning van de ruimte niet alleen op onderzoek worden gebaseerd. Anderzijds onderstrepen de toekomstverkenners het belang van wetenschappelijke (kwantitatieve) onderbouwing en suggereren zij dat een goede toekomstverkenning ook niet alleen op ontwerp gebaseerd kan zijn ${ }^{41}$.

De toekomstverkenners in het VR-project maakten zelf dus een onderscheid tussen twee culturen van toekomstverkennen. De ene cultuur vertegenwoordigt 'de wetenschap' en een meer rationele perspectief op de toekomst, de andere een meer intuitieve, creatieve perspectief ${ }^{42}$.

\footnotetext{
${ }^{40}$ Lattuca, Voight, \& Fath (2004) stellen dat interdisciplinariteit vaak wordt gedefinieerd als "the integration of existing disciplinary perspectives" (24-5).

${ }^{41}$ De ambitie onderzoeks- en ontwerpactiviteiten te integreren is niet nieuw. Al in 1948 benadrukte Van Lohuizen, een van de grondleggers van het planologisch onderzoek in Nederland, in zijn rede De eenheid van het stedebouwkundig werk het belang van samenwerking tussen onderzoekers en ontwerpers. Onderzoekers en ontwerpers moesten volgens van Lohuizen de "nauwst mogelijke samenwerking" nastreven, vanuit het idee dat "hoe meer ieder deel neemt in het werk van de ander en er van assimileert wat hij voor zijn taak nodig heeft, hoe sterker de eenheid van het werk zal groeien". Als meerwaarde van het combineren van beide tradities wordt een potentiële synergie tussen intuïtie en kennis verondersteld. Door ontwerpers bij onderzoek te betrekken wordt verwacht dat er meer aandacht ontstaat voor het intuitieve en de lokale context en "de veelkleurige werkelijkheid van het leven", terwijl onderzoekers juist kennis hebben over algemene trends en ontwikkelingen en hun onderlinge samenhang (van Lohuizen, 1948).

${ }^{42}$ Van Notten, Rotmans, van Asselt, \& Rothman (2003) maken hier het onderscheid tussen "formal" en "intuitive".
} 
'Integratie' is dus allesbehalve een constant begrip. Er zijn meerdere integratieambities en meerder insteken van integratie 'doen' (zie ook tabel 4.1).

\section{Integratieambities}

Integratie van subsystemen

--> holistisch perspectief
Betekenis (integratie $=$ )

'De som der delen'

'Meer dan de som der delen'

'Afstemmen'

'Optellen'

'Combineren'

'Interdisciplinariteit'
Betekenis (integratie van wat?)

Sectoren/thema's

Sectoren/thema's, schaalniveaus, disciplines

Aannames/veronderstellingen

Tijdshorizonnen, analyse-eenheden

Ruimteclaims

Kwantitatieve en kwalitatieve

inzichten

Onderzoek en ontwerp

Tabel 4.1-Verschillende integratieambities

In de WR praktijk van toekomstverkennen bleken verschillende integratie betekenissen naast elkaar te bestaan. Anders dan ik in het vorige hoofdstuk heb laten zien,

concurreren en conflicteren deze betekenissen niet met elkaar. Wel lijkt het zo te zijn dat sommige betekenissen vooral in de beginfase van de toekomstverkenning een rol spelen (zoals het afstemmen van aannames/veronderstellingen) en andere betekenissen juist in een latere fase manifest zijn (het optellen van ruimteclaims).

Gezien deze diversiteit aan integratiebetekenissen kunnen we stellen dat het beter is te spreken van integratieambities. En bovenstaande observaties suggereren dat er meerdere integratieambities naast elkaar kunnen bestaan in de praktijk van toekomstverkennen.

In de volgende paragraaf ga ik gedetailleerder kijken naar de manier waarop de toekomstverkenners in de VVR toekomstverkenning de hier boven beschreven integratieambities in de praktijk probeerden te realiseren. 


\subsection{Integratie van onderzoek en ontwerp}

De toekomstverkenners stelden dat, om te komen tot een "geïntegreerd product" twee verschillende culturen van toekomstverkenning moesten samenwerken, namelijk 'onderzoek' en 'ontwerp'. Samenwerking zeiden de toekomstverkenners te beschouwing als "belangrijk startpunt voor integratie" (Projectbijeenkomst WVR, 6 mei 2003). Als we willen begrijpen hoe de toekomstverkenners integratie 'doen', dan moeten we ons vizier dus in eerste instantie richten op de manier waarop zij (beogen te) samenwerken, verbindingen leggen en bruggen bouwen.

De manier waarop samenwerking, en daarmee integratie, tot stand zou kunnen komen visualiseerde de toekomstverkenners als volgt:

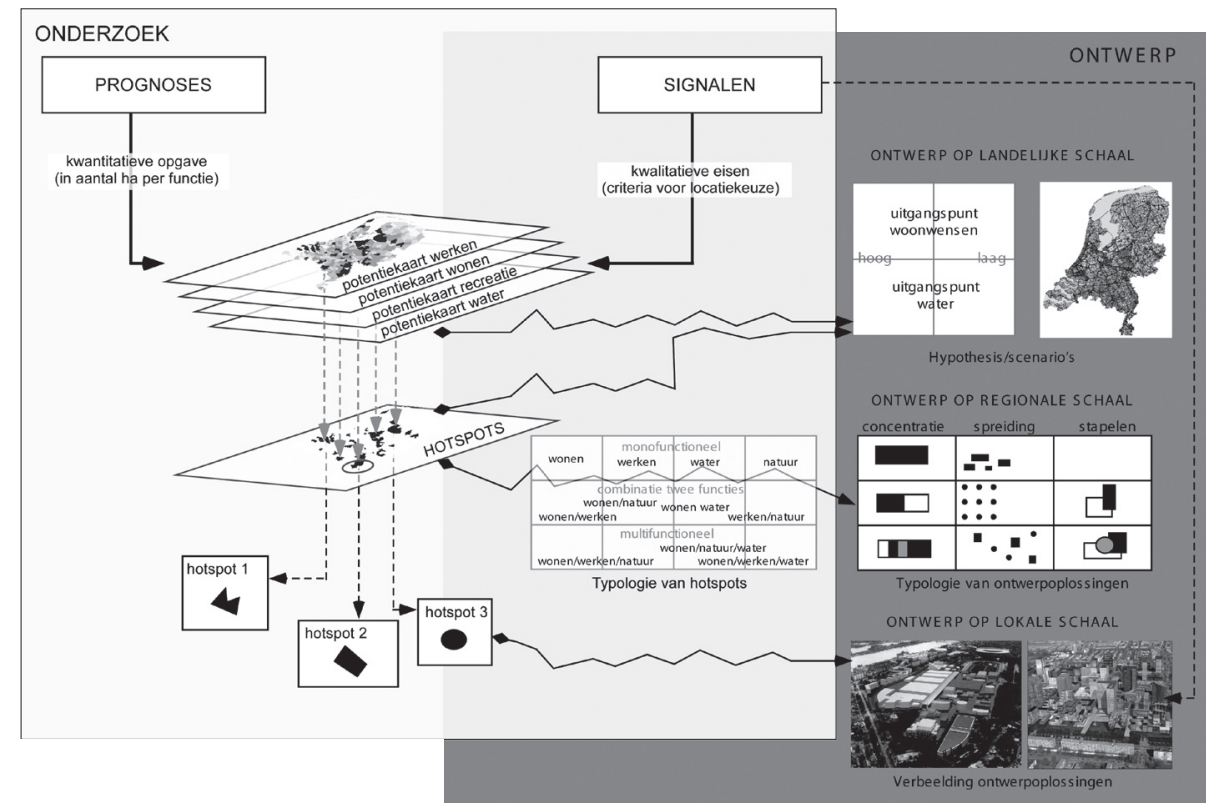

Fig. 4.2 Een plan voor intergratie van onderzoek en ontwerp

Het domein van de onderzoekers wordt in de figuur aangeduid met het linker vlak; het domein van de ontwerpers met het rechtervlak vlak. Gieryn (1995) gebruikt de term "social worlds" om verschillende groepen met "shared commitment to a common task" (412) aan te duiden. Klein (1996) geeft de volgende beschrijving: 
"A social world is simultaneously an organization of people, an identity, and a location. All social worlds share three properties: segmentation, legitimation, and intersection" (Klein 1996: 22).

Met segmentatie doelt zij op het naast elkaar bestaan van verschillende "subworlds". Legitimatie heeft betrekking op het definiëren en opleggen van standaarden en grenzen en "intersection" omschrijft zij als de in interactie tussen de verschillende sociale werelden. In de figuur zien we dat de toekomstverkenners de twee domeinen deels laten overlappen. Zo'n 'intersection' tussen twee disciplinaire domeinen kan ook worden aangeduid met termen als "overlapping territory", "border zone" (Klein, 1996), "borderland" (Martinez, 1994), "interfield" (Maasen, 2000), "zone of interdependence" (Parsons, 1970), "trading zone" (Galison, 1999) en "translation terrain" (Brosveet, 2004). De toekomstverkenners in het WR-project beschrijven de 'intersection', dat ik vanaf nu zal duiden met de term 'grensgebied', als de plek waar samenwerking tussen onderzoekers en ontwerpers moest gaan plaatsvinden. Volgens de "boundary theory" 43 , zoals dat is ontwikkeld in het zogenaamde 'Science, Technology and Society' (STS) programma, is dat de plek waar grensverkeer plaatsvindt en, met andere woorden, grenzen worden getrokken en bruggen (kunnen) worden gebouwd tussen verschillende disciplinaire culturen. Bal, Bijker, \& Hendriks (2002) karakteriseren dit proces bijvoorbeeld als een "georkestreerde mix van begrenzen en overbruggen" (189) en "een omvattend proces van verbindingen leggen en grenzen trekken" (311). Integratie in de vorm van interdisciplinariteit behelst dus het overbruggen van disciplinaire verschillen en verbindingen leggen.

Het integratieplan werd omarmd door zowel onderzoekers als ontwerpers en is dus tevens op te vatten als een soort "samenwerkingsverdrag" tussen de twee culturen van toekomstverkennen, waarin ook een samenwerkingsgebied (een grensgebied) wordt gelokaliseerd.

\section{Integratie door samenwerking}

In het 'grensgebied' van de domeinen onderzoek en ontwerp positioneerden de toekomstverkenners een aantal activiteiten, waaronder het maken van "potentiekaarten", en "signalen" (zie 'integratieplan'). Deze activiteiten verschenen voor het eerst ten tonele als één van de resultaten die het projectteam in het projectcontract beloofde op te leveren. Deze grensgebiedactiviteiten waren dus al eerder in 'embryonaal stadium'

\footnotetext{
43 "Boundary theory" is geen algemeen gehanteerde term, maar ik denk dat de tijd rijp is om het geheel aan literatuur over de rol van grenzenwerk in kennisconstructie zo aan te duiden (Star, 1989); (Star \& Griesemer, 1989); (Gieryn, 1995); (Hilgartner, 2000); (Bal, Bijker, \& Hendriks, 2002); (Halffman, 2003).
} 
aanwezig. Ongeveer een half jaar na de start van het project, werden zij echter expliciet gepositioneerd in het grensgebied van onderzoek en ontwerp. Daarmee zagen de toekomstverkenners de potentiekaarten en signalen dus niet alleen als een resultaat van integratie, of als randvoorwaarde voor het kunnen samenwerken (= integreren), maar ook als manier van samenwerken.

Ik ben niet de eerste die interdisciplinaire samenwerking in kennisproductie bestudeert. Sinds eind jaren 80 van de vorige eeuw verschenen er in de wetenschapssociologie verschillende studies waarin de collectieve constructie van kennis door leden van verschillende sociale werelden werd bestudeerd. Onder anderen Callon (1986), Latour (1987; 1999), Star \& Griesemer (1989) en Clarke \& Fujimura (1992) hebben laten zien dat samenwerking tussen verschillende disciplinaire werelden niet vanzelf gaat. Zo beschrijven Star \& Griesemer (1989) in hun publicatie "Institutional Ecology, 'Translations' and Boundary Objects" hoe amateur-naturalisten, professionele biologen en andere betrokkenen (zoals filantropen, conservatoren en preparateurs) in de beginperiode van het Zoölogisch Museum in Berkeley manieren vinden om samen te werken in het verzamelen en conserveren van gewervelde diersoorten. Latour (1999) observeerde een veldexpeditie van een botanist, een pedoloog en een geograaf die antwoord zoeken op de vraag of de omvang van het Boa Vista bos, een deel van het Amazone regenwoud, afneemt of juist toeneemt. Auteurs als deze laten zien dat samenwerking en de daadwerkelijke constructie van gedeelde kennis wordt voorafgegaan door een complex en langdurig proces van "negotiation, articulation, translation, triangulation, debating, and sometimes even coercion" (Fujimura, 1992: 171). Met andere woorden, om te kunnen samenwerken moet het grensgebied een "common ground" (Beers, 2005) worden in plaats van een niemandsland of een 'no go area'.

Deze auteurs hebben laten zien dat mensen, hoewel zij verschillende analyse-eenheden, methoden en abstracties gebruiken en zonder dat zij een compleet beeld en begrip hebben van elkaars werk, uiteindelijk wel kunnen samenwerken. Het is dus niet tot mislukken gedoemd. Hoe maken mensen vanuit verschillende sociale werelden van een grensgebied een 'common ground'? Star \& Griesemer (1989) verklaren dit aan de hand van het concept "boundary objects" 4 . Dit zijn ideeën, woorden, objecten (documenten,

\footnotetext{
${ }^{44}$ Latour (1987) gebruikte de term "immutable mobiles" die hij omschreef als "things that can travel without withering away (are mobile), that do not fundamentally alter on the trip (are immutable), that can be provided to and interpreted by others (are presentable and readable), and that can be linked to other things (are combinable) (7). Als voorbeeld noemde hij kaarten, die, hoewel op het moment dat zij worden toegepast op nieuwe visuele contexten, optisch consistent blijven. Een belangrijke eigenschap van deze "immutable mobiles" is daarom, volgens Latour, dat zij stabiel lijken. Latour's opvatting van reizende objecten geeft inzicht in de vraag waarom bepaalde objecten, woorden en technieken zowel in de ene als de andere wetenschappelijke context kunnen overleven. Star \& Griesemer (1989) bouwden voort op dit idee en beschouwden 'immutable mobiles' als
} 
concepten, technieken) en processen die algemeen genoeg zijn dat zij verschillende sociale werelden kunnen doorkruisen en toch specifiek genoeg zijn dat zij, ondanks de verscheidenheid tussen die werelden, in de lokale, individuele behoeftes kunnen voorzien:
"Boundary objects are objects which are both plastic enough to adapt to local needs and the constraints of the several parties employing them, yet robust enough to maintain a common identity across sites. They are weakly structured in common use, and become strongly structured in individual-site use. They can have different meanings in different social worlds, but their structure is common enough to more than one world to make them recognizable, a means of translation" (Star \& Griesemer, 1989: 393).

Door deze eigenschappen kunnen deze grensobjecten relatief eenvoudig van de ene context naar de andere reizen (Star, 1989); (Star \& Griesemer, 1989); (Nowotny, Scott, \& Gibbons, 2001) en als het ware een infrastructuur bieden waardoor grensverkeer plaats kan vinden en samenwerking mogelijk wordt. Ik wil dit "boundary object"concept inzetten om te beschrijven hoe de toekomstverkenners twee culturen van toekomstverkennen proberen te integreren en om te begrijpen waarom dat wel of niet lukt. Ik introduceer hier dus $2^{\mathrm{e}}$ orde vocabulaire om mijn observaties betekenis te kunnen geven. Omdat grensobjecten het grensgebied tussen verschillende sociale werelden kunnen doorkruizen en overschrijden en daarmee als het ware een web spinnen waarlangs samenwerking kan plaatsvinden spreek ik liever van grensoverschrijdende objecten dan van grensobjecten.

Een logische volgende stap is dus om "potentiekaarten" en "signalen", die worden gepositioneerd op het grensgebied tussen de twee domeinen te beschouwen als potentieel grensoverschrijdende objecten en te analyseren hoe de toekomstverkenners deze vorm proberen te geven in het proces van samenwerking. Om te begrijpen hoe verschillende culturen van toekomstverkennen samenwerken, moeten we dus niet alleen kijken naar de productie van grensobjecten zelf, maar ook naar de manier waarop deze worden gemobiliseerd en zelf een rol gaan spelen in de samenwerking tussen en uiteindelijk integratie van onderzoek en ontwerp. Om te begrijpen welke rol deze potentied grensoverschrijdende objecten spelen in het integratieproces zal ik in het volgende deel beschrijven en analyseren hoe de toekomstverkenners de twee potentiële grensoverschrijdende objecten "signalen" en "potentiekaarten" probeerden te construeren. 


\section{Samen werken aan potentiële grensoverschrijdende objecten}

De toekomstverkenners beschouwden het tot stand komen van "potentiekaarten" en "signalen" als "een gezamenlijke verantwoordelijkheid" van zowel onderzoekers als ontwerpers en ze stelden daarom voor er "samen" en "in een open discussie met elkaar" aan te werken. Een van hen stelde: "We moeten het met zijn allen gaan doen". Onderzoek en ontwerp werden door de toekomstverkenners neergezet als twee gelijkwaardige partners. Achter het samenwerkingsverdrag tussen onderzoekers en ontwerpers schuilt dus als het ware een egalitair perspectief op integratie.

De toekomstverkenners kozen niet voor het doorlopen van een min of meer gestandaardiseerd stappenplan, maar voor een open, creatief en ongestructureerd proces van samenwerking. Dus zonder een van tevoren opgesteld plan in de vorm van een script of een draaiboek of een duidelijke beschrijving van wat de samenwerking uiteindelijk op zou moeten leveren. De bijeenkomsten leken alleen gestuurd te worden door een aantal breed geformuleerde vragen. Zo werden tijdens het project verschillende brainstorm-achtige sessies georganiseerd, waaraan zowel onderzoekers als ontwerpers deelnamen. Deze open en creatieve sessies waren soms meer methodologisch van aard ("hoe kunnen we onderzoeksresultaten vertalen naar criteria voor ontwerp?") en soms meer inhoudelijk, zoals wanneer de toekomstverkenners werken aan een specifiek thema ("wat is 'herstructurering' en hoe kunnen we dit thema meenemen in de toekomstverkenning?").

\section{Samen werken aan "potentiekaarten"}

Het grensoverschrijdende object "potentiekaarten" karakteriseerden de toekomstverkenners al eerder in het project als "ruimtelijke vertalingen" van de sectorale prognoses op een kaart van Nederland (zie paragraaf 4.1). De onderzoekers zetten voor het maken van de potentiekaarten de eerste stap door te bepalen welke inzichten er aan de kwantitatieve analyses ontleend konden worden over de aantrekkelijkheid en onaantrekkelijkheid van gebieden (gemeenten, regio's, provincies) in Nederland. Voor het thema Wonen identificeerde de betrokken onderzoeker bijvoorbeeld vier mogelijke potentiekaarten, namelijk potentie voor groei van de economische sectoren: industrie, handel/distributie, zakelijke diensten en overige diensten. Binnen het thema Wonen was het de bedoeling te kijken naar waar in Nederland meer of minder potentie is voor het creëren van (nieuwe) of het herinrichten van (oude) woonmilieus ${ }^{45}$. Voor Water

\footnotetext{
${ }^{45}$ De toekomstverkenners maakten een onderscheid tussen dertien verschillende woonmilieus, namelijk: centrum stedelijk plus, centrum stedelijk, stedelijk vooroorlogs, stedelijk naoorlogse compact, stedelijk naoorlogse grondgebonden, groen stedelijk, centrum kleinstedelijk, kleinstedelijk, groen kleinstedelijk, centrum dorps, dorps, landelijk bereikbaar en landelijk perifeer.
} 
werden de potenties voor veiligheid en het vasthouden/bergen van water verkend. Hoe verliep de samenwerking tussen onderzoekers en ontwerpers in het tot stand komen van deze potentiële grensoverschrijdende objecten? Daartoe beschrijf ik in detail het constructieproces van de potentiekaarten voor het thema Wonen.

Nadat de kwantitatieve analyses (prognoses) voor het thema Wonen nagenoeg waren afgerond, spraken de onderzoekers met de ontwerpers over de volgende te nemen stap in de toekomstverkenning, namelijk het maken van de "potentiekaarten". Tijdens deze bijeenkomsten lieten de onderzoekers weten dat het onderzoek in hun ogen onvoldoende gegevens had opgeleverd om goed onderbouwde potentiekaarten te maken. Volgens de onderzoekers waren de criteria die bepalen waar een bepaald woonmilieu in de toekomst zou kunnen ontstaan "onvoldoende specifiek". De kwantitatieve analyses die zij gemaakt hadden gaven volgens één van de onderzoekers geen inzicht in de vraag waar de toekomstige ruimtevraag die zij heeft berekend "ruimtelijk neerslaat". Een van hen legde uit:

\begin{abstract}
"Ik heb bijvoorbeeld berekend dat in Flevoland een groei komt van het aantal mensen dat centrum stedelijk wil wonen. Maar dan weet ik nog niet waar in Flevoland de meeste potentie is voor centrum stedelijk wonen. Nu kun je dat uit je duim zuigen en zeggen 'Dat zal wel in Almere en Lelystad zijn', maar waar is dat dan op gebaseerd? Dat kan je toch niet zomaar op de kaart zetten zonder onderbouwing?" (Projectbijeenkomst VVR, 7 april 2003).
\end{abstract}

Volgens de onderzoekers was het niet mogelijk om goed onderbouwde kaarten te maken voor dit thema en zou je "hele nieuwe analyses" moeten doen waar zij bovendien geen tijd meer voor hadden. Deze onderzoekers trokken het maken van de kaarten enerzijds in het domein van de onderzoekers, maar constateren tegelijkertijd dat de kaarten niet aan de onderzoekscriteria kunnen voldoen en ze geen tijd hadden om het te doen.

Toen één van de toekomstverkenners erop wees dat het tot stand komen van de potentiekaarten niet alleen haar verantwoordelijkheid was, maar "een gezamenlijke verantwoordelijkheid" van zowel onderzoekers als ontwerpers reageerde ze met:

"Je kunt wel een ochtend bij elkaar gaan zitten en die kaarten gaan maken, maar waar is dat dan op gebaseerd? Is dat expert opinion, of heb je daar dan ook literatuur bij. Dadelijk heb je een lijst met criteria waarvan je denkt 'Die zullen wel belangrijk zijn', maar je weet het niet. Je kunt elk woonmilieu overal ontwerpen. Zo kun je in een weiland zelfs een centrum stedelijk woonmilieu creëren" (Projectbijeenkomst VVR, 10 april 2003).

Volgens deze onderzoeker gaf het onderzoek, zoals zij dat had gedaan, "onvoldoende richtlijnen" voor het maken van de potentiekaarten en zij zei daarbij geen genoegen 
te willen nemen met kaarten die in haar ogen zijn gemaakt op basis van wat zij noemde "arbitraire (lees: niet systematisch onderbouwde, sk) keuzes". De ontwerpers reageerden daarop door het maken van de kaarten juist naar het domein van de ontwerpers te trekken. Eén van de ontwerpers wees de onderzoeker erop dat zij het probleem "nu te ingewikkeld" maakt en zei zelfs dat er volgens hem eigenlijk helemaal geen probleem was. Want, zei hij, "dan doen we het toch ontwerpend?". Hij legde uit dat ontwerpers ook zonder uitgebreide wetenschappelijke onderbouwing kaarten kunnen maken, maar "zonder dat het ontwerp arbitrair wordt". Na een lange discussie tussen onderzoekers en ontwerpers werd een impasse voorkomen door te besluiten de potentiekaarten die niet aan de criteria van de onderzoekers voldeden te herdefiniëren en te positioneren als "ontwerpkaarten" in plaats van "potentiekaarten". Beide partijen beaamden zich in deze oplossing te kunnen vinden en de projectleider constateerde vervolgens: "Je verantwoording is dan dus van een andere orde" (Projectbijeenkomst VVR, 10 april 2003). Er werd dus overeenstemming bereikt door het maken van de potentiekaarten uit het grensgebied te trekken. Doordat de toekomstverkenners een sterke grens trokken tussen de domeinen onderzoek en ontwerp en de potentiekaarten te labellen als ófwel een ontwerpactiviteit (de kaarten voor het thema Wonen) óf onderzoeksactiviteit (de kaarten voor het thema Werken) werd enerzijds een echte impasse voorkomen, maar anderzijds was er geen infrastructuur voor samenwerking.

De discussies rondom de potentiekaarten voor de thema's Werken en Water vonden zo goed als buiten mijn gezichtsveld plaats (zie ook hoofdstuk 2). Wel was zichtbaar dat deze potentiekaarten in de loop van de verkenning ook werden verplaatst uit het grensgebied en wel naar het domein van de onderzoekers. Dus, hoewel deze potentiekaarten vooraf werden gepositioneerd op het grensgebied tussen de domeinen onderzoek en ontwerp (en daarmee als gedeelde verantwoordelijkheid van onderzoekers en ontwerpers) bleek in de praktijk dat zij opnieuw werden gepositioneerd als onderzoeksactiviteit. Daarmee waren de potentiekaarten dus geen grensoverschrijdende objecten meer als product van en middel in de samenwerking tussen onderzoekers en ontwerpers.

\section{Samen werken aan "signalen"}

Om tot komen tot een uitwerking van "signalen" (zie paragraaf 4.1) besloten de toekomstverkenners verschillende bijeenkomsten te organiseren. Deze bijeenkomsten kregen de naam "ontwerpworkshops" en werden georganiseerd door de sectordeskundigen (Wonen, Werken, Water) en de ontwerpers en bijgewoond door vijf tot tien onderzoekers en ontwerpers van binnen en buiten het projectteam. Tijdens deze bijeenkomsten dachten zij gezamenlijk na over vragen als 'Onder welke voorwaarden zou de ontwikkeling (= signaal, sk) zich kunnen voordoen?', 'Waar zou het zich kunnen voordoen en met welke intensiteit?' en 'Wat zou de kwalitatieve en/of kwantitatieve 
impact op de ruimte kunnen zijn?'.

Uit de grote betrokkenheid van zowel onderzoekers als ontwerpers blijkt dat de toekomstverkenners deze bijeenkomsten beschouwden als een belangrijk forum waar afstemming tussen onderzoeks- en ontwerpexpertise zou kunnen plaatsvinden. Dus ondanks het label 'ontwerp' ervaarden de toekomstverkenners het maken van de signalen wel als een activiteit in het grensgebied:

Op een tafel liggen allerlei teksten, foto's, grafieken en kaarten en aan de muur hangen beschreven flip-overs. Eén van de ontwerpers, die een week eerder een herstructureringsgebied in Utrecht heeft bezocht, laat haar foto's zien en legt uit waarom de afbeeldingen op de foto's zo kenmerkend zijn voor een herstructureringsgebied. Terwijl ze de foto's een voor een laat zien maakt ze opmerkingen als: "Herstructureringsgebieden zijn goed ontsloten", "hebben ruimte", "volwassen groen", "sportvelden" en "veel hoogbouw". Haar boodschap is dat herstructureringsgebieden veel mogelijkheden bieden en dat die mogelijkheden beter zouden kunnen worden benut. Na deze fotosessie raakt een paar mensen in discussie met een deskundige van buiten het projectteam op het gebied van herstructurering en denkt na over mogelijke kenmerken van toekomstige herstructureringsgebieden. Er wordt aandachtig geluisterd en kritische vragen gesteld. Anderen zitten samen achter een computer om te werken aan een uitgebreide inhoudsopgave voor het verhaal dat zij willen vertellen. Mensen zijn enthousiast en lijken het gevoel te hebben dat ze nuttig werk verrichten. Eén van de onderzoekers constateert ook zelf dat zij "hard werken" en een ontwerper zegt tevreden dat er "een duidelijke lijn" is uitgezet. Weer een ander heeft het idee dat er "consensus" is en dat "iedereen is het eens met deze lijn" (Projectbijeenkomst VVR, 25 februari 2003).

Voor de uitwerking van het signaal 'Herstructurering'46 werden tijdens de verkenning zogenaamde "ontwerpworkshops" georganiseerd. Tijdens de grensgebiedworkshops vroegen de toekomstverkenners zichzelf af of herstructurering "wel een goede methode" was voor gemeentes om tegemoet te komen aan de "veranderende woonwensen in de stad" en of het wel verstandig was om herstructureringsgebieden te gebruiken "om aan de woonwensen van de toekomst te voldoen". Dus, in plaats van de mogelijke impact te verkennen gingen de toekomstverkenners in discussie over normatieve vragen.

\footnotetext{
${ }^{46}$ Uit de discussies maakte ik op dat het concept 'Herstructurering' voor het eerst werd gelanceerd in de Nota Wonen van het Ministerie van VROM en daarin naar voren werd gebracht als een manier om "bestaand gebouwd gebied" beter te benutten met als doel om de kloof te dichten tussen vraag en aanbod van woningen. Door deze wijken te "transformeren" proberen gemeentes zogenaamde "scheefgroei" tussen vraag en aanbod van woningen min of meer recht te trekken. De toekomstverkenners duidden herstructureringsgebieden aan als verouderde wijken waarin door gemeenten grootschalig wordt ingegrepen, omdat de ruimte niet meer voldoet aan de kwaliteitseisen en woonwensen van mensen (VROM, 2000).
} 
De signalen lijken, in tegenstelling tot de potentiekaarten, te kunnen functioneren als grensoverschrijdende objecten tussen de domeinen onderzoek en ontwerp. Daarmee dragen ze bij te dragen aan het creëren van een 'common ground' tussen beide culturen van toekomstverkennen en faciliteren samenwerking. Echter, ondanks de betrokkenheid van de onderzoekers en ontwerpers en het enthousiaste en harde werken tijdens de ontwerpworkshops zelf waren de toekomstverkenners ontevreden over het resultaat. Tijdens een bijeenkomst van het projectteam uitte één van de ontwerpers zijn zorgen over de voortgang. Hij heeft geconstateerd dat vanaf het moment dat de mensen na de workshops uit elkaar gaan "de lijn uiteenfladdert en verbreedt" en dat zowel onderzoekers als ontwerpers uiteindelijk "met een heel ander verhaal" bezig zijn. De toekomstverkenners zelf constateerden:

"Of er gebeurt niets, of in de wandelgangen ontstaat een nieuw verhaal, dus het verbreedt heel erg, dus de lijn versplintert weer, omdat mensen toch hun eigen verhaal er weer in willen hebben" (Projectbijeenkomst VVR, 18 augustus 2003).

De signalen als potentieel grensobject zijn dus te "plastisch" en niet voldoende "robuust" om een gedeelde identiteit of 'common ground' te kunnen vormen tussen de twee culturen van toekomstverkennen, hetgeen noodzakelijk is om de werelden van de onderzoekers en de ontwerpers te kunnen verbinden (want, zoals ik eerder heb laten zien, verwijzend naar Star \& Griesemer (1989): "Boundary objects are objects which are both plastic enough to adapt to local needs and the constraints of the several parties employing them, yet robust enough to maintain a common identity across sites").

Sommige toekomstverkenners karakteriseerden de bijeenkomsten achteraf als "zeer vermoeiend en niet echt productief". De projectleider, die probeerde te begrijpen wat er aan de hand was, constateerde: "Dus wat je dan terug ziet is, of iets anders, of niets". Dit werd beaamd door de verantwoordelijke onderzoeker die zei: "Dat is ook mijn verhaal". De organisatoren schrijven het verbreden en versplinteren van de verhaallijn toe aan het gebrek aan verantwoordelijkheid en discipline. Eén van de ontwerpers zei bijvoorbeeld: "Mensen laten het liggen, voelen zich niet verantwoordelijk" voor het gezamenlijke product. De eerder optredende onderzoeker zei hierover verrast te zijn "omdat we toch dingen vastleggen aan het eind, dus dat je het niet open laat". De ontwerper beaamde dit een zei: "We maken duidelijke productafspraken. Van dit en dit moet geproduceerd worden". De organisatoren begrepen niet waarom het dan toch niet lukt om de verhaallijn overeind te houden als de groep na de workshops uit elkaar gaat. De onderzoeker uitte haar onbegrip door te stellen:

"Gisteren hebben we het op flappen gezet, dus dat je wel houvast hebt. Dat er achteraf niet wordt gezegd, ja maar er is ook dit gezegd en dat gezegd. Je hebt wel iets vastgelegd aan het eind, iedereen is het ermee eens en het wordt die boodschap en dan vervolgens....". (Projectbijeenkomst WVR, 18 augustus 2003).

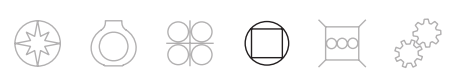


Zelf schreven de toekomstverkenners het falen van de signalen toe aan een gebrek aan verantwoordelijkheid. Mijn verklaring daarentegen is dat de signalen als potentieel grensoverschrijdend object dus niet robuust genoeg zijn om ook buiten de context van de workshops, dus in de domeinen onderzoek en ontwerp, te overleven. Eenmaal in het domein van de onderzoekers en de ontwerpers verliezen de signalen en de gemaakte afspraken hun kracht: vanuit het perspectief van de onderzoekers waren de signalen onvoldoende systematisch onderbouwd en vanuit het ontwerpperspectief onvoldoende vernieuwend en aansprekend. Dat het niet lukte de signalen te laten overleven in de domeinen onderzoek en ontwerp, is ook de ervaring van één van de onderzoekers. Zij stelde voor om "in groepsverband" te blijven werken, dus op het grensgebied tussen onderzoek en ontwerp en mensen niet langer "met productafspraken weg te sturen". Zij was van mening dat je "samen moet doorgaan" binnen de context van de ontwerpworkshops om het werk goed te kunnen blijven afstemmen en om tot producten te kunnen komen. Deze toekomstverkenner stelde dus voor om de signalen uit de domeinen onderzoek en ontwerp terug te halen en ze weer nadrukkelijk in het grensgebied te ontwikkelen.

Ondanks de pogingen het grensgebied te versterken of het potentiële grensobject te beschermen (onder andere door het te herpositioneren als gezamenlijke verantwoordelijkheid), lukte het de verkenners niet om resultaten te leveren die, in de ogen van zowel onderzoekers als ontwerpers, voldeden aan hun kwaliteitseisen. De toekomstverkenners besloten daarom de signalen die zij niet konden laten voldoen aan de kwaliteitscriteria van zowel onderzoekers als ontwerpers uit de verkenning te schrijven en geen plek meer te geven in de uiteindelijke publicatie. De meest veelbelovende signalen herpositioneerden de toekomstverkenners als onderzoeksproduct. Dus net als wat we bij de potentiekaarten zagen gebeuren, verplaatsten de toekomstverkenners ook deze potentiële grensoverschrijdende objecten uit het grensgebied naar het domein van de onderzoekers of de ontwerpers. 


\subsection{Het integratieplan wordt herschreven}

De toekomstverkenners slaagden er dus niet in een 'common ground' te creëren en door het middel van grensoverschrijdende objecten een brug te slaan tussen de domeinen onderzoek en ontwerp. De consequentie hiervan was dat er gedurende de toekomstverkenning verschillende grensconflicten, bijvoorbeeld over het bepalen van kwaliteitscriteria en het toekennen van verantwoordelijkheden, bleven bestaan. De activiteiten die voorheen waren gedefinieerd als "gezamenlijke verantwoordelijkheid" werden uiteindelijk scherp afgebakend en gepositioneerd in het ene of het andere domein. Zo plaatsten de toekomstverkenners de potentiekaarten voor het thema Werken in het domein van de onderzoekers en die van Wonen in het domein van de ontwerpers. Ook de signalen werden weggehaald uit het grensgebied. Met andere woorden, de potentiële grensoverschrijdende objecten overleefden niet, maar werden als het ware een 'domeinsobject'. Dit had als (onbewust en onbedoeld) effect dat het grensverkeer tussen beide domeinen afnam en een steeds scherpere grens werd getrokken tussen beide domeinen en waardoor het grensgebied - waar samenwerking tussen de twee culturen van toekomstverkennen had moeten plaatsvinden - vervaagde. Er ontstond dus als het ware een nieuw, maar klassiek twee-culturenmodel, waarin de domeinen onderzoek en ontwerp sterk werden gedemarkeerd. Dit nieuwe model zou dan als volgt kunnen worden weergegeven:

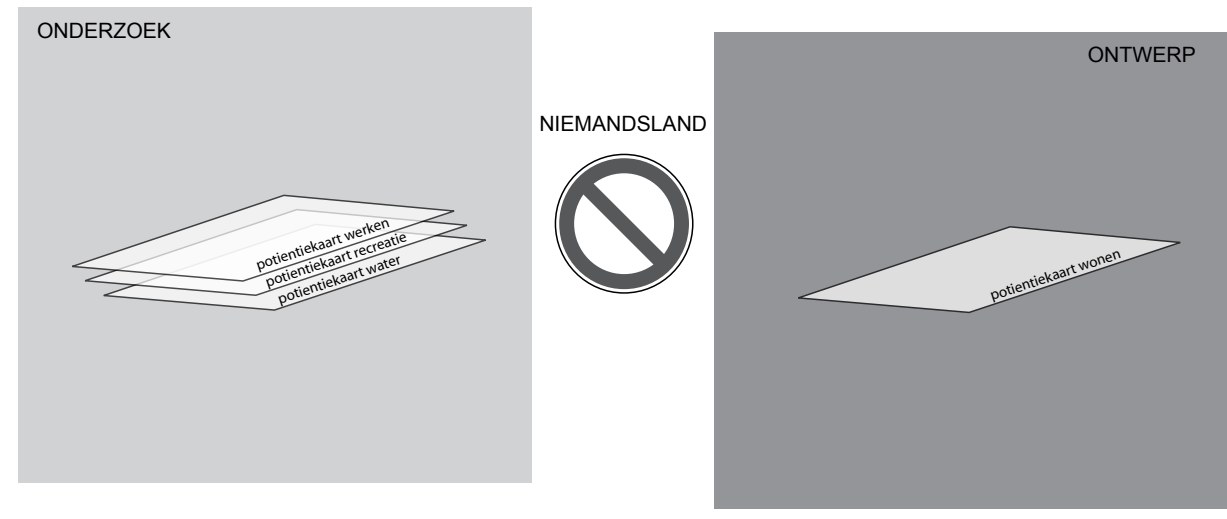

Fig. 4.3 - Het integratieplan herschreven (mijn kaart, niet die van de toekomstverkenners zelf).

Door het verdwijnen van het grensgebied ontstond er een barrière voor samenwerking tussen onderzoekers en ontwerpers en daarmee een barrière voor integratie. Van den Berg \& van Houtum (2003) beschrijven deze situaties waarin een grens een barrière gaat vormen voor grensoverschrijdende activiteiten in termen van afname van de 'permeability'. De herdefinitie van grenzen leidde in de WR-toekomstverkenning 
uiteindelijk tot een sterke afname van het grensverkeer. En doordat er geen grensobjecten werden gemaakt ontstond er geen infrastructuur en verdween uiteindelijk het grensgebied en kwam er als het ware een niemandsland voor in de plaats.

In het boek Border People (1994) van Martinez worden vier verschillende modellen van grenzenwerk onderscheiden en beschreven, namelijk "alienated borderlands", "coexistent borderlands", "interdependent borderlands" en "integrated borderlands" $(6-7)^{47}$. Elk model illustreert als het ware een bepaalde mate van grensverkeer tussen "bewoners" van verschillende "landen". Aan de ene kant van het spectrum staat het vervreemdingsmodel, waarin de grens min of meer gesloten is en er nauwelijks sprake is van grensverkeer. In dit model leven de bewoners van beide landen als vreemdelingen naast elkaar. Aan de andere kant van het spectrum staat het integratiemodel, waar de grens tussen beide landen open is en er sprake is van ongelimiteerde ruimte voor grensverkeer tussen beide landen. In het VVR-project zien we dat het 'integratiemodel' gezien werd als ideaal, maar dat in de praktijk onderzoekers en ontwerpers zich steeds meer van elkaar gingen vervreemden en zich dus, gedurende het verkenningsproces, steeds meer bewogen richting het 'vervreemdingsmodel'. Door het opnieuw positioneren van de potentiële grensoverschrijdende objecten transformeerde het samenwerkingsmodel dus beetje bij beetje richting het vervreemdingsmodel. Onderzoekers en ontwerpers slaagden er niet in om in het grensgebied grensobjecten te produceren waarmee een infrastructuur kon worden gebouwd die het mogelijk zou maken beide territoria te doorkruizen. Het grensgebied werd geen 'common ground', maar een niemandsland en daarmee een barrière in plaats van een basis voor samenwerking.

De toekomstverkenners zelf zeiden over het ontbreken van wat zij een "gezamenlijke basis" noemen:

"Als je geen gezamenlijke basis hebt, dan blijf je langs elkaar heen praten, dan raak je elkaar steeds weer kwijt. We hebben een gezamenlijk startpunt nodig van waaruit we kunnen gaan werken. We hebben al heel lang geconstateerd dat de grote lijn ontbreekt, waardoor we door ongelooflijke willekeur en onvoorspelbaarheid worden voort gestuurd. Het project blijft een grote zoektocht" (Projectbijeenkomst VVR, 25 augustus 2003).

Steeds als het projectteam geen overeenstemming bereikte over de manier waarop het grensverkeer tussen onderzoek en ontwerp gecoördineerd kon worden, werd de afspraak over gezamenlijke verantwoordelijkheden weer opengebroken en werden de verantwoordelijkheden òf gepositioneerd in het domein van de onderzoekers òf van de ontwerpers. Gedurende het project ontstond dus als het ware een nieuwe taakverdeling:

${ }^{47}$ Dit is geen STS publicatie, maar een sociologische studie naar geografische landengrenzen (en in het bijzonder die tussen Mexico en de Verenigde Staten). 
andere vormen van coördinatie en demarcatie tussen beide domeinen en nieuwe patronen waarin de verantwoordelijkheden en problemen in het verkennen van de toekomst opnieuw werden verdeeld tussen onderzoekers en ontwerpers.

Het sneuvelen van de potentiële grensoverschrijdende objecten lijkt te voorspellen dat de integratieambitie(s), ondanks de 'goede' start (namelijk het suggereren van potentiële grensobjecten, het lokaliseren van een grensgebied en deels daarmee het voorstellen van activiteiten in het grensgebied tussen de twee domeinen), tot mislukken is gedoemd. En dat blijkt ook uit vervolg van het verhaal...

\subsection{Ontwerp sneuvelt}

Wat betekent het sneuvelen van de potentiële grensoverschrijdende objecten en het ontstaan van een andere sociale orde met nieuwe structuren voor het verdere verloop van de toekomstverkenning en de realisatie van de integratieambities die de toekomstverkenners zichzelf hadden gesteld? Observaties uit de praktijk laten zien dat de ene niet te nemen horde (het organiseren van grensverkeer tussen beide domeinen) een obstakel wordt voor de volgende horde, namelijk het maken van ontwerpen. Hoe gebeurde dit? Hoe raakte het ontwerp in het geding?

Tegen het einde van het project realiseerden de toekomstverkenners zich dat de samenwerking tussen onderzoekers en ontwerpers andere producten had opgeleverd dan in het oorspronkelijke samenwerkingsverdrag werd voorzien. Sommige resultaten beschouwen zij als "te weinig specifiek" en andere inzichten hadden in hun ogen juist "te veel detailniveau". Daarbij gaven zij aan moeite te hebben met de "ongelijksoortigheid" van de onderzoeksdata en het betrekken van "goede en betrouwbare gegevens uit het onderzoek". Een van hen stelde: "De kaarten zijn zo verschillend. Hierdoor zijn wij appels met peren aan het vergelijken" (Projectbijeenkomst VVR, 12 mei 2003). Met name de onderzoekers leken moeite te hebben met het gebruiken van de inzichten uit de verschillende sectorale studies voor het maken van ontwerpen. Zo zag ik één van de onderzoekers geconcentreerd naar zijn computerscherm kijken. Hij had verschillende documenten openstaan en toen ik ernaar vroeg legde hij mij uit dat het de verschillende prognosetabellen en potentiekaarten waren die zij hadden gemaakt. Toen hij verschillende keren heen en weer had geklikt tussen document met tabellen en kaarten stelde hij zichzelf hardop de vraag: "Hoe weet je nu of dit gebied in de toekomst nu bestemd zal zijn voor natuur, landbouw of woningbouw?". Hij gaf daarbij aan het ontwerpen van de toekomstige kaart van Nederland "nogal willekeurig" te vinden, omdat het onderzoek volgens hem onvoldoende inzichten had opgeleverd om systematisch de toekomstige ruimtevraag door middel van ontwerpen te kunnen verbeelden. De ontwerpers probeerden de onderzoekers echter aan te sporen niet te veel bij het

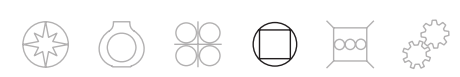


probleem van willekeur stil te blijven staan. Eén van de ontwerpers stelde daarom dat je

"nooit echt kunt weten hoe de toekomst eruit ziet. Je kunt nooit iets 100\% nauwkeurig berekenen. Je kunt de realiteit alleen proberen te benaderen" (Projectbijeenkomst VR, 12 mei 2003).

en maande daarmee de onderzoekers te accepteren dat er soms arbitraire keuzes gemaakt moeten worden om te komen tot ontwerpen. Na dit geconstateerd te hebben stelde ze dat ze maar "moeten werken met wat we hebben". Haar voorstel was daarom de kaarten te gebruiken "als indicatie en niet als echt gegeven" en concludeerde dat het ontwerp dus "een improvisatie" was. Zij stelde daarom voor "in grote lijnen" en "met grove pennenstreken" te werken.

Desondanks bleef het gevoel van willekeur voor de onderzoekers een struikelblok met het resultaat dat elke poging die werd genomen om de toekomst ontwerpend te verbeelden uiteindelijk werd afgeschoten met argument als "Dit is te mager", "er is geen onderbouwing" of "er is meer en diepgaander ruimtelijke analyse nodig". Doordat de grenzen verhard waren, werd er nog sterker met de maten van het eigen domein gemeten. Dit gold zowel voor de ontwerpen die worden gemaakt voor het nationale schaalniveau als het lokale/regionale schaalniveau. Eén van de ontwerpers legde uit:

"We hebben de ontwerpen samen (onderzoekers en ontwerpers, sk) een voor een doorgenomen en J. (de landbouwexpert, sk) was van mening dat de state-of-the-art al veel verder is dan in de ontwerpen is meegenomen. Het komt er op neer dat de ontwerpen niet zijn gebaseerd op de laatste inzichten en dus nogal achterhaald zijn. Het waren leuke plaatjes, maar ze klopten volgens hem inhoudelijk niet" (Projectbijeenkomst VVR, 25 augustus 2003).

En in een memo van de projectleider aan de eindverantwoordelijke las ik dat:

"het ontwerp dat gemaakt was te licht is om als RPB naar buiten te brengen (geen toegevoegde waarde t.o.v. reeds verrichte ontwerpstudies van anderen (VVR Memo projectleider, 17 september 2003).

Vanuit het idee dat het ontwerp onvoldoende onderbouwd, niet systematisch en daarom te willekeurig was, werden alle ontwerpen gedegradeerd door ze te positioneren als "plaatje" of "illustratie" bij het onderzoek. De ontwerpen kwamen dus in de invloedssfeer van het onderzoek en er ontstond een hiërarchie, waarbij het ontwerp ondergeschikt werd gemaakt aan het onderzoek.

Hoe kunnen we dit verklaren? Door het sneuvelen van potentiële grensoverschrijdende objecten werd in de loop van de toekomstverkenning het grensverkeer tussen 
onderzoekers en ontwerpers geblokkeerd. Dit blijkt ook uit de discussie naar aanleiding van de vraag van de projectleider hoe de ontwerpen tot stand zijn gekomen:

Onderzoeker 1:

Onderzoeker 2:

Projectleider:

Onderzoeker 3:
"In overleg met de inhoudsdeskundigen (= onderzoekers, sk) neem ik aan."

"Nee, niet. Ik heb vanochtend op mijn bureau eindelijk een beschrijving gezien van wat voor ideeën eigenlijk achter de ontwerpen zitten".

"Hoe kan dat? Even voor mijn begrip: was het niet de bedoeling om ze in overleg met de deskundigen te ontwerpen?".

"Dat is het volgens mij het grote probleem, iedereen was voor zichzelf bezig. Het ontwerpen gebeurde los van het verhaal (het onderzoek, sk). We hebben de link niet kunnen leggen tussen het verhaal en de ontwerpen".

Onderzoekers en ontwerpers zijn steeds meer van elkaar gaan 'vervreemden' en gingen steeds onafhankelijker van elkaar, dus binnen hun eigen domein, de toekomst verkennen. Zo vertelde één van de onderzoekers dat zij in de loop der tijd "veel tijd" is gaan steken in het krijgen van "zo goed mogelijke sectorale cijfers" (Projectbijeenkomst WR, 25 augustus 2003) in plaats van de afstemming met het ontwerp. Er is dus niet langer sprake van een vervreemdingsmodel, maar van een "hiërarchisch model", waarbij de onderzoekers domineren en de ontwerpers ondergeschikt waren.

Dus eerst werden de door de ontwerpers gemaakte producten gedegradeerd van toekomstverkenning tot "plaatjes" en vervolgens verdween het ontwerp als toekomstverkenningsactiviteit. Omdat er geen grensgebied meer was en het vervreemdingsmodel was verschoven naar een hiërarchisch model kwam het ontwerp als vorm van toekomstverkenning uiteindelijk in het geding.

In een overleg met de planbureaudirecteur/eindverantwoordelijke constateerde één van de ontwerpers dat het ontwerp letterlijk en figuurlijk helemaal niet meer op de agenda stond en vroeg daarom of het klopte dat er "niets meer over het ontwerp in de verkenning" komt. De planbureaudirecteur beaamde dit door te stellen: "Volgens mij sta jij nergens meer genoemd, dus ben jij gewoon vanaf heden vrij", dat wil zeggen ten behoeve van het WR-project. Dit resultaat van het verloop van het grenzenwerk (wat vooral bestond uit het trekken en versterken van grenzen) was dat de toekomstverkenning onmiskenbaar een onderzoekersverkenning werd. De ontwerpers kregen uiteindelijk een zeer marginale rol toegewezen in de laatste fase van de toekomstverkenning, namelijk het zorgen "voor de plaatjes".

Het lukte de toekomstverkenners dus niet om een solide werkrelatie tussen onderzoekers 
en ontwerpers te construeren en daarmee samenwerking mogelijk te maken. Hoewel in het oorspronkelijke samenwerkingsverdrag onderzoekers en ontwerpers formeel werden beschouwd als gelijkwaardige partners, kwam gedurende het project het primaat steeds meer te liggen bij de onderzoekers en zijn de ontwerpers steeds meer een marginale en ondergeschikte rol gaan vervullen in het project. Met als resultaat dat de toekomstverkenning veranderde van een (potentieel) geïntegreerd onderzoeks/ ontwerpproduct naar een onderzoeksproduct.

\subsection{De integratieambities sneuvelen}

Wat betekent het sneuvelen van ontwerp voor het realiseren van de integratieambities? De ambitie tot integraliteit leek de toekomstverkenners lange tijd te stimuleren door te gaan en te blijven zoeken naar manieren waarop integratie tot stand zou kunnen komen. Zo spoorde één van de toekomstverkenners de anderen aan:

"We moeten blijven zoeken naar een kader waarbinnen we alle inzichten kunnen integreren" (Projectbijeenkomst VVR, 21 augustus 2003).

In het VVR-project zag ik dat, ondanks het gedeelde 'commitment' de integratieambities te realiseren, dezelfde ambities het proces van toekomstverkennen blokkeerden. De hoge verwachtingen die de toekomstverkenners hadden, leidden ertoe dat niets wat zij produceerden in hun ogen voldeed aan hun eigen integratie-ideaal. Zo zagen we dat alle potentieel grensoverschrijdende objecten sneuvelden. De toekomstverkenners bleken niet in staat gemeenschappelijke noemers te vinden en de verschillende sectoren/ thema's, schaalniveaus, disciplines, aannames/veronderstellingen, tijdshorizonnen, analyse-eenheden, ruimteclaims, kwantitatieve en kwalitatieve inzichten of culturen van toekomstverkennen op een (in hun ogen) zinvolle manier over en weer in beeld te brengen. En met het sneuvelen van het ontwerp gingen ook de integratieambities langzaam ten onder.

Na maanden van discussiëren en onderhandelen werd de integratieambitie, zoals deze aan het begin van het project was geformuleerd, uiteindelijk expliciet losgelaten:

"We moeten niet de illusie hebben dat het een intersectoraal, geïntegreerd verhaal gaat worden. Het wordt eerder een verhaal waarin je vanuit sectorale problemen redeneert" (Projectbijeenkomst VVR, 20 augustus 2003).

De toekomstverkenners leken zich erbij neer te leggen dat zij hun integratieambities niet zouden realiseren in deze toekomstverkenning. In een memo aan de planbureaudirecteur lichtte de projectleider het besluit de integratieambities los te laten toe aan de directeur. 
Hij legde daarbij uit dat het enthousiaste werken "vele ideeën" opleverde, maar "geen ontwerpen". De toekomstverkenners deelden de directeur uiteindelijk mee dat na veel overleg door het projectteam was besloten over te gaan op wat zij noemen "plan B" waarin de ambitie om te komen tot "een geïntegreerd resultaat" was losgelaten. Hij schreef:

"de ambitie om op elk vlak met eigen ontwerp te komen wordt verlaten. Er wordt maximaal gebruik gemaakt van de goede dingen die uit de studies en ontwerpen die tot nu toe voor de verkenningen zijn gemaakt. Nieuwe ontwerpen zullen niet worden gemaakt, wel kunnen bestaande ontwerpen verder worden verbeterd. Er zal meer gebruik worden gemaakt van bestaande ontwerpen uit andere (RPB, sk) projecten (..) en van anderen (..). Belangrijke overweging hierbij is ook de beheersbaarheid van het proces. Voor het maken van nieuwe ontwerpen is veel analyse nodig en van te voren is slecht te plannen hoeveel werk het kost" (VVR Memo projectleider, 17 september 2003).

De projectleider concludeerde tenslotte:

"Ik moet (..) dus concluderen dat het niet lukt voor alle vier de onderwerpen met kwalitatief voldoende ontwerpen te komen. De huidige opzet van de VVR is dan niet houdbaar. De ambitie als ontwerpend planbureau kan maar voor een deel (Water, misschien Landbouw) worden gerealiseerd" (VVR Memo projectleider, 17 september 2003).

$\mathrm{Na}$ een jaar en drie maanden hard werken aan 'integratie' verlieten de toekomstverkenners hun integratieambities ${ }^{48}$.

\footnotetext{
${ }^{48}$ Het sneuvelen van de integratieambities in de VVR-toekomstverkenning staat echter niet op zichzelf. Zo constateren van der Duin, Hazeu, Rademaker, \& Schooneboom (2004), die anno 2004 de toekomstverkenning van de WRR uit 1977 tegen het licht hielden, dat "the failures are also there such as initial attempts to craft an integral model, or the only partially successful integration of surveys in subsectors, where there was a shortfall in interdisciplinary knowledge around linkage" (238). Ook laten zij zien dat de integratieambitie in deze toekomstverkenning in de loop van de tijd werd bijgesteld. Toen het rapport na vier jaar verkennen verscheen, zo constateren zij, waren de doelstellingen minder ambitieus dan de originele ambitie. Zo sprak men bijvoorbeeld niet meer van 'integraal', maar van 'algemeen' en niet in termen van waarschijnlijkheid, maar van 'an image of the future' (van der Duin, Hazeu, Rademaker, \& Schooneboom, 2006).
} 


\subsection{Van integratie naar variatie}

Betekent het niet kunnen realiseren van integratieambities dat de toekomstverkenning in de ogen van de toekomstverkenners was mislukt? De discussies van de laatste weken van de toekomstverkenning lijken dit te bevestigen. Zo was één van de onderzoekers van mening dat ze in de korte tijd die zij nog hebben hooguit "een artikeltje" en "geen verkenning" konden schrijven. Een van hen stelde: "Wat we ook doen, het blijft een product van inferioriteit". En geen van de toekomstverkenners was uiteindelijk bereid zijn of haar naam aan het eindproduct te verbinden: "Wij willen absoluut niet dat onze naam erop komt" (Projectbijeenkomst VVR, 28 augustus 2003) ${ }^{49}$. De toekomstverkenners leken geen genoegen te nemen met wat zij noemden een "sectorale verkenning" en "aan het huidige resultaat willen ze hun naam niet verbinden" (VVR Memo projectleider, 17 september 2003).

Toch verscheen enkele maanden later geen artikeltje, maar een lijvig eindrapport mét de namen van de toekomstverkenners. Wat gebeurde er in de tussentijd? In de laatste fase van de toekomstverkenning was een centrale rol weggelegd voor de directeur. Zich realiserend dat de publicatie van de toekomstverkenning in het geding was, besloot hij in de laatste fase het projectleiderschap op zich te nemen en een nieuw uitgangspunt te formuleren voor de verkenning. Het centrale uitgangspunt was de observatie dat de samenleving "steeds complexer" en "ongekender" geworden (RPB, 2003a: 13). Hiermee appelleerden zij dus aan de ideeën over de 'nieuwe' manier van toekomstverkennen. Ook stelden zij dat, terwijl de samenleving fundamenteel is veranderd "het traditionele denken" - wat zij omschreven met de woorden "sectoraal" en "planmatig" - in de ruimtelijke ordening nog dominant is. Dit traditionele sectorale en planmatige perspectief op de ruimtelijke ordening werd echter ter discussie gesteld, omdat het, aldus de auteurs, de vraag was of het de toekomstige ruimtedruk zou oplossen. Als alternatief presenteerden de toekomstverkenners een "nieuwe", "andere" of "aanvullende" manier van leren dat redeneerde vanuit "variatie en selectie". Deze nieuwe manier van leren betekende, aldus de auteurs, "veel alternatieve handelingswijzen" of een "variëteit aan alternatieven" genereren en beproeven. Het ging dus niet om variatie van toekomstbeelden, zoals in SCENE, maar om variatie in handelingsalternatieven.

Dit is opmerkelijk, want, hoewel de ambitie tot variatie wel uitgesproken werd aan het begin van het project, was deze ambitie in de loop van het project steeds meer uit het vizier van de toekomstverkenners verdwenen. In het verkennen van de toekomst, in de dagelijkse praktijk, speelde deze ambitie nauwelijks een rol. Ik zou zelfs kunnen beargumenteren dat er tijdens het proces van toekomstverkennen sprake was van een variatieaversie. De toekomstverkenners gaven tijdens het project namelijk

\footnotetext{
${ }^{49} \mathrm{Bij}$ het RPB is het namelijk gebruik om te werken met auteurs. Anders is dit bijvoorbeeld bij het MNP.
} 
meermalen nadrukkelijk te kennen dat zij "geen scenario's maar prognoses" maakten (in tegenstelling tot bijvoorbeeld de toekomstverkenners in SCENE). Dit type opmerking illustreert dat de toekomstverkenners niet alleen onverschillig waren ten aanzien van variatie, maar bijna 'anti'. En deze variatieaversie leek geworteld te zijn in hun opvattingen over wat goed onderzoek doen is en wat wetenschappelijk verantwoord is, namelijk dat verankering in de historie de enige manier is waarop uitspraken over de toekomst te onderbouwen zijn. In hun variatieaversief betoog hanteerden de toekomstverkenners een jargon waarin termen als "realistisch", "plausibel", "logische" en "verantwoord" de boventoon voerden. Ook de term bandbreedtes gaven deze toekomstverkenners een andere betekenis, namelijk bandbreedtes die niet te veel afwijken van historische realisaties in plaats van "bandbreedtes opzoeken". Ook het argument "dat wel uitgelegd moet worden waarom toekomsten afwijken van de trends" kan worden opgevat als onderdeel van een variatieaversief betoog.

De variatieambitie was ook in de ogen van de toekomstverkenners een nieuwe ambitie. Dit blijkt ook uit opmerkingen als "dit is een hele andere insteek", "dit is iets heel anders dan wat we tot nu toe gedaan hebben" en "dit is een heel ander verhaal dan we de afgelopen maanden wilden vertellen" (Projectbijeenkomst WVR, 12 september 2003). Toch wist de directeur de toekomstverkenners te mobiliseren voor deze 'nieuwe' insteek. Hij legde de toekomstverkenners uit dat het geen op zichzelf staande, "realistische analyses" voor Wonen, Werken, Water en Landbouw waren, maar bouwstenen die kunnen worden ingezet om het belang van "een andere kijk" op ruimtelijke ordening te onderstrepen. Door deze ingreep slaagde de directeur erin de sceptisch geworden toekomstverkenners te verleiden zich weer in te zetten voor het tot stand komen een verkenning in de vorm van een rapport. De variatieambitie bood de toekomstverkenners dus een nieuw kader waarbinnen zij de sectorale analyses een nieuwe betekenis konden geven, namelijk als "tamelijk willekeurig gekozen" beleidsterreinen waarvan de mogelijkheden van deze nieuwe benadering werd verkend. In het rapport stelden de toekomstverkenners bijvoorbeeld:

"Als we in dit boek de toekomstige ruimteclaims hadden willen verkennen, dan hadden we niet met deze vier sectoren kunnen volstaan en hadden we ook de overige sectoren onder de loep moeten nemen. Het gaat er echter om een andere manier te verkennen van omgaan met ruimteclaims. Dan kan met vier beleidsterreinen worden volstaan, op voorwaarde dat ze voldoende gevarieerd zijn" (RPB, 2003a: 21).

Eén van de toekomstverkenners stelde zelfs voor de term "prognoses" te vervangen door "vooruitbeschouwingen", omdat de term prognose volgens hem te veel associaties zou oproepen met de "oude" verkenningstraditie (Projectbijeenkomst VVR, 14 oktober 2003). In het eindrapport wordt de term prognose nog wel gebruikt. 
Binnen dit nieuwe kader kregen zelfs ontwerpen die eerder door de onderzoekers waren gediskwalificeerd als zijnde "te licht", "te mager" en "te weinig onderbouwd" een nieuwe functie toebedeeld, namelijk als "een palet" (= variatie) aan ideeën waaruit de beleidsmaker mogelijke oplossingen voor toekomstige (water)problemen kan selecteren.

De toekomstverkenners formuleerden wel een andere ambitie, maar dat veranderde niet de resultaten die de toekomstverkenning tot dusver had opgeleverd. Met andere woorden, in het proces was geen aandacht voor variatie ${ }^{50}$, terwijl de inhoudelijke hoofdstukken uiteindelijk wel onderdeel moesten worden van het variatiebetoog in de toekomstverkenning. Dat de toekomstverkenning uiteindelijk op twee gedachten hinkte werd ook opgemerkt door de toekomstverkenners zelf. Het materiaal dat het onderzoek had opgeleverd was dus geen 'variatiemateriaal' (in de zin van variatie ten aanzien van toekomstbeelden), maar moest wel als zodanig naar buiten toe worden gepresenteerd. Dit deden zij door de set van traditionele sectorale analyses volgens het nieuwe, hedendaagse beeld op toekomstverkennen te verpakken en het proces van toekomstverkennen buiten beeld te laten. We zien hier, met andere woorden, dat toekomstverkenners 'variatie doen' door retoriek te herstellen, argumentatief werk en de ambities te transformeren.

En zo gebeurde het dat in december 2003, zoals gepland (het planbureau had beloofd in 2003 de eerste ruimtelijke verkenning te publiceren) het rapport 'De ongekende ruimte verkend' verscheen.

\subsection{Samenvatting}

Ik heb laten zien dat het de toekomstverkenners niet lukt om de potentiële grensoverschrijdende objecten te construeren op het grensgebied van onderzoek en ontwerp die voldoende "plastic" en "robuust" zijn om samenwerking en daarmee de integratieambities mogelijk te maken. Doordat de toekomstverkenners de potentiële

\footnotetext{
${ }^{50}$ Het hoofdstuk over de Landbouw is letterlijk en figuurlijk een ander verhaal. In dit hoofdstuk lijkt wel te zijn geschreven vanuit de variatieambitie. Dit blijkt bijvoorbeeld uit de keuze om geen prognoses, maar scenario's te ontwikkelen. In dit hoofdstuk wordt dan ook gesproken van "een hoge mate van onzekerheid ten aanzien van de toekomst" van de landbouw. De scenario's moeten daarom inzicht bieden in de "verschillende onzekere factoren" en "de meest uiteenlopende gevolgen" (RPB, 2003a: 119-20). Hier was dus wel variatie gecreëerd ten aanzien van toekomstbeelden. Niet alleen inhoudelijk, maar ook projectmatig gezien was het thema Landbouw een buitenbeentje. De sectordeskundige voor het thema Landbouw was namelijk geen onderdeel van het projectteam en opereerde min of meer zelfstandig en onafhankelijk.
} 
grensoverschrijdende objecten verplaatsten uit het grensgebied, was het niet mogelijk om een infrastructuur te bouwen waarlangs samenwerking kon gaan plaatsvinden.

En hierdoor werd het grensverkeer tussen beide domeinen geblokkeerd. Het grensgebied vervaagde, de grenzen tussen beide domeinen werden versterkt en er ontstond als het ware een niemandsland of 'no go-area'. En het integratiemodel dat de toekomstverkenners voor ogen hadden transformeerde in een 'vervreemdingsmodel' waarin onderzoekers en ontwerpers steeds onafhankelijker van elkaar, dus binnen hun eigen domein, de toekomst gingen verkennen.

Ook heb ik laten zien dat er aan het einde van het project een hiërarchie zichtbaar werd tussen onderzoekers en ontwerpers, waarbij het ontwerp ondergeschikt gemaakt werd aan het onderzoek. Er is dan niet langer sprake van een vervreemdingsmodel, maar van een 'hiërarchisch model', waarin de onderzoekers domineerden. Uiteindelijk degradeerden de onderzoekers de door de ontwerpers gemaakte producten van toekomstverkennen tot "plaatjes" en vervolgens verdween het ontwerp als toekomstverkenningsactiviteit. Ik heb laten zien dat, omdat er geen grensgebied meer was, en het vervreemdingsmodel was verschoven naar een hiërarchisch model, het ontwerp als vorm van toekomstverkenning uiteindelijk in het geding kwam.

Sommige toekomstverkenners wezen op het gebrek aan verantwoordelijkheidsgevoel en betrokkenheid van een aantal toekomstverkenners bij het project en de wil om samen tot een eindproduct te komen. Mijn ervaring was echter dat de betrokkenheid juist erg groot was, dat de toekomstverkenners veel energie gestoken hebben in het realiseren van hun gestelde ambities en dat zij zeer gedreven waren om de toekomstverkenning tot een goed einde te brengen. Andere toekomstverkenners hebben het sneuvelen van de integratieambities proberen te duiden door te wijzen op het bestaan van onoverbrugbare verschillen in taal en cultuur tussen onderzoekers en ontwerpers. Hoewel de toekomstverkenners zelf de verklaring zoeken in een taal- en cultuurverschil leek er meer aan de hand te zijn. Verschillende wetenschapssociologen (Star, 1989; Star, 2002; Star \& Griesemer, 1989); (Fujimura, 1992); (Latour, 1988, 1999) hebben in het verleden namelijk ook situaties beschreven waarin sprake was van een taal- en cultuurverschil, maar waar dat geen belemmering vormde voor samenwerking.

Achter de moeizame samenwerking tussen onderzoekers en ontwerp en het sneuvelen van de integratieambitie lijkt een dieper liggend 'probleem' te schuilen. In het volgende hoofdstuk zal ik proberen te verklaren waarom de toekomstverkenners er niet in slaagden de integratieambitie te realiseren en waarom het realiseren van de variatieambitie, zoals ik dat heb beschreven in hoofdstuk 3, zo moeizaam was. 
A trend is a trend is a trend, But the question is, will it bend? Will it alter its course Through some unforeseen force And come to a premature end?

(Cairncross, 1969), geciteerd in Armstrong (2001). 
(4)
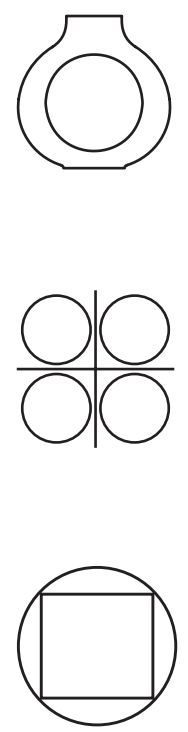

5 


\section{(5) Perspectieven op verleden, heden en de toekomst}

Ik begon mijn beschrijving en analyse van de praktijk van toekomstverkennen met de observatie dat toekomstverkenners zichzelf tot doel stellen te verkennen vanuit het "niet weten" en verder willen gaan dan wat op basis van geobserveerde trends in verleden en heden over de toekomst kan worden gezegd. Veel toekomstverkenners trekken een scherpe scheidslijn tussen de, wat zij noemen, 'oude' en 'nieuwe' generatie toekomstverkenningen (zie ook Hoofdstuk 1, 3 en 4). 'Oud' staat dan voor het idee dat de toekomst kan worden voorspeld en 'nieuw' voor de opvatting dat voorspellen juist een illusie is. De nieuwe generatie toekomstverkenners zegt zich dus niet langer te richten op het voorspellen van de toekomst, maar op het verkennen van mogelijke toekomsten en het in kaart brengen van onzekerheid en complexiteit. Deze nieuwe toekomstoriëntatie komt in de praktijk tot uitdrukking in de variatie- en integratieambitie.

In de twee voorgaande hoofdstukken heb ik de wisselwerking laten zien tussen de ambities die toekomstverkenners zichzelf stelden (namelijk integratie en variatie) en de praktijk van toekomstverkennen. Daarbij heb ik laten zien wat de ambities praktisch inhouden. Daaruit kon geconcludeerd worden dat toekomstverkenners in de praktijk vaak een andere invulling of meerdere betekenissen geven aan deze ambities dan (h)erkend of zichtbaar gemaakt wordt in theoretische en/of methodologische verhandelingen. Ook heb ik laten zien dat het realiseren van de integratie- en variatieambities problematisch is, en tegelijkertijd dat het niet realiseren van de ambities niet automatisch betekent dat de toekomstverkenning "mislukt" (in de zin van dat er geen rapport verschijnt met uitspraken over de toekomst of dat de toekomstverkenners het zelf als mislukt ervaren). Mijn analyses laten zien dat er een verschil is tussen variatie en integratie doen en de manier waarop toekomstverkenners hierover communiceren en rapporteren. Er zijn, met andere woorden, grote, wezenlijke verschillen tussen de dagelijkse praktijk van toekomstverkenning en wat toekomstverkenners achteraf, als het verkennen van de toekomst is gedaan, zelf zeggen dat zij hebben gedaan. Ik zou nog meer verhalen kunnen vertellen die deze observaties ondersteunen. De vraag is echter of dat zinnig is. Gevalstudie-onderzoek is namelijk gericht op het vinden van algemeenheden, het krijgen van inzicht in dieperliggende patronen en structuren en het krijgen van stabiliteit in de beeldvorming van de praktijk (Yin, 1994). In dit hoofdstuk wil ik daarom beschrijven en analyseren waarom het zo moeilijk blijkt te zijn de variatie- en integratieambities te realiseren en waarom allerlei spanningen en tegenstrijdigheden ontstaan. Wat is er aan de hand? Is het zo dat toekomstverkenners hun methoden niet goed toepassen? Kunnen mensen niet samenwerken? Misschien. Maar dit is niet het verhaal dat ik nu wil gaan vertellen, omdat het geen recht doet aan het complexe en unieke karakter van de toekomstverkenningspraktijk. In dit hoofdstuk wil ik laten zien dat er sprake is van een dieper liggend probleem dat te maken heeft met de aard van toekomstverkennen.

In dit hoofdstuk zal ik reflecteren op de grondslagen van toekomstverkennen. Dit doe ik door mijn observaties uit de WLO toekomstverkenning te gebruiken en deze te koppelen aan observaties uit SCENE en WR. Ik beoog te analyseren hoe toekomstverkenners 
betekenis geven aan tijd. Ik ga, met andere woorden, gedetailleerder kijken naar 'de toekomst' als het object van onderzoek in toekomstverkenningen. Door te reflecteren op hoe toekomstverkenners omgaan met 'tijd' hoop ik te kunnen verklaren waarom het realiseren van de twee ambities van toekomstverkennen problematisch is.

\section{$5.1 \quad$ 'Tijd' in toekomstverkennen}

Waar gaat het in toekomstverkenningen over? Een bioloog bestudeert levende wezens en levensverschijnselen in algemene zin, een psycholoog de menselijke psyche en een toekomstverkenner de toekomst. Toekomstverkenning gaat over tijd, letterlijk over de tijd die voor ons ligt. Zelf stellen zij dat "understanding the (..) meaning of time is absolutely basic to futures thinking" (Bell, 2000). Toekomstverkenners situeren hun uitspraken in de toekomstige tijd. Toch blijft de betekenis die door toekomstverkenners wordt gegeven aan 'tijd' en 'toekomst' in toekomstverkennende studies vaak impliciet. De toekomst is dus iets wat steeds op tafel ligt, maar in toekomstverkenningen niet of nauwelijks wordt benoemd. Brier (2005), die verschillende toekomstverkenningen tegen het licht hield en een 'survey' onder toekomstverkenners heeft gedaan, stelt bijvoorbeeld "I am often left wondering whether the author means tomorrow, newt week, next decade, or next century" (Brier, 2005: 833) als toekomstverkenners het over de toekomst hebben.

Een manier waarop toekomstverkenners met tijd omgaan is het stellen van een "tijdshorizon" of "zichtjaar". Brier (2005) definieert de tijdshorizon van een toekomstverkenning als "how far into the past and how far into the future one's thinking goes" (833) en van der Heijden (1996) als "the chosen cut-off time of the scenario stories" (227). Volgens van der Heijden (1996) gebruiken toekomstverkenners de tijdshorizon "as a point on the time axes from which the scenarios look back to tell the "history of the future"" (227). Voor toekomstverkenners is de toekomst dus niet de eeuwigheid: de toekomst wordt door toekomstverkenners ingeperkt en verhalen over de toekomst kunnen zich ver of minder ver van het heden afspelen. Elke verkenningscontext lijkt een eigen tijdshorizon of referentiekader te hebben "for thinking about what the proper duration of "the present" ought to be" (Bell, 2000). In een medische context is de toekomst soms niet langer dan enkele minuten (Mesman, 2002); een weersvoorspeller kijkt vaak enkele dagen tot een week vooruit (Fine, forthcoming) en een geoloog die tektonische bewegingen in kaart wil brengen zal duizenden jaren vooruit kijken.

Observaties in de praktijk van beleidsgerichte toekomstverkenning laten zien dat toekomstverkenners vaak de jaartallen 2020, 2030, 2040 of 2050 gebruiken om de tijdshorizon te expliciteren. De tijdshorizon is dus zo'n vijftien, twintig, dertig en maximaal vijftig jaar. Beleidsgerichte toekomstverkenners beschouwen toekomstverkenningen over de hele lange termijn van honderd, honderden of duizenden jaren als pure speculatie.

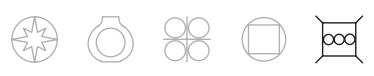


Ze doen uitspraken over die termijn vaak af als 'science fiction'. van der Duin, Hazeu, Rademaker, \& Schooneboom (2006) wijzen op het "gevaar" van wat zij noemen "romancing" en "willy-nilly expanding on personal images, preferences and tales" (240) en concluderen daarom dat in een beleidscontext kortere tijdshorizonnen van tien tot twintig jaar in veel gevallen "more significant" zijn (240). Brier (2005) signaleert dat toekomstverkenners bang zijn dat "increasing their time horizon could create the perception that their work would be characterized as science fiction" (Brier, 2005: 844). Toekomstverkenners lijken dus bang niet serieus genomen te worden als zij uitspraken doen die verwijzen naar ontwikkelingen die "te ver" in de toekomst liggen. Die angst lijkt geworteld in een bepaalde opvatting over wat wetenschap is en zou moeten zijn en waarvan ze veronderstellen dat die maatschappelijke 'anklang' heeft. Met andere woorden, toekomstverkenners lijken ook in te zetten op het mogelijke effect dat een bepaalde tijdshorizon zou kunnen bewerkstelligen bij hun publiek.

In de tijdshorizon van beleidsgerichte toekomstverkenningen liggen verschillende veronderstellingen besloten ten aanzien van wat de beleidsmakers verwachten van een verkenning en wat ze daarvoor nodig hebben. Zo wordt in het WLO Plan van Aanpak uitgelegd waarom gekozen is voor de tijdshorizon van veertig jaar:

"Tenslotte leert ook de ervaring bij de vorige scenariostudie (namelijk EFO, sk) dat de scenariotermijn niet te krap moet zijn. Toen is op verzoek van VROM een jaar na oplevering van de scenario's 1995-2020 alsnog een verlenging tot 2030 gemaakt".

Beleidsgerichte toekomstverkenners willen met hun toekomstverkenningen beleidsmakers ondersteunen en stimuleren in het maken van langetermijnbeleid. In SCENE wordt gesproken over het vergroten van de "werfkracht van de scenario's" door recht te doen aan "de praktijk die beleidsmakers ervaren" (SCENE Memo, 26 november 2001). Relevantie voor beleidsmakers is dus een thema dat een belangrijke rol lijkt te spelen in het "zetten" van de tijdshorizon. Het begrenzen van een tijdshorizon is dan op te vatten als een poging om degelijkheid, geloofwaardigheid en betrouwbaarheid te creëren.

Hedendaagse toekomstverkenners stellen vaak dat het besef dat de toekomst fundamenteel anders kan (of zelfs zal) zijn dan het heden hen heeft opgezadeld met een dilemma. Zo vertelde één van de toekomstverkenners bij het RPB: "We kunnen de toekomst niet kennen en hoe verder we in de toekomst willen kijken, hoe minder we weten" (Projectbijeenkomst VVR, 15 oktober 2003). Om voldoende zeggingskracht te behouden en een richting te kunnen bieden voor het huidige handelen in het hier en nu, moet de tijdshorizon volgens toekomstverkenners niet al te ver weg liggen. Toekomstverkenners lijken vaak niet verder dan 30, 40 of 50 jaar vooruit te willen kijken vanuit het idee dat de toekomstverkenningen, indien zij te onbereikbaar zijn, niet kunnen functioneren als "verwachtingshorizon" (de Wilde, 2000): een toekomstverkenning 
moet niet te "speculatief" of, zoals zij zelf vaak zeggen, niet te "exotisch" zijn. Aan de andere kant moet de horizon ook weer niet te veel binnen bereik liggen omdat toekomstverkenners ervan overtuigd lijken dat dat de mogelijkheid nieuw licht op de toekomst te werpen verkleint. Dit spanningsveld wordt treffend verwoord door Calder: "Short-term forecasts tend to be dull and obvious, long-term forecasts provocative and unreliable" (Calder, 1969), geciteerd in de Wilde (2000). Hoe gaan toekomstverkenners om met dit spanningsveld? Hoe balanceren toekomstverkenners tussen kennen met relatieve zekerheid en verkennen in totale onzekerheid? Hoe balanceren zij het waarschijnlijke en het (on)mogelijke, het bekende en het nieuwe?

\subsection{Verschillende temporele repertoires}

In de literatuur wordt vaak een onderscheid gemaakt tussen twee verschillende temporele repertoires, waarvan wordt verondersteld dat die in de praktijk naast elkaar bestaan $^{51}$, namelijk het lineaire repertoire en het cyclische repertoire. In het lineaire repertoire wordt tijd opgevat als "continuous, linear, unidirectional and irreversible" (Bell, 2000: 140) en de toekomst als een "extended present". Het idee van "extended present" werd voor het eerst geïntroduceerd in 1966 door Husserl, die sprak over "the horizons of a temporally extended present", waarmee hij niet alleen verwees naar het hier en nu, maar ook naar het terugkijken naar het directe verleden en het vooruitkijken naar de directe toekomst (vergl. Neisser (1976); Gell (1992) en Nowotny (1994)). Gell (1992) spreekt van "past and future phases of current events, that fuse with them to create consciousness of the present" (223-4). Hij beschouwt de betekenis van tijd dus als een dynamisch proces waarin mensen herinneren en vooruitkijken om betekenis te kunnen geven aan het heden. STS-sociologe Nowotny (1994) legt een verbinding tussen dit tijdsrepertoire en de opkomst van wat zij noemt 'instantaneous time' - de beleving dat ontwikkelingen zich in een steeds sneller tempo opvolgen, of, met andere woorden, het versnellen van de tijd: "( $t$ )he sense of increasing pace as affecting our views of the future to the extent we now see ourselves as living in an extended present" (31-2). In dit repertoire wordt, met andere woorden, causaliteit en temporele continuiteit verondersteld. Dit wil zeggen dat het verleden, heden en toekomst beschouwd worden als onlosmakelijk met elkaar verbonden. Gebeurtenissen in verleden, heden en de toekomst worden opgevat als onderdeel van een "onomkeerbaar" en "coherent ontwikkelingsproces" (van Vree, 1998: 13).

In een cyclisch perspectief ${ }^{52}$, daarentegen, worden gebeurtenissen in heden en verleden

\footnotetext{
${ }^{51}$ Zie bijvoorbeeld Gurevich (1976); Bell (2000) en Mesman (2002).

${ }^{52}$ Het cyclische repertoire wordt vaak gerelateerd aan traditionele samenlevingen, waarin het bestaan van mythen en rituelen werden beschouwd als bewijzen van "goddelijke voorzienigheid of
}

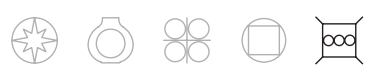


beschouwd als terugkerende, maar afzonderlijke "momenten in de natuurlijke kringloop" (van Vree, 1998: 10) - zoals de jaargetijden, de getijden eb en vloed en dag en nacht. Ontwikkelingen in het heden en verleden fungeren in dit tijdsrepertoire als spiegel waaraan lessen voor de toekomst kunnen worden ontleend.

In de Westerse samenleving is de lineaire tijdsperceptie dominant. De Duitse historicus en geschiedfilosoof Koselleck (1985) lokaliseert de oorsprong van deze tijdsbeleving, waarnaar hij verwijst met de term 'geschichtliche Zeit', aan het eind van de achttiende eeuw. In deze periode ontstond onder invloed van het Verlichtingsdenken een omwenteling in de perceptie van de werkelijkheid en daarmee in de relatie die werd gelegd tussen verleden, heden en de toekomst. Auteurs als Adam (1994) en Bowker (forthcoming) verbinden de opkomst van dit lineaire denken aan het industrialisatieproces. Adam (1994) laat zien hoe de industrialisatie ervoor heeft gezorgd dat tijd "spatialised, abstracted and mathematised" werd. Hij spreekt in deze context van "clock time", waarin tijd wordt beschouwd als "to be passing, a stream in which we are caught, periodised in our familiar units of seconds, minutes, hours and so on and so forth".

Ook in de literatuur over toekomstverkennen zijn verwijzingen naar een lineaire tijdsopvatting terug te vinden. Naar dit perspectief zal ik verwijzen met de termen 'het historisch-deterministische perspectief'. Volgens Bell (2000), auteur van het boek Foundations of Futures Studies is één van de belangrijkste vragen die toekomstverkenners bezighoudt: "Are the historical situations to be used as analogies sufficiently similar to the future situations or events in question to permit any reasonable deduction from past knowledge to future possibilities?" (177). Daarbij stelt hij dat toekomstverkenners ervan uitgaan dat "(s)ome things that now exist or are developing can be expected to continue into the future and to have implications for shaping the future" (178). Armstrong, auteur van het boek Principles of Forecasting (2001), laat zien dat toekomstverkenners ervan uitgaan dat de onder beschouwing zijnde variabele "will continue in the future as it has behaved in the past" (218). Michael (2000) verwijst naar dit historisch-deterministische perspectief als een vorm van rationaliteit waarin toekomstverkenners hedendaagse randvoorwaarden, die zij beschouwen als "fundamental or foundational", projecteren op de toekomst en concludeert dat "( $t$ )hey are thus making claims about the longevity of certain fundamental aspects of the present and, relatedly, the foreseeability of certain fundamental aspects of the future" (29). Dergelijke toekomstverkenners veronderstellen dus een grote mate van temporele continuitteit. Het idee is dus dat dankzij het bestaan van deze temporele continuïteit het mogelijk is de toekomstige situatie te analyseren. In dit perspectief zijn uitspraken over de toekomst dus "realistisch" wanneer zij direct terug te voeren zijn op geobserveerde ontwikkelingen in het verleden en heden. 
In toekomstverkenning kan echter een tweede perspectief worden onderscheiden en dat is niet het cyclische perspectief. In dit tweede perspectief is het uitgangspunt dat de toekomst per definitie ongekend en onkenbaar is. Toekomstverkenners die dit perspectief op de kenbaarheid van de toekomst aanhangen, benadrukken dat we niet veel weten over de toekomst, behalve dat deze 'anders' zal zijn. In dit perspectief gaan toekomstverkenners ervan uit dat het verleden onvoldoende aanknopingspunten biedt voor het legitimeren van uitspraken over de toekomst. Deze toekomstverkenners pleiten er voor structuren en patronen die we nu kennen en in het verleden hebben gezien, in het verkennen van de toekomst los te laten. Volgens deze toekomstverkenners is het dus juist niet realistisch dat de wereld in de toekomst zal zijn zoals deze in het verleden was. Zulke toekomstverkenners richten zich niet op temporele continuïteit, maar op de analyse van onzekerheden, discontinuïteiten, of, zoals de WLO-toekomstverkenners dat noemden, "exogene schokken". Naar dit perspectief zal ik vanaf nu verwijzen met de term 'discontinuïteitsperspectief'.

Ook naar dit perspectief vinden we verwijzingen in de literatuur over toekomstverkennen. Lempert, Popper, \& Bankes (2003) stellen bijvoorbeeld dat "the future is influenced and constrained, but not determined by the past and the present" (30). En Clark (1986) stelt dat "by leaving out the external shocks, non-linear responses and discontinuous behaviour" in toekomstverkenning zal de samenleving niet voorbereid zijn om te gaan met "not-impossible eventualities". Deze toekomstverkenners stellen dat het opsporen van potentiële discontinuïteiten de centrale doelstelling zou moeten zijn in toekomstverkenning.

Er kunnen in de literatuur dus twee extreme perspectieven op toekomstverkenning worden onderscheiden, waarin verleden, heden en toekomst op een fundamenteel andere manier worden verknoopt. Enerzijds is dat het perspectief, waarin de toekomst wordt beschouwd als een logische uitkomst van eenduidige causale relaties die in het verleden en heden kunnen worden geobserveerd en kunnen worden doorgetrokken naar de toekomst. In het andere perspectief wordt het denken in continuïteiten doorbroken en gaan toekomstverkenners ervan uit dat de toekomst ook anders zou kunnen zijn. De 'oude' traditie van voorspellen is geworteld in een historisch-deterministisch perspectief op de relatie tussen verleden, heden en de toekomst, waarbij toekomstverkenners het verleden en heden beschouwen als determinant voor de toekomst. Omdat de door ons geobserveerde toekomstverkenners hun toekomstverkenning positioneerden binnen de 'nieuwe traditie' is het aannemelijk dat in het proces van toekomstverkennen juist ruimte wordt gegeven aan redeneringen waarbij het denken in temporele continuiteiten wordt losgelaten en daarmee aan het verkennen van onzekerheden en discontinuïteiten. Hoe is dat in de WLO-toekomstverkenning? Verlaten zij de 'oude' historisch-deterministische redeneerpatronen en breken zij met temporele continuïteiten? 
In dit hoofdstuk zal ik de verschillende temporele repertoires van de toekomstverkenners in de WLO-toekomstverkenning beschrijven en analyseren. Repertoires zijn als het ware verschillende gestabiliseerde patronen van denken en doen (Bal, Bijker, \& Hendriks, 2002) of, met andere woorden verschillende "stijlen van redeneren" (Mesman, 2002). We kunnen temporele repertoires dus opvatten als sturende principes die toekomstverkenners inzetten om kennis over het verleden en heden te kunnen ordenen en mobiliseren om verhalen over de toekomst een interne logica te geven en daarmee te kunnen legitimeren (vergl. Mesman (2002) ${ }^{53}$ ). Het identificeren van deze stijlen van redeneren is als het ware een tweede orde analyse van mijn empirische materiaal.

\title{
$5.3 \quad$ 'Tijd' in de WLO-praktijk
}

In de WLO-toekomstverkenning namen de toekomstverkenners expliciet afstand van de 'oude' voorspellende traditie, en het daarbij horende deterministische repertoire, door te stellen dat:

\begin{abstract}
"Wat kunnen we eigenlijk nog zeggen over een leefomgeving die bijna 40 jaar in de toekomst ligt? Veertig jaar geleden was er nog geen PC of internet en nog nauwelijks televisie. We hadden een verzuilde samenleving die draaide om het kostwinnersgezin en nauwelijks allochtonen kende. Vervoer ging nog vooral over spoor en water en we schakelden net over van steenkool naar gas. Wat hadden we toen voor Nederland anno 2000 kunnen voorspellen?" (WLO Plan van Aanpak, 2003: 4).
\end{abstract}

De toekomstverkenners stelden dat de toekomst "anders" kan, of zelfs zal, zijn dan het heden en verleden. Dit komt bijvoorbeeld tot uitdrukking in het voorstel de effecten van een aantal "exogene schokken" te doordenken en analyseren en in beeld te brengen (WLO Plan van Aanpak, 2003). De toekomstverkenners dachten daarbij bijvoorbeeld aan "effecten van zeer extreme zeespiegelstijging", "het eerder plaatsvinden van een demografische omslag", "zeer langdurige energieschaarste", "nieuwe energievormen" of "nieuwe vervoersvormen" (WLO Plan van Aanpak, 2003). Het doordenken en analyseren

\footnotetext{
${ }^{53}$ Mesman (2002) maakt een onderscheid tussen repertoires, die zij koppelt aan het 'redeneren en legitimeren' van actoren, en vocabulaire, dat zij betrekt op het 'spreken en interpreteren'. Andere auteurs, zoals Wenger (1998), maken dit onderscheid niet, maar beschouwen het vocabulaire als een van de elementen van een repertoire: "The repertoire of a community of practice includes routines, words, tools, ways of doing things, stories, gestures, symbols, genres, actions, or concepts that the community has produced or adopted in the course of its existence, and which have become part of its practice (..) It includes the discourse by which members create meaningful statements about the world, as well as the styles by which they express their forms of membership and their identities as members" (Wenger, 1998: 82-3).
} 
van deze 'nieuwe tijd' vereiste volgens hen het loslaten van "huidige culturen en structuren".

Hoe gingen de toekomstverkenners te werk in het verkennen van deze 'nieuwe' toekomst? In de WLO-documenten las ik dat de toekomstverkenners beoogden een glimp op te vangen van de nieuwe tijd door wat zij noemden "ontwerpend" de toekomst te verkennen. Door bekende structuren en patronen los te laten en het vertrouwde denken in continuïteiten (proberen) te doorbreken, wilden zij nieuwe ontwikkelingen op het spoor komen en verder doordenken. Met "ontwerpend denken" verwezen zij naar het loslaten van zekerheden, en met de aandacht voor nieuwe, "nog niet bestaande" culturen, structuren en ontwikkelingen. De toekomstverkenners leken te suggereren dat er veel ontwikkelingen zijn waarvan niet duidelijk is of, en zo ja welke rol, deze zullen spelen in de toekomst en dat ontwikkelingen in heden en verleden niet zondermeer kunnen worden beschouwd als determinant voor de toekomst. Toekomstverkennen vanuit de deze toekomstoriëntatie impliceert, met andere woorden, dat toekomstverkenners afstand nemen van het historisch deterministisch perspectief.

Het verkennen van wat zij noemden "de verre toekomst" verbonden de toekomstverkenners met de periode van 2020 tot 2040. Eén van de toekomstverkenners stelde:

"Na 2020 treden er gewoon allemaal dingen op die we niet kennen. De dynamiek zal wel eens heel anders kunnen zijn in de toekomst. De scenario's die nu het hardst groeien, kunnen straks wel het hardst gaan dalen" (Projectbijeenkomst WLO, 17 augustus 2004).

Een ander stelde dat "mechanismen uit het verleden na 2020 wel eens heel anders zouden kunnen uitpakken dan we in het verleden hebben gezien" (Projectbijeenkomst WLO, 23 augustus 2004). De toekomstverkenners in WLO kozen er dus voor de toekomst op te breken door twee tijdshorizonnen te onderscheiden: de eerste tijdshorizon lieten zij lopen van 2000 tot 2020 en de tweede van 2020 tot 2040 .

De eerste periode karakteriseerden zij met de "korte termijn" en "waarschijnlijke toekomst". Over deze periode zeiden zij dat zij de historische trends min of meer kunnen doortrekken. Zij stelden dat voor deze periode "mechanismen van de afgelopen 20 jaar goeddeels bruikbaar zijn om waarschijnlijke trends op het gebied van bevolking, water, energie en bijvoorbeeld Europese ontwikkelingen te herkennen en te verkennen" (WLO Discussiedocument, 2003). Om de waargenomen regelmaat en causaliteiten in het verleden vast te stellen, zeiden zij historische datasets met zogenaamde "tijdreeksen" te kunnen gebruiken. De variabelen die historisch gezien een bepaalde regelmaat leken te vertonen, zeiden zij door te kunnen trekken naar de toekomst. Naar deze aanpak verwezen de toekomstverkenners met de term "(trend) extrapolatie". Zij veronderstelden daarbij dat hoe dichter ontwikkelingen zich bij het heden afspelen, hoe waarschijnlijker

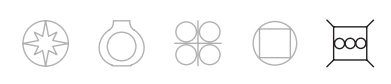


en zekerder uitspraken hierover kunnen zijn en hoe meer voorspelbaar op basis van historische patronen. In het denken over "de toekomst als waarschijnlijkheid" veronderstelden de toekomstverkenners een sterke temporele continuïteit. Dit wil zeggen dat het verleden, heden en toekomst werden beschouwd als onlosmakelijk met elkaar verbonden en gebeurtenissen in verleden, heden en de toekomst als onderdeel van een onomkeerbaar ontwikkelingsproces. Deze interpretatie van de toekomst lijkt in essentie aan te sluiten bij de oude verkenningstraditie en bij het historisch-deterministische repertoire.

De tweede tijdsperiode, van 2020 tot 2040, duidden de toekomstverkenners aan met "de lange termijn" of de "verre toekomst". De toekomstverkenners zeiden over deze termijn te "twijfelen aan ons vermogen om waarschijnlijke ontwikkelingen te onderscheiden". De toekomstverkenners stelden namelijk dat "structuren en mechanismen" op de lange termijn "vervormen" en "plaats (maken, sk) voor nieuwe" (WLO Discussiedocument, 2003). Zij stelden zichzelf daarom tot doel over deze periode vooral "onzekerheden" en "bandbreedtes" te verkennen en verschillende mogelijkheden in beeld te brengen. Over deze tweede tijdshorizon (2020 - 2040) zeiden de toekomstverkenners:

"We laten het gebruikelijke detailniveau in bevolkingsgroepen, bedrijfstakken, regio's en vervoerscategorieën los en verkennen in grote lijnen, spelenderwijs in de vorm van what-if exercities, wat zich in de volgende periode zou kunnen voordoen" (WLO Discussiedocument, 2003).

Voor deze termijn zeiden de toekomstverkenners ervan uit te gaan dat het verleden en heden de toekomst mede vormen en beïnvloeden, maar dat er verschillende mogelijke toekomsten zijn.

Toekomstverkenners suggereerden dat de tijdshorizon bepaalde of zij konden spreken over de toekomst in termen van waarschijnlijkheid of mogelijkheid: een korte termijn zou uitspraken legitimeren in termen van 'waarschijnlijkheid', een lange termijn in termen van 'mogelijkheid'. Zij stelden dat de relatief korte termijn min of meer "realistische" en de lange termijn "minder realistische" uitspraken over de toekomst rechtvaardigde. Zo stelde één van de toekomstverkenners: "Ik vind het wel toelaatbaar om met wat minder empirie en onderbouwing uitspraken te doen over de lange termijn" (Projectbijeenkomst WLO, 19 oktober 2004).

In de WLO-toekomstverkenning stuitten de toekomstverkenners op de vraag of $\mathrm{CO}_{2}$ -afvang en opslag, een techniek die volgens de toekomstverkenners met allerlei maatschappelijke en technische onzekerheden is omgeven, wel of niet in één of meer scenario's meegenomen zou moeten worden. Om, ondanks het bestaan van onzekerheid, toch vaste grond onder de voeten te krijgen en te kunnen bepalen of, en zo ja, hoe deze techniek in de scenario's zou kunnen worden meegenomen, zochten 
de toekomstverkenners naar verschillende analogieën ${ }^{54}$. Eén toekomstverkenner noemde Noorwegen als een voorbeeld waar nu al testprojecten voor $\mathrm{CO}_{2}$-afvang en opslag zijn en verwachtte op basis daarvan dat er in Nederland "over niet al te lange tijd" ook zo'n testproject zal worden gestart. Op basis hiervan betoogde hij om deze techniek in iedere geval in één van de scenario's mee te nemen. Een ander gebruikte in deze discussie een thematische analogie, namelijk door 'genetische modificatie' te beschouwen als "een soort parallel" met $\mathrm{CO}_{2}$-afvang en opslag. Hij stelde voor te kijken naar wat de werkgroep Landbouw doet met genetische modificatie in hun werkgroep: "Als zij genetische modificatie meenemen in het Landbouwscenario, dan zou je kunnen zeggen, 'OK, dan ook $\mathrm{CO}_{2}$-afvang en opslag in het energiescenario'”. Weer een ander gebruikte een analogie van andere energietechnieken, zoals kernenergie, om te beargumenteren waarom $\mathrm{CO}_{2}$-afvang en opslag meegenomen zou moeten worden. Hij zegt hierover: "Ook kernenergie bleek niet beheersbaar te zijn, terwijl het toch werd ingezet" (Projectbijeenkomst WLO, 8 juni 2004). Toekomstverkenners gebruiken dus zogenaamde 'exemplars' 55 of analogieën uit andere tijden en/of andere plaatsen om verhalen te kunnen vertellen over de 'nieuwe tijd'. Door te zoeken naar veronderstelde vergelijkbare gevallen in andere (al dan niet denkbeeldige) tijden of op andere plaatsen, zeggen toekomstverkenners onderbouwde verhalen te kunnen vertellen over de 'nieuwe toekomst'.

Observaties in de praktijk laten echter zien dat de toekomstverkenners deze en andere verhalen die niet direct verankerd kunnen worden in het verleden vaak ter discussie stelden. Zo constateerde een toekomstverkenner over uitspraken over de toekomst van werkgelegenheid:

"Dit wijkt enorm af van de historische trends. We moeten wel uit kunnen leggen waarom de trend verandert. Het is de vraag of we scenariobeelden met die bandbreedte nog voldoende kunnen onderbouwen. Om nu te stellen die laatste 30-40 jaar zijn niet relevant meer, dat lijkt me toch onrealistisch. Hoe verder van de gemiddelde trend wordt afgeweken, hoe minder realistisch het wordt" (Projectbijeenkomst WLO, 23 augustus 2004).

\footnotetext{
${ }^{54}$ Dat toekomstverkenners zoeken naar analogieën om een glimp op te vangen van de 'nieuwe toekomst' wordt beschreven in de literatuur over toekomstverkennen. Armstrong (2001) stelt bijvoorbeeld dat "to make forecasts in new situations, we often try to think of analogies" (zie ook van Notten (2005)).

${ }^{55}$ Deze term is ontleend aan Kuhn (1970). Hij stelde dat elke discipline een eigen cognitief kader heeft, bestaande uit concepten, methoden, data en vocabulaire, van waaruit wetenschappers onderzoek doen. Volgens Kuhn (1970) bestaat zo'n cognitief kader uit drie elementen, namelijk de onderliggende theorie (generalisaties), geïdealiseerde modellen en analogieën en zogenaamde 'exemplars' die dienen als illustraties bij algemene generalisaties. Deze elementen samen zouden individuen binnen een discipline instrueren "to see the same things when confronted with the same stimuli" (Kuhn, 1970: 193-4).
}

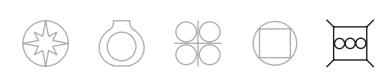


Een ander stelde: "Ik heb moeite hier verhalen over te schrijven die consistent en samenhangend zijn. In mijn optiek beginnen de verhalen dan te wringen" (Projectbijeenkomst WLO, 23 augustus 2004). Ik zag hier dat toekomstverkenners uitspraken over 'andere tijden' tegen de historisch deterministische meetlat gingen leggen. Uitspraken die niet direct terug te voeren zijn op observaties uit het verleden en in het heden werden vaak afgedaan als "te exotisch" en als "science fiction". Dit zag ik ook gebeuren in SCENE waarin de toekomstverkenners stelden:

\begin{abstract}
"Een inventarisatie van de huidige situatie is ook nodig om een relatie te leggen tussen het beeld van het heden en de verschillende denkbare beelden van de toekomst. Dit voorkomt dat de scenario's 'in de lucht komen te hangen' en uitmonden in 'science fiction'" (SCENE Plan van aanpak, 2001: 22).
\end{abstract}

Hoe "plausibel" (d.w.z. een toekomstige mogelijkheid) toekomstverkenners iets achten, wordt steeds meer afhankelijk van de mate waarin die uitspraak verankerd kan worden in het verleden. Terwijl de intentie juist was om los te komen van die historische en huidige structuren en patronen. Dus, hoewel toekomstverkenners historisch deterministische redeneerpatronen legitimeerden voor uitspraken over de eerste termijn (2000-2020), bleef het daar niet toe beperkt. Tijdens de discussies werden dit type redeneringen ook ingezet voor uitspraken die betrekking hadden op de "lange termijn" (2020-2040). Historisch-deterministische redeneerpatronen bleven namelijk niet beperkt tot uitspraken over de eerste termijn, maar werden door sommige toekomstverkenners ook steeds vaker ingezet om de in hun ogen te "exotische" en "onrealistische" uitspraken over de tweede termijn te diskwalificeren. Het historisch-determinisme kreeg dus in het proces van toekomstverkennen steeds meer ruimte.

Andere toekomstverkenners in de WLO-toekomstverkenning, die vast wilden blijven houden aan de ambitie uitspraken te doen over 'nieuwe toekomsten' en het discontinuïteitsperspectief brachten hier tegen in:

\footnotetext{
"Het afwijken van de historische trend betekent niet dat de uitspraken niet realistisch zijn. Waarom moeten nieuwe omstandigheden altijd aansluiten bij bestaande trends? Je moet niet vergeten dat het scenario's zijn. Verhalen over 'wat gebeurt er als...' Je kunt bij wijze van spreken die scenario's nooit van A tot Z uitrekenen. Het is heel moeilijk om via een of andere vergelijking of een of andere statistische analyse keiharde relaties te vinden. Je zult altijd een aantal kwalitatieve keuzes moeten maken in de sfeer van het scenario. We moeten toch beseffen dat we over een periode van maar liefst veertig jaar praten. Daar kan toch heel veel gebeuren" (Projectbijeenkomst WLO, 23 augustus 2004).
}

Voor de termijn 2020-2040 zeiden deze toekomstverkenners het niet waarschijnlijk te achten dat de wereld zal zijn zoals deze in het verleden was en dat, als men uitspraken deed over de toekomst, beter niet gesproken kon worden in termen van 
waarschijnlijkheid, maar van 'mogelijkheid'. Omdat de (verre) toekomst in hun ogen omgeven was met onzekerheid was het volgens hen niet realistisch om geobserveerde ontwikkelingen en gebeurtenissen in het verleden en heden zondermeer te extrapoleren naar de toekomst. Een toekomstverkenner gaf te kennen moeite te hebben met het doortrekken van trends uit het verleden naar de toekomst en vond dat ze "voorzichtig" moesten zijn met redeneringen als "we hebben het in het verleden zo gedaan, dus dat zetten we voort", want "dat het in het verleden zo is gegaan betekent niet dat het in de toekomst ook zo zal gaan" (Projectbijeenkomst WLO, 23 maart 2004). En een ander waarschuwde:

\begin{abstract}
"Extrapoleren kan toch ook een valkuil zijn. Als je 20-30 jaar terug kijkt en je ziet daar een eenduidige relatie tussen twee variabelen die historisch constant blijkt te zijn, dan wil dat nog niet zeggen dat die ook in de toekomst causaal samenhangt. Je mag historische trends niet als vanzelfsprekend doortrekken tot de volgende dertig jaar waarin wellicht dingen veranderen" (Projectbijeenkomst WLO, 24 augustus 2004).
\end{abstract}

Deze toekomstverkenners gingen ervan uit dat er veel ontwikkelingen zijn waarvan niet duidelijk is of, en zo ja welke rol(len), deze zullen spelen in de toekomst en dat ontwikkelingen in heden en verleden daarom niet of in ieder geval niet altijd kunnen worden beschouwd als determinanten voor de toekomst. Zo stelde één van de toekomstverkenners:
"Het is de vraag of je je in de scenario's helemaal moet laten leiden door empirische feiten uit het verleden of niet. De toekomst is nu eenmaal onzeker, dus kunnen we ons beter richten op het verkennen van de bandbreedtes en ons af te vragen of dit ver genoeg gaat of niet" (Projectbijeenkomst WLO, 23 maart 2004).

Een ander beaamde:
"Ja, hoe belangrijk is het om het exact allemaal empirisch onderbouwd te hebben? We zijn scenario's aan het maken. Er zit dus een ontwerpelement in. Wel een ontwerpelement met goed verstand, maar we hoeven niet elke uitspraak empirisch op basis van historisch materiaal te onderbouwen" (Projectbijeenkomst WLO, 23 maart 2004).

In de praktijk van toekomstverkennen zijn dus tegelijkertijd verschillende temporele repertoires actief. Terwijl historisch-deterministische redeneerpatronen steeds meer ruimte kregen, probeerde een aantal toekomstverkenners tegenwicht te bieden. De argumenten van deze toekomstverkenners zijn te kwalificeren als antideterministisch en leken aan te sluiten bij de 'nieuwe' toekomstoriëntatie. Toekomstverkenners gaven, afhankelijk van hun perspectief op de kenbaarheid van de toekomst, een ander antwoord op de vraag 'wat is realistisch?'. Sommige toekomstverkenners mobiliseerden het historisch-deterministisch repertoire en stelden dat de plausibiliteit toeneemt naarmate 
uitspraken over de toekomst sterker verankerd konden worden in het verleden en heden. Zij lieten zich dus primair leiden door observaties uit het verleden en door wat zij op basis daarvan "weten" en "kennen". Zij redeneerden vanuit zekerheden en probeerden, door zich te baseren op ontwikkelingen en trends in verleden en heden, onzekerheden weg te redeneren of tenminste irrelevant te maken. Andere toekomstverkenners mobiliseerden een discontinuïteitrepertoire en stelden hiertegenover dat het juist "niet realistisch" is dat de toekomst zal zijn zoals deze in het verleden was. In tegenstelling tot de eerste groep streefden zij ernaar bestaande patronen en structuren los te laten. Hun startpunt was het "niet weten" en zij zeiden juist niet te willen redeneren vanuit zekerheden van het verleden, maar vanuit onzekerheden over de toekomst. Zij namen, met andere woorden, de onzekerheden over de toekomst als startpunt om van daar uit alternatieve perspectieven te ontwikkelen op hoe de wereld er (mogelijkerwijs) in de toekomst uit zou kunnen zien.

Dat in de praktijk van toekomstverkennen verschillende temporele repertoires naast elkaar bestonden, was aan de oppervlakte echter niet altijd 'zichtbaar'. Dit kwam omdat, hoewel de toekomstverkenners redeneerden vanuit een ander temporeel perspectief, vaak hetzelfde vocabulaire werd ingezet. Hierdoor werd de illusie gewekt dat de toekomstverkenners op hetzelfde spoor zitten. Illustratief is de volgende passage waarin de toekomstverkenners met elkaar discussiëren over de vraag in welke mate de toekomstscenario's van elkaar zouden moeten variëren:

K: $\quad$ "We weten met zijn allen dat we geen trendprognoses willen, maar dat we een zekere bandbreedte willen scheppen".

E: $\quad$ "We moeten natuurlijk wel heel goed kijken wat in het verleden heeft plaatsgevonden en die mechanismen kennen".

A: $\quad$ "Maar jij vindt toch ook dat er variatie moet komen en dat het zinvol is om naar variatie te kijken?'

E: $\quad$ Ja, maar binnen realistische marges. Binnen die realistische marges is wel ruimte voor invulling van verschillende scenario's en voor verandering ten opzichte van wat we in het verleden hebben gezien".

A: "Oké, dan zitten we op dezelfde lijn".

K: $\quad$ "Dus iedereen wil variatie aanbrengen. Ik ga er dus vanuit dat er draagvlak is voor de keuze om de scenario's meer te laten variëren" (WLO 23 augustus 2004).

Op het eerste gezicht lijken deze toekomstverkenners eensgezind: ze willen kijken naar trends in het verleden, maar willen tegelijkertijd wel van historische trends afwijken met het doel "scenario's" te maken met "een zekere bandbreedte" en dus variatie in de set van toekomstbeelden. Hoewel de toekomstverkenners min of meer hetzelfde vocabulaire inzetten, hadden zij fundamenteel andere handelingswijzen voor ogen. Afhankelijk van hun perspectief op de kenbaarheid van de toekomst, legden de toekomstverkenners 
andere verbindingen tussen verleden, heden en toekomst en gaven zij een andere invulling aan wat "realistisch" is. In het historisch-deterministische perspectief werden verleden, heden en toekomst stevig aan elkaar verknoopt ("We moeten natuurlijk wel heel goed kijken wat in het verleden heeft plaatsgevonden en die mechanismen kennen"). In het andere perspectief wordt de toekomst juist 'los' gemaakt van verleden en heden met als bedoeling inzicht te krijgen in "nieuwe" en "andere" tijden ("We weten met zijn allen dat we geen trendprognoses willen, maar dat we een zekere bandbreedte willen schappen" en "Maar jij vindt toch ook dat er variatie moet komen en dat het zinvol is om naar variatie te kijken"). Op de grenzen van het weten ontstaat dus strijd over de manier waarop met onzekerheden moet worden omgegaan.

Afhankelijk van het perspectief dat de toekomstverkenners hadden gaven zij ook een andere invulling aan termen als "variatie", "scenario's", "bandbreedte" en "verandering". Vanuit een historisch deterministisch perspectief betekent verandering het extrapoleren van geconstateerde verandering in het verleden. Deze toekomstverkenners achtten verandering alleen "realistisch" als tegelijkertijd een zekere mate van continuïteit met het verleden wordt verondersteld. Zij wilden verandering in hun analyses wel meenemen, maar alleen in de "intensiteit zoals deze in het verleden was" 56 . Zo stelde één van de toekomstverkenners: "Als een trend gaat verschuiven, dan wil je wel een historische periode hebben waar die trend op aansluit" (Projectbijeenkomst WLO, 11 mei 2005). In het discontinuïteitrepertoire betekent verandering het verkennen van nieuwe (mogelijke) nieuwe toekomstige patronen en structuren. Deze toekomstverkenners zijn niet zozeer geïnteresseerd in de historisch gefundeerde bandbreedtes, maar willen juist zeer verschillende perspectieven op hoe de wereld is en in de toekomst mogelijkerwijs kan zijn in beeld brengen. De scenario's moeten dus fundamentaal van elkaar verschillen en aansluiting op historische ontwikkelingen is geen voorwaarde. De scenario's mogen dus juist ook verschillen ten opzichte van het verleden. Dus, afhankelijk van het perspectief op de kenbaarheid van de toekomst krijgen centrale begrippen als "scenario's", "verandering", "variatie" en "bandbreedte" een andere connotatie (zie tabel 5.1).

Door het niet erkennen van deze verschillende temporele repertoires en het veronderstellen van een consensus die er niet was (en niet kon zijn gezien het naast elkaar bestaan van verschillende temporele perspectieven) kwamen tijdens het hele verkenningsproces gemaakte afspraken ter discussie te staan en werden compromissen steeds weer opengebroken. De bereikte consensus bleek een illusie te zijn. De toekomstverkenners leken zich vaak niet bewust van het bestaan van deze fundamenteel verschillende temporele perspectieven dachten "op dezelfde lijn" te zitten. Door de suggestie van "concerted action and perception" (Collins, 1985), dat wil zeggen het veronderstellen van consensus die er niet is, en het niet erkennen van deze multipliciteit,

\footnotetext{
56 In de toekomstverkenningsliteratuur wordt naar deze aanpak verwezen met de termen als "onveranderde verandering" (Bell, 2000: 250).
}

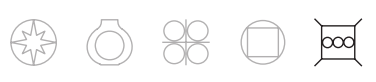


krijgt het 'oude' repertoire steeds meer ruimte. Doordat toekomstverkenners de illusie van "concerted action and perception" in stand hielden, bleven de verschillende repertoires, de spanningen tussen, en de spanning met, de gestelde ambities buiten beeld. En hierdoor wordt het verkennen vanuit de 'nieuwe' ambitie niet alleen problematisch, maar, zoals ik in de volgende paragraaf zal laten zien, zelfs onmogelijk.

\begin{tabular}{|c|c|c|}
\hline & $\begin{array}{l}\text { Historisch-deterministisch } \\
\text { repertoire }\end{array}$ & Discontinuïteitsrepertoire \\
\hline Uitgangspunt & $\begin{array}{l}\text { - Zekerheden van het verleden } \\
\text { - Waarschijnlijkheid } \\
\text { - Temporele continuïteit staat } \\
\text { centraal }\end{array}$ & $\begin{array}{l}\text { - Onzekerheden van de toekomst } \\
\text { - Mogelijkheid } \\
\text { - Afwijken van de huidige situatie } \\
\text { staat centraal }\end{array}$ \\
\hline \multicolumn{3}{|l|}{ Vocabulaire } \\
\hline Scenario's & $\begin{array}{l}\text { - Historisch-gefundeerde, } \\
\text { geëxtrapoleerde verhalen } \\
\text { over de toekomst }\end{array}$ & $\begin{array}{l}\text { Verhalen over de toekomst die } \\
\text { anders zijn dan het verleden en } \\
\text { heden }\end{array}$ \\
\hline Verandering & $\begin{array}{l}\text { - Extrapoleren (in de mate en } \\
\text { intensiteit zoals deze in het } \\
\text { verleden was) }\end{array}$ & $\begin{array}{l}\text { - Verkennen van nieuwe } \\
\text { toekomstige patronen en } \\
\text { structuren }\end{array}$ \\
\hline Variatie & $\begin{array}{l}\text { - Historisch gefundeerd, } \\
\text { minimale differentiatie }\end{array}$ & $\begin{array}{l}\text { - Fundamenteel verschillende } \\
\text { perspectieven op de toekomst }\end{array}$ \\
\hline Bandbreedte & $\begin{array}{l}\text { - Een "waarschijnlijk" } \\
\text { toekomstbeeld met eventueel } \\
\text { (een) hoge en (een) lage } \\
\text { variant(en) }\end{array}$ & $\begin{array}{l}\text { • "Mogelijke" toekomsten die } \\
\text { wezenlijk andere richtingen } \\
\text { uitwijzen }\end{array}$ \\
\hline Handelingswijze & $\begin{array}{l}\text { - Uitspraken over de toekomst } \\
\text { verankeren in verleden en } \\
\text { heden (extrapoleren) } \\
\text { - Weinig ruimte voor } \\
\text { 'out-of-the-box' denken }\end{array}$ & $\begin{array}{l}\text { - Historische en huidige } \\
\text { structuren en patronen (deels) } \\
\text { loslaten } \\
\text { - O.b.v. onzekerheden } \\
\text { verschillende toekomsten } \\
\text { bedenken }\end{array}$ \\
\hline
\end{tabular}




\subsection{Het historisch-determinisme wordt dominant}

Er zijn situaties denkbaar waarin verschillende repertoires probleemloos naast elkaar kunnen bestaan ${ }^{57}$. In de door mij geobserveerde praktijk was dat zeker niet het geval en bleken de verschillende repertoires met elkaar (vaak onderhuids) te conflicteren (zie ook van Lente (1993; 2000); Bijker (1995); van Eeten (1999) en Mesman (2002)). Kijkend door de lens van temporele repertoires, lijkt dit niet alleen het geval te zijn in WLO, maar bleek dit ook in SCENE en WVR een rol te spelen. In de door mij bestudeerde praktijken van toekomstverkennen zag ik steeds conflicten ontstaan tussen enerzijds toekomstverkenners die de toekomst op historisch-deterministische wijze willen verkennen en anderzijds toekomstverkenners die historische structuren en patronen juist (deels) los willen laten en aansluiting blijven zoeken bij de nieuwe toekomstoriëntatie. De problemen die ik heb beschreven bij het realiseren van de variatie- en integratieambitie zouden hiermee samen kunnen hangen.

Het lijkt erop dat, doordat de fundamentele verschillen tussen verschillende repertoires en de tegenstrijdigheden tussen historisch deterministische redeneerpatronen en de 'nieuwe' verkenningsambitie niet werden herkend, het historisch deterministisch perspectief vrij spel kreeg. In de loop van het WLO-project begon een aantal toekomstverkenners steeds nadrukkelijker alle pogingen om vanuit de 'nieuwe' ambitie de toekomst te verkennen onder vuur te leggen. Zij deden dit door tijdens de discussies uitspraken die niet direct verankerd konden worden in observaties in verleden en heden tegen de historisch deterministische meetlat te leggen. Zo stelde een toekomstverkenner:

\footnotetext{
"Waar baseer je dat op? Heb je een historische trend waar dat bij aansluit? Je moet wel uit kunnen leggen waarom die trend verandert. Anders baseer je je op drijfzand" (Projectbijeenkomst WLO, 23 augustus 2004).
}

Om te komen tot uitspraken over de toekomst zeiden deze toekomstverkenners zich te willen baseren op waargenomen trends en ontwikkelingen in het verleden en heden. Zo stelde één van hen bijvoorbeeld:

\footnotetext{
"In het verleden, over een periode van veertig jaar, is altijd sprake geweest van binnenlandse migratie. Dat is voor mij een trein die doorrolt. Ik ga uit van ervaringen uit het verleden. Als dat blijkbaar de afgelopen jaren zo is gegaan, dan trek ik die ervaring door. Dat zij keiharde dingen, dus dat gebeurt gewoon. Het is onvermijdelijk, want dat zien we nu al gebeuren" (Projectbijeenkomst WLO, 23 maart 2004).
}

Deze toekomstverkenners stelden dat het onmogelijk is om in de toekomst te kijken,

\footnotetext{
${ }^{57}$ Bijker (1995) stelt bijvoorbeeld dat "when elements of the (..) frames are not contradictory, the different repertoires will continue to exist together" (143)
}

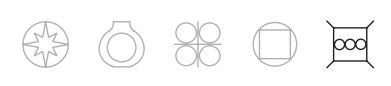


maar dat ze wel kunnen "kijken naar de historische trends en dan zie je wat er is gebeurd de laatste dertig jaar" en dus "hoe de toekomst waarschijnlijkerwijs zal zijn" (Projectbijeenkomst WLO, 23 augustus 2004).

In WLO bleken de pogingen uitspraken die niet direct gerelateerd konden worden aan observaties in verleden en heden te diskwalificeren zeer effectief. Er lijkt daarmee sprake te zijn van een paradox. Want, om zich staande te houden in onzekerheid en complexiteit, is de verleiding groot om vast te houden aan "het zekere", "het weten" en "het kennen", terwijl diezelfde onzekerheid en complexiteit voor toekomstverkenners juist aanleiding was om zekerheden los te laten en aan toekomstverkenning te doen. Toekomstverkenners gleden, met het verstrijken van de tijd, steeds verder weg van de 'nieuwe' toekomstoriëntatie. Daarbij vielen ze terug in de 'bekende' realistische redeneerpatronen en gingen handelen volgens het historisch-deterministische devies: "be conservative when the situation is uncertain" (Armstrong, 2001: 229). Pogingen om "nieuwe" toekomsten te verkennen werden keer op keer verijdeld door historisch-deterministische bezwaren die steeds sterken gingen klinken en meer 'anklang' kregen. Hierdoor leek de balans steeds verder door te schieten naar beschrijvingen van (quasi) realistische toekomsten waarin onzekerheid, variatie en discontinuïteit werden weggeredeneerd. Het resultaat was dat de toekomstverkenners uiteindelijk moesten constateren dat de scenario's die zij hadden ontwikkeld maar zeer beperkt varieerden en dat zij er niet aan toe waren gekomen om bijvoorbeeld de effecten van een aantal "exogene schokken" te doordenken en analyseren (WLO discussiedocument, 2003). Het onderscheid tussen de verschillende tijdshorizonnen vervaagde uiteindelijk: het historisch-determinisme wat op de agenda kwam voor 20002020 werd uiteindelijk ook het leidende perspectief voor 2000-2040. In WLO zag ik dat "het niet weten" en het "verkennen" steeds vaker het onderspit delfde van het "wel weten" en het "kennen" en dat de 'nieuwe' ambities die toekomstverkenners hadden (dus het verkennen van "mogelijke" en "nieuwe" toekomsten) in het geding kwamen. Hoewel alle toekomstverkenners het starten van hun toekomstverkenning legitimeerden door te wijzen op de onzekerheden waarmee het verkennen van de toekomst is omgeven en in het plan van aanpak expliciet aandacht vroegen voor het doordenken van "nieuwe" en "andere" toekomsten kwamen pogingen om het "niet weten" te erkennen en een plek te geven in de toekomstverkenning steeds meer onder vuur te liggen en werden zij keer op keer 'onschadelijk' gemaakt.

Als ik terugkijk naar SCENE en WR vanuit deze tweede orde analyse, dan kan ook in deze projecten het onderscheid worden gemaakt tussen enerzijds historisch deterministisch getinte perspectieven op verleden, heden en toekomst en anderzijds perspectieven waarin het deterministisch denken wordt doorbroken.

In WR manifesteerde het bestaan van verschillende perspectieven zich op het grensgebied tussen onderzoek en ontwerp. Onderzoekers baseerden hun uitspraken over de (waarschijnlijke) toekomst in de regel op waargenomen trends in heden en 
verleden; ontwerpers op mogelijke toekomsten. De toekomstverkenners stelden dat ontwerp aan andere eisen mocht of zelf moest voldoen dan onderzoek, waarbij ontwerp werd geassocieerd met "verbeelding" en "inspiratie" en moest voldoen aan criteria als "creativiteit", "innovatie" en "generaliseerbaarheid". Onderzoek daarentegen moest voldoen aan criteria als "consistentie", "wetenschappelijke onderbouwing", "nuance" en "detail". Tijdens de discussies hielden de onderzoekers steeds alle pogingen om 'nieuwe' toekomsten te verbeelden tegen het 'onderzoekslicht' en zij diskwalificeerden alles wat niet kon worden verankerd in verleden en heden. Op deze manier werden de ontwerpers, die los wilde komen van historisch-deterministische redeneerpatronen, buitenspel gezet en 'verdween' het ontwerp uiteindelijk zo goed als uit de toekomstverkenning, waardoor de WR uiteindelijk een onderzoeksverkenning werd. Het falen van de integratieambitie lijkt dus het resultaat van het conflicteren van verschillende temporele repertoires, waarbij onderzoekers (die in dit geval veelal een historisch deterministisch perspectief aanhingen) in een 'betere' positie verkeerden dan de ontwerpers.

Door het dominant worden van historisch deterministische redeneerpatronen in WR en WLO ontstond een spanning tussen de ambities die toekomstverkenners hadden en de manier waarop de toekomst uiteindelijk werd verkend. En van hieruit gezien is het niet verwonderlijk dat de toekomstverkenners er niet is slagen de 'nieuwe' ambities te realiseren.

In SCENE was het naast elkaar bestaan, conflicteren en concurreren van verschillende temporele repertoires minder manifest. Wel kan worden beargumenteerd dat de skeletbenadering van het assenstelsel historisch-deterministische wortels heeft en het historische determinisme op deze manier ook een rol speelde in het SCENE-project. In deze functionele betekenis en de manier waarop het assenstelsel wordt neergezet in de scenariohandboeken is het uitgangspunt dat toekomstverkenners licht kunnen werpen op de toekomst door een beter begrip van de "fundamentele" krachten die het toekomstige verloop van het systeem sturen en op deze manier 'determineren'. In SCENE constateerde ik dat, hoewel toekomstverkenners tijdens het proces van toekomstverkennen niet vast konden blijven houden aan de skeletbenadering van het assenstelsel (zoals dat wordt beschreven in de scenariohandboeken), omdat het niet mogelijk bleek te zijn twee belangrijkste drijvende krachten te 'ontdekken', bleef het skeletideaal gedurende het hele project actief.

In de praktijk bleken echter vooral aanhangers van de fundering- en bouwstellingsbenadering met elkaar te concurreren: de twee benaderingen die het meest in lijn waren met de 'nieuwe' ambitie. De skeletbenadering, waaraan een historischdeterministische insteek leek te kleven en dus op gespannen voet staat met de 'nieuwe' ambitie, was het minst dominante repertoire. Het beschouwen van de discussies rondom het gebruik van het assenstelsel door een 'tijdslens' lijkt dus te kunnen verklaren waarom

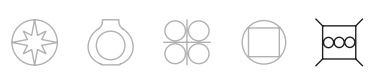


er in de productiefase van SCENE wel allerlei moeizame spanningen optraden, maar geen problematische tegenstrijdigheden (en wat wel het geval was in WVR en WLO).

In hoofdstuk drie en vier heb ik laten zien dat toekomstverkenners vaak terugvallen op historisch-deterministische redeneerpatronen en in dit hoofdstuk hoe ze dat doen. Dit onderzoek biedt onvoldoende inzichten om te kunnen verklaren waarom het historischdeterministische repertoire, alle bedoelingen ten spijt, vaak aan terrein wint in de praktijk van toekomstverkennen. Het is niet mogelijk om op basis van mijn onderzoek een ultieme verklaring te geven. Wel lijkt het zo te zijn dat als je als toekomstverkenner niet reflecteert op je object van onderzoek (tijd, de toekomst) je het risico loopt weg te glijden in het 'oude bekende' en te vervallen in 'veilige' historisch-deterministische redeneerpatronen. En als de toekomst eenmaal is beschreven in termen van 'waarschijnlijkheid', dan is het heel moeilijk gebleken hier nog los van komen en de gecreerde toekomstbeelden alsnog vragenderwijs of probleemstellend te benaderen. Zelfs als, zoals in VVR, het ontwerpend denken expliciet onderdeel is van de toekomstverkenning, lijken methoden ontoereikend om toekomstverkenners los te weken uit hun historisch-deterministische denkkaders en te gaan denken in termen van 'mogelijkheid' en 'veranderlijkheid'.

\subsection{Toekomstverkenningen in een 'nieuw' jasje}

Hoewel de toekomstverkenners tijdens de "definitiefase" van de toekomstverkenning het bestaan van onzekerheid en complexiteit mobiliseerden als startpunt van hun toekomstverkenningen, gingen zij in de loop van de tijd de onzekerheden steeds meer mijden. In de praktijk betekende dit dat, hoewel de toekomstverkenners zich voornamen in de officiële documentatie niet alleen te denken over 'waarschijnlijke', maar ook 'mogelijke' én 'nieuwe' toekomsten, zij steeds meer spraken in termen van 'waarschijnlijkheid'. Dit is ook de observatie van Dobbinga (2001) die onderzoek deed naar toekomstverkenners bij het Ministerie van Verkeer en Waterstaat. Zij stelt:

"De teamleden stelden zich in het begin open voor het onbekende. Dit werd als een hoge waarde ervaren. In de looptijd van het project ging het team onzekerheid ten aanzien van het onbekende mijden" (56).

Tijdens het verkennen van de toekomst (de "productiefase") wordt een temporeel repertoire dat past bij de 'oude' generatie toekomstverkenningen actief en in WR en WLO zelfs dominant. Toekomstverkenners keren dus, bewust of onbewust, terug naar wat ze eigenlijk wilden ontvluchten.

In de laatste fase van de toekomstverkenning, wat ik de "presentatiefase" zal noemen, werden de 'nieuwe' ambities wel weer nadrukkelijk gemobiliseerd. In hoofdstuk 3 heb 


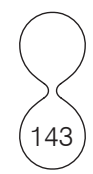

ik bijvoorbeeld laten zien dat het assenstelsel, dat was ingezet om de variatieambitie te realiseren, werd "weggegooid" en dat er in het eindrapport niet meer (expliciet) naar werd verwezen, omdat deze in strijd zou zijn met de ambitie geïntegreerde scenario's te ontwikkelen. En in hoofdstuk 4 heb ik laten zien dat de toekomstverkenners de integratieambities verlieten, maar vervolgens in de presentatie de variatieambitie mobiliseerden in lijn met de 'nieuwe' toekomstoriëntatie. Op het moment van schrijven was het WLO-rapport nog niet gepubliceerd, maar mijn verwachting is dat zij, zeker gezien hun oorspronkelijke ambities, het historisch deterministisch perspectief niet prominent op de voorgrond zullen plaatsen.

In de presentatie van wat zij gedaan hebben lijken toekomstverkenners dus hun toekomstverkenningen wel weer nadrukkelijk te positioneren als onderdeel van een nieuwe toekomstoriëntatie. En dit terwijl in de dagelijkse praktijk van toekomstverkennen het 'oude' repertoire een rol bleef spelen in WR en WLO en steeds dominanter werd. Observaties in de praktijk lijken dus te duiden op een onderscheid tussen wat Goffman (1959) heeft aangeduid met "frontstage" en "backstage"58. In zijn boek The Presentation of Self in Everyday Life bestudeerde hij menselijk gedrag in de omgang met anderen en de manieren waarop mensen zich naar buiten toe presenteren. "Backstage" verwijst naar het interne functioneren en "frontstage" naar de manieren waarop mensen zich naar buiten toe presenteren. Ook toekomstverkenners lijken 'frontstage' en 'backstage' verschillend te functioneren en waarbij de toekomstverkenning en de geproduceerde toekomstkennis op een fundamenteel andere manier worden gepositioneerd.

Ik ben niet de eerste die het onderscheid tussen "frontstage" en "backstage" mobiliseert om het functioneren van professionele groepen/organisaties te duiden. Hilgartner (2000) en Bal, Bijker, \& Hendriks (2002) gebruikten de theatermetafoor van Goffman om institutionele en professionele autoriteit te begrijpen. Zij laten zien hoe professionele groepen samenwerken in het in stand houden van een "front" naar hun cliënten en hun publiek. Dobbinga (2001) maakt in haar analyse van de manieren waarop toekomstverkenners in het Questa-project betekenis geven aan de scenariomethode als managementinstrument een onderscheid tussen hoe toekomstverkenners "achter de coulissen" werken met scenario's en hoe zij dit werken met scenario's "op het podium" presenteren.

Bal, Bijker, \& Hendriks (2002) die onderzoek deden naar de mechanismen en patronen in de praktijk van wetenschappelijke advisering van de Gezondheidsraad beschrijven de verschillende manieren waarop de Raad intern en extern functioneert in termen van een "paradox model". "Frontstage" zou de Raad wetenschap presenteren in 'positivistische' termen, en "backstage" zou een 'constructivistisch' wereldbeeld dominant zijn. In

\footnotetext{
${ }^{58}$ Hilgartner (2000), Dobbinga (2001) en Bal, Bijker, \& Hendriks (2002) hebben dit model toegepast op beleidsadviserende praktijken.
}

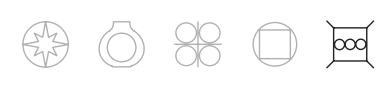


dit model onttrekken actoren het "backstage" handelen uit het gezichtsveld om het handelen naar buiten toe mogelijk te maken en de buitenwereld te kunnen overtuigen van wetenschappelijke autoriteit.

Het mobiliseren van een nieuwe ambitie (in SCENE werd schakelden de toekomstverkenners van de variatieambitie naar de integratieambitie en in WR werd de integratieambitie vervangen door een variatieambitie) kan worden begrepen als een poging van de toekomstverkenners om het "paradoxspel" te spelen. Backstage kenmerkte zich, ondanks de 'nieuwe' ambities', door het activeren van, en in WVR en WLO zelfs dominant laten worden van, historisch-deterministische repertoires (en het marginaliseren van repertoires die juist wel beantwoorden aan die nieuwe toekomstoriëntatie). Frontstage positioneerden zij de toekomstverkenning en het (beoogde) resultaat daarvan nadrukkelijk als onderdeel van de nieuwe toekomstoriëntatie. Het schakelen van toekomstverkenners tussen de integratie- en variatieambitie kan dan worden begrepen als een strategie om, ondanks de dreigende impasse bij het realiseren van de variatieambitie en het falen van de integratieambitie, toch nog te kunnen blijven appelleren aan de 'nieuwe' toekomstoriëntatie. In de uiteindelijke presentatie probeerden de toekomstverkenners tegenstrijdigheden tussen de ambities die het startpunt waren van de toekomstverkenning en de dagelijkse praktijk zo goed mogelijk weg te poetsen.

In de door mij geobserveerde praktijk van toekomstverkennen speelden toekomstverkenners dus als het ware een omgekeerd paradoxspel. In tegenstelling tot de beschrijving van Bal, Bijker, \& Hendriks (2002) beantwoordt het proces van toekomstverkenning meer aan een positivistisch wereldbeeld, waarin "het weten" en het baseren van uitspraken in waarnemingsfeiten steeds centraler komen te staan. Aan de andere kant presenteren toekomstverkenners frontstage hun toekomstverkenning en de door hun geproduceerde toekomstkennis voornamelijk in 'constructivistische' termen. In de definitie- en presentatiefase benadrukken toekomstverkenners het "niet weten" en de onzekerheid en complexiteit waarmee het verkennen van de toekomst is omgeven.

Hoewel Dobbinga (2001) het functioneren van toekomstverkenners in het Questa-project niet beschrijft in termen van een "paradoxspel" kan op basis van haar beschrijving ook in die toekomstverkennende praktijk het interne functioneren van toekomstverkenners worden gekarakteriseerd als een omgekeerd paradoxspel. In haar proefschrift beschrijft zij namelijk hoe deze toekomstverkenners zich 'in de coulissen' "nauwelijks onzeker" voelden over "de grens van het nagenoeg ondenkbare", terwijl 'op het podium' "werd gesteld dat het besef van onzekerheid ten aanzien van de toekomst manifest is geworden" (113-4). Hoewel het in mijn onderzoek niet ging om de onzekerheidsbeleving van toekomstverkenners, lijkt er wel een parallel te zijn tussen de manieren waarop toekomstverkenners in de Questa- en de RPB-praktijk van toekomstverkennen frontstage en backstage omgaan met onzekerheid en het "niet weten". 


\subsection{Samenvatting}

Ik begon dit hoofdstuk met de vraag waarom het zo moeilijk blijkt te zijn de 'nieuwe' verkenningsambities te realiseren. Ik heb laten zien dat er meerdere functionele betekenissen aan een veel gebruikte techniek, het zogenaamde assenstelsel, worden toegekend en waartoe deze pluraliteit in de praktijk leidt (hoofdstuk 3). Ook heb ik laten zien dat er allerlei spanningen en tegenstrijdigheden kunnen optreden in de praktijk van toekomstverkennen, die het realiseren van de 'nieuwe' zeer moeilijk of zelfs onmogelijk maakt (hoofdstuk 4). In dit hoofdstuk heb ik laten zien dat er sprake is van een dieper liggend probleem dat te maken heeft met het naast elkaar bestaan van verschillende perspectieven ten aanzien van het object van onderzoek, namelijk 'tijd' en de 'toekomst'. Door te reflecteren op de grondslagen van toekomstverkennen en de manier waarop toekomstverkenners omgaan met 'tijd' heb ik geprobeerd het optreden van de spanningen en tegenstrijdigheden met betrekking tot het realiseren van de integratie- en variatieambities nader te duiden.

Ik heb laten zien dat de manier waarop toekomstverkenners betekenis geven aan tijd nauwelijks wordt benoemd en daarmee vaak impliciet blijt. De manier waarop toekomstverkenners wel uiting geven aan 'tijd' en 'de toekomst' was door het stellen van een tijdshorizon. Achter de manier waarop toekomstverkenners betekenis geven aan 'de toekomst' blijken echter verschillende temporele repertoires schuil te gaan. Ik onderscheidde twee verschillende repertoires waarin verleden, heden en toekomst op een fundamenteel andere manier werden verknoopt. Enerzijds was dat een historisch deterministisch perspectief, waarin de toekomst wordt beschouwd als een logische uitkomst van patronen en causale relaties die in het verleden en heden kunnen worden geobserveerd. Toekomstverkenning is dan het doortrekken van ontwikkelingen in heden en verleden naar de toekomst. De toekomstbeelden werden dus gedetermineerd door de kennis over het verleden en heden, wat in lijn is met de 'oude' verkenningstraditie. In het andere perspectief wordt het denken in continuïteiten doorbroken en gaan toekomstverkenners ervan uit dat de toekomst ook anders zou kunnen zijn. Dit perspectief sluit wel aan bij de 'nieuwe' toekomstoriëntatie. Mijn onderzoek laat zien dat het naast elkaar bestaan van deze verschillende temporele repertoires niet zonder gevolgen was. In SCENE leek het blijven concurreren en conflicteren van verschillende perspectieven uit te monden in een impasse. In WVR en WLO leek de wisselwerking tussen die twee repertoires ertoe te leiden dat het historisch-deterministische repertoire, dat juist op gespannen voet staat met de integratie- en variatieambities, dominant werd, waardoor het moeilijk, zo niet onmogelijk werd voor toekomstverkenners om de 'nieuwe' ambities te realiseren. De spanningen en tegenstrijdigheden blijken dus geworteld te zijn in het naast elkaar bestaan, conflicteren en concurreren van verschillende perspectieven op heden, verleden en de toekomst. En omdat toekomstverkenners deze temporele repertoires niet erkennen en door het historisch-deterministisch repertoire verleid worden, maken zij zelf het realiseren van de 'nieuwe' ambities een 'mission impossible'.

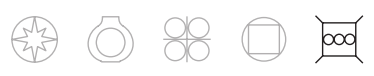


Vervolgens heb ik laten zien dat toekomstverkenners deze problemen opvingen door te schakelen tussen de integratie- en variatieambitie en door de toekomstverkenning "frontstage" anders te presenteren dan de "backstage" praktijk. Opmerkelijk aan deze paradox van toekomstverkenning was dat het beeld dat frontstage neergezet wordt constructivistisch van karakter is, terwijl de praktijk meer positivistische werkwijzen liet zien. 
S147)

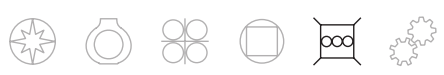



( 34
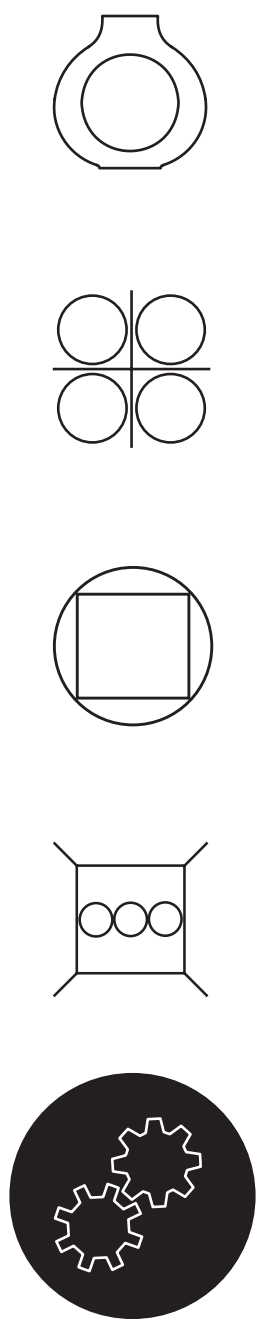


\section{6) Productie van toekomstkennis}

Dit proefschrift begon met de vraag 'hoe produceren toekomstverkenners kennis over de toekomst?'. Het opzetten van die bril hielp mij bij het maken van een eerste ordening van de heterogene onderzoeksdata. Zo richtte ik mijn blik bijvoorbeeld niet op de 'nut-ennoodzaak'-discussie van toekomstverkenning of op de rol die toekomstkennis speelt in het beleidsproces, maar op de manier waarop toekomstverkenners de facto de toekomst verkennen.

De algemene vraag waarmee ik dit onderzoek begon, riep een groot aantal nieuwe vragen op zoals: Hoe vinden toekomstverkenners een balans tussen kennen met relatieve zekerheid en verkennen in totale onzekerheid? Hoe creëren toekomstverkenners orde in complexiteit? Hoe brengen zij structuur aan? Hoe vinden toekomstverkenners houvast terwijl richtlijnen, stappenplannen en routine lijken te ontbreken? Hoe gaan ze om met het bestaan van verschillende perspectieven, deelresultaten en inzichten en hoe integreren zij deze in een gezamenlijk product?

Werkenderweg werden mijn onderzoeksvragen specifieker en versmolten de vragen waarmee ik dit onderzoek was begonnen tot een tweetal thema's waarbinnen ik de gedocumenteerde fragmenten uit verschillende toekomstverkenningen in samenhang kon bespreken en analyseren, namelijk de integratie- en variatieambities. In mijn geval kwamen deze thema's voort uit verwondering over ogenschijnlijke tegenstrijdigheden tussen de ambities die toekomstverkenners zichzelf voorafgaand aan en tijdens het verkennen van de toekomst stelden, en het handelen van diezelfde toekomstverkenners in de praktijk. Hoe komen deze 'nieuwe' verkenningsambities tot uitdrukking in de praktijk van toekomstverkennen? Op welke manier worden deze ambities in de praktijk vormgegeven? Wat betekenen deze ambities voor de manier waarop kennis over de toekomst wordt geproduceerd en gecommuniceerd?

In dit laatste hoofdstuk ga ik terug naar mijn oorspronkelijke onderzoeksvragen en beschrijf ik de inzichten die dit onderzoek heeft opgeleverd over de manier(en) waarop toekomstkennis wordt geproduceerd.

\subsection{Ambities in de praktijk}

De toekomstverkenners die ik de afgelopen jaren volgde, claimden de toekomst te verkennen vanuit een nieuwe toekomstoriëntatie, namelijk vanuit het besef dat er onzekerheid besloten ligt in uitspraken over de toekomst en dat, vanwege complexiteit, kennis van de toekomst per definitie partieel en nooit objectief zeker kan zijn. De plannen van aanpak en andere startdocumenten die door de toekomstverkenners werden geschreven waren doorspekt van dit vocabulaire. In de beginfase waren de 'oude' ambities, waaronder het willen voorspellen van de toekomst, alleen 
aanwezig als voorbeeld van wat toekomstverkenners in hun toekomstverkenning niet ambieerden. In deze fase zeiden toekomstverkenners open te staan voor onzekerheden en 'het onbekende'. Deze toekomstoriëntatie was geen specifieke oriëntatie van toekomstverkenners bij het RPB, maar was ook terug te vinden bij andere beleidsgerichte toekomstverkenningen.

Het besef dat de toekomst is omgeven met onzekerheid vertaalden toekomstverkenners in de praktijk naar wat ik noemde de 'variatieambitie'. De toekomstverkenners probeerden in hun toekomstverkenningen - om recht te doen aan onzekerheid - verschillende perspectieven op de toekomst te doordenken. Het besef dat de hedendaagse samenleving complexer is dan ooit tevoren vertaalden de toekomstverkenners naar de ambitie verschillende thema's, disciplines en perspectieven te integreren. Dit noemde ik de 'integratieambitie'. Toekomstverkenners zeiden niet te willen richten op het voorspellen van de toekomst, maar op het inzichtelijk en beter hanteerbaar maken van onzekerheden en complexiteit waarmee de toekomst is omgeven.

De manieren waarop toekomstverkenners hun ambities probeerden te realiseren en hoe in dit proces van toekomstverkennen toekomstkennis werd geproduceerd, duidde ik in dit proefschrift aan de hand van de volgende concepten en thema's, namelijk:

- Temporele repertoires

- Functionele betekenissen

- Grensoverschrijdende objecten en transformatie van het grensgebied

- Importantie van het historisch-deterministische repertoire en schakelen tussen ambities

- Het paradoxspel van toekomstverkenners

\section{Temporele repertoires}

Mijn observaties in de praktijk laten zien dat in de praktijk van toekomstverkenning verschillende temporele repertoires naast elkaar kunnen bestaan. Enerzijds is dit het historisch-deterministische repertoire, waarin uitspraken over de toekomst worden verankerd in verleden en heden. Anderzijds is dit het discontinuïteitsrepertoire, waarin de toekomst min of meer wordt losgemaakt van het verleden en heden.

Beide repertoires zijn manifestaties van twee fundamenteel verschillende perspectieven op 'tijd' en de manieren waarop verleden, heden en de toekomst aan elkaar kunnen worden verknoopt. In het ene perspectief beschouwen toekomstverkenners de toekomst als een logische uitkomst van eenduidige relaties die in het verleden en heden kunnen worden geobserveerd en kunnen worden doorgetrokken naar de toekomst. De toekomstverkenners die dit repertoire hanteren, gaan vooral uit van de zekerheden

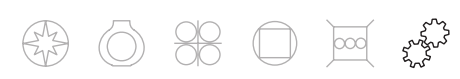


van het verleden en heden en beschouwen ontwikkelingen in het verleden en heden als richtinggevend en bepalend voor de toekomst. Zij spreken dan ook voornamelijk over de toekomst in termen van "waarschijnlijkheid". In het andere perspectief gaan toekomstverkenners ervan uit dat het enige dat we weten over de toekomst is dat de toekomst anders zal zijn dan het verleden en heden. Dergelijke toekomstverkenners gaan, met andere woorden, vooral uit van de onzekerheden van de toekomst en zeggen zich vooral te richten op het afwijken van de huidige situatie. Zij spreken dan ook meestal niet in termen van waarschijnlijkheid, maar van "mogelijkheid". Beide perspectieven staan dus voor een fundamenteel ander gebruik van kennis over verleden en heden. Vanuit het historisch-deterministische perspectief gebruiken toekomstverkenners kennis over het verleden en heden als richtinggevend kader voor het doen van uitspraken over de 'waarschijnlijke' toekomst. Vanuit het discontinuïteitsperspectief is de toekomst min of meer 'open' en kan kennis over verleden en heden worden gebruikt als inspiratiebron voor het doen van uitspraken over 'mogelijke' toekomsten.

Beide temporele perspectieven staan voor twee fundamenteel andere ideeën over hoe de toekomst zou kunnen en moet worden verkend. Dit bleek bijvoorbeeld uit de manier waarop verschillende toekomstverkenners invulling geven aan centrale noties in toekomstverkenning, zoals "scenario", "verandering", "variatie" en "bandbreedte". Daarnaast bestaan er verschillende ideeën over wat een toekomstverkenner zou moeten doen (zie tabel 5.1).

Beide perspectieven zijn incommensurabel en, gezien hun fundamenteel verschillende uitgangspunten, praktisch onverenigbaar. De toekomstverkenners bij het RPB positioneerden zich expliciet in een 'nieuwe' traditie van toekomstverkennen. Daarmee suggereerden zij dat zij het historisch-deterministische denken zouden loslaten en dat zij in hun praktijk voornamelijk vanuit een discontinuïteitsperspectief zouden verkennen. En dit zou betekenen dat zij niet langer uitsluitend zouden blijven redeneren vanuit temporele continuïteit, maar ook, en vooral, aandacht hebben voor discontinuïteiten, verrassingen en onzekerheden en daarmee voor het nieuwe, het andere en nog niet gekende.

In elk van de drie toekomstverkenningen (SCENE, WVR en WLO) waren de 'nieuwe' ambities het startpunt. In SCENE zetten de toekomstverkenners in op de variatieambitie, in WR op de integratieambitie en in WLO op zowel integratie als variatie. De verwachting was daarom dat het discontinuïteitsrepertoire in elk van deze toekomstverkenningen het (dominante) 'werkrepertoire' zou zijn. 


\section{Functionele betekenissen}

In hoofdstuk 3 heb ik laten zien dat toekomstverkenners meerdere functionele betekenissen aan een veel gebruikte techniek, het zogenaamde assenstelsel, toekenden en dat die verschillende functionele betekenissen gedurende het hele proces van toekomstverkennen naast elkaar bestonden en met elkaar concurreerden.

Om deze verschillende functionele betekenissen te duiden gebruikte ik drie bouwmetaforen. In 'het assenstelsel als skelet' werd het assenstelsel opgevat als een "standaard" voor het maken van scenario's: zoals een skelet vorm geeft aan lichamen en gebouwen, zo zou het assenstelsel de verhalen bepalen die kunnen worden verteld over de toekomst. Toekomstverkenners die het assenstelsel gebruikten als fundering presenteerden het assenstelsel primair als een processtructuur. In de derde functionele betekenis, 'het assenstelsel als bouwstelling', werd het assenstelsel opgevat als een heuristiek en hulpmiddel om vier mogelijke toekomsten te doordenken. Het assenstelsel wordt in deze benadering gebruikt om de scenario's in de steigers te zetten, maar deze functie verdwijnt als dit eenmaal is gedaan.

Achter elke functionele betekenis schuilde een ander perspectief op de kenbaarheid van de toekomst en daarmee ook op het proces van toekomstverkenning.

Toekomstverkenners die het assenstelsel opvatten als een skelet gingen ervan uit dat de toekomst min of meer kenbaar is. De aanname was dat, door de twee meest onzekere ontwikkelingen met de grootste impact te identificeren, inzicht verkregen kan worden in hoe de drijvende krachten het systeem naar de toekomst voort kunnen stuwen en daarmee hoe de toekomst er uit zou kunnen zien. In 'het assenstelsel als fundering gingen toekomstverkenners er niet van uit dat de toekomst kan worden gekend door de twee belangrijkste drijvende krachten te 'ontdekken', maar ging het in toekomstverkenning vooral om het in kaart brengen van inschattingen en verwachtingen van experts en mensen in het veld. In deze benadering gebruikten toekomstverkenners naast impact en onzekerheid daarom ook 'draagvlak' als criterium voor het selecteren van twee drijvende krachten. In 'het assenstelsel als bouwstelling' gingen toekomstverkenners ervan uit dat de toekomst per definitie niet te kennen is en dat er niet twee drijvende krachten 'zijn' of moeten worden 'gekozen', maar dat er een groot aantal variabelen zijn die in de toekomstverkenning in onderlinge samenhang zouden moeten worden beschouwd. In de praktijk bleken vooral aanhangers van de fundering- en bouwstellingsbenadering met elkaar te concurreren: de twee benaderingen die het meest in lijn waren met de 'nieuwe' ambitie.

Het perspectief dat toekomstverkenners hadden op de kenbaarheid van de toekomst bepaalde de manier waarop toekomstverkenners over de toekomst communiceerden en hoe zij de toekomst visualiseerden. Toekomstverkenners die redeneerden vanuit de skeletbenadering verwezen naar de twee belangrijkste drijvende krachten en

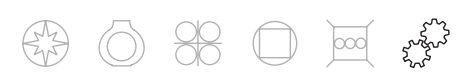


visualiseerden het assenstelsel als een 2x2-matrix met vier kwadranten en dus vier scenario's. Aan deze techniek kleefde een historisch-deterministische insteek, namelijk het idee dat er twee drijvende krachten kunnen worden onderscheiden die ook in de toekomst een bepalende rol zullen spelen. Het assenstelsel als fundering visualiseerden de toekomstverkenners als een tweedimensionale ruimte. De keuze van vier scenario's en de positionering deze scenario's in de kwadranten beschouwden zij als de uitkomst van een sociaal proces. Er zijn in deze benadering oneindig veel toekomstbeelden mogelijk, maar deze zijn wel begrensd door de vier hoekpunten. En welke vier toekomsten worden doordacht, wordt bepaald door de 'stem van de meerderheid'. Toekomstverkenners die het assenstelsel gebruiken als bouwstelling pleitten ervoor om, als de scenario's eenmaal in de steigers staan, het assenstelsel los en weg te laten. Deze toekomstverkenners wilden geen verwijzingen naar het assenstelsel in de uiteindelijke publicatie. Op deze manier wilden zij benadrukken dat de scenario's een integraal karakter hadden en niet slechts gebaseerd waren op twee veronderstelde drijvende krachten.

Hoewel de toekomstverkenners in SCENE uiteindelijk de skeletbenadering hadden laten vallen en de toekomst volgens de funderings- of bouwstellinglogica gingen verkennen, bleef het assenstelsel als skelet wel een rol spelen. Doordat de toekomstverkenners het skeletvocabulaire om strategische redenen bleven inzetten, bleven de drie verschillende repertoires door elkaar heen lopen. Door dit gebrek aan "repertoire-zuiverheid" (Mesman, 2002) en het in de praktijk niet (h)erkennen van het naast elkaar van fundamenteel verschillende perspectieven, ontstonden er allerlei spanningen. De toekomstverkenners dachten het eens te zijn en hadden het gevoel tot oplossingen en compromissen te komen, maar in de praktijk werden vermeende afspraken steeds weer ter discussie gesteld. Het gebruik van het assenstelsel als techniek om variatie te bewerkstelligen werd vanwege 'variatie over variatie' problematisch en waardoor ook het realiseren van de variatieambitie werd bemoeilijkt.

In de SCENE praktijk van toekomstverkennen herkenden de toekomstverkenners wel verschillende verwachtingen ten aanzien van het assenstelsel en verschillende omgangsvormen, maar bleven de onderliggende perspectieven op de kenbaarheid van de toekomst en daaraan gekoppeld de verschillende functionele betekenissen van het assenstelsel impliciet. En daarmee ook de spanningen tussen de skeletbenadering van het assenstelsel en de 'nieuwe' ambitie. Er bleken dus meer dimensies te zijn dan op het eerste oog zichtbaar waren. Oog voor deze multipliciteit en dus het naast elkaar bestaan, conflicteren en concurreren van verschillende functionele betekenissen is relevant om te kunnen begrijpen hoe toekomstverkenners kennis over de toekomst produceren, waarom spanningen optreden en hoe zij over het productieproces en het resultaat daarvan (namelijk 'toekomstkennis') communiceren. 


\section{Grensoverschrijdende objecten en transformatie van het grensgebied}

In hoofdstuk 4 analyseerde ik de samenwerking tussen twee verschillende culturen van toekomstverkenning, namelijk 'onderzoek' en 'ontwerp'. Ik liet zien dat, verwijzend naar verschillende wetenschapssociologische studies naar de collectieve constructie van kennis, grensoverschrijdende objecten nodig zijn om samenwerking tussen verschillende culturen van toekomstverkenning mogelijk te maken. In de WVR-praktijk van toekomstverkenning konden twee potentieel grensoverschrijdende objecten worden onderscheiden, die de toekomstverkenners hadden gepositioneerd op het "grensgebied" van de domeinen onderzoek en ontwerp. Dit waren de zogenaamde "potentiekaarten" en "signalen".

Ik heb beschreven hoe toekomstverkenners er niet in slagen om deze potentieel grensoverschrijdende objecten te laten werken als infrastructuur waarlangs communicatie tussen de twee culturen van toekomstverkenning kan plaatsvinden. Omdat die communicatie niet kon plaatsvinden werd de integratieambitie (onbedoeld) gedurende het proces ondermijnd. Dit ondermijnen van de integratieambitie verliep langs een aantal stappen. Allereerst ontstonden er grensconflicten tussen onderzoekers en ontwerpers, die tot uitdrukking kwamen in discussies over wie de verantwoordelijkheid hadden voor het tot stand komen van de potentiekaarten en signalen (onderzoekers of ontwerpers). Toekomstverkenners probeerden deze conflicten op te lossen door de potentieel grensoverschrijdende objecten uit het grensgebied te plaatsen en toe te bedelen of in de domeinen onderzoek of ontwerp. Hierdoor verdween de noodzakelijke infrastructuur waarlangs het grensverkeer tussen beide culturen van toekomstverkenning kon gaan plaatsvinden; en daarmee verdween ook de infrastructuur voor samenwerking.

In hoofdstuk 4 zagen we dat het integratiemodel dat de toekomstverkenners voor ogen hadden plaats maakte voor een 'vervreemdingsmodel'. Door het verplaatsen van de potentieel grensoverschrijdende objecten en het blokkeren van het grensverkeer tussen beide domeinen trad er een transformatie op van het grensgebied: het grensgebied ontvolkte en beide culturen versterkten hun domeingrenzen. Dit resulteerde uiteindelijk in het ontstaan van een niemandsland of 'no go-area' tussen beide culturen van toekomstverkenning, waardoor het voor de toekomstverkenners onmogelijk werd om een "common ground" te creëren. Onderzoekers en ontwerpers gingen steeds meer onafhankelijk van elkaar, dus binnen hun eigen domein, de toekomst verkennen.

In de loop van de toekomstverkenning werd er steeds duidelijker een hiërarchie gecreëerd tussen onderzoekers en ontwerpers, waarbij het ontwerp ondergeschikt gemaakt werd aan het onderzoek. Er is dan niet langer sprake van een vervreemdingsmodel, maar van een 'hiërarchisch model', waarin de onderzoekers gingen domineren. Uiteindelijk degradeerden de onderzoekers de door de ontwerpers gemaakte producten van toekomstverkennen tot "plaatjes". En tenslotte verdween het

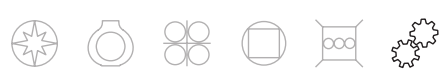


ontwerp als toekomstverkenningsactiviteit. Omdat er geen grensgebied meer was, en het vervreemdingsmodel was verschoven naar een hiërarchisch model, kwam het ontwerp als vorm van toekomstverkenning in het geding. En daarmee werd de integratieambitie (onbedoeld) ondermijnd.

Door de samenwerking tussen verschillende culturen van toekomstverkenning in VVR vanuit een 'tijdslens' te beschouwen kon ik beter duiden waarom deze spanningen optraden en waarom ontwerp als vorm van toekomstverkenning kon worden gemarginaliseerd.

Bij het falen van de integratieambitie speelden verschillende factoren een rol, zoals het niet op waarde schatten van de noodzakelijke grensoverschrijdende objecten. Dit leidde ertoe dat het grensgebied, waar de verschillende culturen elkaar hadden moeten ontmoeten, transformeerde in een 'no go-area'. En door het optreden van vervreemding en uiteindelijk ook hiërarchie tussen de beide culturen van toekomstverkenning werd het zo goed als onmogelijk om de integratieambitie te realiseren. Een tweede duiding kan worden gevonden in het niet erkennen van fundamenteel verschillende temporele perspectieven, waardoor het historisch-deterministische denken, dat vooral door de onderzoekers werd ingebracht, uiteindelijk kon gaan domineren. Door het dominant worden van het historisch-deterministische denken, dat op gespannen voet staat met de 'nieuwe' ambitie, werd het zo goed als onmogelijk om de integratieambitie te realiseren.

\section{Importantie van het historisch-deterministische repertoire en schakelen tussen ambities}

In de RPB-praktijk van toekomstverkennen bleken beide temporele repertoires steeds naast elkaar te bestaan en met elkaar te concurreren. Toekomstverkenners herkenden het fundamenteel verschillende karakter van verschillende perspectieven op 'tijd' en de manier waarop verleden, heden en de toekomst aan elkaar kunnen en zouden moeten worden verknoopt in toekomstverkenning niet. En hierdoor gaven zij tijdens het verkennen van de toekomst (onbedoeld) steeds meer ruimte aan historischdeterministische redeneerpatronen, die veel meer in lijn waren met de 'oude' traditie en op gespannen voet te stonden met de veronderstelde 'nieuwe' manier van toekomstverkennen. Uiteindelijk werd het historisch-deterministische repertoire in zowel WR als WLO zelfs dominant, waardoor het realiseren van de 'nieuwe' ambities niet alleen problematisch, maar zelfs onmogelijk werd.

Het realiseren van de variatie- en/of integratieambitie is dus allesbehalve onproblematisch. In SCENE en WLO veronderstelden de toekomstverkenners een consensus die er niet was. In SCENE was deze schijnconsensus impliciet. De toekomstverkenners constateerden wel dat er in de praktijk verschillende manieren waren 
waarop het assenstelsel werd gebruikt, maar waren zich niet bewust van de verschillende functionele betekenissen van het assenstelsel en de fundamenteel verschillende perspectieven op toekomstverkenning die daaraan ten grondslag lagen. In WLO was het veronderstellen van consensus meer expliciet, wat bijvoorbeeld tot uitdrukking kwam in de strategie verschillen en tegenstrijdigheden weg te poetsen. Anders was dit in WVR. Deze toekomstverkenners waren zich wel bewust van het bestaan van fundamenteel verschillende perspectieven op toekomstverkenning en ontwikkelden een manier om twee culturen van toekomstverkenning te laten integreren. De toekomstverkenners slaagden er uiteindelijk niet in de integratieambitie te realiseren, waarmee de productie van toekomstkennis in deze toekomstverkenning dreigde 'vast' te lopen.

De integratie- en variatieambities boden in de praktijk weinig structuur en richting aan het handelen. Het was wel een vertrekpunt, maar gedurende het proces traden verschillende spanningen en tegenstrijdigheden op en waardoor het vormgeven van de ambities zeer moeizaam of helemaal niet realiseerbaar was. De ambities waren, met andere woorden, niet meer maar ook niet minder dan een vertrekpunt voor het verkennen van de toekomst. De productiefase stond niet zozeer in het teken van het uitwerken van die ambities, maar vooral van het worstelen met het historisch-deterministische denken en met technieken als het assenstelsel waar een historisch-deterministische insteek aan kleeft. In de presentatiefase gingen de ambities echter wel een sturende rol spelen toen de toekomstverkenners weer gingen appelleren aan de 'nieuwe' toekomstoriëntatie.

Ik heb laten zien dat toekomstverkenners het in de praktijk vastlopen of niet kunnen realiseren van de 'nieuwe' ambities opvingen door te "schakelen" tussen de integratieen variatieambitie. In SCENE, het project dat was gestart vanuit de variatieambitie, mobiliseerden de toekomstverkenners de integratieambitie om uiteindelijk de keuze voor één van de drie functionele betekenissen te motiveren en te kunnen legitimeren. In WR schakelden de toekomstverkenners juist van de integratie- naar variatieambitie om het vastlopen van de integratieambitie op te vangen en daarbij te kunnen blijven appelleren aan de 'nieuwe' toekomstoriëntatie. De toekomstverkenners mobiliseerden dus in de presentatiefase een ambitie die wel appelleerde aan de 'nieuwe' manier van toekomstverkenning, maar die niet de oorspronkelijke ambitie was en die ook niet centrale activiteit was in de productiefase.

\section{Het paradoxspel van toekomstverkenners}

Ik heb laten zien dat door het schakelen tussen de twee toekomstverkenningsambities (en daarbij blijven appelleren aan de 'nieuwe' toekomstoriëntatie) in toekomstverkenningen een paradox ontstaat. Zowel in WV als in WLO trad er tijdens het productieproces een verschuiving op, waarbij toekomstverkenners - bewust of onbewust - de onzekerheden van de toekomst (die het startpunt waren van de

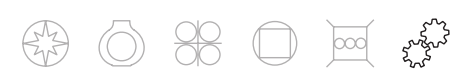


toekomstverkenning) steeds meer gingen mijden. De zekerheden van het heden en verleden werden steeds meer richtinggevend in het doen van uitspraken over de toekomst en het creëren van waarschijnlijkheid werd belangrijker dan het verkennen van mogelijke en nieuwe toekomsten. Hierdoor werden de 'nieuwe' ambities beetje bij beetje ondermijnd. Hoewel de toekomstverkenners zichzelf expliciet tot doel hadden gesteld trendbreuken, verrassingen, radicale omwentelingen en systeemveranderingen te bestuderen, domineerde in deze toekomstverkenningen uiteindelijk het historischdeterminisme denken en verdween het denken in discontinuïteiten steeds verder naar de achtergrond. Toekomstverkenners gingen in de praktijk vaak datgene doen wat juist niet hun oorspronkelijke ambitie was, namelijk het verkennen vanuit zekerheden.

Een manier waarop toekomstverkenners omgingen met het niet aansluiten van de toekomstverkenning bij de nieuwe toekomstoriëntatie, was het anders presenteren van de praktijk "frontstage" dan de "backstage" gang van zaken. Door te schakelen tussen ambities konden de toekomstverkenners, hoewel het productieproces op gespannen voet stond met de 'nieuwe' toekomstoriëntatie, de toekomstverkenning wel als onderdeel van de 'nieuwe' toekomstoriëntatie presenteren. In dit paradoxspel probeerden toekomstverkenners "frontstage" historisch-deterministisch getinte verwijzingen zo goed mogelijk weg te poetsen en hun publiek ervan te overtuigen dat de toekomstverkenning wel degelijk behoorde tot een 'nieuwe' generatie toekomstverkenningen en waarin het omgaan met onzekerheid en complexiteit centraal stond.

In de door mij geobserveerde praktijk van toekomstverkennen speelden toekomstverkenners een ander paradoxspel dan het spel dat bijvoorbeeld werd beschreven door Bal, Bijker, \& Hendriks (2002) en Hilgartner (2000). Volgens deze auteurs is het paradoxspel noodzakelijk voor kennisproducenten om autoriteit te kunnen verwerven. In de praktijk van toekomstverkenning beantwoordt, in tegenstelling tot bijvoorbeeld de praktijk van de Gezondheidsraad, het proces "backstage" veel meer aan een positivistisch wereldbeeld, waarin "het weten" en het baseren van uitspraken in waarnemingsfeiten centraal staan. Terwijl toekomstverkenners frontstage hun toekomstverkenning en de door hun geproduceerde toekomstkennis presenteren in 'constructivistische' termen. In de definitie- en presentatiefase benadrukken toekomstverkenners veel meer het "niet weten", de onzekerheid en complexiteit waarmee het verkennen van de toekomst is omgeven en daarmee het constructivistische karakter van kennis over de toekomst. Toekomstverkenners lijken, met andere woorden, een omgekeerd paradoxspel te spelen. 


\subsection{Suggesties voor toekomstverkenners}

In hoofdstuk 1 beloofde ik verschillende patronen en mechanismen te beschrijven die ten grondslag liggen aan toekomstverkenning. Ik wilde niet pretenderen dat de drie toekomstverkenningen waarop ik mijn onderzoek vooral baseerde representatief waren voor de manieren waarop de toekomst bij andere instituten en door andere toekomstverkenners wordt verkend. Wel denk ik dat de door mij beschreven patronen en mechanismen, al dan niet in andere gedaanten, in een andere volgorde, of met een andere uitwerking, ook terug te vinden zijn in andere praktijken van toekomstverkenning en dat mijn onderzoek, met andere woorden, generaliseerbare inzichten biedt over de productie van toekomstkennis.

Het produceren van kennis over de toekomst bleek niet hetzelfde te zijn als het realiseren van gestelde ambities, maar bleek vooral te kunnen worden gekarakteriseerd als het worstelen met het historisch-deterministische denken. De grootste uitdaging in toekomstverkenning lijkt te zijn manieren te vinden om kennis over heden en verleden te gebruiken om iets te zeggen over de toekomst zonder dat er allerlei moeizame spanningen en problematische tegenstrijdigheden optreden. Daarbij lijkt het cruciaal te zijn dat toekomstverkenners zich tijdens het productieproces bewust zijn van het naast elkaar bestaan, conflicteren en al dan niet concurreren van verschillende temporele perspectieven, functionele betekenissen en culturen van toekomstverkennen.

De vraag in hoeverre de 'nieuwe' ambities 'nieuw' zijn, kan ik op basis van dit onderzoek niet beantwoorden, want de 'oude' ambities en de 'oude' praktijken heb ik niet onderzocht. Wel lijkt het, gezien de manier waarop toekomstverkenners toekomstkennis produceren, de vraag of het maken van een onderscheid tussen 'oud' en 'nieuw' productief is, omdat toekomstverkenners hierdoor in een spagaat terecht lijken te komen.

Toekomstverkenners lijken twee wegen in te kunnen slaan: indien zij geen afstand kunnen of willen nemen van een historisch-deterministisch perspectief op toekomstverkenning, dan kunnen zij de tegenstelling tussen 'oud' en 'nieuw' beter loslaten en erkennen dat er meer continuïteit is met de 'oude' voorspellende traditie dan zij nu vaak veronderstellen. Toekomstverkenners zouden zich dan niet langer moeten afzetten tegen de oude generatie, maar bescheidener zijn en de ambities laten vallen die bij de 'nieuwe' toekomstoriëntatie horen. Een andere richting zou zijn dat zij radicaal voor de nieuwe ambitie(s) kiezen en dan ook daadwerkelijk (blijven) redeneren vanuit de onzekerheden van de toekomst. Toekomstverkenners moeten dan voorkomen dat zij in de loop van de verkenning onzekerheden wegredeneren door expliciet ruimte te blijven geven aan het "nieuwe" en het "andere". Zeker in tijden van onzekerheid en complexiteit lijkt deze weg te verkiezen boven de meer traditionele manier van toekomstverkenning. 
Dit is een fundamenteel andere weg die ook fundamenteel andere eisen stelt aan toekomstverkenners en de productie van toekomstkennis. Toekomstverkenners die voor deze tweede optie kiezen, zouden zekerheden los moeten laten en daadwerkelijk het onzekere voor het zekere durven te nemen. En dit betekent dat het verleden en heden dienen te worden gebruikt als 'springplank' en niet als 'hangmat'.

Om deze sprong naar de toekomst te maken zou het helpen als toekomstverkenners bekende, traditionele gebruik van instrumenten, methoden en technieken durven Ioslaten: Denken vanuit onzekerheid vereist dat de beschikbare methoden, technieken en aanpakken niet langer in de klassieke zin gebruikt worden (dat wil zeggen als recept of oplossing), maar hooguit als middel om reflectie en kritische wetenschap te stimuleren en te faciliteren (vergl. van Asselt \& Petersen, 2003). Als deze keuze niet expliciet wordt gemaakt, dan is de kans groot dat er moeizame spanningen en problematische tegenstrijdigheden blijven optreden in de productie van toekomstkennis. 
3

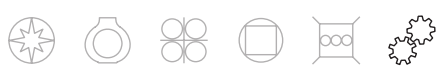




\section{Referenties}

Adam, B. (1994). Time and social theory. Cambridge: Policy Press.

Agar, M. (1980). The professional stranger. New York: Academic Press.

Armstrong, J. S. (2001). Principles of Forecasting: A Handbook for Researchers and

Practitioners. Boston, Dordrecht, London: Kluwer Academic Publishers.

Ashmore, M., Myers, G., \& Potter, J. (1995). Discourse, Rhetoric, Reflexivity: Seven days in the library. In S. Jasanoff, G. E. Markle, J. C. Petersen \& T. Pinch (Eds.), Handbook of Science and Technology Studies (321-342). Thousand Oaks, London, New Delhi: Sage Publications

van Asselt, M. B. A. (2000). Perspectives on Uncertainty and Risk: The PRIMA approach to decision support. Dordrecht, The Netherlands: Kluwer Academic Publishers.

van Asselt, M. B. A. (2003). Discussienotitie Vernieuwingsimpulsproject Methodologie voor toekomstverkenning. Maastricht: Universiteit Maastricht, Faculteit der Cultuurwetenschappen.

van Asselt, M. B. A., de Wilde, R., van der Pas, J. W., Wolthuis, J. A., \& (en anderen). (2005). Houdbaarheid verstreken: Toekomstverkenning en beleid. Den Haag: Ministerie van Binnenlandse Zaken en Koninkrijksrelaties.

van Asselt, M. B. A., \& Petersen, A. C. (Eds.). (2003). Niet bang voor onzekerheid. Den Haag: Lemma / RMNO.

van Asselt, M. B. A., Rotmans, J., \& Greeuw, S. C. H. (2001). Puzzle-solving for policy : A provisional handbook for Integrated Assessment. Maastricht, The Netherlands: ICIS \& EFIEA.

van Asselt, M. B. A., Rotmans, J., \& Rothman, D. S. (2005). Scenario innovation: Experiences from a European experimental garden: Taylor \& Francis.

van Asselt, M. B. A., \& van 't Klooster, S. A. (in preparation). Future Telling Practice: Multiplicity of functional meanings and challenges on stage. Science, Technology \& Human Values.

van Asselt, M. B. A., van ,t Klooster, S. A., \& van Notten, Ph. W. F. (2003). Verkennen in onzekerheid. Beleid en Maatschappij, 30(4), 230-241.

Bakker, W. (2003). Scenario's tussen rationaliteit, systeemdwang en politieke rede. Beleid en Maatschappij, 30(4), 219-229.

Bal, R., Bijker, W. E., \& Hendriks, R. (2002). Paradox van wetenschappelijk gezag: Over de maatschappelijke invloed van adviezen van de Gezondheidsraad. Den Haag: Gezondheidsraad.

Barbieri Masini, E. (1988). Future technology and its social implications. World Futures Studies Federation Newletter, 14(1), 17.

Barker, J. (1996). Paradigms. The business discovering the future. Harper Business.

Beers, P. J. (2005). Negotiating Common Ground. Tools for multidisciplinary teams. Open Universiteit Nederland, Heerlen.

Bell, W. (2000). Foundations of Futures Studies: Human science for a new era (Vol. 1). New Brunswick: Transaction Publishers.

van den Berg, E., \& van Houtum, H. J. (2003). Routing Borders between territories, discourses and practices. Ashgate: Aldershot. 


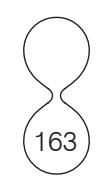

Berkhout, F., \& Hertin, J. (2002). Foresight futures scenarios: Developing and applying a participative strategic planning tool. Futures, 37(Spring), 37-52.

Bijker, W. E., Hughes, T., \& Pinch, T. (1987). The Social Construction of Technological Systems: New directions in the sociology and history of technology. Cambridge, USA: MIT Press.

Bijker, W. E. (1995). Of Bicycles, Bakelites, and Bulbs: Toward a theory of sociotechnical change. Cambridge, USA: MIT Press.

Bovens, M., \& 't Hart, P. (1996). Understanding policy fiascoes. New Brunswick, USA: Transaction Publishers.

Bowker, G. C. (forthcoming). Memory Practices in the Sciences.

Bradfield, R., Wright, G., Burt, G., Cairns, G., \& van der Heijden, K. (2005). The origins and evolution of scenario techniques in long range business planning. Futures, 37(8), 795-812.

Brier, D. J. (2005). Marking the future: a review of time horizons. Futures, 37, 833-848.

Brooks, L. J. (2004). Working in the future tense: Materializing stories of emerging technologies and cyberculture at the Institute of the Future University of California, San Diego.

Brosveet, J. (2004). Translation terrain and pied piper detour: How experts eliminated a Norwegian digital city project. Science, Technology \& Human Values, 29(2), 213-241.

Brown, N., Rappert, B., \& Webster, A. (2000). Contested futures: A sociology of prospective techno-science. Aldershot, UK: Ashgate.

BZK. (2003). Scenario's en zo: een handreiking voor scenarioplanning. Den Haag: Ministerie van Binnenlandse Zaken en Koninkrijksrelaties.

BZK. (2005). Toekomstverkennen. De radar op scherp. Den Haag: Ministerie van Binnenlandse Zaken en Koninkrijksrelaties, SKO.

Cairncross, A. (1969). Economic Forecasting. Economic Journal, 79, 797-812.

Calder, N. (1969). Technopolis: Social control of the uses of science. London.

Callon, M. (1986). Some Elements of a Sociology of Translation: Domestication of the Scallops and the Fishermen of St. Brieuc Bay. In J. Law (Ed.), Power, Action, and Belief. Boston: Routledge and Kegan Paul.

Cammen, H. v. d., \& de Klerk, L. (2003). Ruimtelijke ordening: Van grachtengordel tot Vinex-wijk. Utrecht: Uitgeverij Het Spectrum bv.

Carton, L., \& Karstens, S. (2002). The W4S Game: Exploring the Future Consequences of Water Management. In I. Mayer \& W. Veeneman (Eds.), Games in a World of Infrastructure: Simulation-games for Research, Learning and Intervention (pp. 85-105). Delft: Eburon.

CBS/RIVM. (2004). Lange-termijn bevolkingsscenario's voor Nederland. Bilthoven: Rijksinstituut voor Volksgezondheid en Milieu.

Clark, W. C. (1986). Sustainable development of the biosphere: themes for a research program. In W. C. Clark \& R. E. Munn (Eds.), Sustainable Development of the Biosphere. Cambridge, UK: Cambridge University Press. 
Clark, W. C. (1988). Visions of the 21st century: Conventional wisdom and other surprises in the global interactions of population, technology and environment. In $\mathrm{K}$. Newton, T. Schweiter \& J. P. Voyer (Eds.), Perspective 2000: Economic Council of Canada.

Clarke, A. E., \& Fujimura, J. H. (1992). The right tools for the job: At Work in TwentiethCentury Life Science. Princeton, New Jersey: Princeton University Press,.

Collins, H. M. (1981). Stages is the Empirical Programme of Relativism. Social Studies of Science, 11(1), 3-10.

Collins, H. M. (1984). Researching spoonbending: Concepts and practice of participatory fieldwork. In C. Bell \& H. Roberts (Eds.), Social researching: Politics, Problems, Practice: Routledge \& Kegan Paul.

Collins, H. M. (1985). Changing Order: Replication and induction in scientific practise. London, UK: Sage.

CPB. (1985). De Nederlandse economie op langere termijn; drie scenario's voor de periode 1985-2010. Den Haag: SDU uitgevers.

CPB. (1992). Scanning the Future: A long term scenario study of the world economy 1990-2015. The Hague, The Netherlands: Sdu Uitgevers.

CPB. (1997). Economie en fysieke omgeving: Beleidsopgaven en oplossingsrichtingen 1995-2020. Den Haag: SDU uitgevers.

CPB. (2003). Four Futures of Europe. Den Haag: CPB.

Czarniawska, B. (1997). Narrating the Organization: Dramas of Institutional Identity. Chicago: The University of Chicago Press.

Dammers, E. (2000). Leren van de toekomst. Over de rol van scenario's bij strategische beleidsvorming. Delft: Eburon.

de Jouvenel, B. (1963). Introduction. In B. de Jouvenel (Ed.), Futuribles. Geneva: Droz.

de Jouvenel, B. (1967). The Art of Conjecture. New York: Basic Books.

Derksen, W. (2002). Planbureau voor schaarse ruimte Het financiële dagblad.

van Dijck, J. (1997). Het verbeeldingstekort. Kennis en Methode, 21, 83-96.

Dobbinga, E. (2001). Weerbarstigheid van organisatiecultuur: een organisatieantropologische studie naar betekenisgeving aan moderne managementinstrumenten. Delft: Eburon.

Don, H. (2003). De rol van het CPB. Economische Statistische Berichten, 20.

Dresen, L. (2003). Deskundigheid en onzekerheid in de geschiedenis van het beleidsadvies. In M. B. A. van Asselt \& A. Petersen (Eds.), Niet bang voor onzekerheid (Vol. RMNO-reeks, voorstudie nr. V.01, pp. 7-24). Den Haag: Lemma bv.

van der Duin, P. A., Hazeu, C. A., Rademaker, P., \& Schooneboom, I. J. (2006). The future revisited: Looking back at The next 25 years by the Netherlands Scientific Council for Government Policy (WRR). Futures, 38, 235-246.

van der Duin, P. A., Hazeu, C. A., Rademaker, P., \& Schooneboom, I. J. (Eds.). (2004). Vijfentwintig jaar later: De toekomstverkenning van de WRR uit 1977 als leerproces. Amsterdam: Amsterdam University Press. 
van der Duin, P. A. \& Stavleu, H. (2006). De toekomst in een notendop. Amsterdam: Uitgeverij Bert Bakker.

ECN. (1987). Nationale Energieverkenningen 1987 (No. ESC-42). Petten: ESC.

ECN. (1998). Nationale Energie Verkenningen 1995 - 2020: Trends en thema's. Petten: Energieonderzoek Centrum Nederland (ECN) - Beleidsstudies.

ECN. (2005). Referentieramingen energie en emissies 2005-2020. Petter: ECN Beleidsstudies.

EEA. (1995). Environment in the European Union: Report for the review of the fifth environmental action programme. Copenhagen, Denmark: European Environment Agency.

van Eeten, M. (1999). Dialogues of the Deaf. Defining New Agendas for Environmental Deadlocks. Delft: Eburon Publishers.

van Egmond, K. (1999, 3 februari 1999). Modellen geven meetresultaten betekenis. Trouw.

Eisenhardt, K. M. (1989). Building Theories from Case Study Research. Academy of Management Review, 532-550.

Essent N.V. (2003). Beleef 2030: 4 toekomstscenario's voor de energiewereld: Essent N.V.

Essent N.V. (2004). Beproef 2003: 4 toekomstscenario's in perspectief: Essent N.V.

Ester, P., Geurts, J., \& Vermeulen, M. (Eds.). (1997). De makers van de toekomst: Over nut en noodzaak van toekomstverkenningen voor beleidsonderzoek. Tilburg: Tilburg University Press.

Fine, G. A. (forthcoming). Through a glass, darkly: Meteorological forecasts and the promise of futurework.

Fowles, J. (1978). Handbook of Futures Research. Westport, CT: Greenwood.

Freilich, M. (1970). Marginal natives. New York: Wiley.

Fujimura, J. H. (1992). Crafting Science: Standardized Packages, Boundary Objects, and "Translation". In A. Pickering (Ed.), Science as Practice and Culture (pp. 168215). Chicago/London: The University of Chicago Press.

Gabor, D. (1964). Inventing the future. New York: Alfred A. Knopf.

Galison, P. (1999). Trading Zone: Coordinating Action and Belief. In M. Biagioli (Ed.), The Science Studies Reader. New York en Londen: Routledge.

Galtung, J. (2003). What did people predict for the year 2000 and what happened. Futures, 35(2), 107-121.

Gasser, L., \& Huhns, M. (1989). Distributed Artificial Intelligence (Vol. II). San Mateo (CA): Morgan Kaufmann Publishers, Inc.

Gell, A. (1992). The anthropology of time. Cultural constructions of temporal maps and images. Oxford/Providence: Berg.

Gieryn, T. F. (1995). Boundaries of science. In S. Jasanoff, G. E. Markle, R. E. Petersen \& T. Pinch (Eds.), Handbook of Science and Technology Studies. London, UK: SAGE.

Gilbert, G. N., \& Mulkay, M. (1984). Opening Pandora's Box: A sociological analysis of 
scientists' discourse. Cambridge: Cambridge University Press.

Glaser, B. G., \& Strauss, A. L. (1967). The discovery of grounded theory: Strategies for qualitative research. Chicago, USA: Aldine.

Goffman, E. (1959). The presentation of self in everyday life. New York, USA: Doubleday Anchor Books.

Gurevich, A. J. (1976). Time as a problem of cultural history. Paris: The Unesco Press.

Hagendijk, R. (1996). Wetenschap, Constructivisme en Cultuur. Universiteit van Amsterdam, Amsterdam.

Halffman, W. (2003). Boundaries of regulatory science: Eco/toxicology and aquatic hazards of chemicals in the US, England, and the Netherlands, 1970-1995. Universiteit van Amsterdam (UvA), Amsterdam, the Netherlands.

Halffman, W., \& Hoppe, R. (forthcoming). Science/policy boundaries: a changing division of labour in Dutch expert policy advice. In S. Maasse \& P. Weingart (Eds.), Scientific Expertise and Political Decision Making. Dordrecht, the Netherlands: Kluwer.

Hammersley, M., \& Atkinson, P. (1995). Ethnography: Principles in Practice (second edition). London and New York: Routledge.

van der Heijden, K. (1996). Scenarios: the Art of Strategic Conversation. England: Wiley.

Helmer, O. (1983). Looking Forward: A Guide to Futures Research. Beverly Hills, CA: Sage.

Hess, D. (2001). Ethnography and the development of science and technology studies. In P. Atkinson, A. Coffey, S. Delamont, J. Lofland \& L. Lofland (Eds.), Handbook of ethnography: London: SAGE.

Hess, D. J. (1995). Science and Technology in a Multicultural World: The cultural politics of facts and artifacts. New York, USA: Columbia University Press.

Hilgartner, S. (2000). Science on stage: Expert advice as public drama. Stanford, USA: Stanford University Press.

Hill, K. Q., \& Fowles, J. (1975). The methodological worth of the Delphi forecasting technique. Technological Forecasting and Social Change, 7, 179-192.

Hoppe, R. (2005). Rethinking the science-policy nexus: from knowledge utilization and science technology studies to types of boundary arrangements. Poièsis and Praxis: International Journal of Technology Assessment and Ethics in Science, 3(3), 199-215.

IPCC. (1990). Climate Change: The IPCC Scientific Assessment. Cambridge, UK:

Cambridge University Press.

IPCC. (1996). Climate Change 1995: Impacts, Adaptations and Mitigation of Climate

Change: Scientific - Technical Analyses. Cambridge: Press Syndicate.

IPCC. (2000). Third Assessment Report (TAR) of Working Group 1. Cambridge: Cambridge University Press.

Jantsch, E. (1967). Technological forecasting in perspective: A framework for technological forecasting, its techniques and organisation. Paris, France: OECD. 
Jasanoff, S., Markle, G. E., Petersen, J. C., \& Pinch, T. (Eds.). (1995). Handbook of Science and Technology Studies. Thousands Oaks, USA: SAGE Publications. Jasanoff, S., \& Wynne, B. (1998). Science and Decision-making. In S. Rayner \& E. L. Malone (Eds.), Human Choice and Climate Change (Vol. 1 - The societal framework). Washington D.C., USA: Battelle Press.

de Jong, W. (1997). Scenario's 2030 zijn geen wishful thinking. NRC 14 juli 1997. Jordan, K., \& Lynch, M. (1992). The sociology of a genetic engineering technique: ritual and rationality in the performance of the "Plasmid Prep". In A. E. Clarke \& J. H. Fujimura (Eds.), The right tools for the job: At work in twentieth-century life science. New Jersey: Princeton University Press.

Kahn, H., \& Wiener, A. (1967). The Year 2000. New York: MacMillan.

Klein, J. T. (1996). Crossing boundaries: Knowledge, disciplinarities, and interdisciplinarities. Charlottesville: University Press of Virginia.

van 't Klooster, S. A., \& van Asselt, M. B. A. (2006). Practising the scenario-axes technique. Futures, 38(1), 15-30.

Knorr-Cetina, K. (1981). The manufacture of knowledge: An essay on the constructivist and contextual nature of science. Oxford: Pergamon.

Knorr-Cetina, K. (1995). Laboratory studies: The cultural approach to the study of science. In S. Jasanoff, G. E. Markle, J. C. Petersen \& T. Pinch (Eds.), Handbook of science and technology studies: SAGE.

Koselleck, R. (1985). Futures past: On the semantics of historical time. Cambridge, USA: MIT Press.

Kuhn, T. S. (1970). The Structure of Scientific Revolutions. Chicago, USA: University of Chicago Press.

de Laat, B. (2000). Scripts for the future: Using innovation studies to design foresight tools. In N. Brown, B. Rappert \& A. Webster (Eds.), Contested futures: A sociology of prospective techno-science. Aldershot, UK: Ashgate.

Latour, B. (1987). Science in Action: How to Follow Scientists and Engineers through Society. Cambridge, USA: Harvard University Press.

Latour, B. (1988). Wetenschap in actie: Wetenschappers en technici in de maatschappij. Amsterdam: Bert Bakker.

Latour, B. (1999). Pandora's Hope: Essays on the Reality of Science Studies. Cambridge: Harvard University Press.

Latour, B., \& Woolgar, S. (1979). Laboratory Life: The social construction of scientific facts. Beverly Hills, USA: Sage.

Latour, B., \& Woolgar, S. (1986). Laboratory Life: The construction of scientific facts (2nd edition with new postscript by the authors ed.). Oxford, UK: Princeton University Press.

Lattuca, L. R., Voight, L. J., \& Fath, K. Q. (2004). Does interdisciplinarity promote learning? Theoretical support and researchable questions. The Review of Higher Education, 28(1), 23-48.

Lave, J., \& Wenger, E. (1991). Situated learning: Legitmate peripheral participation. New 
York, USA: Cambridge University Press.

Lempert, R. J., Popper, S. W., \& Bankes, S. C. (2003). Shaping the Next One Hundred Years: New methods for quantitative long-term policy analysis. Santa Monica, USA: RAND.

van Lente, H. (1993). Promising technology: The dynamics of expectations in technological developments. Twente University, Enschede, the Netherlands. van Lente, H. (2000). Forceful futures: From promise to requirement. In N. Brown, B. Rappert \& A. Webster (Eds.), Contested futures: A sociology of prespective techno-science. Aldershot, UK: Ashgate.

Linstone, H. A., \& Turoff, M. (1975). The Delphi Method: Techniques and Applications. London: Addision-Wesley.

van Lohuizen, T. K. (1940). Het wetenschappelijk onderzoek in den stedebouw. Amsterdam.

van Lohuizen, T. K. (1948). De eenheid van het stedebouwkundig werk. Delft.

Lynch, M. (1985). Art and artifact in laboratory science: A study of shop work and shop talk in a research laboratory. London: Routledge \& Kegan Paul.

van Maanen, J. (1988). Tales of the Field: on Writing Ethnography Chicago: The University of Chicago Press.

Maasen, S. (2000). Inducing Interdisciplinarity: Irresistible Infliction? The example of a Research Group at het Center for Interdisciplinary Research (ZiF), Bielefeld, Germany. In P. Weingart \& N. Stehr (Eds.), Practicing Interdisciplinarity (pp. 173193). Toronto: University of Toronto Press.

de Man, R. (1987). Energy forecasting and the organization of the policy process. Delft, the Netherlands: Eburon.

Martinez, O. J. (1994). Border People. Life and Society in the US-Mexico Borderlands Tucson: University of Arizona Press.

McGee, M. C. (1980). The Ideograph. A Link Between Rhetoric and Ideology. The Quarterly Journal of Speech, 66, 1-16.

Meadows, D. H., Meadows, D. L., Randers, J., \& Behrens, W. W. (1972). The Limits to Growth. New York, USA: Universe Books.

Mesman, J. (2002). Ervaren pioniers: Omgaan met twijfel in de intensive care voor pasgeborenen: Aksant.

Michael, M. (2000). Futures of the Present: From Performativity to Prehension

In N. Brown, B. Rappert \& A. Webster (Eds.), Contested Futures. A sociology of prospective techno-science. Alershot, Burlington, Singapore, Sydney: Ashgate.

Middelkoop, H., van Asselt, M. B. A., van 't Klooster, S. A., van Deursen, W. P. A., Kwadijk, J. C. J., \& Buiteveld, H. (2004). Perspectives on flood management in the Rhine and Meuse rivers. River research and applications, 20, 327-342.

Nardi, B., \& Redmiles. (2002). Activity Theory and Design. Journal of ComputerSupported Cooperative Work, 11(1-2).

Neisser, U. (1976). Cognition and Reality. San Francisco (CA): W.H. Freeman.

Nio, I. (2003). Onderzoek en ontwerp in de verstrooide stad. S\&RO, 5, 6-9. 
van Notten, Ph. W. F., Rotmans, J., van Asselt, M. B. A., \& Rothman, D. S. (2003). An updated scenario typology. Futures, 35, 423-443.

van Notten, Ph. W. F. (2005). Writing on the Wall: Scenario development in times of discontinuity. Amsterdam, the Netherlands: Thela Thesis \& Dissertation.com.

van Notten, Ph. W. F., Sleegers, A. M., \& van Asselt, M. B. A. (2005). The future shocks:

On the role of discontinuity in scenario development. Technological forecasting and social change, 72, 175-194.

Nowotny, H. (1994). Time. The Modern and Postmodern Experience. Cambridge: Polity Press.

Nowotny, H., Scott, P., \& Gibbons, M. (2001). Re-Thinking Science: Knowledge and the public in an age of uncertainty. Cambridge, UK: Polity Press in association with Blackwell Publishers.

Parsons, T. (1970). Social Systems and the Evolution of Action Theory. New York: Free Press.

Pearsall, M. (1965). Participant observation as role and method in behavioural research. Nursing Research, 13, 37-42.

Rademaker, P. (1994). De rede(n) der toekomst (inaugurele rede). Enschede: Universiteit Twente.

Reichenbach, H. (1951). The Rise of Scientific Philosophy. Berkeley en Los Angeles: University of California Press.

Ringland, G. (Ed.). (2002). Scenarios in public policy: John Wiley and Sons Ltd., USA. RIVM. (1988). Zorgen voor Morgen. Alphen aan de Rijn: Samson H.D. Tjeenk Willink.

RIVM. (1993). Nationale Milieuverkenning 3: 1993-2015. Alphen aan den Rijn, the Netherlands: Samsom H.D. Tjeenk Willink.

RIVM. (1997). Nationale Milieuverkenning 4: 1997 - 2020. Alphen aan den Rijn: Samsom

H.D. Tjeenk Willink.

RIVM. (2000). Nationale Milieuverkenning 5: 2000 - 2030. Alphen aan den Rijn: Samson.

RIVM. (2004). Kwaliteit en toekomst: Verkenning van duurzaamheid. Den Haag: SDU uitgevers.

Rotmans, J. (1998a). Geïntegreerd denken en handelen: een noodzakelijk goed (inaugurele rede). Maastricht: Universiteit Maastricht.

Rotmans, J. (1998b). Methods for IA : The challenges and opportunities ahead. Environmental Modelling and Assessment, 3(3), 155-179.

Rowe, G., \& Wright, G. (1999). The Dephi technique as a forecasting tool: Issues and analysis. International Journal of Forecasting, 15, 353-375.

Rowe, G., \& Wright, G. (2001). Expert Opinion in Forecasting: The Role of the Delphi Technique. In J. Scott Armstrong (Ed.), Principles of Forecasting: A Handbook for Researchers and Practitioners (pp. 125-144). Boston/Dordrecht/London: Kluwer Academic Publishers.

RPB. (2001). Kennis van ruimte. Den Haag: Ministerie van Volkshuisvesting, Ruimtelijke Ordening en Milieu.

RPB. (2002a). Nederland in Europese Context. Toekomstscenario's tot 2030 (SCENE op 
internationaal niveau). Den Haag: RPB.

RPB. (2002b). Werkprogramma 2002-2003. Den Haag: Ruimtelijk Planbureau.

RPB. (2003a). De ongekende ruimte verkend. Rotterdam: NAi Uitgevers.

RPB. (2003b). SCENE: een kwartet ruimtelijke scenario's voor Nederland. Rotterdam: NAi Uitgevers.

RPB. (2004). RPB Werkprogramma 2004-2005 (versie 3 mei 2004. Retrieved 12 juni 2004, www.rpb.nl.

RPB. (2006). RPB Werkprogramma 2006-2007. Retrieved 3 juni 2006, www.rpb.nl

RPD. (1975). Scenario's ten behoeve van de Verstedelijkingsnota. Den Haag: RPD/VROM.

RPD. (1997). Nederland 2030. Discussienota. Verkenning Ruimtelijk Perspectieven. Den

Haag: Ministerie van Volkshuisvesting, Ruimtelijke Ordening en Milieu (VROM).

de Ruijter, P. (1975). De Rijksplanologische Dienst. Instelling en ontwikkeling: Technische Hogeschool Delft, Afdeling der Bouwkunde.

Schooneboom, I. J., \& van Latesteijn, H. C. (1997). Toekomstonderzoek en beleid. In .

NRLO \& Netwerk RO (Ed.), Toekomstonderzoek en strategische beleidsvorming (Vol. NRLO-rapport 93/3). Den Haag: NRLO.

Schooneboom, I. J. (2003). Toekomstscenario's en beleid. Beleid en Maatschappij, 30(4), 212-218.

Schwartz, M. S., \& Schwartz, C. G. (1955). Problems in Participant Observation. American Journal of Sociology, 60(4), 343-353.

Schwartz, P. (1991). The Art of the Long View: Planning for the Future in an Uncertain World. New York: Currency Doubleday.

Schwartz, P. (1995). Using scenarios to navigate the future (the internet).

Schwartz, P., \& Ogilvy, J. (1998). Plotting your scenarios. In L. Fahey \& M. Randall (Eds.), Learning from the future (pp. 57-80). USA: Wiley.

SCP. (2004). In het zicht van de toekomst: Sociaal en Cultureel Rapport 2004. Den Haag: SCP.

Smith, R. A., Vesga, D. R. A., Cadena, A. I., Boman, U., Larsen, E., \& Dyner, I. (2005). Energy scenarios for Colombia: Process and content. Futures, 37(1), 1-17.

Snellen, I. T. M. (2004). Vooronderstellingen voor een verrassingsvrije toekomstverkenning. In P. A. van der Duin, C. A. Hazeu, P. Rademaker \& I. J. Schooneboom (Eds.), Vijfentwintig Jaar Later: de Toekomstverkenning van de WRR uit 1977 als Leerproces (pp. 15-24). Amsterdam: Amsterdam University Press.

Spradley, P. D. (1980). Participant Observation. United States: Wadsworth - Thomson Learning.

van der Staal, P. M., \& van Vught, F. A. (1987). Vijftien jaar toekomstonderzoek door de WRR: de uitgestelde methodologische reflectie Deel 1. Beleidsanalyse, 87(4), 16-25.

van der Staal, P. M., \& van Vught, F. A. (1988). Vijftien jaar toekomstonderzoek door de WRR: de uitgestelde methodologische reflectie deel 2. Beleidsanalyse, 88(1), 5-17.

Star, S. L. (1989). The Structure of III-Structured Solutions: Boundary Objects and 
Heterogeneous Distributed Problem Solving. In M. Huhns \& L. Gasser (Eds.), Distributed Artificial Intelligence (Vol. II, pp. 37-53). San Mateo (CA): Morgan Kaufmann Publishers, Inc.

Star, S. L. (2002). Infrastructure and ethnographic practice. Scandinavian Journal of Information Systems, 14(2), 107-122.

Star, S. L., \& Griesemer, J. R. (1989). Institutional ecology, 'translation', and boundary objects: Amateurs and professionals in Berkeley's museum of vertebrate zoology, 1907-1939. Social studies of science, 19, 387-420.

van Steenbergen, B. (1990). Potential influence of the holistic paradigm on the social sciences. Futures, 1071-1083.

Swanborn, P. G. (1981/1994). Methoden van sociaal-wetenschappelijk onderzoek (1994 ed.). Meppel: Boom.

Thompson, M., Ellis, R., \& Wildavsky, A. (1990). Cultural Theory. Boulder, USA: Westview Press.

Toffler, A. (1970). Future Shock. New York: Random House.

Toffler, A. (1981). The Third Wave. New York: Bantam.

Traweek, S. (1988). Beamtimes and lifetimes: The world of high energy physicists.

Cambridge, MA: Harvard University Press.

Tversky, A., \& Kahneman, D. (1980). Causal Schemes in Judgements under Uncertainty. In M. Fishbein (Ed.), Progress in Social Psychology. Hillsdale, USA: Lawrence Erlbaum Associates.

Tversky, A., \& Kahneman, D. (1981). The Framing of Decisions and the Psychology of Choice. Science, 211, 453-458.

UNEP. (1997). Global Environmental Outlook. Oxford, UK: Oxford University Press.

van Vree, F. (1998). De scherven van de geschiedenis. Over crisisverschijnselen in de hedendaagse historische cultuur. Amsterdam: Vossiuspers AUP.

de Vries, G. (1995). De ontwikkeling van wetenschap. Groningen: Wolters-Noordhoff. VROM. (2000). Nota Mensen, Wensen, Wonen: Wonen in de 21ste Eeuw. Den Haag: Ministerie van Volkshuisvesting, Ruimtelijke Ordening en Milieu.

van Vught, F. A. (1985). De beleidsrelevantie van het moderne toekomstonderzoek. Beleid en Maatschappij, 1/2, 22-30.

van Vught, F. A. (1985). Beter dan Nostradamus en Campanella? Over de wetenschappelijke status van de sociaal-wetenschappelijke toekomstkunde (inaugurele rede). Leiden: Rijksuniversiteit Leiden.

Wells, H. G. (1902). The discovery of the future. Nature, 15(1684).

Wenger, E. (1998). Communities of practice: Learning, meaning and identity. Cambridge: Cambridge University Press.

de Wilde, R. (2000). De voorspellers: een kritiek op de toekomstindustrie. Amsterdam: Uitgeverij De Balie.

WNF. (1999). Levende rivieren. Zeist: Studie uitgevoerd door Stroming BV,

Hydrobiologisch Adviesbureau Klink b.v., Waterloopkundig Laboratorium, Landmeetkundig Bureau Meet. 
Wodak, R. (1996). Disorders of discourse. New York: Addison Wesley Longman Limited. Woolgar, S. (1988). Science: The very idea. Routledge / Ellis Horwood.

WRR. (2000). Terugblik op toekomstverkenningen. Den Haag: Stuurgroep

Toekomstonderzoek en strategisch omgevingsbeleid.

Yin, R. K. (1994). Case Study Research: Design and methods (2nd ed. Vol. 5). Thousand Oaks, California: Sage Publications.

\section{Aangehaalde (niet gepubliceerde) projectdocumenten RPB}

KUN (2001). 'Projectvoorstel: Scenario's voor de uitvoering van de Vijfde Nota Ruimtelijke Ordening'. 28 september 2001.

KUN (2001). 'Werkconferentie 'Scenario's voor de Vijfde Nota'. Eerste vragenlijst'. 21

november 2001.

KUN (2001). 'Werkconferentie 'Scenario's voor de Vijfde Nota'. Tweede vragenlijst'. 30 november 2001.

KUN (2001). 'Werkconferentie 'Scenario's voor de Vijfde Nota'. Derde vragenlijst'. 7 december 2001.

RPB (2003). 'Speerpunten van het Ruimtelijk Planbureau'. 7 april 2003.

RPB (2003). 'Vernieuwing van het Werkprogramma'. 7 april 2003.

RPB (2001). 'Scenario's voor de uitvoering van de Vijfde Nota: Plan van Aanpak'. 27 juli 2001.

SCENE (2001). 'Dynamische Scenario's'. 26 november 2001.

SCENE (2002). 'Indicatoren voor de Scenario's', 29 januari 2002.

VVR (2002). 'PVA Themaselectie VR 2003'. 13 maart 2002.

VVR (2002). 'Project Start Up 'Verkenning van Ruimte' op 1 en 2 juli 2002. Verslag'.

VRR (2002). 'Verkenning van Ruimte. Projectcontract'. 21 november 2002.

VVR (2002). 'Verkenning van Ruimte. Projectcontract. 26 november 2002.

VVR (2003). 'Notitie RasterPlan'. Augustus 2003.

VVR (2003). 'VVR Stand van Zaken'. Memo 17 september 2003.

WLO (2003). 'Onzeker naar 2040. Discussie'. 6 februari 2003.

WLO (2003). 'Welvaart en Leefomgeving. Plan van Aanpak voor een scenariostudie van vier planbureaus'. 21 augustus 2003.

WLO (2006). 'Concept Samenvatting van de WLO-studie'. 17 januari 2006. 
3

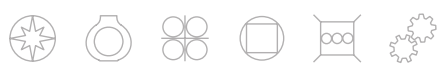




\section{Bijlage 1: \\ Overzicht van observatiemomenten}

\section{SCENE}

Datum

$09 / 11 / 2001$

$14 / 12 / 2001$

$16 / 01 / 2002$

18-22/03 2002

19/03/2002

20/03/2002

21/03/2002

21/03/2002

02/04/2002

09/04/2002

16/04/2002

21/05/2002

28/05/2002

$31 / 05 / 2002$

$08 / 07 / 2002$

$12 / 08 / 2002$

$08 / 10 / 2002$

20/11/2002
Bijeenkomst

Kennismaking met projectleider

Eerste werkconferentie

Tweede werkconferentie

Werkweek RPB

- Kerngroepsessie

- Kennismaking en discussie met ontwerpsters

- Deelgroepsessie NL in Europa

- Kennismaking en discussie met projectsecretaris

- Kerngroepsessie

Deelgroepsessie Stad \& Land

Deelgroepsessie Water

Kerngroepsessie

Kerngroep werksessie

Presentatie SCENE op SISWO door projectleider

Kerngroep evaluatiesessie

Evaluatiegesprek met projectleider

Lunchlezing VI-onderzoekers voor RPB

Telefonische conferentie met projectleider
Bijgewoond*

$\mathrm{M}$

S\&M

S\&M

S\&M

S\&M

S\&M

$\mathrm{S}$

S

S

S

S

S

$M$

S\&M

S\&M

S\&M

S\&M

S\&M

Bijgewoond

S\&M

$S \& M$

$S$

S\&M

$\mathrm{S}$

$\mathrm{S}$

S\&M

S\&M

S\&M

S

S\&M

S

S

S

26/03/2003

Voorbereiding perspectievendagen 
27/03/2003

07/04/2003

$10 / 04 / 2003$

$22 / 04 / 2003$

$28 / 04 / 2003$

$06 / 05 / 2003$

$08 / 05 / 2003$

$12 / 05 / 2003$

$15 / 05 / 2003$

$15 / 05 / 2003$

$12 / 06 / 2003$

$23 / 06 / 2003$

08/07/2003

$18 / 08 / 2003$

$19 / 08 / 2003$

20/08/2003

$21 / 08 / 2003$

$25 / 08 / 2003$

$25 / 08 / 2003$

$28 / 08 / 2003$

$02 / 10 / 2003$

09/10/2003

$13-16 / 10 / 2003$

$14 / 10 / 2003$

$14 / 10 / 2003$

$15 / 10 / 2003$

$11 / 12 / 2003$
Oefenpresentatie \& lunchlezing over VVR

Interne perspectievenworkshop deel 1

Interne perspectievenworkshop deel 2

Discussie tussen deelprojectleider Werken en ontwerper

over potentiekaarten

Schrijfteam

Strandsessie

Schrijfteam

Bijeenkomst Rasterplan

Projectteam

Schrijfteam

Schrijfteam en plenaire sessie met directeur RPB

Informele bijeenkomst met projectleider en

deelprojectleider Wonen

Schrijfteam

Ontwerpsessie Wonen

Ontwerpsessie Werken

Ontwerpsessie Landbouw

Ontwerpsessie Water

Sessie projectteam en directeur RPB

Discussie projectteam n.a.v. sessie met directeur RPB

Discussie over dummy boek

Eerste keer op het Willem Witsenplein

Discussie ontwerp

Observaties werkweek RPB 13-16 oktober

Onderzoeksberaad

Gesprek deelprojectleider Wonen met externe adviseur

Gesprek met directeur RPB n.a.v. Onderzoeksberaad

Presentatie boek in Nieuwspoort
S

S

S

$\mathrm{M}$

$S$

$S$

$S$

$S$

$S$

$S$

S\&M

$S$

$S$

$S$

S

$S$

$S$

$S$

$S$

$S$

$S$

$S$

$S$

$S$

\section{WELVAART EN LEEFOMGEVING (WLO)}

Datum

$24 / 10 / 2002$

$08 / 07 / 2003$

$21 / 08 / 2003$

$13 / 11 / 2003$

$13 / 11 / 2003$

23/03/2004

08/04/2004

14/04/2004
Bijeenkomst

\section{Bijgewoond}

$S \& M$

$S$

$S$

S\&M

$S \& M$

$S \& M$

$S \& M$

$\mathrm{M}$ 


\begin{tabular}{|c|c|c|}
\hline 15/04/2004 & Werkgroep Veiligheid & S \\
\hline 16/04/2004 & Werkgroep Natuur, Water \& Landbouw & S \\
\hline $11 / 05 / 2004$ & Regio + & S \\
\hline 13/05/2004 & Athena presentatie en Trekkersoverleg & M \\
\hline 01/06/2004 & Regio's + & M \\
\hline 08/06/2004 & Werkgroep Energie & S \\
\hline 22/06/2004 & Werkgroep Energie & S \\
\hline 23/06/2004 & Regio + & M \\
\hline 15/07/2004 & Workshop Ruimte in de WLO & S \\
\hline 10/08/2004 & Regio + & S \\
\hline 17/08/2004 & Trekkersoverleg & S \\
\hline 23/08/2004 & Regio + & S\&M \\
\hline 24/08/2004 & Werkgroep Energie & S \\
\hline 02/09/2004 & Werkgroep Natuur en Water & S \\
\hline 21/09/2004 & Regio + & S \\
\hline 19/10/2004 & Regio + & S\&M \\
\hline 10/11/2004 & Regio + & M \\
\hline 18/11/2004 & Integratiesessie & S\&M \\
\hline 23/11/2004 & Regio + & S \\
\hline 30/11/2004 & Trekkersoverleg & S \\
\hline 09/12/2004 & Werkgroep Natuur \& Water & S \\
\hline 14/12/2004 & Regio + & S \\
\hline 24/01/2005 & Trekkersoverleg & S \\
\hline 15/03/2005 & Trekkersoverleg & S \\
\hline 17/05/2005 & Presentatie WLO beleidsmakers & S\&M \\
\hline 18/06/2005 & Lunchlezing voortgang VI-onderzoek & S\&M \\
\hline 04/10/2005 & Trekkersoverleg & S \\
\hline 14/08/2006 & Presentatie Proefschrift coördinatoren WLO & S\&M \\
\hline 29/09/2006 & Boekpresentatie WLO & S \\
\hline
\end{tabular}

\section{OVERIG}

Datum

28/10/2002

$14 / 11 / 2002$

$10 / 12 / 2000$

$20 / 11 / 2002$

$11 / 02 / 2002$

$13 / 02 / 2002$

20/03/2002

$03 / 10 / 2002$

\section{Bijeenkomst}

Oefensessie spelsimulatie (Spel om de ruimte)

Spelsimulatie (1) Spel om de ruimte

Spelsimulatie (2) Spel om de ruimte

Telefonische conferentie Projectleider SCENE

Lezing RPB tijdens PM workshop ICIS

Lunchlezing 'Spel om de Ruimte' door projectleider

RPB-ateliers

Startconferentie RPB

\section{Bijgewoond}

S

$S$

M

S\&M

$S$

$S$

M

S\&M 
$20 / 03 / 2003$

Cursus projectmatig creëren deel 1 


\section{English summary}

How could we protect the Netherlands from floods and water damage if our climate continues to change? Where, how many houses, and what kind of houses should be built for the future? And do we need a railway connection between the North of the Netherlands and the Randstad area? Each of these complex policy issues asks for a long-term vision of the future.

In the Netherlands, there are many experts whose job it is to study the future ${ }^{59}$. Many of these professional futurists work at Dutch planning bureaus ${ }^{60}$. These planning bureaus are independent research institutes that, among others, provide the Dutch government with assessments of current and future developments. By assessing the long term, these futurists aim to support policy development in uncertainty and complexity. Over the years, a large number of such policy-oriented futures studies have appeared in which the future is explored.

Studying the future, however, seems a mission impossible. Resources to measure and obtain empirical data about past and present are limited and many relationships, that may seem to have developed continuously in retrospect, may follow non-linear patterns in the future. Since the system or processes under consideration can behave in different ways, both the appearance of the future and its underlying dynamics are unknown and unknowable. Studying the future is, therefore, not a matter of knowledge production in a classical sense. How do professional futurists accomplish what seems a mission impossible, how do they structure thinking and discussing the future, how do they balance between certainty and uncertainty, between probable and possible and between the known and the unknown? In this thesis I described and analysed how futurists study the future and, in doing so, produce future knowledge. By detailing the daily practice of professional futurists, I try to reveal the mechanisms and patterns active in / shaping the production of policy-oriented future knowledge.

\footnotetext{
59 There are many different 'futures studies'. Also prophecies, utopian narratives and 'science fiction' stories could be classified as futures studies. When I talk about futures studies I refer to exercises performed by professionals that are portrayed (by futurists and/or their public) as 'scientific'. In this thesis, I focus on policy-oriented futures studies, i.e. future exercises that aim to support policy development by (Dutch) policy makers.

60 There are four national planning bureaus in the Netherlands: the Netherlands Environment Assessment Agency (MNP), the Netherlands Bureau for Economic Policy Analysis (CPB), the Netherlands Institute for Spatial Research (RPB) and the Social and Cultural Planning Office of the Netherlands (SCP). These Planning Bureaus are part of national government but have a publication and research programme which does not require formal permission of a Minister.
} 


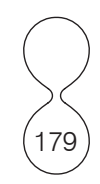

\section{Research approach}

One way to disclose the daily practice of professional futurists is to study practitioners while they are doing their work. Such in situ monitoring or "participant observation" is generally referred to as ethnography, which involves close attention, with some exactness, to the daily doings, deliberations and social processes in action. We ${ }^{61}$ did our ethnographic research among practitioners in actual future telling exercises ${ }^{62}$.

In the period 2001 - 2006, we followed three foresight exercises at the Netherlands Institute for Spatial Research (RPB). The RPB, one of the four Dutch planning bureaus, focuses on spatial planning, and in particular on developments in the fields of housing, commercial land use, mobility, urbanisation and landscape. By assessing the long term future, RPB aims to support the Dutch national government in the development of policies pertaining to spatial planning, natural resources, and quality of the landscape.

The RPB can be considered a particular site of future knowledge production. We witnessed different types of RPB's future telling exercises. Two exercises were referred to as "scenario projects", i.e. exercises in which professional futurists aim to develop alternative, equally legitimate stories about how the future may unfold. In one of these projects, i.e. the SCENE project, the futurists aimed to develop four qualitative descriptions of 2030 and the paths towards these futures. In the second scenario project, referred to as WLO, the futurists intended to employ extensive integrated modeling and quantitative analyses to illustrate four scenarios. The third project known as WV was explicitly not presented as a scenario exercise, but referred to as a "prognosis", in which the futurists did not intent to develop different possible stories about the future, but they focused on the question of what the most probable futures would be.

The first project, which we observed from November 2001 to May 2002, was the qualitative scenario project called SCENE, an acronym for A quartet spatial SCEnarios for the NEtherlands ${ }^{63}$. The final report appeared in May 2003. The objective was to explore the potential impact of a variety of societal developments on future land use. Four scenarios were developed for the Netherlands in 2030: the Netherlands as production space, the Netherlands as a natural environment, the Netherlands as experience space and the Netherlands as consumer space.

The second project was referred to by RPB as WR, a Dutch abbreviation for Exploration

\footnotetext{
${ }^{61}$ Prof. dir Marjolein van Asselt, supervisor and leader of the research program 'Perspectives on Uncertainty and Risk: A methodology program on toekomstverkenning' also actively participated in the ethnographic fieldwork (see appendix 1 for an overview of ethnographic 'moments').

62 In Dutch: 'Toekomstverkenning'.

${ }^{63}$ In Dutch: 'Een kwartet ruimtelijke scenario's voor Nederland'
}

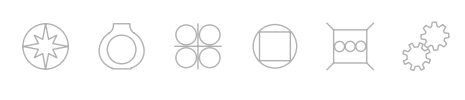


of Space ${ }^{64}$. The project started in June 2002 and finished in November 2003. The final report 'The unknown space explored', appeared in December 2003. This exercise was portrayed as a "prognosis" for the year 2040. The prognoses developed in this exercise were developed from quantitative extrapolative trend analysis on societal developments in the field of housing, commercial land use, agriculture and water. The futurists aimed to give special attention to uncertain developments that may change the course of observed trends in the past and present. These uncertain developments with a potential significant impact on land use were referred to as "signals". This project was furthermore characterised by the objective to integrate two cultures of foresight, i.e. research and design.

WLO, the other scenario exercise, started in January 2004 and was finished in July 2006. WLO was a Dutch abbreviation for The future of the Dutch natural and built environment ${ }^{65}$ and was a co-production of three Dutch national planning bureaus: the Netherlands Environment Assessment Agency (MNP), the Netherlands Bureau for Economic Policy Analysis (CPB), and the Netherlands Institute for Spatial Research (RPB). The futurists aimed to explore how various aspects of the living environment and land use in The Netherlands may develop. To that end, they performed analyses on a large number of societal topics, such as housing, commercial land use, traffic \& transport, energy, agriculture, nature \& landscape, water safety, and environment \& health. The study included extensive integrated modeling and quantitative analyses to support four scenarios in 2040: Strong Europe, Regional Communities, Global Economy and Transatlantic Market.

As we wanted to observe more than one future telling exercise, we choose not to immerse ourselves full time in the futurists' daily practice, but to select relevant ethnographic moments during the projects. We attended, audio recorded and transcribed many meetings. We talked to futurists and asked questions, both informally and in arranged open interview settings. We made notes on what we saw happening, on what we saw futurists doing and on what we heard them say, including non-verbal behaviour and monitored phone calls or bilateral chats. We collected documents that featured in the futurists' activities or that the futurists produced. We retrieved and received e-mails and took pictures. We also shared some observations with the futurists and recorded their feedback.

\footnotetext{
${ }^{64}$ In Dutch: 'Verkenning van de Ruimte'.

${ }^{65}$ In Dutch: 'Welvaart en Leefomgeving'.
} 


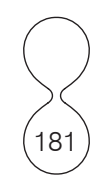

\section{Framework of the research}

I analysed the production of future knowledge by these professional futurists by looking at two ambitions that are often associated with policy-oriented futures studies and the way these ambitions worked out in practice: the variation and the integration ambition. The following line of argument motivates the variation ambition: since the future is uncertain, fundamentally different perspectives can be legitimate and should, therefore, be taken into account. Professional futurists pertaining to the variation ambition aim to describe a varied set of possible futures (= scenarios). The integration ambition, on the other hand, is the ambition to integrate different knowledge elements (sectors, themes and/or disciplines) in order to develop a more comprehensive view on the complexities of the future. This ambition is motivated by the conviction that the sum is more than the total of the parts.

By addressing these two ambitions, futurists aim to provide policy makers with more insight into the nature of critical uncertainties the complexities and to increase their adaptive and anticipative capacity. In SCENE the futurists emphasized the variation ambition in the first phase, and the integration ambition became more important in the latter phases of the endeavour. In WR, integration was the leading ambition in the process of future telling, although in the final report the variation ambition was foregrounded. The futurists in WLO aimed to address both the variation and the integration ambition.

Professional futurists who aim to address the variation and/or integration ambition, position themselves in a tradition of future telling, which is portrayed in futurist literature as 'new' or at least different. Their aim is not to predict the future - an ambition that they associate with the 'old' tradition', but to describe and picture uncertainty and complexity. In this thesis I described and analysed how professional futurists (try to) realise their 'new' ambitions. How do the variation and integration ambitions 'work' (out) in practice?

This thesis is structured as follows: first, I described how professional futurists (try to) realise the variation and integration ambitions. I observed that working with these ambitions is problematic in practice. Next, I tried to explain this problematic nature of future telling practice by distinguishing two competing temporal repertoires, i.e. a historical deterministic repertoire and a discontinuity repertoire. I showed that professional futurists are often not aware of the fundamental differences between the underlying perspectives on the 'knowability' of the future and, accordingly, the way future telling exercises should be carried out. I argued that if futurists do not acknowledge these conflicts, historical deterministic argumentations - that are at odds with the integration and variation ambitions - may actually prevail. I showed that if historical deterministic lines of argumentation become dominant, realising these ambitions becomes a mission impossible. 


\section{Summary of findings}

\section{Functional meanings}

Chapter three is a story about futurists who tried to establish variation of future descriptions by using the scenario matrix. In the literature, this future telling technique is often recommended as a tool to construct different images of the future in a coherent and systematic way. Also in many other Dutch future telling exercises futurists often use this "variation tool".

The two-by-two scenario matrix is both in the scenario literature and in practice often portrayed as a useful and straightforward tool to develop four different scenarios of the future. My observations in future telling practice, however, revealed that futurists attach fundamentally different meanings to this variation tool. In the SCENE project, three different what I proposed to refer to as "functional meanings" could be discerned: the matrix as skeleton, as foundation and as building scaffold. And each functional meaning, i.e. assumptions, logics, representations and functions ascribed to this ordering device, threw a different light on the variation ambition.

In the backbone functional meaning, the scenario matrix is considered as the frame representing the essential driving forces for the future and the four stories to be told. The backbone functional meaning prescribes how to do future telling: futurists study patterns and dynamics in order to discover the two most important driving forces. Once these are identified, they are to be plotted on two axes yielding four quadrants. The axes are read as a low-high dichotomy determining the four futures. Futurists pertaining to this scenario logic visualized the scenarios as a two-by-two matrix with four quadrants.

In the foundation functional meaning, the scenario matrix is not conceived as a two-by-two matrix yielding four possible futures, but as a two-dimensional space. The axes do not present a low-high dichotomy yielding four possible futures as in the backbone functional meaning, but they are portrayed as a continuum ranging from low to high allowing many possible futures. The axes are, foremost, considered a choice, a compromise or the upshot of a social process. The sense of the matrix itself is transformed: it multiplies the number of possible futures and it changes the relationship between the axes, i.e. the driving forces, and the scenarios, i.e. the futures told. The scenarios are still associated with the two axes, but the relationship is reversed. The quadrant, i.e. the position on the axes, doesn't determine the scenario narrative, but the scenario narrative determines the position on the axes. This representation violates the backbone functional meaning, but is unproblematic in case the scenario matrix is practised as foundation.

In the building scaffold functional meaning, the scenario matrix is not intrinsic to the 
futures (to be) told. Instead, it is considered a heuristic to advance variety between scenarios: useful to start up, but in a later phase will likely become an obstacle.

Discarding the scenario matrix is a precondition in the building scaffold logic: it is believed that removal is needed to enable futurists to develop complex and relevant scenarios. In this functional meaning the four scenarios are disconnected from the scenario matrix and the scenario matrix can, therefore, be removed: the futures told have a life of their own. This is a departure from both the backbone meaning, as this representation suggests irrelevance of the scenario matrix to the futures told.

Each of the functional meanings continued to be practiced and mobilised in the SCENE project. No closure with regard to functional meaning was established as none of the functional meanings was fully dismissed when alternative functional meanings were introduced. Our ethnography revealed the multiplicity of functional meanings associated with a variation tool referred to as standard in the futurists' community. In SCENE different interpretations of variation competed. There was, so to speak 'variation about variation', which made the realisation of the variation ambition very hard to realise.

\section{Cross-boundary objects and transformation of the overlapping territory}

In chapter four, I described how futurists in the WR project tried to implement the integration ambition. My observations made clear that the integration ambitions can mean different things to different people and in different phases of a future telling exercise. Futurists in the WR project referred to integration of sectors, themes, scale levels, disciplines, assumptions, time horizons, spatial claims, units of analysis and even of quantitative and qualitative insights. The way the WR futurists tried to do the integration ambition was to combine two different cultures of foresight, i.e. research and design. The researchers positioned themselves and were positioned as "analysts", "content experts" and those providing quantitative knowledge about probable futures. The designers portrayed themselves and were portrayed as those providing "imagination" and "creativity" and qualitative knowledge in terms of "desirability" and "possibility".

To describe the cooperation between researchers and designers in the WR project, I build upon an interdisciplinary body of literature, to which I refer as "boundary theory" (e.g. Callon (1986), Latour (1987; 1999), Star \& Griesemer (1989) en Clarke \& Fujimura (1992)). Boundary theory scholars try to explain cooperation between people from different social worlds. Star \& Griesemer (1989) introduced the notion of "boundary objects" to describe such collaboration. Boundary objects can be ideas, words, objects (documents, concepts, techniques) and processes that are both plastic enough to adapt to local needs and robust enough to maintain a common identity across sites. Due to this combination of plasticity and robustness, boundary objects can travel from one social domain to another and thereby creating an infrastructure that facilitates cooperation between 
people belonging to different social worlds. Because of quality to transcend boundaries, I considered cross-boundary object a more adequate description on the concept.

Also the WVR futurists tried to establish an infrastructure for cooperation. They did so by creating an "overlapping territory" between researchers and designers. In this overlapping territory, researchers and designers agreed to work together on the development of what I characterised as cross-boundary objects. However, despite hard work and good intentions, the futurists did not succeed in sustaining these cross-boundary objects. My analysis indicates that as a consequence they did not succeed in creating a solid infrastructure for interdisciplinary cooperation. Consequently, the integration ambition was unwillingly and unconsciously undermined. Even worse, boundary conflicts arose between researchers and designers. Futurists tried to solve these conflicts by moving the cross-boundary objects away from the overlapping territory of two disciplinary domains and by re-positioning them in either one of the cultural domains, i.e. they requalified them as either a research object or a design entity. Thereby, the infrastructure for cooperation, that never matured, was dismantled and the overlapping territory was depopulated. Instead of crossed, the borders between both domains were reinforced and reified. Consequently, the overlapping territory became a no mans land or 'no go area'. Eventually, the knowledge production process, in which integration model served as the original aspiration of the futurists, developed into a reality which is more in line with an alienation model. In the course of the project, design was increasingly subordinated and became a fringe culture. A clear hierarchy was created in which the researchers could play a leading role.

The loss of cross-boundary objects and the shift from collaboration to hierarchy radically undermined the integration of cultures and made implementation of the integration ambition actually impossible. I concluded that the concept of cross-boundary objects not only has analytical and explanatory value in studying successful interdisciplinary collaboration, but that it has equal value in understanding problematic courses of interaction between different cultures of future telling.

\section{Different temporal repertoires}

Analysing the production of future knowledge by professional futurists at the RPB demonstrated that it is difficult to 'do' integration and variation. I tried to explain this problem by distinguishing two competing temporal repertoires, in which past, present and future are connected in fundamental different ways (see table 1). Next I analysed how these two repertoires were mobilised by futurists in the WLO exercise. I observed how both repertoires mutually interacted and how this shaped the course of the future telling exercise. 
In the first repertoire, which I called the historical deterministic repertoire, the future is considered a 'probability space', i.e. a logical outcome of patterns and causal relations that can be observed in past and present. Starting points are the certainties of the past and temporal continuity. This repertoire is in accordance with the 'old' predictive ambition. In the second repertoire, that I called the discontinuity repertoire, futurists assume that the future can be fundamentally different from the past and present. Accordingly, they start from the uncertainties of the future and consider the future a 'possibility space' (compare Berkhout \& Hertin, 2002). In this repertoire, futurists do not aim to root assessments of the future in the past and present. The starting point for their production of future knowledge are the uncertainties of the future.

\begin{tabular}{|c|c|c|}
\hline & $\begin{array}{l}\text { Historical deterministic } \\
\text { repertoire }\end{array}$ & Discontinuity repertoire \\
\hline Starting points & $\begin{array}{l}\text { - Certainties of the past } \\
\text { - The future as probability space } \\
\text { - Temporal continuity } \\
\text { - Predicting }\end{array}$ & $\begin{array}{l}\text { - Uncertainties of the future } \\
\text { - The future as possibility space } \\
\text { - Deviations from past and } \\
\text { current patterns } \\
\text { - Exploring }\end{array}$ \\
\hline Future knowledge & $\begin{array}{l}\text { - Firmly rooted in past and } \\
\text { present (extrapolation) }\end{array}$ & $\begin{array}{l}\text { - Interpretations of uncertainties } \\
\text { (exploring different futures) }\end{array}$ \\
\hline Corresponds with & $\begin{array}{l}\text { - The forecast tradition } \\
\text { - The 'old' tradition' }\end{array}$ & $\begin{array}{l}\text { - The idea of scenario-analysis } \\
\text { - The 'new' tradition }\end{array}$ \\
\hline
\end{tabular}

Table 1 - Different temporal repertoires

In WLO, both repertoires were mobilised. However, the futurists did not explicitly acknowledge this co-existence, let alone the interference, of different temporal repertoires. As a result historical deterministic argumentations, which are at odds with the variation and integration ambition, got space to become increasingly important over the course of the foresight exercise.

Having understood the WLO endeavour in terms of co-existence and interference of two conflicting temporal repertoires, I decided to "revisit" SCENE and WVR. By analysing to what extent the different temporal repertoires could also explain some unproductive tensions and problematic contradictions in these future telling exercises, I aimed to understand better the troubles in implementing the variation and/or integration ambitions. 
In WR, the conflict between researchers and designers, and consequently the failing integration ambition, could indeed by understood as a conflict between two competing temporal repertoires. Researchers were the most important advocates of the historical deterministic perspective, while designers favoured the discontinuity perspective. At the start of the exercise, the futurists agreed that research and design should satisfy different criteria. In time, the future produced knowledge was increasingly evaluated in terms of historical deterministic criteria advanced by the researchers. Especially designers' assessments of the future were disqualified as not enough rooted in past and present. As the designers, who tried to go beyond assumptions of temporal continuity, were sidelined, the exercise eventually became a historical deterministic endeavour.

The manifestation of different temporal repertoires in future telling exercises could also explain some of the tensions that were caused by unresolved discussions about the use and presentation of the scenario matrix. I argued that the backbone functional meaning of the scenario matrix corresponded with the historical deterministic line of reasoning. Although the disputes in SCENE were primarily between proponents of the foundation and building scaffold functional meaning, some of the futurists also continued to refer to the scenario matrix as a backbone. The 'stickiness' of this functional meaning through the scenario exercise can be explained by the attractiveness of the historical deterministic repertoire to some futurists. As a result of the coexistence of two temporal repertoires, 'variation over variation' remained.

\section{Switching ambitions}

Observing the daily practice of professional futurists showed that implementing the integration and variation ambition was problematic in each of the three RPB future telling exercises. In SCENE the so-called 'variation over variation' threatened the process as no consensus could be reached on the presentation of the scenario axes in the final reports. In WR the integration ambition failed, the futurists involved in this project were even about to withdraw from the project and many changes took place in the project team as a way to move forward. In WLO, the range of scenarios was seriously narrowed by the unfolding dominance of the historical deterministic repertoire. Nevertheless, the futurists managed to finalise these projects in terms of producing three reports.

I argued that futurists overcame deadlocks and seemingly irreconcilable differences by switching between the integration and variation ambition. That is, in cases where the variation ambition stranded, the futurists mobilised or emphasized the integration ambition over the variation ambition and vice versa. By switching ambitions, futurists can still position themselves within the 'new' tradition of future telling, in which uncertainty and complexity are key motives. By switching ambitions, the futurists played a so-called paradox game (e.g. Bal, Bijker \& Hendriks, 2002) in which the practice (backstage) is 
presented fundamentally different front stage. Some of backstage practice can actually be characterised as corresponding to the "old" forecasting tradition, in which historical deterministic thinking and acting dominates. In the front stage portrayals, however, the process and the produced future knowledge were presented as part of a "new" tradition, which is more in line with the discontinuity temporal repertoire.

\section{Conclusion}

Professional futurists are confronted with unproductive tensions and problematic contradictions while producing future knowledge. Ongoing awareness of conflicting and competing temporal repertoires and how they may manifest themselves (multiple functional meanings, boundary conflicts), while producing future knowledge, seems needed.

If professional futurists, despite their ambitions, are unable to go beyond historical deterministic lines of argumentations, it seems more appropriate to acknowledge that there is more continuity between their practice and the "old" forecasting tradition. Another option would be to embrace the new ambitions more actively and really start reasoning from the uncertainties and complexities of the future. This means using the past as springboard, and no longer as hammock. Especially in times of critical uncertainties and major complexity, this challenging route asks to be explored.

By detailing mechanisms and interplays which are active in current future telling practice, I aimed to provide insights as well as vocabulary which hopefully help futurists to further explore how to implement the variation and/or integration ambitions. In so doing, I hope that the stories on RPB future telling endeavours serve as learning opportunities, not only for RPB futurists, but for everyone involved in the study of the future, whether in the production or the use of future studies.

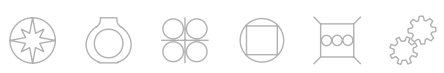




\section{Curriculum Vitae Susan van ‘t Klooster}

Susan van 't Klooster (1975) studeerde Cultuur- en Wetenschapsstudies (CWS) aan de Universiteit Maastricht. Een aantal vakken volgde zij aan 'Queen's University of Belfast' in Noord-lerland. Tijdens een stage bij het International Centre for Integrative Studies (ICIS) aan de Universiteit van Maastricht in het laatste jaar van haar studie, kwam zij voor het eerst in aanraking met het fenomeen 'toekomstverkenning'.

Na haar afstuderen in 2000 werkte zij als onderzoeker bij het ICIS op verschillende toekomstverkennende studies. Deze projecten waren gericht op lange termijn visievorming en strategieontwikkeling ten behoeve van watermanagement in Nederland. In deze periode was zij ook lid van een team jonge onderzoekers dat als inzending voor een wedstrijd over de toekomst van Nederland (georganiseerd door de CUR), een gezelschapsspel ontwikkeld heeft, dat gericht was op het ondersteunen van beleidsmakers en andere belanghebbenden in het ontwikkelen van lange termijn (beleids)strategieën.

In 2002 begon Susan aan haar promotieonderzoek bij de Faculteit der Cultuurwetenschappen en de vakgroep Maatschappijwetenschap en Techniek aan de Universiteit van Maastricht. Tijdens haar promotie volgde zij het tweejarige opleidingsprogramma voor promovendi van de onderzoeksschool voor Wetenschap, Technologie en Moderne Cultuur (WTMC). Tijdens haar promotieonderzoek was zij niet meer onderzoeker in, maar werd zij onderzoeker van verschillende toekomstverkennende studies. Naast haar onderzoekswerkzaamheden was zij 'tutor' en 'skillstrainer' bij de opleiding European Studies aan de Faculteit der Cultuurwetenschappen van de Universiteit Maastricht. In de zomer van 2005 was zij gastonderzoeker bij prof. Susan Leigh Star en prof. Geoffrey Bowker aan het Institute of Science, Technology and Society (STS) (Santa Clara University) in Californië.

Sinds 1 oktober 2006 werkt Susan als onderzoeker bij het Instituut voor Milieuvraagstukken (IVM) aan de Vrije Universiteit (VU) in Amsterdam. Zij doet daar onderzoek naar methodologie van toekomstverkenning en ontwikkelt momenteel in een interdisciplinair onderzoeksteam een discussieondersteunend systeem waarin verschillende veiligheidsstrategieën kunnen worden geëvalueerd voor een klimaatbestendig Nederland. Daarnaast is zij als onderzoeker betrokken bij diverse advies- en onderzoeksprojecten op het gebied van publieke participatie en is zij projectleider van het project 'Burgerpanel Utrecht: participatie van burgers bij het Waterplan Utrecht'. Vanaf september 2007 zal Susan zitting nemen in de redactie van Toekomstverkenning Online: een onafhankelijke site waarin informatie wordt verstrekt over toekomstonderzoek (www.toekomstverkenning.nl). 


\section{Publicatieoverzicht}

\section{Artikelen}

van 't Klooster, S.A., van Asselt, M.B.A., en Koenis, S. (2002). Beyond the essential contestation: construction and deconstruction of regional identity, Ethics, Place and Environment, 5:2 (109-121).

van Asselt, M.B.A., van 't Klooster, S.A., en van Notten, Ph.W.F. (2003). Verkennen in onzekerheid. Beleid en Maatschappij - Themanummer Toekomstscenario's en beleid, 30 (230-241).

Middelkoop, H., van Asselt, M.B.A., van 't Klooster, S.A., van Deursen, W.P.A., Kwadijk, J.C.J., en Buiteveld, H. (2004). Perspectives on flood management in the Rhine and Meuse rivers, River Research and Applications, 20 (327-342).

van 't Klooster, S.A. en van Asselt, M.B.A (2006). Practising the scenario-axes technique. Futures, 38:1 (15-30).

van Asselt, M.B.A. en van 't Klooster, S.A. (2007). Toekomstscenario's: een kijkje achter de schermen, Nederlands Tijdschrift voor Medische Microbiologie, themanummer 'Toekomstscenario's' (2007).

van Asselt, M.B.A., Mesman, J. en van 't Klooster, S.A. (2007). Dealing with prognostic uncertainty, Futures, 39:6 (2007).

van Asselt, M.B.A., Mesman, J. en van 't Klooster, S.A. (in voorbereiding). Uncertainty manners: Ethnographic insight in the practice of foresight.

van 't Klooster, S.A. en van Asselt, M.B.A. (in voorbereiding). 'Time', 'the future' and temporal repertoires in futures studies.

\section{Hoofdstukken}

Carton, L., Karstens, S., Rozemeijer, M., van Asselt, M.B.A., Goosen, H., Greeuw, S. Haasnoot, M., van 't Klooster, S.A., Ruijgrok, E., Tanczos, I., Valkering, E., Visser, P. (2002). The W4R Game: Exploring the future consequences of water management. In: Mayer, I. en Veeneman, W. (eds.), Games in a World of Infrastructures. Simulation-games for Research, Learning and Intervention. (85105). Eburon, Delft.

van Asselt, M.B.A., Huijs, S., en van 't Klooster, S.A. (2003). The intriguing relationship between uncertainty and normativity: The need for pluralistic assessment. In: Gottschalk-Mazouz, N. en Mazouz, N (eds.), Nachhaltigkeit und globaler Wandel. Integrative Forschung zwischen Normativität und Unsicherheit (61-86). Campus, University of Stuttgart, Germany.

van 't Klooster, S.A. (2003). Een pleidooi voor herwaardering van de pre-socratische tragische cultuur. In: van Asselt, M.B.A. en Petersen, A.C. (eds.), Niet bang voor onzekerheid, (51-61), RMNO/Lemma, Den Haag. 


\section{Onderzoeksrapporten}

van Asselt, M.B.A., Middelkoop, H., van 't Klooster, S.A., van Deursen, W.P.A., Haasnoot, M. Kwadijk, J.C.J., Buiteveld, H., Können, G.P., Rotmans, J., van Gemert, N., en Valkering, P. (2001). Development of flood management strategies for the Rhine and Meuse basins in the context of integrated river management. NRCpublication 16-2001. IRMA-SPONGE project 3/NL/1/164/99 1518301.

van Asselt, M.B.A., Middelkoop, H., van 't Klooster, S.A., van Deursen, W.P.A., Haasnoot, M. Kwadijk, J.C.J., Buiteveld, H., Können, G.P., Rotmans, J., van Gemert, N., en Valkering, P. (2001). Integrated water management strategies for the Rhine and Meuse basins in a changing environment. Final Report of the NRP-project 958273, Maastricht/Utrecht.

Medewerking aan de discussienotitie in het kader van het Vernieuwingsimpulsprogramma "'Perspectives on Uncertainty and Risk: An interdisciplinary methodology program on Toekomstverkenning", juni 2003.

Medewerking aan het onderzoeksrapport: "De toekomst Begint Vandaag: Inventarisatie Toekomstverkenningen" en het beleidsrapport "Houdbaarheid verstreken: Toekomstverkenning en beleid", beiden in opdracht van het Ministerie van Binnenlandse Zaken en Koninkrijksrelaties, april 2005. 


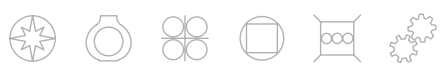

